\title{
EMPRESAS FAMILIARES \\ DA REGIÃO NORTE \\ MAPEAMENTO, RETRATOS E TESTEMUNHOS
}

\section{Ana Paula Marques}

Roadmap para

Empresas Familiares

Portuguesas 


\section{TÍTULO}

Empresas Familiares da Região Norte. Mapeamento, Retratos e Testemunhos

\section{COORDENAÇ̃̃O}

Ana Paula Marques

\section{COLABORAÇÃO}

Ana Isabel Couto

António Nogueira da Costa

José Machado Cunha

Paula Freire

Paula Silvestre

Sílvia Jorge

Shital Jayantilal

\section{ENTIDADES PROMOTORAS}

Centro Interdisciplinar de Ciências Sociais (CICS.NOVA) - Polo da Universidade do Minho (UM) Associação Empresarial de Portugal (AEP)

\section{PROJETO}

Roadmap para Empresas Familiares Portuguesas (NORTE-02-0853-FEDER-000018)

IMPRESSÃO

Gráfica do Diário do Minho

TIRAGEM

1000 exemplares

ISBN

978-989-20-8693-4

DOI

\section{DEPÓSITO LEGAL}

Setembro 2018 


\section{Índice}

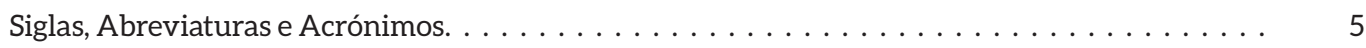

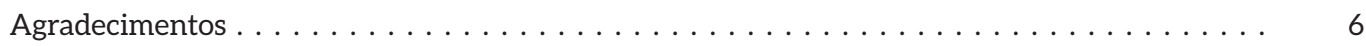

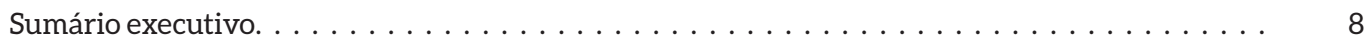

Introdução $\ldots \ldots \ldots \ldots \ldots \ldots \ldots \ldots \ldots \ldots \ldots \ldots \ldots \ldots \ldots$

\section{Parte}

Projeto "Roadmap para Empresas Familiares Portuguesas" . . . . . . . . . . . . . 12

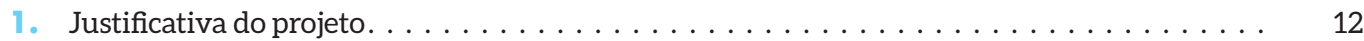

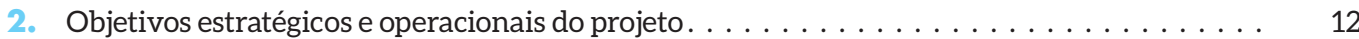

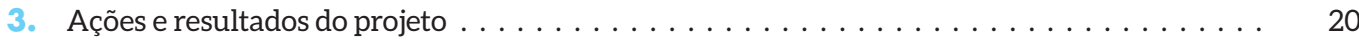

4. Roteiro metodológico. . . . . . . . . . . . . . . . . . . . . . . . . . . . . . 27

4. 1. Enfoque quantitativo - Mapeamento e retratos das EFs . . . . . . . . . . . . . 28

4.1.1. Estabilização do conceito "Empresa Familiar". . . . . . . . . . . . . . . . 28

4.1.2. BD Roadmapef . . . . . . . . . . . . . . . . . . . . . . 30

4.1.3. Questionário EFs região Norte . . . . . . . . . . . . . . 31

4.2. Enfoque qualitativo - Testemunhos de empresário(a)s . . . . . . . . . . . . . 36

4.3. Enfoque participativo - (Auto) Reflexividade . . . . . . . . . . . . . . . . . . 37

\section{Parte}

Mapeamento, retratos e testemunhos das EFs da Região Norte . . . . . . . . . . . . 39

1. Mapeamento das EFs. . . . . . . . . . . . . . . . . . . . . . . . . . . . . 39

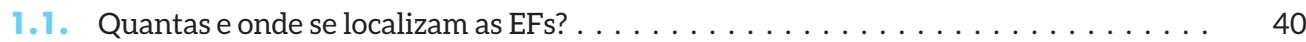

1.2. Qual a dimensão das EFs por número de trabalhadores?. . . . . . . . . . . . . . . 48

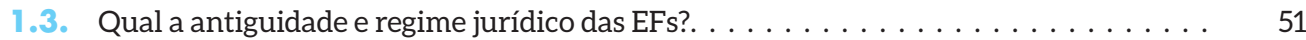

1.4. Em que atividades económicas as EFs são mais relevantes? . . . . . . . . . . . . . . 58

1.5. Quanto faturam e qual o peso da exportação das EFs? . . . . . . . . . . . . . . 60 


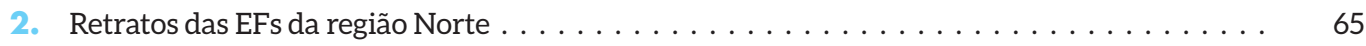

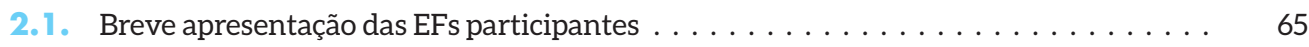

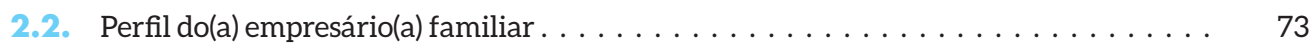

2.3. Recursos financeiros e internacionalização . . . . . . . . . . . . . . . . 79

2.4. Inovação, qualidade e preservação ambiental . . . . . . . . . . . . . . 88

2.5. Recursos humanos, formação e avaliação. . . . . . . . . . . . . . . . . 97

2.6. Governação e profissionalização da Empresa Familiar . . . . . . . . . . . . . . . 105

2.6.1. Papel do(a) fundador(a) . . . . . . . . . . . . . . . . . 105

2.6.2. Estrutura de governação . . . . . . . . . . . . . . . . 111

2.6.3. Preparação da "nova" geração. . . . . . . . . . . . . . . . . 116

2.6.4. Fatores de sucesso (e críticos) da empresa familiar. . . . . . . . . . . . . 122

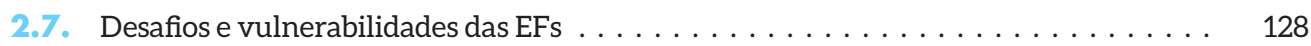

3. Testemunhos e singularidades de empresário(a)s . . . . . . . . . . . . . . . 133

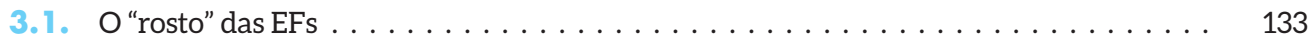

3.2. Passado, presente e futuro das EFs . . . . . . . . . . . . . . . . 134

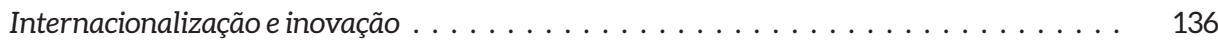

Diferenciação, inovação e economia digital. . . . . . . . . . . . . . . . 138

Autofinanciamento e controlo patrimonial . . . . . . . . . . . . . . . . 139

Visão e missão do(a) fundador(a): o "espírito empreendedor" . . . . . . . . . . . . . . . 140

"Honrar a família": orgulho, lealdade, compromisso e confiança . . . . . . . . . . . . . 142

Qualificar os membros familiares. . . . . . . . . . . . . . . . . . . . 143

(In)formalidade das decisões e planeamento . . . . . . . . . . . . . . . . 145

Manutenção do negócio nas "mãos" da família . . . . . . . . . . . . . . . . . . . . 147

Naturalização e adiamento da sucessão familiar . . . . . . . . . . . . . . . . . . . . . 148

Liderar no feminino. . . . . . . . . . . . . . . . . . . . 150

Conciliação (difícil) da vida familiar com a empresa . . . . . . . . . . . . . . . . 151

Descentralizar, desburocratizar e legislar. . . . . . . . . . . . . . . 153

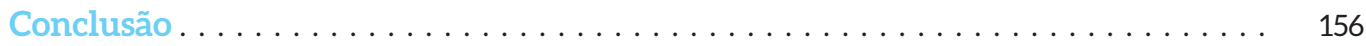

Bibliografia. . . . . . . . . . . . . . . . . . . . . . . . . 157 


\title{
SICLAS, ABREVIATURAS E ACRÓNIMOS
}

\author{
AEP - Associação Empresarial de Portugal \\ CAE - Classificação das Atividades Económicas
}

CICS.UMinho - Centro Interdisciplinar de Ciências Sociais - Polo Universidade do Minho

COM - Comissão Europeia

EC - European Commission

EF - Empresa Familiar

FEDER - Fundo Europeu de Desenvolvimento Regional

GEM - Global Entrepreneurship Monitor

I\&D - Inovação \& Desenvolvimento

ICS - Instituto de Ciências Sociais

IES - Informação Empresarial Simplificada

IFERA - International Family Enterprise Research Academy

INE - Instituto Nacional de Estatística

LASICS - Laboratório de Sistemas de Informação para a Investigação em Ciências Sociais NUTS - Nomenclatura de Unidades Territoriais para Fins Estatísticos

PAC - Plataforma das Artes e Criatividade

PIB - Produto Interno Bruto

PME - Pequenas e Médias Empresas

PORDATA - Base de Dados Portugal Contemporâneo

SICAE - Sistema de Informação da Classificação Portuguesa das Atividades Económicas

SWOT - Strengths, Weaknesses, Opportunities, Threats, ou, em português, Forças, Fraquezas, Oportunidades e Ameaças

TIC - Tecnologias das Informação e Comunicação

UE - União Europeia

UM - Universidade do Minho 


\section{AGRADECIMENTOS}

A equipa responsável pelo desenvolvimento do projeto "Roadmap para Empresas Familiares Portuguesas" agradece a todos os que permitiram esta iniciativa, em especial aos membros de famílias empresárias que dispensaram o seu tempo na participação deste estudo. Estes permitiram concretizar o primeiro desígnio do projeto: o de mapear as empresas familiares no Norte, saber quantas são, onde se localizam e qual o seu contributo para a economia e sociedade. Esta base de dados, exclusivamente constituída por empresas familiares da região Norte, é pioneira e inovadora em Portugal.

Não sendo possível nomear as quase mil e duzentas empresas familiares que diretamente preencheram o questionário online e presencial, resta-nos deixar publicamente um agradecimento muito especial à sua participação neste projeto. Igualmente, um bem-haja aos 23 empresário(a)s entrevistado(a)s que recuperam o passado, fizeram balanços e projetaram os desafios futuros das suas empresas familiares.

Importa destacar, também, a abertura e a disponibilidade de associações empresariais e locais, autarquias, especialistas e quadros técnicos, mobilizando contactos e redes de aproximação às empresas familiares, indispensáveis à realização de um ciclo de 8 workshops pelas NUTS III da região Norte. Com eles, potenciaram-se dinâmicas coletivas de partilha e discussão de tópicos internos às empresas familiares, com destaque para a sinalização de preocupações e desafios comuns na atuação em mercados competitivos globais e locais.

Uma palavra final de apreço para todos os consultores e o apoio técnico especializado envolvidos neste estudo, fundamentais para a concretização das funções quer de foro científico, quer de tratamento quantitativo e qualitativo da informação recolhida de importância fundamental para a preparação do presente estudo.

Este projeto foi financiado pelo Programa NORTE 2020 e FEDER (NORTE-02-0853-FEDER-000018) e insere-se no Eixo Prioritário - Sistema de apoio às ações coletivas - "Qualificação", com o Objetivo Temático: "Reforçar a competitividade das pequenas e médias empresas". 


\section{SUMÁRIO EXECUTIVO}

\section{Justificativa do projeto}

Mapear as Empresas Familiares (EFs) é de importância crucial para Portugal e Europa. As EFs são a tipologia empresarial dominante e contribuem significativamente para o produto nacional bruto e criação de emprego. Assumem uma importância estratégica pela socialização para a iniciativa, o risco e a capacidade de identificação de potenciais áreas de negócio. São também relevantes para a coesão territorial de qualquer comunidade local pela sua durabilidade e ligação histórica do(a) fundador(a) da mesma. Não obstante, refira-se a ausência de conhecimento exaustivo e de investigação consistente sobre este perfil de empresa e sua relativa invisibilidade, com particular destaque para os fatores de internacionalização e profissionalização na economia global.

São várias as razões que sustentam o estudo de EFs em Portugal, designadamente:

- estima-se que as EFs sejam entre $70 \%$ a $80 \%$ das empresas nacionais, absorvam $50 \%$ da força de trabalho e contribuam para $2 / 3$ do PIB;

- apresentam diversos perfis em função da dimensão, setores de atividade, antiguidade, mercados de exportação, grau de profissionalização e governo;

- potenciam a identificação de novas oportunidades de inovação (e.g. start-ups e iniciativas empreendedoras) e transmissão de conhecimento numa perspetiva intergeracional e de longo prazo (passagem do conhecimento e "segredo" do negócio entre gerações);

- $\quad$ são portadoras de um "legado" e "rosto", com capacidade de atração e fixação de recursos humanos e desenvolvimento de comunidades locais, em especial em zonas geográficas fora dos grandes centros.

O projeto "Roadmap para Empresas Familiares Portuguesas" (NORTE-02-0853-FEDER-000018), liderado pela Universidade do Minho, em co-promoção com a AEP, prossegue o duplo objetivo de mapear as empresas familiares da região Norte e avaliar o seu contributo para a economia local, nacional e internacional. Visa saber quantas são as empresas de cariz familiar existentes e quais as principais características que as distinguem de empresas não familiares.

Estrutura-se a partir de 4 ações principais:

1) construção de uma base de dados de empresas familiares da região Norte;

2) elaboração e aplicação de um questionário online e presencial dirigido a uma amostra de EFs, acompanhado de entrevistas aprofundadas a famílias empresárias;

3) disseminação e divulgação da informação, através de um website oficial do projeto (www.roadmapef.ics.uminho.pt); 
4) organização de workshops e seminários, com a participação direta das EFs.

Destaque-se o potencial de spillover deste projeto, com a possibilidade de alargamento a outras regiões do país, conferindo escala e protagonismo das EFs enquanto ator coletivo crucial na dinâmica económica, tecnológica e de criação de emprego.

\section{Base dados Roadmapef da região Norte}

Para a sua concretização, parte-se da definição de empresas familiares avançada pelo Grupo de Peritos criado pela Comissão Europeia. Uma empresa, qualquer que seja a sua dimensão, é uma Empresa Familiar, se: i) "a maioria dos direitos de voto for detida pela(s)or pessoa(s) singular(es) que estabeleceu(eram) a empresa, pela(s) pessoa(s) singular(es) que tiver(erem) adquirido o capital social da empresa, ou na posse dos seus cônjuges, pais, filhos ou herdeiros diretos dos filhos; ii) a maioria dos direitos de voto pode ser direta ou indireta; iii) pelo menos um representante da família ou parente consanguíneo estiver envolvido na gestão ou administração da empresa; iv) as sociedades cotadas incluem-se na definição de Empresa Familiar se a pessoa que estabeleceu ou adquiriu a empresa (capital social) ou as famílias desta, ou seus descendentes, possuem $25 \%$ dos direitos de voto correspondentes ao respetivo capital social." (UE, 2009, s.p.).

Trata-se de um estudo pioneiro e inovador em Portugal, que conjuga a vertente de mapeamento das empresas familiares na região Norte com a caraterização e aprofundamento junto de uma amostra de famílias empresárias.

Neste mapeamento, obteve-se a Base dados Roadmapef, com o registo de 41.496 entidades empresariais, que representa cerca de $10,4 \%$ das empresas classificadas pelo INE na região. As principais conclusões deste mapeamento apontam-nos para tendências de:

- Litoralização das empresas: mais de metade das EFs localiza-se na Área Metropolitana do Porto, seguida, com pesos relativos substancialmente mais reduzidos, pelas NUTS Cávado, Ave, Tầmega e Sousa e Alto Minho e, com menor expressão, Douro, Terras de Trás-os-Montes e Alto Tâmega;

- Predomínio de micro empresas (até 9 trabalhadores) (70,7\%), porém assinale-se também a presença de pequenas, médias e grandes empresas familiares que são cerca de 4 a 5 vezes mais em número quando comparadas com as empresas não familiares da região Norte;

- Proporção de mão-de-obra feminina mais significativa nas empresas de maior dimensão, por oposição às micro e pequenas empresas;

Antiguidade predominante de EFs com menos de 20 anos (previsível coexistência das $1^{\text {a }}$ e $2^{\mathrm{a}}$ gerações), apesar de se registar uma proporção significativa de EFs com 20 a 50 anos, incluindo, mais de 50 anos de existência, o que denota a maior resiliência e longevidade desta tipologia empresarial face ao cômputo geral das empresas;

- Posse do estatuto jurídico de sociedades por quotas, em linha com o que acontece para as empresas em geral, não sendo despicienda a presença de sociedade anónima, empresário em nome individual e sociedade unipessoal por quotas; 
- Presença mais expressiva das EFs nos setores de comércio por grosso e a retalho, indústrias transformadoras, construção, atividades de consultoria e alojamento;

- Volumes de negócio localizados principalmente nos intervalos inferiores a um milhão de euros, em especial no de menos de $250.000 €$ (sobretudo para as micro e pequenas empresas);

- Apenas $26 \%$ das EFs do Norte investem em mercados além-fronteiras, revelando a internacionalização como um desafio crítico para a competitividade na economia global.

\section{Retratos das empresas familiares participantes}

Aplicação de um questionário (online e presencial) a uma amostra robusta constituída por 1.148 EFs que integram a Base dados Roadmapef, que é estatisticamente representativa do universo-alvo por NUTS III e dimensão, com um nível de confiança de $95 \%$ e um erro máximo de $3 \%$.

A recolha da informação orienta-se para as seguintes secções alvo de aprofundamento na análise dos resultados: características das empresas familiares; perfil do(a) empresário(a); financiamento e internacionalização; inovação, qualidade e preservação ambiental; recursos humanos, formação e avaliação; estrutura de governação, nomeadamente papel do(a) fundador(a), mecanismos de governo, preparação da sucessão e fatores de sucesso (e críticos) da EF; e desafios e vulnerabilidades específicas deste tipo de empresas.

\section{Características das empresas familiares participantes}

- Quase metade delas localiza-se na Área Metropolitana do Porto. São relativamente jovens, com menos de 20 anos de existência, ainda que quase um terço delas tenha entre 20 a 50 anos, pelo que é expectável que a figura do(a) atual fundador(a) se confunda com a de proprietário(a);

- São sobretudo micro e pequenas empresas, constituídas como sociedades por quotas, não obstante um terço delas assumir a figura de empresário em nome individual;

- A área de negócio focaliza-se, em especial, no comércio por grosso e a retalho, na indústria transformadora e nos serviços/ consultoria, incluindo o setor de turismo e informática. No setor da indústria transformadora, as empresas de maior dimensão e mais antigas são mais expressivas, ao passo que as mais recentes e tendencialmente mais pequenas se distribuem pelo leque setorial mais alargado de atividades económicas atrás referenciado.

\section{O perfil do(a) empresário(a) participante}

Empresário predominantemente masculino, com idade média localizada nos 47 anos, e habilitações literárias igual ou superior ao ensino secundário. As empresárias possuem níveis de escolaridade superiores, quando comparadas com os seus homólogos, e têm uma idade média inferior (41 anos). Ambos tendem a ocupar maioritariamente posições de gerente/proprietário, ainda que de forma mais expressiva para os homens, bem como 
tendem a estar há mais anos à frente da empresa.

\section{Financiamento e internacionalização das EFs participantes}

- O autofinanciamento e o recurso à banca são as principais fontes de financiamento das empresas familiares, embora quase um terço delas tenha de recorrer a fundos familiares, em especial as empresas de reduzidíssima dimensão e nos primeiros de existência;

- Os produtos ou serviços das empresas familiares estão orientadas para todos os tipos de mercado, seja o mercado local/regional, seja apenas o mercado nacional, ou mercado nacional combinado com o internacional. $O$ peso das exportações relaciona-se diretamente com a dimensão da empresa: em média, as micro empresas são as que apresentam um menor volume de exportações, situando-se entre os $30 \%$ e os $35 \%$, seguindo-se as pequenas empresas, as quais ultrapassam os $40 \%$, e, por fim, as maiores empresas que se aproximam dos $60 \%$.

\section{Inovação, qualidade e preservação ambiental prosseguidas pelas EFs participantes}

$11,2 \%$ delas declaram possuir um departamento/núcleo de investigação e desenvolvimento (I\&D), estando dependente da dimensão da empresa;

- $16,3 \%$ encontra(ra)m-se envolvidas num processo de inovação nos últimos três anos de atividade empresarial;
- Deste esforço da inovação, apenas 22,5\% procederam ao registo de propriedade intelectual (traduzido em patentes, desenhos ou modelos, direitos de autor, etc.);

- $27,4 \%$ possuem certificação de qualidade, sendo sobretudo uma caraterística das empresas de maior dimensão;

- As políticas de preservação ambiental, tais como reciclagem do material, tratamento de resíduos e dos recursos que consomem, preservação ambiental na produção e distribuição dos produtos/serviços, são profusamente seguidas pelas empresas, sendo relativamente independentes da dimensão e antiguidade das EFs.

\section{Recursos humanos, formação e avaliação das EFs participantes}

- Na análise da evolução da criação de emprego nos últimos três anos, somente $9,3 \%$ das empresas diminuíram o número de trabalhadores, enquanto $47,8 \%$ estabilizaram e 42,9\% aumentaram;

Entre os novos trabalhadores recrutados no último ano, as empresas procuraram sobretudo trabalhadores com experiência profissional, independentemente da idade; todavia, também foram procurados jovens com qualificações técnico-profissionais ajustadas ao negócio da empresa e com qualificações académicas superiores.

Apenas 22,8\% das empresas possuem um plano formal de avaliação do desempenho dos trabalhadores, sobretudo as de maiores dimensões; 
- Entre as empresas que possuem um plano formal de avaliação do desempenho dos trabalhadores, são valorizados critérios como produtividade, pontualidade/assiduidade e cumprimento dos objetivos definidos para a função/cargo;

As consequências decorrentes dessa avaliação apontam principalmente para a atribuição de prémios de produtividade e aumento/promoção salarial.

\section{Estrutura de governação, papel do(a) fundador(a), preparação da sucessão e fatores de sucesso (e críticos) das EFs participantes.}

Não existem mecanismos de governance que sejam universais e aplicáveis de forma idêntica a todas EFs. A sua estrutura de governance pode ser uma forma de conseguir alavancar a vantagem competitiva face à concorrência, salvaguardando-a de eventuais conflitos e protegendo a harmonia no seio familiar. Este equilíbrio é cada vez mais importante, pois protege a família e assegura a continuidade da empresa. Isto implica definir a separação entre as duas dimensões, com a introdução de processos formais que determinem com clareza como a família irá se relacionar com a empresa, como também definir quando, e em que medida, a família é informada sobre o que se passa no âmbito da empresa familiar.

\section{Papel do(a) fundador(a)}

- O(a) atual responsável da empresa foi o(a) respetivo(a) fundador(a) em $61,9 \%$ das empresas;
- Razões de oportunidade de negócio e necessidade de criar o próprio emprego na base da criação da empresa familiar;

- Presença maioritária da primeira geração à frente e assumindo funções na empresa, não obstante quase um terço fazer parte já da $2^{\mathrm{a}}$ geração;

- Concretização de um projeto de autonomização profissional e económica, por um lado, e, por outro, exposição a um processo de socialização precoce em idades jovens favorecem a sucessão e permitem ancorar a compreensão mútua entre os membros da família e o(a) fundador(a).

\section{Estrutura de governance da empresa}

- Capital social das empresas familiares é detido maioritariamente por membros familiares (94,3\%), independentemente da dimensão e antiguidade da empresa;

Ausência de participações de membros não familiares ultrapassa os $90 \%$ dos casos, indiciando um comportamento de reserva, a par de se privilegiar sobretudo relações de parentesco consanguíneo na sua estrutura de governo;

- Maior permeabilidade da presença de mulheres com laços de parentescos na gerência explicável, em grande parte, pelo papel de proprietária/ acionista, ainda que uma proporção significativa mantenha já funções de gestão ou direção. 


\section{Preparação da "nova" sucessão}

- Em 22\% das EFs há a expetativa de realizar uma mudança na gestão, especificamente a sucessão da liderança, entre os próximos 3 a 5 anos. Esta percentagem e período estão em linha com o ciclo normal de mudança geracional (25 anos);

- Das que admitem uma sucessão da propriedade, nos próximos 3 a 5 anos, a mudança passará pela transferência da propriedade entre familiares, sendo menos provável a abertura do capital social a membros não familiares ou a venda da empresa;

- Para a generalidade das empresas familiares, o sucessor da liderança da empresa deve ser procurado naturalmente no seio da família, sendo poucas as que admitem a entrada de gestores/líderes externos à família ou dentro do quadro de colaboradores/trabalhadores da empresa.

\section{Fatores de sucesso (e críticos) da empresa familiar}

Três fatores que mais contribuem, em termos relativos, para o sucesso de uma empresa familiar são:

- Separação dos interesses da família e os dos negócios;

- Existência de um planeamento estratégico a médio e longo prazo;

- Preparação e treino do sucessor antes do início efetivo de funções.
Para tal, importa desenvolver:

- Estrutura de governance que permita organizar procedimentos que estão na base do processo de tomada de decisão, incluindo a preparação da sucessão;

- Protocolo Familiar e vinculatividade dos acordos alcançados.

\section{Desafios e vulnerabilidades das EFs quando comparadas com os seus concorrentes}

Cinco pontos fortes mais valorizados:

- Valorização do atendimento ao cliente;

- Preços competitivos;

- Diversidade de produtos;

- Decisões rápidas e de forma flexível;

- Marca forte ou presença no mercado.

Pontos fortes menos valorizados:

- Ligação a centros de I\&D tecnológicos e de conhecimento;

- Marketing com impacto junto dos mercados;

Atração e fixação de trabalhadores com melhores competências;

- Robustez financeira ou facilidade de acesso ao capital. 
Principais preocupações das EFs face à concorrência, sinalizando sobretudo:

- Peso da carga tributária;

- Incerteza do ambiente económico e financeiro;

- Retração das vendas;

- Redução do lucro.

No polo oposto, entre os aspetos não identificados como principais preocupações, registam-se:

- Transferência da propriedade para um ou mais membros da próxima geração;

- Gestão de familiares na empresa;

- Gestão de conflitos e a profissionalização da gestão da empresa.

Estas últimas três referências consideradas como de menor preocupação assumem particular relevância dado que representam os principais fatores que levam ao desaparecimento das empresas familiares.

\section{Testemunhos e narrativas de empresário(a)s familiares}

Uma parte relevante do estudo suportou-se no testemunho direto de empresário(a)s.
Dos 23 entrevistado(a)s, dois terços são do sexo masculino, têm idades compreendidas entre os 30 e os 60 anos (mais expressivo o intervalo etário dos 40 aos 50 anos), e a esmagadora maioria detém o ensino superior (licenciatura, incluindo mestrado e doutoramento). São empresário(a)s fundadores(as)

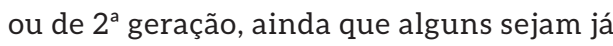
de $3^{\mathrm{a}}$ ou mais gerações, que assumem predominantemente estatuto de sócio gerente ou CEO e estão à frente dos destinos da empresa tendencialmente há mais de 20 anos. Quase todos são casados, com o registo de situações de divórcio ou assumindo o estatuto de solteiro. $O$ agregado familiar tende a ser constituído sobretudo por dois a três elementos, o que nos remete para a importância do cônjuge e de filhos na dinâmica da relação da família com a empresa.

Principais temáticas das narrativas obtidas estruturadas em torno de: Internacionalização e inovação; Diferenciação, inovação e economia digital; Autofinanciamento e controlo patrimonial; Visão e missão do(a) fundador(a): o "espírito empreendedor"; "Honrar a família": orgulho, lealdade, compromisso e confiança; Qualificar os membros familiares; (In)formalidade das decisões e planeamento; Manutenção do negócio nas "mãos" da família; Naturalização e adiamento da sucessão familiar; Conciliação (difícil) da vida familiar com a empresa; Descentralizar, desburocratizar e legislar. 



\section{INTRODUC̣ÃO}

O projeto "Roadmap para Empresas Familiares Portuguesas" (NORTE-02-0853-FEDER-000018) insere-se no Eixo Prioritário - Sistema de apoio às ações coletivas - "Qualificação", com o Objetivo Temático: "Reforçar a competitividade das pequenas e médias empresas".

Liderado pela Universidade do Minho, pelo Centro Interdisciplinar de Ciências Sociais Polo Universidade do Minho (CICS.UMinho), e em co-promoção com a Associação Empresarial de Portugal (AEP), este projeto visou mapear as empresas familiares na região Norte, conferindo visibilidade político-institucional desta tipologia empresarial. Com efeito, assinale-se a ausência de conhecimento sistematizado e atualizado sobre quantas são as empresas familiares e qual o seu contributo para a criação de riqueza, emprego e desenvolvimento local associado à cultura e ligação afetiva do(a) s fundador(a)s. Além disso, desconhecem-se as motivações que estão na base da constituição de novas empresas familiares associadas à inovação e transferência de tecnologia e conhecimento (e.g. start-ups), com potencial de transformação do padrão tradicional de especialização da economia portuguesa.

A singularidade das empresas familiares surge da coexistência, interação e sobreposição de três grupos independentes: a propriedade, a empresa e a família. As empresas familiares têm características que são comuns a outro tipo de empresas, mas, simultaneamente, diferem das demais devido à influência da família na mobilização de recursos, humanos e financeiros, e na configuração estratégica e cultural da empresa.
No quadro da crescente internacionalização da economia portuguesa e dos impactos da Revolução 4.0, em especial a economia digital e a desmaterialização dos processos produtivos, importa aprofundar o conhecimento sobre as especificidades das empresas familiares. São sobretudo desafios específicos que se orientam para tópicos como, por exemplo, a menor atenção dos decisores políticos sobre as especificidades das empresas familiares e sua contribuição económica e social; a menor atenção quanto às questões de planeamento da sucessão e/ ou estratégico; o desafio da profissionalização do negócio, mantendo o equilíbrio entre família, propriedade e empresa; as dificuldades em atraírem e reterem mão-de-obra qualificada (talento)/ profissionalização das carreiras.

Trata-se de um estudo pioneiro e inovador em Portugal, que conjuga a vertente de mapeamento das empresas familiares na região Norte com a sua caraterização e aprofundamento junto de uma amostra muito robusta focada nesta realidade empresarial. Ao se reconhecer a relevância das empresas familiares, não se identificou uma análise aprofundada das mesmas, o que reforça este trabalho e, em especial, a sua limitação geográfica às NUTS III do norte do país.

Este projeto concretiza o desígnio primeiro de construir uma base de dados de empresas familiares da região Norte, com o registo de 41.496 entidades empresariais. Além disso, disponibiliza, em simultâneo, uma radiografia das empresas familiares, por dimensão e antiguidade, acompanhada pelos testemunhos e narrativas de empresário(a)s que participaram nas diversas ações 
do projeto. Foi possível obter um conhecimento exaustivo e investigação consistente sobre os perfis das empresas familiares, assegurando a sua visibilidade e relevância, com particular destaque para os fatores de emprego, internacionalização e profissionalização transversais na economia. Por sua vez, a partilha e a discussão dos principais resultados concretizaram-se através da participação em diversos eventos de divulgação técnico-científicos (e.g. palestras e artigos) na academia e em contexto empresarial, local e associativo.

Para melhor disseminar os resultados obtidos, este livro estrutura-se em duas partes, visando restituir especificidade, heterogeneidade, complexidade e profundidade ao conhecimento sobre as empresas familiares.

Numa primeira parte, justifica-se a importância deste projeto, introduzindo a temática central e os seus objetivos estratégicos e operacionais. Descrevem-se, ainda, as quatro principais ações que corporizam o projeto, elencando as atividades em que se desdobraram e, sobretudo, os resultados obtidos em cada uma delas. $O$ roteiro metodológico é brevemente apresentado, com destaque para os enfoques múltiplos prosseguidos, designadamente quantitativo, qualitativo e participativo.

Na segunda parte, tem lugar a apresentação dos principais resultados obtidos no âmbito do projeto. Parte-se de uma visão macro e extensiva à região Norte, com a análise de um conjunto de indicadores de caraterização ao se privilegiar a dimensão e a antiguidade das empresas familiares. Integra-se a informação resultante da criação da BD Roadmapef da região Norte, do questionário aplicado a uma amostra de 1.148 empresas familiares e, por fim, de um conjunto de testemunhos selecionado a partir de temáticas cruciais ao debate e à reflexão dos desafios e singularidades das empresas familiares na atualidade.

Com esta publicação pretende-se efetivar a prática de devolução dos resultados obtidos, cumprindo requisitos não apenas de relevância político-social e de produção científica, como dar corpo aos princípios de uma praxis ético-deontológica assente na disseminação do conhecimento produzido, com envolvimento dos atores sociais enquanto (co)autores do mesmo. 


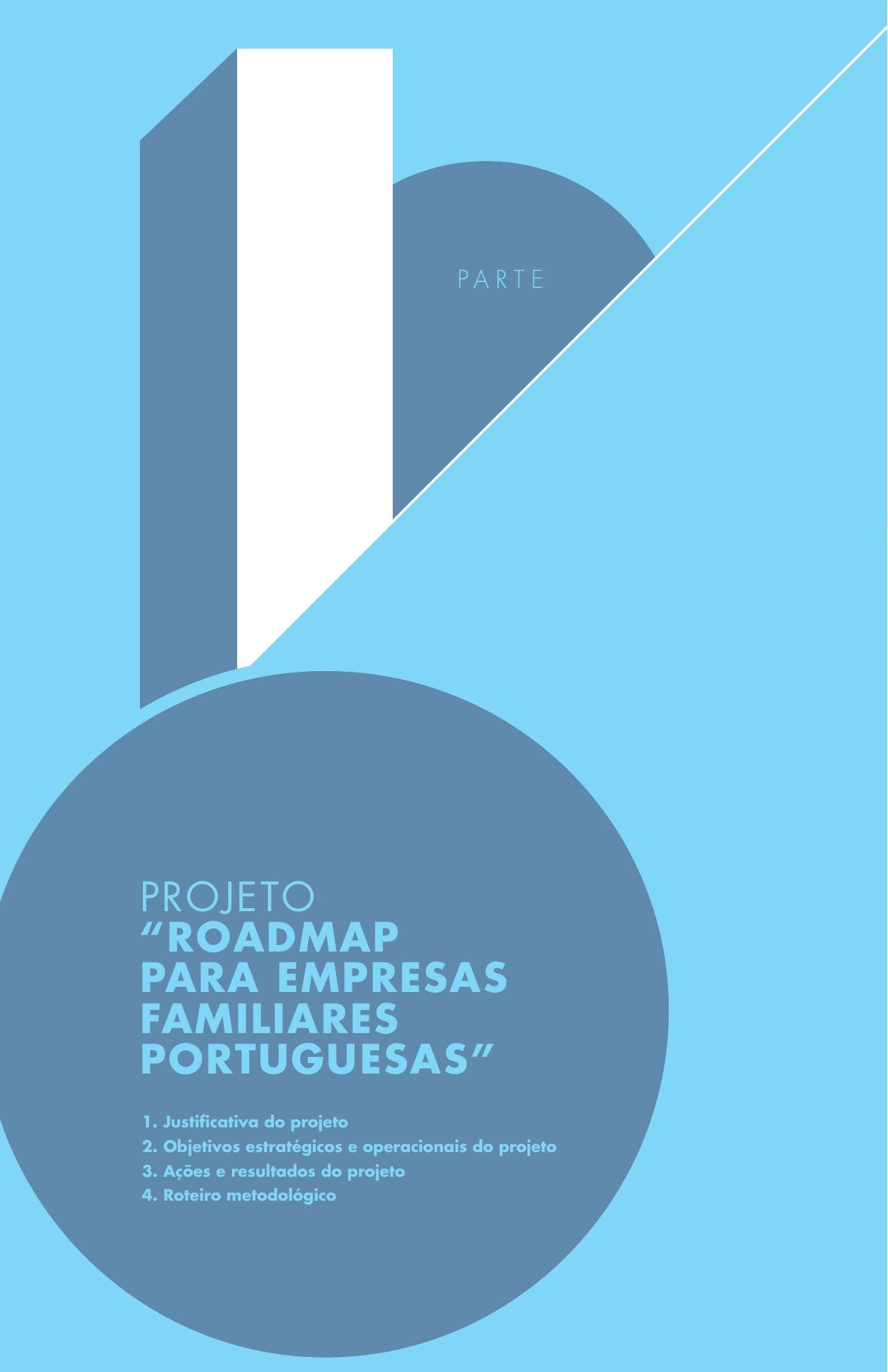




\section{Nesta parte, justifica-se a pertinência do presente estudo centrado nas empresas familiares na região Norte, apresentando-se, em paralelo, os seus objetivos estratégicos e operacionais no quadro do projeto "Roadmap para Empresas Familiares Portuguesas". Segue-se a descrição das ações e resulfados obtidos, acompanhada pela exposição breve do roteiro metodológico que estruturou o desenho de pesquisa.}

\section{Justificativa do projeto}

Com uma visão de longo prazo, as Empresas Familiares (EFs) contribuem significativamente para o PIB e o emprego, para a inovação e desenvolvimento das comunidades locais, constituindo um dos pilares do crescimento da economia de qualquer país. Em contexto nacional, este projeto responde a uma ausência de conhecimento exaustivo e investigação consistente sobre o perfil das empresas familiares, assegurando a sua visibilidade e relevância, com particular destaque para os fatores do emprego, internacionalização e profissionalização transversais na economia.

Do ponto de vista político-económico e socio-organizacional são vários os argumentos que sustentam a pertinência da uma discussão sobre a temática do lugar e papel da empresa familiar.

Em primeiro lugar, as empresas familiares constituem a forma empresarial dominante, sendo o seu sucesso e a longa estabilidade fundamentais para a economia e sociedade. Porém, um dos maiores problemas que as empresas familiares enfrentam na Europa e em Portugal é a falta de visibilidade político-institucional, onde não existem ainda estatísticas oficiais precisas e atualizadas sobre este setor da economia. Existem apenas estimativas que exprimem a importância desta tipologia empresarial no cômputo geral das empresas na economia privada, variando de país para país.

Segundo o relatório da Comissão da Indústria, da Investigação e da Energia, sob a alçada da União Europeia, 85\% de todas as empresas europeias são empresas familiares e estas representam 60\% dos empregos no setor privado ${ }^{1}$. Para Espanha, as empresas familiares representam sensivelmente 75\% do total das empresas; já em Portugal, prevê-se que as empresas familiares possam representar entre $70 \%$ a $80 \%$ das empresas nacionais, absorvendo $50 \%$ da força de trabalho e contribuindo para $2 / 3$ do $\mathrm{PIB}^{2}$. Alargando ao

\footnotetext{
1 Informação em linha: http://www.europarl.europa.eu/oeil/popups/printsummary.pdf?id=1395260\&l=en\&t=D - Acesso a 4.4.18].

2 Informação em linha: http://www.empresasfamiliares.pt/quem-somos - Acesso a 4.4.2018].
} 
espaço não europeu ${ }^{3}$, é possível estimar importâncias relativas mais significativas das empresas familiares em países como Austrália (70\%), América Latina (entre 65\% a 90\%) e Estados Unidos da América (entre 90 a 95\%) (International Family Enterprise Research Academy [IFERA], 2003).

Urge, por isso, disponibilizar informação estatística fiável e atual sobre as empresas familiares, cuja lacuna se encontra sinalizada para o contexto nacional e europeu, tal como documentação de referência o atesta ao reforçar o papel das pequenas e médias empresas familiares como parte substancial das companhias Europeias Small Business Act (COM, 2008) e do dinamismo da economia europeia (EC, 2009).

Em segundo lugar, é importante destacar a heterogeneidade interna e os desafios específicos que caraterizam esta tipologia de empresas. Integrando maioritariamente Pequenas e Médias Empresas (PME), as empresas familiares encontram-se distribuídas por setores de atividades diversos como, por exemplo, comércio por grosso e a retalho, alojamento e restauração, construção, educação, saúde humana e apoio social, pescas, entre outros. Com efeito, não se consegue ainda precisar quanto das PME, incluindo microempresas (até 9 trabalhadores), para além de grandes empresas, podem ser ou não empresas familiares e, caso o sejam, desconhecem-se as suas dinâmicas no contributo (potencial) para os mercados nacional e internacional.

Na verdade, sob a mesma designação de "empresa familiar" existem realidades distintas consoante a dimensão, o grau de profissionalização de gestão e governo, as estruturas organizacionais e de mão-de-obra. Assumem, por vezes, complexas redes de subcontratação ou outsourcing, que permitem dinamizar nichos de mercado emergentes de valor acrescentado, ou externalizar atividades da cadeia produtiva. Neste contexto, podem incluir empresas familiares que sobrevivem para sustentar o "negócio" da família ou, em sentido oposto, assumirem-se como agentes económicos de grande relevo e cotadas na bolsa, constituindo grupos económicos de grande expressão. Podem incluir empresas com níveis de inovação e profissionalização significativos, sendo, porém, mais evidentes os défices no que diz respeito à economia digital $\mathrm{e}$ inovação no quadro da Indústria 4.0 e de profissionalização do negócio (governance), gestores e recursos humanos.

A menor atenção e/ou preparação das empresas familiares para o planeamento da sucessão, assume uma dimensão crítica na sustentabilidade do negócio familiar. Segundo um estudo recente orientado para a importância da sucessão empresarial em Portugal (AEP, 2011), 50\% das empresas familiares não passam para a segunda geração e somente $20 \%$ alcançam a terceira geração. Assim, assume relevância o planeamento da sucessão empresarial, sendo visíveis vários os desafios que se desenvolvem a partir das questões internas às próprias empresas familiares. Sem pretendermos ser exaustivos, sinalizam-se os seguintes: i) a menor atenção/ preparação das empresas familiares para o planeamento da sucessão da propriedade/ liderança empresarial; ii) exigências de equilíbrio entre família, propriedade e aspetos do negócio; iii) vulnerabilidade na retenção de mão-de-obra, sobretudo, qualificada,

\footnotetext{
3 Empresas familiares são a forma mais omnipresente de organização empresarial na Europa. Todavia, só recentemente se tem vindo a desenvolver estudos sobre esta temática já que, até então, a maior parte da literatura existente foi desenvolvida dentro de um contexto norte-americano (Botero, De Massias \& Nordqvist, 2015).
} 
em parte por se associar às empresas familiares uma "má imagem" quanto à prevalência de carreiras e/ou práticas de nepotismo ou paternalismo.

Perante aquelas estimativas e a heterogeneidade interna de que reveste a empresa familiar, a questão que se coloca é: o que é uma empresa familiar? Ou, dito de outro modo, o que permite distinguir uma empresa familiar de uma não familiar? A resposta a esta questão exige um debate sobre a urgência de se estabilizar a definição de empresa familiar. Não há uma definição consensualizada entre as entidades governamentais, os agentes económicos e os diversos cientistas dedicados a esta temática, apesar do recente esforço do Grupo de Peritos criado pela Comissão Europeia (EC, 2009). Todavia, assume-se no presente estudo a definição de empresa familiar como aquela em que a família detém a propriedade e/ou controlo em termos de nomear a gestão da mesma, e em que alguns dos seus membros participam e trabalham na empresa. Mais à frente, teremos oportunidade de retomar esta discussão.

Em terceiro lugar, estas empresas familiares assumem uma certa invisibilidade/ depreciação do seu potencial na transformação do padrão de especialização industrial, de inovação e transferência de tecnologia e conhecimento. São ainda desconhecidos os efeitos das empresas familiares quanto:

i) ao seu contributo económico na cadeia de criação de riqueza e valor acrescentado, em especial quanto à absorção de transferência de tecnologia e conhecimento (sobretudo por via de start-ups e iniciativas empreendedoras ligadas à setores de I\&D e inovação) e também por via da adesão à economia digital; ii) ao volume de emprego criado e consolidado ao longo do ciclo da atividade económica, absorvendo em especial mão-de-obra qualificada;

iii) à capacidade de inovação ao nível dos processos, materiais e bens/ serviços que, produzidos localmente, têm vindo a conquistar mercados internacionais e globalizados;

iv) aos modelos de profissionalização e liderança, considerando as suas especificidades, incluindo aqui os fatores mais críticos de gestão de conflitos família - empresa - inteligência emocional;

v) à capacidade de organização em redes e parcerias, partilhando os recursos disponíveis por via da utilização de plataformas online colaborativas de agentes sociais e económicos diversos (desde centros de I\&D, universidades, escolas profissionais a clientes e fornecedores);

vi) ao potencial de desenvolvimento da coesão territorial pela capacidade de atração e fixação de recursos humanos localmente, realçando o papel deste tipo de empresas em termos de estabilidade que apresentam a longo prazo e da ligação especial que desenvolvem com as comunidades locais.

Há que elencar, igualmente, um conjunto de argumentos que enfatiza a dimensão intangível das empresas familiares, designadamente de cariz social e simbólico-valorativo, conferindo um retrato completo da importância desta tipologia empresarial na economia e sociedade em geral.

Sabe-se que as estruturas familiares se transformaram ao longo dos séculos e, muito em especial, no séc. XX em se assiste a alterações da família 
tradicional patriarcal e, subsequentemente, ao aparecimento da família conjugal moderna. Esta expressa a transformação mais vasta da conjuntura sociocultural num determinado espaço e tempo histórico. A família conjugal moderna assume o modelo da família burguesa, cristã católica que se solidifica e predomina até meados dos anos 70. Neste contexto, fala-se de uma família estritamente associada ao casamento, de acordo com orientações sociais e religiosas. Ou seja, de uma família hierarquizada, com papéis sociais e de género bem definidos (Torres, 2002; Leandro, 2001). Já o séc. XXI mostra um declínio do casamento, um aumento dos divórcios, uma subida da coabitação, múltiplos arranjos conjugais e novos laços de parentesco (Rosa \& Chitas, 2010; Wall, 2005).

As principais tendências de evolução da vida em família são reveladoras de outras recomposições familiares, que passam pela maior presença de uniões de facto e experiências de vida conjunta sem formalização da relação, do decréscimo da natalidade, juntamente com o aumento da idade média das pessoas se casarem e terem filhos, do maior investimento na formação académica dos descendentes e desenvolvimento profissional.

As transformações na estrutura familiar na contemporaneidade implicam uma redefinição do conceito de família e a discussão da sua influência na empresa é crucial, justamente pelo peso que a família assume na dimensão da socialização e transmissão de valores e normas orientadas para o negócio. A mobilização do capital social e simbólico enquanto recurso interno à família, interpenetra na dinâmica empresarial da mesma. Nesse sentido, importa conferir visibilidade à cultura, às relações de poder (e.g. conciliação, conflito), mas também às relações de cumplicidade, respeito, confiança dos membros familiares (executivos e não executivos) envolvidos na vida das empresas familiares e conciliação com a família.

Estas práticas subjetivizadas aproximam-se do habitus dos indivíduos (Bourdieu, 1979), entendido como sistemas específicos de disposições e predisposições para a ação, que incluem tanto as representações sobre si e sobre a realidade, como também sistemas de práticas em que a pessoa inclui valores e crenças, aspirações e projeções. Por tal, estes ssitemas autorreguladores de princípios implícitos e explícitos da ação, em regra com forte pendor emocional, assumem uma dimensão crucial tanto na vida intrafamiliar e empresarial como nas relações entre família, empresa e sociedade em geral. Tendem a configurar estratégias de preservação do património material (posição assumida na estrutura social de classes) e imaterial, relacionadas com os recursos económicos (e de propriedade) e o investimento em credenciais escolares. Incluem, também, estratégias de transmissão do ethos familiar, suas tradições e valores, para além da manutenção do "segredo" do negócio na família e ligação privilegiada à comunidade envolvente.

Assim, quando se fala de empresas familiares, importa dar destaque ao fundador(a) e/ou proprietário(a), em especial quanto à responsabilidade e aos valores que defende, para além da questão da atividade empresarial em si. A confiança, o respeito, o conhecimento de cada um dos clientes, assim como o "rosto" da empresa permitem acrescentar valor de mercado à empresa familiar, num contexto de volatilidade de contactos e efemeridade de satisfação das necessidades na atualidade.

Desta forma, na trajetória de uma empresa familiar, e em articulação com as suas gerações, são importantes os fatores de conhecimento, reputação, "espírito" empreendedor, confiança e 
comunicação entre os membros da família, mas também o processo de socialização, profissionalização e flexibilização na gestão de (novos) membros das famílias empresárias com o compromisso e a transparência nas relações que se estabelecem entre empresa e família. Estes aspetos permitem aferir a "cultura familiar" no sentido de familiness (Habbershon \& Williams, 1999), através dos recursos que a empresa familiar dispõe na interação com a família como um todo.

A importância da reputação familiar e a preocupação em manter a liderança familiar permitem, por sua vez, evidenciar uma maior predisposição das empresas familiares para a responsabilidade social, traduzida num sentido de obrigação da família em servir a sociedade. Dir-se-á que as empresas familiares são em si uma "marca" intangível, à qual importa acrescentar os meios ou os recursos tangíveis com os quais a atividade económica se desenvolve. Nesse sentido, as empresas familiares caraterizam-se pela sua resiliência e manutenção de um vínculo emocional com o lugar onde nascem, o sítio onde originariamente começaram a sua atividade. A sua estabilidade, compromisso e coesão territorial fazem destes agentes económicos atores relevantes para o desenvolvimento local não só diretamente com a criação de emprego, mas também através de iniciativas de promoção regional. Na verdade, devido à sua história, as empresas familiares estão fortemente enraizadas em um determinado local e, portanto, também criam e mantêm zonas rurais e desfavorecidas, contribuindo para a luta contra o processo de envelhecimento e despovoamento, das regiões em que as mesmas se encontram inseridas.

Da exposição do conjunto de argumentos sobre a relevância nacional e internacional das empresas familiares, apresenta-se de seguida uma análise sistematizada a partir de uma matriz SWOT (Figura 1). Esta destaca os aspetos relevantes ao nível dos pontos fortes e fracos, oportunidades e ameaças das empresas familiares na atualidade, e permite enquadrar e fundamentar as ações que estruturam o projeto que dá corpo ao presente relatório. 


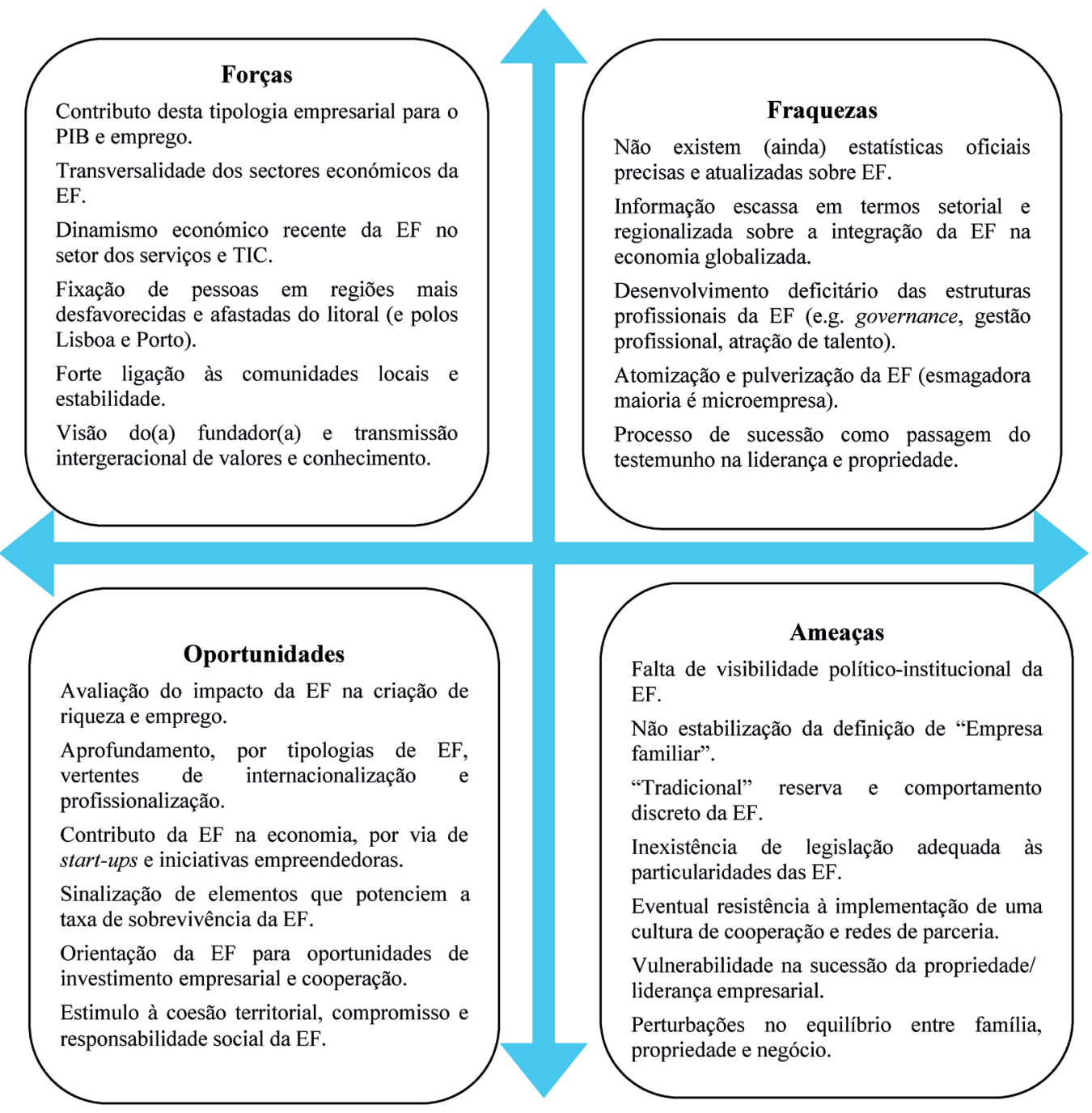




\section{Objetivos estratégicos e operacionais do projeto}

Com uma duração de dois anos (2016-2018), o projeto "Roadmap para Empresas Familiares Portuguesas", financiado pelo NORTE2020 e FEDER, prosseguiu um duplo objetivo estratégico:

(1) mapear as empresas familiares da Região Norte, que podem ser pequenas, médias ou grandes;
(2) e avaliar o seu impacto na economia local, nacional e internacional, tendo, por um lado, em conta a dinâmica de criação de emprego, internacionalização e inovação do investimento, e, por outro, a profissionalização de gestão e governo das empresas familiares.

FIGURA 2. Porquê mapear as EFs da região Norte?

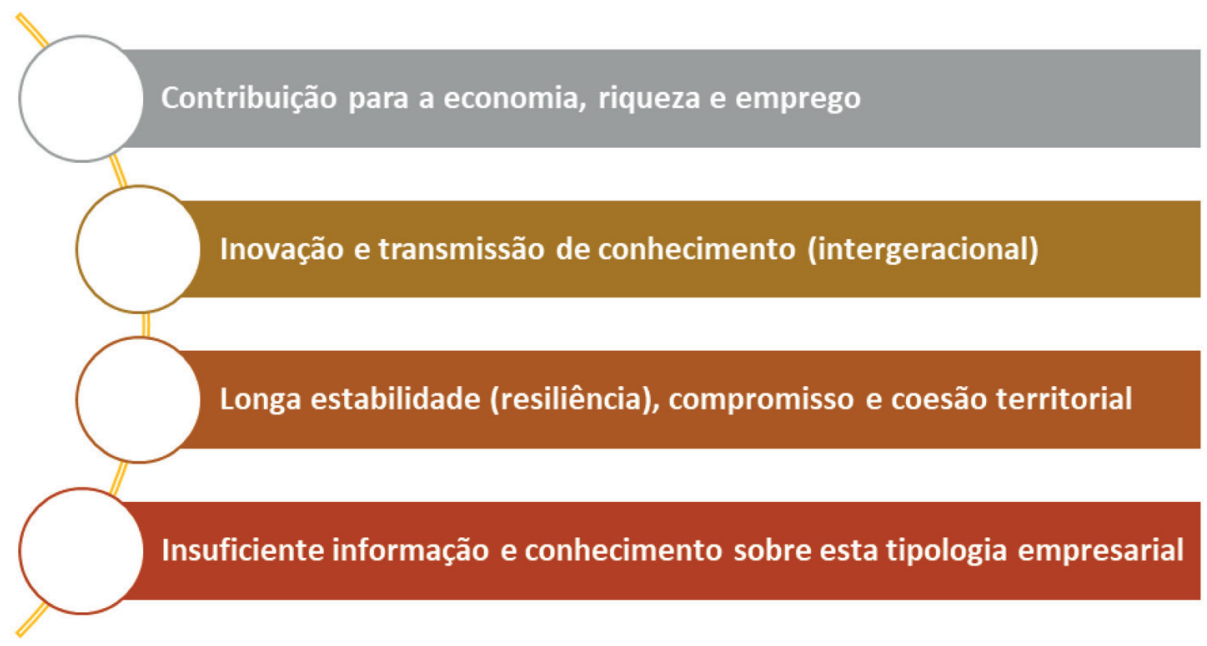


Para obtenção de um conhecimento exaustivo e de uma investigação consistente sobre o perfil das empresas familiares da região Norte, foram definidos 4 objetivos operacionais:

1. Mapear as empresas familiares da região Norte, através da construção de uma base de dados dos tipos e segmentos de famílias empresariais portuguesas (e.g. variáveis sociodemográficas, volume de negócios, dimensão, setor de atividade). A materialização de bases de dados com informação relevante permitirá informar e apoiar adequadamente a tomada de decisão nos domínios da economia, da educação e da política (no sentido mais amplo).

2. Conceber um questionário a aplicar a uma amostra de empresas familiares do nosso universo-alvo constituído pela base de dados, com incidência em dimensões relevantes, nomeadamente no domínio da internacionalização, governo das empresas familiares, profissionalização da gestão, sucessão, fatores críticos e fortes das empresas familiares face à concorrência.
3. Autonomizar a informação sobre empresas familiares num site próprio (www.roadmapef. ics.uminho.pt), de acesso fácil e com conteúdos diversificados, permitindo, igualmente, divulgar e disseminar informação e ações em curso do projeto, contribuindo para aumentar a visibilidade das empresas familiares.

4. Propor iniciativas em parceria com empresários, associações empresariais, entidades académicas e governativas (poder local e central), entre outras, de modo a dar visibilidade às sociedades familiares através de iniciativas que permitam captar a atenção do meios académico, associativo e político e gerar e disseminar informação.

\section{Ações e resultados do projeto}

A partir dos objetivos estratégicos e operacionais foram desenhadas quatro ações do projeto (Figura 3). Estas, em articulação com um conjunto de atividades implementadas no terreno, são responsáveis pelos resultados principais do projeto "Roadmap para Empresas Familiares Portuguesas".

FIGURA 3. Ações do projeto

\begin{tabular}{|l|l|}
\hline - Criação da base de dados de EFs da região Norte \\
\hline Ação & Açação do questionário online e presencial às EFs da região Norte \\
4
\end{tabular}




\section{AÇÃO 1 \\ CRIAÇÃO DA BASE DE DADOS DE EFS DA REGIÃO NORTE}

\section{RESULTADO \\ - BASE DADOS ROADMAPEF ( $N=41.496$ EMPRESAS FAMILIARES \\ DA REGIÃO NORTE)}

O diagnóstico sobre a economia portuguesa aponta para um conhecimento ainda incipiente sobre as empresas familiares, as dinâmicas de inovação e profissionalização deste setor no território nacional, bem como sobre o seu contributo para a internacionalização da economia.

O consórcio entre o Centro Interdisciplinar de Ciências Sociais, Polo Universidade do Minho (CICS.UMinho) e a Associação Empresarial de Portugal (AEP), congregou esforços no sentido de mobilizar especialistas e entidades credenciadas neste domínio para a construção de uma base de dados de empresas familiares na região Norte.

Nesta Ação 1 foram desenvolvidas as seguintes as atividades:

1. Pesquisa documental de suporte ao conceito de "empresa familiar" usado neste estudo;

2. Acesso a fontes de informação para a sinalização de "empresa familiar";

3. Estabilização dos campos de informação relevantes constitutivos da base de dados de empresas familiares.

Como resultado desta Ação 1 foi criada a Base dados Roadmapef. Constitui a primeiro registo sobre quantas empresas familiares existem na região Norte, colmatando a lacuna sinalizada para o contexto nacional e europeu, tal como documentação de referência o atesta. Além disso, esta base de dados, ao estar disponível num site específico das empresas familiares, permite uma atualização contínua dos registos das empresas. Trata-se, portanto, de uma ferramenta perene que poderá assegurar uma maior dinâmica de estudo sobre esta tipologia de empresas familiares e um maior reconhecimento por parte da sociedade do impacto destas empresas no mercado e na comunidade.

Sempre que disponível, esta base de dados integrará dois tipos de informação: a) informação fixa relacionada com a identificação da empresa; b) informação variável, passível de atualização periódica.

\section{AÇÃO 2}

\section{QUESTIONÁRIO EFS DA REGIÃO NORTE}

\section{RESULTADOS \\ - AMOSTRA DE EFS DA REGIÃO NORTE ( $N=1.148)$ \\ - REALIZAÇÃO DE 23 ENTREVISTAS A EMPRESÁRIO(A)S}

A construção e a aplicação do questionário online e presencial consistiu no objetivo central da Ação 2, que se suportou em quatro atividades principais:

1. Pesquisa de modelos de questionários de referência nacional e internacional;

2. Ensaios de planos de amostragem a partir das caraterísticas do universo alvo - Base dados Roadmapef;

3. Entrevistas a empresário(a)s familiares;

4. Utilização da plataforma do LimeSurvey para criação do questionário online (Open-Source Suryeys) 
Através do questionário obteve-se uma primeira radiografia das empresas familiares, indispensável ao conhecimento e à avaliação do papel do seu papel e contributo para a economia local, nacional e internacional. Complementarmente, realizaram-se entrevistas aprofundadas como suporte à conceção do questionário aplicado às empresas familiares.

Por sua vez, a plataforma do LimeSurvey constitui um software para criação de questionário online (Open-Source Suryeys), de fácil acesso e operacionalização por via da geração de tokens (mensagens automáticas) de apelo ao preenchimento do mesmo. O sistema oferece análise estatística com base nos resultados do questionário, sendo que as pesquisas podem ser acessíveis ao público ou de acesso controlado, através do uso de chaves para cada participante do questionário. Não obstante a importância daquela ferramenta online foi necessário incluir uma fase presencial de aplicação dos questionários às empresas familiares.

Este questionário encontra-se alojado no site oficial do projeto "Roadmap para Empresas Familiares Portuguesas", podendo ser preenchido em qualquer momento e alargado para um universo mais amplo, com possibilidades de comparação com outras regiões e outras tipologias de empresa, em futuras candidaturas/ projetos de investigação que venham a se associar. Constitui um instrumento essencial para outros estudos futuros nesta área e para um conhecimento aprofundado das dinâmicas socioeconómicas destas empresas a nível regional, em especial com o envolvimento de estudantes de (pós)graduação e investigadores interessados nesta temática.

\section{AÇÃO 3}

\section{SITE OFICIAL DO PROJETO E DISSEMINAC̣ÃO DOS RESULTADOS}

\author{
RESULTADOS \\ - LOGOTIPO IDENTITÁRIO DO PROJETO \\ - SITE DO PROJETO: WWW.ROADMAPEF.ICS.UMINHO.PT
}

No servidor disponível no Instituto de Ciências Sociais (ICS) da Universidade do Minho - plataforma LASICS - encontra-se alojada a página oficial do projeto: $w w w$.roadmapef.ics.uminho. pt (Figura 4). Este site, ao qual foi associado um logotipo de identificação do projeto, permite fornecer várias funcionalidades ou "serviços", nomeadamente a partilha de recursos do sistema.

Seguro e fiável, funciona como espaço de apresentação de informação do projeto em si, desde os objetivos, ações, parceiros, iniciativas realizadas (sessões de divulgação, workshops, seminários, publicações e outros eventos) e de divulgação, comunicação e disseminação dos resultados obtidos. Enquanto plataforma de disseminação de informação e resultados do projeto, permite igualmente que o mesmo seja alvo de consulta por parte de outras instituições e públicos diversificados.

As atividades que suportam a Ação 3 são diversas, sendo de referir as seguintes:

1. Conceção de um logo de identificação do projeto;

2. Atualização e manutenção do site;

3. Gestão de conteúdos do site;

4. Disseminação e devolução de informação sobre empresas familiares. 
FIGURA 4. Homepage do site www.roadmapefics.uminho.pt

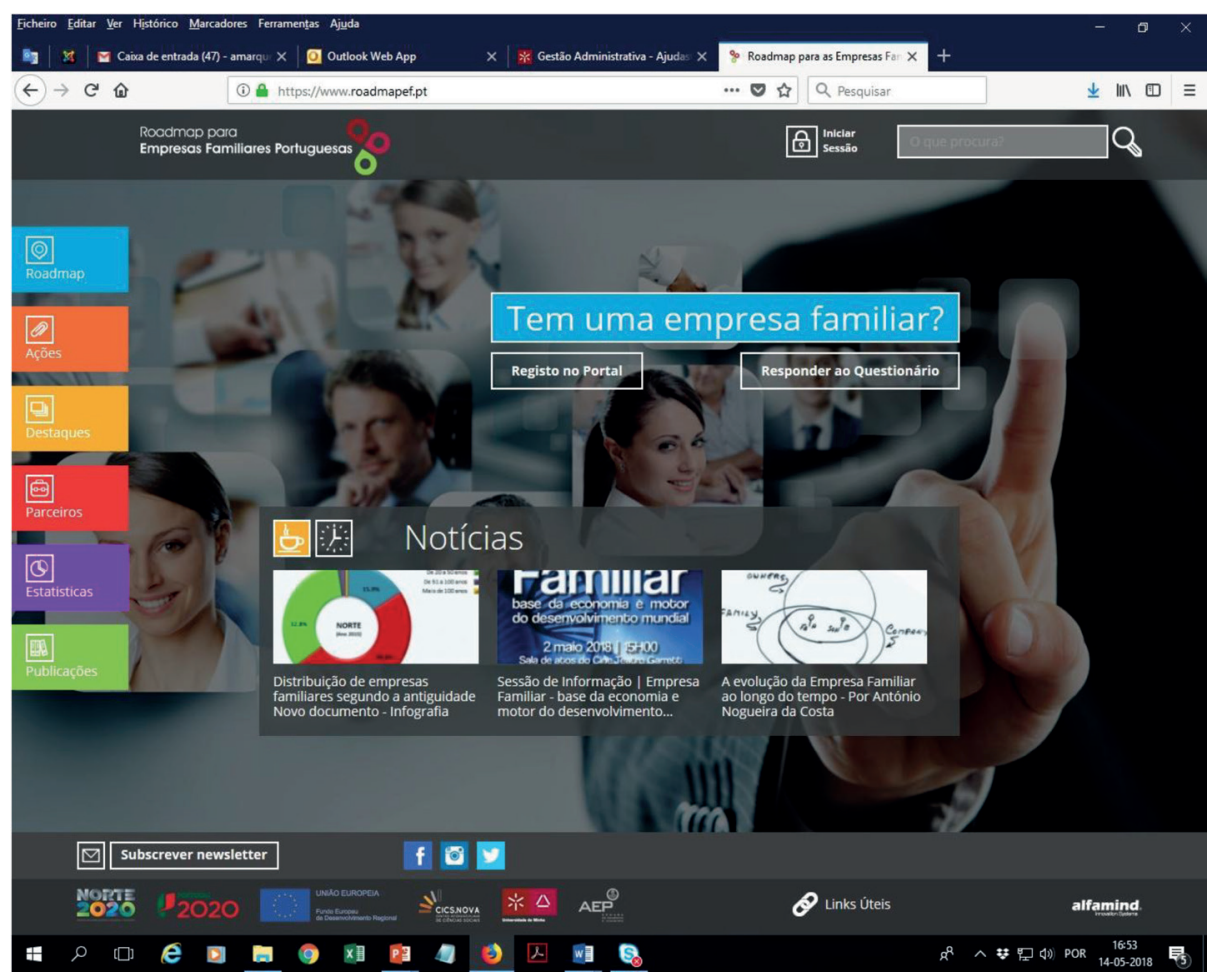

Com a construção deste este site é possível, simultaneamente: i) integrar as bases de dados disponíveis com o registo de novas empresas familiares e outros interlocutores, desde associações a investigadores nacionais e internacionais, cuja informação poderá ser atualizada periodicamente; ii) constituir-se no meio privilegiado para as empresas familiares responderem ao questionário previsto na Ação 1. Permite uma atualização constante dos dados sobre empresas familiares (monitorização e ações de melhoria em progresso), podendo ser consultados tanto por outras instituições, como investigadores e público em geral. Contribui, assim, para se aprofundar o conhecimento sobre as "especificidades" das empresas familiares e promover uma maior visibilidade (político-institucional) desta realidade económico-social da qual não existem suficientes dados oficiais detalhados, atuais e fiáveis.

A abertura às comunidades empresarial, associativa e científica, i.e., a um número mais vasto de utilizadores, constitui uma oportunidade relevante que importa destacar deste projeto, capacitando eventuais estudos neste domínio. 
Tal poderá, igualmente, potenciar o envolvimento de entidades governamentais nacionais na criação de políticas de apoio, incentivo e dinamização de empresas familiares e de soluções para superar os principais entraves que as mesmas encontram no mercado.

\section{AÇÃO 4}

\section{ORGANIZAC̣ÃO DE EVENTOS CIENTÍFICOS}

\section{E FORMATIVOS}

\section{RESULTADOS}

- 2 SESSÕES PÚBLICAS DE APRESENTAÇÃO DO PROJETO

- 2 SEMINÁRIOS INTERNACIONAIS

- CICLO DE WORKSHOPS POR NUTS III

A apresentação pública do projeto, a par da organização de dois seminários internacionais e de um ciclo de 8 workshops distribuídos por cada NUTS III que integra a região Norte, assumem um papel preponderante desta Ação 4. Esta tem como finalidade divulgar o trabalho feito e constitui uma estratégia relevante no envolvimento e dinamização das empresas familiares, contando com o apoio delas nas várias ações em que o projeto se estruturou.

No primeiro seminário internacional (12 de abril 2017), realizado nas instalações da AEP, e subordinado à temática "Empresas Familiares - Novos Desígnios - O Norte em Perspetiva", apresentou-se o projeto e principais estudos sobre as empresas familiares em contexto nacional e internacional.

No seminário internacional de encerramento do projeto (19 de setembro 2018) sobre "Empresas Familiares: Mapeamento, profissionalização e inovação", na Plataforma das Artes e Criatividade (PAC) em Guimarães, foram apresentados e comentados os resultados globais do projeto, com a participação de mais de duas dezenas de especialistas e/ ou académicos.

A Ação 4 estruturou-se nas seguintes atividades:

1. Organização de duas sessões públicas de apresentação do projeto: ICS da Universidade do Minho e AEP;

2. Realização de dois seminários internacionais: AEP e UM - Plataforma das Artes e Criatividade (PAC) em Guimarães;

3. Ciclo de 8 workshops distribuídos por NUTS III da região Norte;

4. Plano comunicacional assente na gestão dos conteúdos e na disseminação no site, meios de comunicação e redes sociais;

5. Participação em ações e eventos para a divulgação do projeto e seus primeiros resultados.

Quanto ao ciclo de workshops subordinado à temática "Empresas familiares: Enfrentar os desafios, assegurar a continuidade", este permitiu que se apresentasse o projeto em cada uma das sub-regiões administrativas do Norte, os seus objetivos e ações, assim como dinamizar sessões formativas orientadas para questões "específicas" das empresas familiares. Simultaneamente, pretendia-se com estas sessões uma maior sensibilidade junto de empresário(a)s para o preenchimento do questionário online disponível no portal do site do projeto.

As câmaras e associações que se disponibilizaram a ser nossas parceiras nos workshops foram as seguintes: 
* Crédito Agrícola de Vila Verde e Terras do Bouro;

* Confraria dos Vinhos do Douro;

* Caixa do Crédito Agrícola - Caixa do Noroeste;

* NERBA - Associação Empresarial do Distrito de Bragança;

* Casa do Território - Equipamento cultural de Vila Nova de Famalicão;

Associação Empresarial de Amarante;

Oliva Creative Factory;

Associação Empresarial Botiquense.

Com o plano comunicacional implementado pretendeu-se: i) divulgar todas as atividades realizadas no âmbito do projeto; ii) envolver, de forma direta, as empresas familiares na recolha da informação para a criação da base de dados; iii) disponibilizar informação atual e sistematizada sobre empresas familiares; iv) potenciar uma maior visibilidade do contributo das empresas familiares para a economia, os seus desafios e respetivo impacto na competitividade das regiões em que se localizam.

O logotipo concebido permitiu reforçar a estratégia de marketing digital, conferindo visibilidade das entidades promotoras do projeto e das empresas familiares, apelando ao seu registo no portal do site. Nesse sentido, visou-se alargar a divulgação a um público amplo, nomeadamente a públicos interessados, decisores políticos, investigadores com trabalho nesta área temática (e.g. internacionalização, inovação, economia digital, sucessão e liderança, crescimento e desempenho).

Envolveu-se igualmente conferencistas nacionais e internacionais considerados especialistas nesta temática, com vista a partilhar conhecimento e reforçar redes de internacionalização da informação, mostrando exemplos de boas práticas e a capacidade empreendedora desta tipologia empresarial.

Por último, foi possível participar em ações e eventos que permitiram a divulgação do projeto e primeiros resultados, designadamente: "O Desafio da Indústria 4.0 na Expansão e Internacionalização das Empresas Familiares", IV Encontro Fora da Caixa - A Indústria 4.0 na Dinâmica das Empresas Familiares, Organização Caixa Geral de Depósitos (Auditório VITA, Braga, 27 junho de 2017) e "Base da economia e motor do desenvolvimento mundial", organizado pela Associação de Empresas Familiares e Câmara da Póvoa de Varzim (Cine Teatro Garrett, Póvoa de Varzim, 2 de maio, 2018). Além disso, foram realizadas várias comunicações e publicados artigos em encontros e seminários académicos, nacionais e internacionais.

\section{Roteiro metodológico}

O presente estudo centrado sobre o mapeamento das empresas familiares na região Norte integra etapas metodológicas com diversos enfoques, designadamente quantitativo, qualitativo e participativo e respetivas técnicas de recolha e tratamento de informação. Durante os dois anos em que o mesmo se desenvolveu foi possível interagir com um leque alargado de públicos, desde empresas familiares, associações empresariais, entidades bancárias, câmara locais, a investigadores, estudantes de (pós)graduação e consultores/ especialista neste domínio temático.

O desenho metodológico suporta-se nos procedimentos a seguir expostos que se articulam com as ações previstas no projeto atrás descritas (Figura 5). 
FIGURA 5. Desenho metodológico

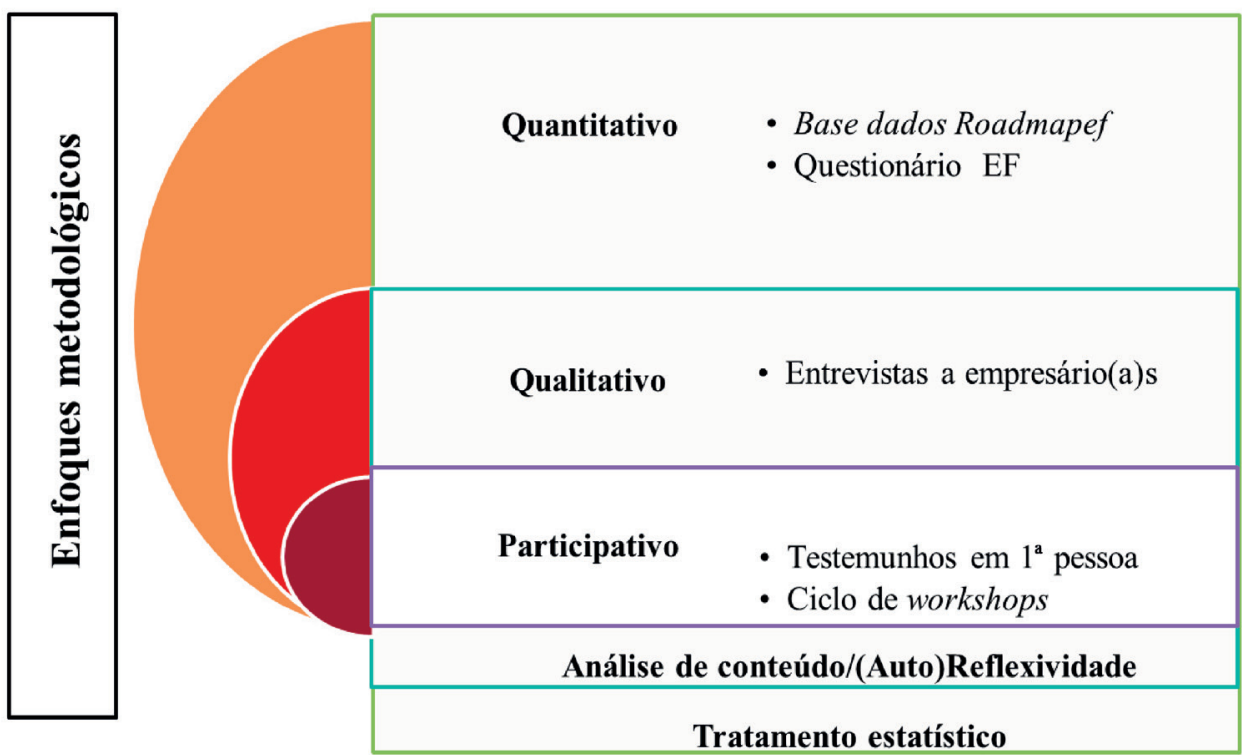

\section{1. Enfoque quantitativo}

\section{- Mapeamento e retratos das EFs}

\subsubsection{Estabilização do conceito}

"Empresa Familiar"

Para efeitos de trabalho no terreno, importava avançar com a estabilização do conceito de empresa familiar a utilizar no presente estudo. Assim, para a construção do indicador "Empresa Familiar" (EF), a opção recaiu na proposta de definição de empresas familiares avançada pelo Grupo de Peritos criado pela Comissão Europeia (2009) 4 . Para tal, assumem quatro elementos, ou dimensões, a serem contempladas na identificação das empresas familiares, distinguindo-se das empresas não familiares. Esses elementos são:
1. a maior parte das decisões é tomada pelo fundador da empresa, ou por aquele que recebeu o legado da empresa enquanto herdeiro natural, ou familiar indireto;

2. a maioria da tomada de decisões pode ser indireta ou direta;

3. pelo menos um ou mais familiares estão envolvidos no controlo da empresa;

4. e, finalmente, as empresas registadas são consideradas familiares quando a pessoa que a criou ou os seus familiares e descendentes possuem $25 \%$ de ações (capital da mesma).

4 A literatura especializada sobre o tema elenca mais de 90 definições e expõe a dificuldade da sua operacionalidade e consequente comparabilidade em termos não só nacionais, mas também internacionalmente. 
Com o objetivo de apresentar uma definição clara e operacional aos vários países da UE, esta definição assume-se como "não restritiva" e destaca a "influência" da família na vida empresarial como fator distintivo da empresa familiar de uma não familiar. Mais, reconhecem-se convergências estabilizadas na literatura da especialidade sobre a definição das empresas familiares a partir da sinalização de três elementos-chave: família, empresa e propriedade.

Para Tagiuri \& Davis (1992, 1982), há dois aspetos que nos ajudam nesta clarificação. Um deles reside na utilização de um modelo identificado por três círculos, em que se percebe que a família é o elemento central para a distinção entre empresas familiares e não familiares. Em segundo lugar, assume-se que o foco privilegiado de identificação das empresas familiares estará mais na qualidade das relações entre família e empresa, nomeadamente nas exigências de equilíbrio entre estas duas dimensões, do que nas questões do "lucro" ou das "perdas" em termos puramente economicistas. Assim, para os autores, uma empresa familiar define-se pela integração de três componentes: a empresa, propriamente dita - entidade que desenvolve o negócio; a propriedade - pessoas que possuem o seu capital; e a família - agrupamento de pessoas unidas por laços familiares e que, de alguma forma, se encontram associadas à empresa ou à propriedade. No desenvolvimento desta teoria, estabelecem-se três fases da vida da empresa e família: nascimento, crescimento da empresa e da família e implosão com a evolução dos negócios e da $3^{a}$ geração.

Com esta proposta de definição, duas ilações relevantes merecem ser destacadas. Primeira, a de que é possível considerar uma empresa familiar que ainda não passou por um processo de sucessão. Nesse sentido, não partilhamos a perspetiva de se utilizar o critério da ocorrência de uma geração como condição para se definir a empresa familiar, enquanto critério exclusivo per si. Pelo contrário, podemos ter empresas com idades distintas preparadas ou não para a sucessão, planeando-a através de um protocolo familiar (Costa, Rio \& Rio, 2011).

A segunda ilação resulta de ser possível contemplar neste leque de empresas familiares os proprietários individuais em regime de autoemprego desde que a empresa tenha personalidade jurídica, permitindo que a mesma possa ser legalmente transferida.

\subsubsection{BD Roadmapef}

A aproximação ao objeto de estudo realiza-se a partir de uma recolha o mais exaustiva possível das fontes documentais e estatísticas complementares disponíveis para o mapeamento de empresas familiares na região Norte. Pretendia-se, assim, nesta primeira fase do projeto, a construção de uma base de dados de EFs, partir da qual se iria aplicar um questionário para melhor caraterizar os perfis das empresas familiares. Em concreto, esta etapa exigiu:

1. pesquisa documental de sistematização de estudos, legislação e documentos de referência no contexto nacional e internacional, no sentido de estabilização do conceito de Empresa Familiar a usar no âmbito do presente estudo;

2. sinalização de potenciais fontes de informação sobre empresas, cruzando diversos meios como, por exemplo, consulta do Portal da Justiça, IES (Informação Empresarial Simplificada)/ Ministério da Justiça: SICAE 
(Sistema de Informação da Classificação Portuguesa de Actividades Económicas) $)^{5} \mathrm{e}$ contactos disponibilizados pela Associação Empresarial de Portugal (AEP).

Dada a centralidade do "indicador" de empresa familiar disponibilizado por entidade credenciada $^{6}$, importa referir que o mesmo foi criado considerando entidades privadas e com capital social detido maioritariamente por pessoas individuais e não por sociedades ou por organismos públicos. Igualmente foram contempladas apenas duas formas jurídicas, designadamente sociedades por quotas de responsabilidade limitada e as sociedades anónimas ${ }^{7}$.

Neste esforço de identificação de empresas familiares, considerou-se, então, as empresas participadas por pessoas com participação no capital (quotas/ações) e as pessoas com cargos de gestão de topo (gerência/administração), permitindo distinguir 3 "grupos" de "Empresas Familiares": i) aquelas em que a "família" detém o controlo por via da participação no capital por um casal; ii) aquelas em que a "família" detém o controlo por via da participação no capital por familiares; iii) e aquelas em que a "família" detém o controlo através dos cargos de gestão/administração.

Estabilizado o conceito de empresa familiar a usar neste estudo e os elementos que a permite identificar, foi possível ir construindo a base de dados de empresas familiares da região Norte. Em termos operacionais, esta resultou do cruzamento proveniente de fontes diversificadas a que a equipa do projeto recorreu durante as suas várias etapas, tais como:

\section{* "Indicador" Empresa Familiar de entidade credenciada ${ }^{8}$; \\ * Contactos da Associação Empresarial de Portugal (AEP); \\ * Questionário às EFs da região Norte (online e presencial)}

Os campos de informação que integram a presente base de dados são de natureza fixa e de atualização anual. A informação fixa reporta-se à identificação da empresa familiar com o preenchimento dos seguintes elementos (sempre que disponíveis): número de contribuinte; nome da empresa; localização: morada da empresa, localidade, código postal (7 dígitos), endereço postal, freguesia, concelho, distrito; contactos: telefone, fax, email geral, website; data de constituição e de início de atividade; forma jurídica; CAE principal e seu descritivo e órgãos de gestão e administração. Quanto à informação atualizável anualmente, esta reporta-se aos elementos sujeitos a variações, como, por exemplo, número de trabalhadores, volume de negócios e peso de exportações.

\footnotetext{
5 A Informação Empresarial Simplificada (IES) constitui um sistema de dados que integra todas as empresas não-financeiras portuguesas que têm a obrigação de reportarem anualmente informação contabilística detalhada, bem como informações sobre outras variáveis relevantes, nomeadamente a forma jurídica da empresa.

60 recurso a consultores especialistas nesta área constituiu uma importante alavanca na prossecução das atividades subsequentes à criação de uma base de dados sobre empresas familiares.

7 Neste aspeto específico, o presente estudo incluiu outras formas jurídicas, nomeadamente a de empresário em nome individual e sociedades unipessoais por quotas, aproximando-se do entendimento do Grupo de Peritos da União Europeia (2009) atrás explicitado.

8 Representa 41.049 empresas familiares com informação válida em termos de informação disponível à época do estudo. Do cruzamento com outras iniciativas no trabalho de campo, foi possível acrescentar mais 437 elementos decorrente tanto dos contactos da AEP, como do questionário aplicado presencialmente, totalizando o número de 41.496 empresas familiares à data de abril de 2018.
} 


\subsubsection{Questionário EFs região Norte}

A aplicação de um questionário (online e presencial) às empresas familiares, que integram a nossa base de dados, constituiu no passo subsequente do projeto ao permitir sinalizar perfis desta tipologia empresarial (Bryman \& Cramer, 2003).

O plano de amostragem orientou-se pela representatividade da distribuição das empresas familiares por NUTS III e por dimensão da empresa definida por número de trabalhadores (Tabela 1). Por questões de simplificação do processo de recolha, foram considerados apenas três grupos de empresas em função do número de trabalhadores: empresas de menor dimensão (até 10 trabalhadores), empresas de dimensão intermédia (de 10 a 49 trabalhadores) e empresas de maior dimensão (50 ou mais trabalhadores).

TABELA 1. Distribuição de EFs por NUTS III e $n^{\circ}$ de trabalhadores

\begin{tabular}{|c|c|c|c|c|c|c|}
\hline \multirow{2}{*}{ NUTS III } & & \multicolumn{5}{|c|}{$\mathbf{N}^{\circ}$ de trabalhadores (agregado) ${ }^{9}$} \\
\hline & & Até 10 & De 10 a 49 & 50 ou mais & Subtotal & Total \\
\hline \multirow[t]{2}{*}{ Alto Minho } & $N$ & 1.656 & 305 & 33 & 1.994 & 2.332 \\
\hline & $\%$ & 83.0 & 15.3 & 1.7 & 85.5 & 5.7 \\
\hline \multirow[t]{2}{*}{ Alto Tâmega } & $\mathrm{N}$ & 515 & 85 & 8 & 608 & 729 \\
\hline & $\%$ & 84.7 & 14.0 & 1.3 & 83.4 & 1.8 \\
\hline \multirow{2}{*}{$\begin{array}{l}\text { Área Metropolitana } \\
\text { do Porto }\end{array}$} & $\mathrm{N}$ & 15.077 & 2.738 & 439 & 18.254 & 21.221 \\
\hline & $\%$ & 82.6 & 15.0 & 2.4 & 86.0 & 51.7 \\
\hline \multirow[t]{2}{*}{ Ave } & $\mathrm{N}$ & 3.203 & 803 & 177 & 4.183 & 4.769 \\
\hline & $\%$ & 76.6 & 19.2 & 4.2 & 87.7 & 11.6 \\
\hline \multirow[t]{2}{*}{ Cávado } & $\mathrm{N}$ & 3419 & 841 & 150 & 4.410 & 5.152 \\
\hline & $\%$ & 77.5 & 19.1 & 3.4 & 85.6 & 12.5 \\
\hline \multirow[t]{2}{*}{ Douro } & $N$ & 1.363 & 185 & 17 & 1.565 & 1.830 \\
\hline & $\%$ & 87.1 & 11.8 & 1.1 & 85.5 & 4.5 \\
\hline \multirow[t]{2}{*}{ Tâmega e Sousa } & $N$ & 2.638 & 716 & 166 & 3.520 & 4.083 \\
\hline & $\%$ & 74.9 & 20.3 & 4.7 & 86.2 & 9.9 \\
\hline \multirow[t]{2}{*}{ Terras de Trás-os-Montes } & $N$ & 722 & 89 & 5 & 816 & 943 \\
\hline & $\%$ & 88.5 & 10.9 & 0.6 & 86.5 & 2.3 \\
\hline \multirow[t]{2}{*}{ Total } & N & 28.593 & 5.762 & 995 & 35.350 & 41.059 \\
\hline & $\%$ & 80.9 & 16.3 & 2.8 & 86.1 & \\
\hline
\end{tabular}

Nota: O subtotal representa o total de empresas com número de trabalhadores conhecidos. A diferença entre o total e o subtotal corresponde ao número de empresas para as quais não se conhece o número de trabalhadores.

9 Nesta etapa de constituição da amostra pretendida para a aplicação do questionário, privilegiou-se apenas a informação disponibilizada do "indicador" empresa familiar da entidade credenciada mobilizada neste estudo. 
Para a definição da dimensão da amostra, teve-se em consideração um nível de confiança de $95 \%$ e uma margem de erro máxima de $3 \%$, o que determinou uma amostra constituída por 1040 empresas. Tomando em consideração as duas dimensões, optou-se por distribuir a amostra proporcionalmente pelas áreas geográficas e, dado o elevado número de empresas de menor dimensão e o reduzido número de empresas de maior dimensão, a amostra foi distribuída não proporcionalmente pelo número de trabalhadores, tal como se evidência na tabela seguinte (Tabela 2).

TABELA 2. Distribuição da amostra pretendida por NUTS III e dimensão

\begin{tabular}{|c|c|c|c|c|c|}
\hline \multirow{2}{*}{ NUTS III } & & \multicolumn{4}{|c|}{$\mathbf{N}^{\circ}$ de trabalhadores (agregado) } \\
\hline & & Até 10 & De 10 a 49 & 50 ou mais & Total \\
\hline \multirow[t]{2}{*}{ Alto Minho } & $\mathrm{N}$ & 33 & 16 & 10 & 59 \\
\hline & $\%$ & 55.9 & 27.1 & 16.9 & 5.7 \\
\hline \multirow[t]{2}{*}{ Alto Tâmega } & $N$ & 11 & 5 & 3 & 19 \\
\hline & $\%$ & 57.9 & 26.3 & 15.8 & 1.8 \\
\hline Área Metropolitana & N & 316 & 128 & 94 & 538 \\
\hline do Porto & $\%$ & 58.7 & 23.8 & 17.5 & 51.7 \\
\hline \multirow[t]{2}{*}{ Ave } & $N$ & 59 & 34 & 28 & 121 \\
\hline & $\%$ & 48.8 & 28.1 & 23.1 & 11.6 \\
\hline \multirow[t]{2}{*}{ Cávado } & $N$ & 66 & 35 & 29 & 130 \\
\hline & $\%$ & 50.8 & 26.9 & 22.3 & 12.5 \\
\hline \multirow[t]{2}{*}{ Douro } & $N$ & 73 & 13 & 6 & 47 \\
\hline & $\%$ & 59.6 & 27.7 & 12.8 & 4.5 \\
\hline \multirow[t]{2}{*}{ Tâmega e Sousa } & $\mathrm{N}$ & 49 & 29 & 26 & 103 \\
\hline & $\%$ & 47.6 & 28.2 & 25.2 & 9.9 \\
\hline \multirow[t]{2}{*}{ Terras de Trás-os-Montes } & $\mathrm{N}$ & 15 & 6 & 3 & 24 \\
\hline & $\%$ & 62.5 & 25.0 & 12.5 & 2.3 \\
\hline \multirow[t]{2}{*}{ Total } & $\mathrm{N}$ & 575 & 266 & 199 & 1040 \\
\hline & $\%$ & 55.3 & 25.6 & 19.1 & \\
\hline
\end{tabular}

Nota: Amostra para um nível de confiança de $95 \%$, com um erro máximo de $3 \%$. 
A informação recolhida sobre empresas familiares na região Norte, por via do questionário, orientou-se para as dimensões e indicadores mais relevantes neste estudo, designadamente:

i) registo genérico da empresa com a inclusão de variáveis de caraterização, tais como: principais produtos/ serviços da empresa; volume e mercados de exportação; fontes de financiamento, número de trabalhadores por sexo, evolução e recrutamento de trabalhadores, práticas de avaliação de desempenho, envolvimento em processos de inovação, certificação de qualidade e políticas de preservação ambiental, balanço de pontos fortes e principais fatores críticos da empresa familiar;

ii) estrutura e governação da empresa familiar, com informação sobre: geração da empresa, fundadores e razões da criação da empresa, capital social e distribuição pelos elementos familiares, composição da gerência (executivos e não executivos) por sexo, laços de parentescos e funções;

iii) profissionalização das famílias empresárias com informação relacionada com questões de sucessão, liderança e os principais desafios/ especificidades da relação família e negócio;

caraterização sociobiográfica do respondente ao questionário (próprio fundador ou gestor com conhecimento geral da empresa familiar).

Para a aplicação do questionário foi utilizada a plataforma LimeSurvey, tendo sido utilizados três processos distintos para a recolha das respostas ao questionário, os quais são identificados a seguir de forma sumária.

Entre os meses de junho e julho de 2017 foram enviados convites às empresas familiares referenciadas na base de dados com o indicador "Empresa Familiar". Neste período foram efetuados vários contactos às empresas familiares e dada a progressiva redução de respostas nas duas últimas semanas, este processo de recolha foi encerrado ${ }^{10}$.

Simultaneamente, estava disponível a recolha de respostas ao registo e preenchimento do questionário através do site www.roadmapef.ics.uminho. pt, opção esta que se mantém aberta permanentemente. Nesta fase de preenchimento, foram relevantes também os contactos sinalizados pela AEP, co-promotora do projeto, junto das empresas associadas que se declararam empresas familiares. Apesar dos esforços contínuos ${ }^{11}$, obtiveram-se apenas 180 respostas até ao encerramento da recolha de respostas ao questionário.

Perante estes resultados, foi necessário incluir uma fase presencial de aplicação dos questionários às empresas familiares. Esta decorreu entre outubro de 2017 a fevereiro 2018, o que permitiu

10 No total de cinco contactos distribuídos temporalmente pelos seguintes momentos: um contacto inicial, através de um convite enviado a 22 de junho, e quatro lembretes enviados com uma semana de diferença, nos dias 29 de junho, 4, 10 e 18 de julho. Depois de 129 respostas obtidas após o convite inicial, entraram nas semanas seguintes, 75 na segunda semana, 108 na terceira semana, 70 na quarta semana e 25 na quinta semana, num total de 407 respostas recebidas.

11 Nos meses junho e julho de 2017, obtiveram-se 94 respostas, tendo este valor sido bastante mais reduzido nos períodos seguintes do mesmo ano: 16 em setembro e outubro, 13 em novembro e dezembro (no mês de agosto não entrou qualquer resposta). Nos primeiros meses de 2018, janeiro e fevereiro, obtiveram-se 57 respostas, totalizando 180 respostas até ao encerramento da recolha de respostas ao questionário. 
fazer crescer esta recolha em mais 608 empresas familiares. Em síntese, entre junho de 2017 e fevereiro de 2018, o que equivaleu a 9 meses de trabalho intensivo no terreno, foram recolhidos, no total, 1.195 questionários.

Foram detetadas algumas situações anómalas, nomeadamente: mais de uma resposta ao questionário pela mesma empresa; respostas de empresas fora da delimitação geográfica desta recolha, quer por se tratar de empresas de outras regiões do país, quer de empresas não nacionais, e, finalmente, algumas respostas com informação totalmente inconsistente. Eliminadas estas situações foram validadas as respostas proporcionadas a 1.148 questionários.
A distribuição da amostra final pode ser observada na tabela seguinte (Tabela 3), a qual representa proporcionalmente as empresas familiares em cada uma das NUTS III. Para todos os efeitos, atendendo aos nossos objetivos de estudo, foi possível assegurar a constituição de uma amostra robusta em termos de representatividade do universo-alvo, garantindo um nível de confiança de $95 \%$, com um erro máximo de 3\%.

Para a análise dos dados recolhidos através do questionário disponibilizado na plataforma Lime Survey foi utilizado o programa IBM SPSS Statistcs (versão 24), após conversão do ficheiro de dados gerado pela plataforma, efetuando-se tratamentos estatísticos adequados aos objetivos do estudo.

TABELA 3. Distribuição da amostra final por NUTS III e dimensão

\begin{tabular}{|c|c|c|c|c|c|c|}
\hline \multirow[b]{2}{*}{ NUTS III } & & \multicolumn{5}{|c|}{$\mathbf{N}^{\circ}$ de trabalhadores } \\
\hline & & $\begin{array}{c}\text { Micro } \\
\leq 3\end{array}$ & $\begin{array}{l}\text { Micro } \\
(4-9)\end{array}$ & $\begin{array}{l}\text { Pequend } \\
(10-49)\end{array}$ & $\begin{array}{l}\text { Média e } \\
\text { Gronde } \\
\text { Empresa } \\
(\geq 50)\end{array}$ & Total \\
\hline \multirow[t]{2}{*}{ Alto Minho } & $\mathrm{N}$ & 10 & 28 & 20 & 9 & 67 \\
\hline & $\%$ & 14.9 & 41.8 & 29.9 & 3.4 & 5.8 \\
\hline \multirow[t]{2}{*}{ Alto Tâmega } & $N$ & 2 & 10 & 6 & 3 & 21 \\
\hline & $\%$ & 9.5 & 47.6 & 28.6 & 14.3 & 1.8 \\
\hline Área Metropolitana & $\mathrm{N}$ & 200 & 146 & 142 & 55 & 543 \\
\hline do Porto & $\%$ & 36.8 & 26.9 & 26.2 & 10.1 & 47.3 \\
\hline \multirow[t]{2}{*}{ Ave } & $N$ & 25 & 40 & 45 & 28 & 138 \\
\hline & $\%$ & 18.1 & 29.0 & 32.6 & 20.3 & 12.0 \\
\hline \multirow[t]{2}{*}{ Cávado } & $\mathrm{N}$ & 45 & 56 & 59 & 29 & 189 \\
\hline & $\%$ & 23.8 & 29.6 & 31.2 & 15.3 & 16.5 \\
\hline \multirow[t]{2}{*}{ Douro } & $\mathrm{N}$ & 16 & 18 & 13 & 6 & 53 \\
\hline & $\%$ & 30.2 & 34.0 & 24.5 & 11.3 & 4.6 \\
\hline \multirow[t]{2}{*}{ Tâmega e Sousa } & $\mathrm{N}$ & 25 & 28 & 34 & 23 & 110 \\
\hline & $\%$ & 22.7 & 25.5 & 30.9 & 20.9 & 9.6 \\
\hline \multirow[t]{2}{*}{ Terras de Trás-os-Montes } & $\mathrm{N}$ & 3 & 14 & 8 & 2 & 27 \\
\hline & $\%$ & 11.1 & 51.9 & 29.6 & 7.4 & 2.4 \\
\hline \multirow[t]{2}{*}{ Total } & $\mathrm{N}$ & 326 & 340 & 327 & 155 & 1148 \\
\hline & $\%$ & 28.4 & 29.6 & 28.5 & 13.5 & \\
\hline
\end{tabular}




\subsection{Enfoque qualitativo - Testemunhos de empresário(a)s}

Neste enfoque qualitativo, destaca-se, sobretudo, a realização de entrevistas aprofundadas a empresário(a)s familiares nos contextos das respetivas organizações. Para além de esta atividade se justificar como suporte à conceção do questionário, com a sinalização das questões a formular, permitiu reconstruir a "história" e "cultura" da empresa familiar e redes de parentesco, recuperar a trajetória do(a)s fundador(a)s, principais momentos críticos de viragem/ readaptação/ transformação do negócio, bem como questões relacionadas com a situação presente e os desafios para o futuro. Esta atividade assentou num guião semiestruturado de apoio à condução da entrevista sujeita a gravação áudio e com uma duração média de 1h:30.

Os critérios utilizados na seleção de empresário(a)s a entrevistar partiram sobretudo dos contactos estabelecidos nos workshops e eventos presenciais e da disponibilidade dos mesmos em aceitarem o convite. Da aproximação ao terreno, procurou-se assegurar a diversidade desta tipologia empresarial. Assim, como critérios de segmentação, refiram-se seguintes: i) distribuição territorial ao nível das NUTS III; ii) dimensão da empresa (em função do número de trabalhadores declarado); iii) antiguidade da empresa; iv) e setor de atividade.

No total, foram realizadas 23 entrevistas, com dimensões e setores de atividades diversificados e pertencendo a diversas gerações. Esta atividade constituiu-se numa oportunidade para se visitar a maior parte das empresas familiares e registar a informação decorrente da observação e interação entre diversos membros familiares e não familiares.

Para o tratamento do conteúdo das entrevistas, recorreu-se ao software MAXQDA (versão 12). Este programa permite ao investigador gerir, dar forma e sentido à informação não estruturada. Com este programa, é possível realizar um vasto conjunto de ações que facilita a tarefa de análise do material, identificação das categorias, reflexão e desenvolvimento de conclusões (Creswell \& Clark, 2017; Tesch, 2013).

\subsection{Enfoque participativo - (Auto) Reflexividade}

Do conjunto das atividades desenvolvidas neste enfoque participativo, destaca-se a organização do ciclo de worskhops direcionado para empresas familiares, com lugar em cada uma das NUTS III da região Norte, para além da participação de empresário(a)s e especialistas nos seminários internacionais que tiveram lugar no decorrer do projeto. Este ciclo decorreu entre maio 2017 a fevereiro $2018^{12}$ e foi realizado em cada uma das NUTS III da região Norte e subordinado à temática transversal "Empresas Familiares: Enfrentar os Desafios Assegurar a Continuidade".

Nos oito workshops distribuídos pela Área Metropolitana do Porto, Alto Minho, Cávado, Ave, Tâmega e Sousa, Douro, Alto Tầmega e Terras de Trás-os-Montes, foram convidados empresários tendo em conta a região e o predomínio do setor de atividade. Em cada um dos workshops estiveram envolvidos, em média, entre 12 a 20 empresários(a)s familiares.

12 Apesar dos esforços da equipa do projeto, o workshop relativo à NUT III do Alto Tâmega realizou-se a 3 de Julho 2018. Dificuldades de disponibilidade e articulação de agendas dos diferentes interlocutores justificaram que o mesmo tenha sido realizado fora do período previsto na calendarização das atividades do projeto. 
Foi possível sistematizar várias temáticas, a partir dos testemunhos de empresário(a)s que participaram, em especial, no que diz respeito à questão da sucessão da empresa, da profissionalização do negócio, da feminização dos líderes, dos conflitos família e negócio, da continuidade da empresa sob o controlo da família e coesão familiar. Quanto à questão "sensível" da sucessão, a ferramenta do "protocolo familiar" afigura-se com potencial efetivo para o planeamento da passagem de "testemunho" para a geração seguinte, contribuindo para as boas práticas do seu governo, a continuidade da empresa sob o controlo da família e a própria coesão familiar.

Na discussão desta temática transversal aos vários workshops, destaca-se a importância da "voz" das empresas familiares na sinalização de preocupações e desafios comuns, particularmente tendo em conta a emergência de uma nova geração de empresário(a)s mais qualificado(a)s e atuando em mercados competitivos e globais. Esta dinâmica coletiva de partilha e discussão de tópicos internos da família empresária e a relevância da voz na sinalização das preocupações, desafios e boas práticas comuns, transformou este espaço formativo também numa experiência de (auto) reflexividade dos próprios intervenientes no processo. Potenciou maior visibilidade das empresas familiares e seu papel no contributo para a economia e sociedade, bem como se sinalizaram as respetivas "especificidades" desta tipologia empresarial. 



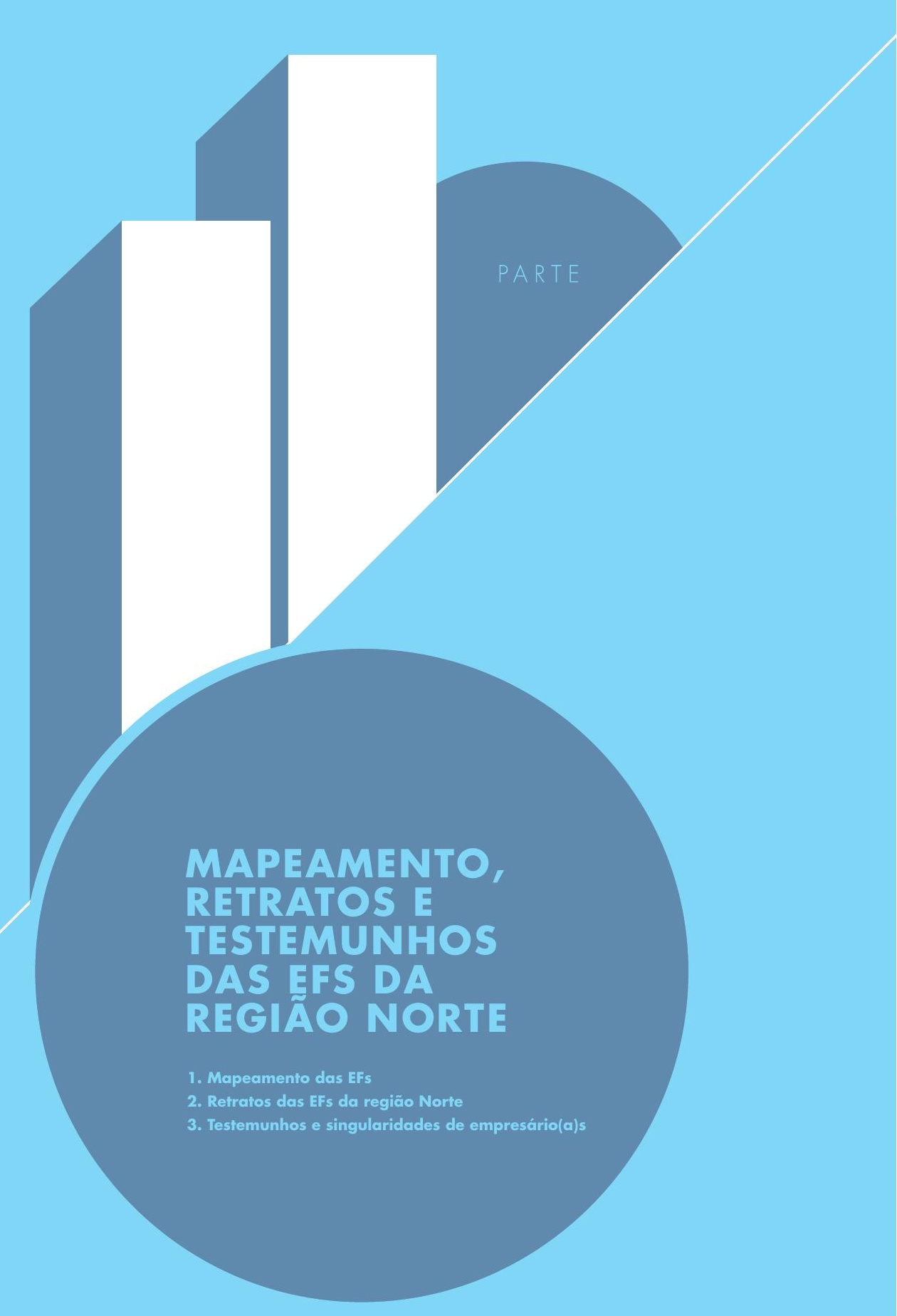





\section{As empresas são transversais na economia, existem em todos os sectores de atividade, não se restringindo a pequenas e médias empresas (PME), ainda que esta seja a tipologia dominante. Apresenta-se, de seguida, a informação recolhida tanto no mapeamento, como no questionário online e presencial dirigido às empresas familiares da região Norte. Finaliza-se, este relatório, com os testemunhos de empresários(a)s que aceitaram partillhar memórias, experiências e projetos de vida.}

\section{Mapeamento das EFs}

As empresas familiares constituem a base predominante do tecido empresarial da maioria dos países, sendo inegável a representatividade desta forma empresarial na economia e sociedade. A Base de Dados Roadmapef (BD Roadmapef) representa cerca de $10,4 \%$ das empresas classificadas pelo INE ${ }^{13}$ como sedeadas no Norte de Portugal (Gráfico 1), sendo que, sempre que disponível e considerado adequado, se apresentarão dados comparativos destas duas realidades em contexto nacional e internacional.

Inicia-se por explorar os principais indicadores de caracterização das EFs mapeadas na região Norte, designadamente a distribuição pelas sub-regiões administrativas do Norte, dimensão de EFs por número de trabalhadores (sexo masculino e feminino), antiguidade, natureza jurídica, setores de atividade económica (CAE), volume de negócios e peso das exportações.
GRÁFICO 1. Representatividade

da BD Roadmapef no Norte

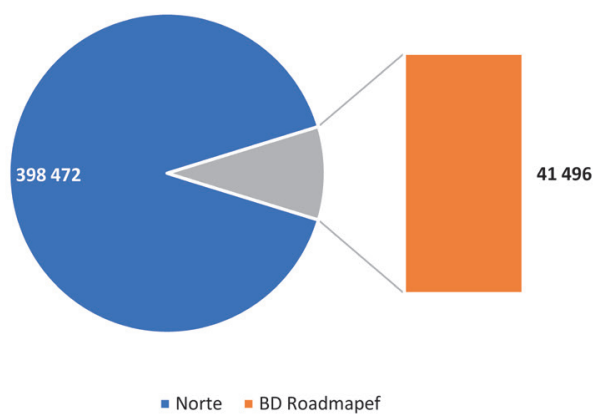

Fonte: BD Roadmapef e INE Indicadores Económicos e Patrimoniais das Empresas não Financeiros em Portugal, 2008-2016, 2018

\subsection{Quantas e onde se localizam as EFs?}

Na região Norte, caraterizada por uma forte dinâmica empresarial, importa saber quantas são as empresas familiares e onde se encontram 
localizadas. Da análise da BD Roadmapef, mais de metade das empresas familiares localiza-se na sub-região Área Metropolitana do Porto, seguida, com pesos relativos substancialmente mais reduzidos, pelas sub-regiões do Cávado, Ave, Tâmega e Sousa e Alto Minho. Com percentagens claramente residuais, com valores abaixo dos $5 \%$, surgem nas sub-regiões do Douro, Terras de Trás-os-Montes e Alto Tầmega (Tabela 4 e Gráfico 2).

TABELA 4. Distribuição das EFs por NUTS III (2017)

\begin{tabular}{|l|r|r|}
\hline NUTS III & \multicolumn{1}{|c|}{ N } & \multicolumn{1}{c|}{$\%$} \\
\hline Alto Minho & 2.350 & 5,7 \\
\hline Alto Tâmega & 738 & 1,8 \\
\hline Área Metropolitana do Porto & 21.421 & 51,6 \\
\hline Ave & 4.815 & 11,6 \\
\hline Cávado & 5.224 & 12,6 \\
\hline Douro & 1.848 & 4,5 \\
\hline Tâmega e Sousa & 4.116 & 9,9 \\
\hline Terras de Trás-os-Montes & 949 & 2,3 \\
\hline S/ informação & 35 & 0,1 \\
\hline \multicolumn{1}{|c|}{ Total } & $\mathbf{4 1 4 9 6}$ & $\mathbf{1 0 0 , 0}$ \\
\hline
\end{tabular}

Fonte: BD Roadmapef.

\section{GRÁFICO 2. Distribuição das EFs por NUTS III (2017) $(\mathrm{N}=41.496)$}

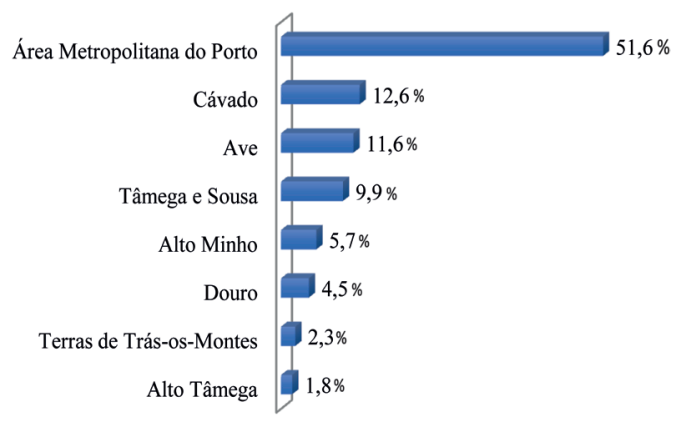

Fonte: BD Roadmapef.
Nas figuras seguintes, visualiza-se melhor a concentração de empresas familiares na faixa litoral Norte ao nível da NUTS III e dos municípios que as integram (Figuras 6 e 7).

\section{FIGURA 6. Distribuição das EFs da região Norte por NUTS III}

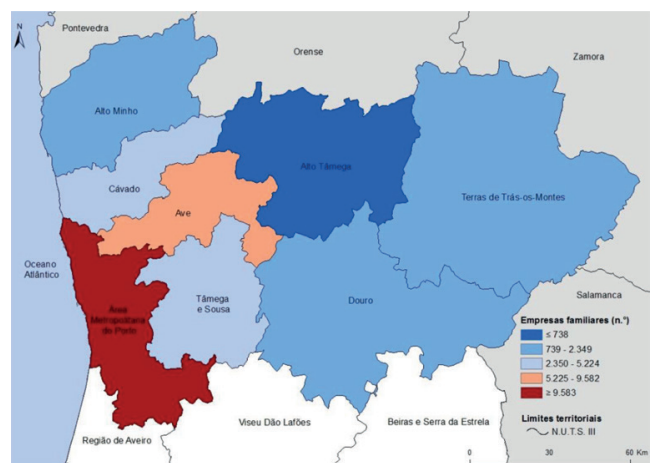

Fonte: BD Roadmapef.

\section{FIGURA 7. Distribuição das EFs da região Norte por municípios}

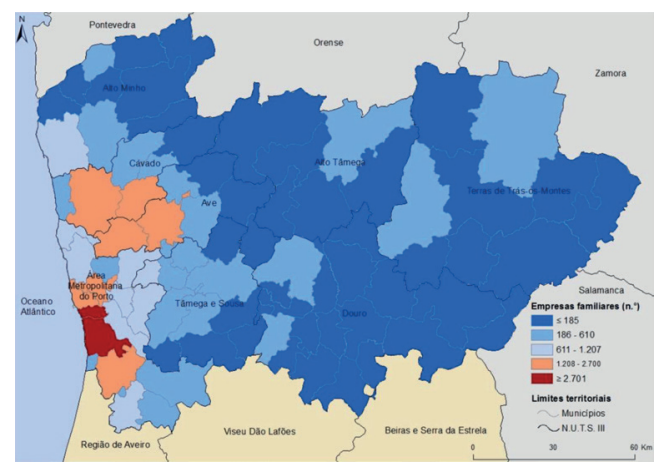

Fonte: BD Roadmapef.

Olhando para a distribuição das empresas familiares por municípios, estas concentram-se 
sobretudo no litoral e, em especial, na sub-região da Área Metropolitana do Porto (Gráfico 3). Dada a diversidade de concelhos que a integra, importa destacar os pesos relativos das empresas mapeadas sobretudo no concelho do Porto, seguido com grande distância pelo de Vila Nova de Gaia, Maia, Matosinhos e Santa Maria da Feira.

GRÁFICO 3. Distribuição das EFs pela Área Metropolitana do Porto

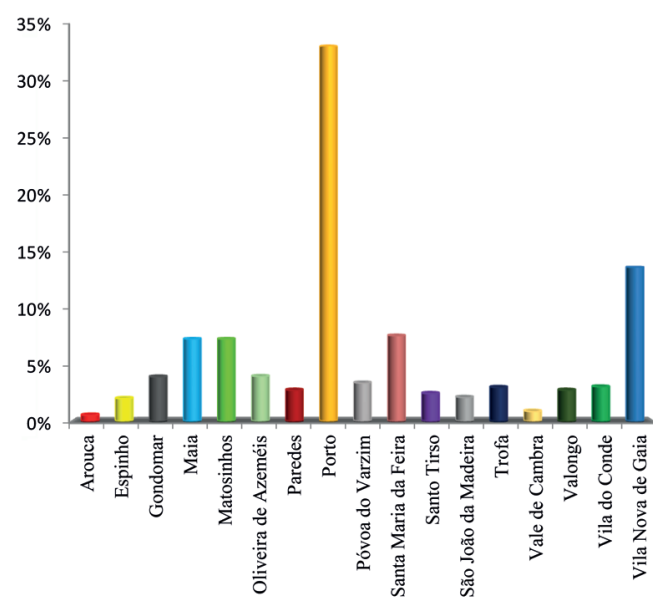

Fonte: BD Roadmapef.

Em situação intermédia, importa destacar as outras sub-regiões, em especial a do Cávado e Ave. Estas apresentam percentagens relativas próximas, em torno dos 12 a $13 \%$ das empresas familiares por nós mapeadas. Para o Cávado (Gráfico 4) assumem expressão muito significativa os municípios de Braga e Barcelos, sendo residuais os pesos de empresas familiares nos restantes.

Com uma distribuição algo semelhante acontece com Ave (Gráfico 5), com destaque para os municípios de Guimarães e de Vila Nova de Famalicão. Por sua vez a sub-região do Tầmega e Sousa (Gráfico 6) regista uma distribuição mais dispersa das empresas familiares mapeadas no conjunto dos seus 11 municípios, com destaque, ainda assim, para Paços de Ferreira, seguido de Felgueiras, Amarante e Penafiel (todos com percentagens idênticas).

\section{GRÁFICO 4. Distribuição das EFs pelo Cávado}

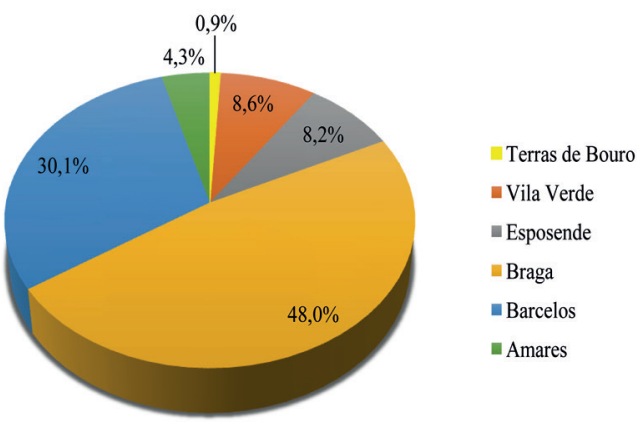

Fonte: BD Roadmapef.

GRÁAICO 5. Distribuição das EFs pelo Ave

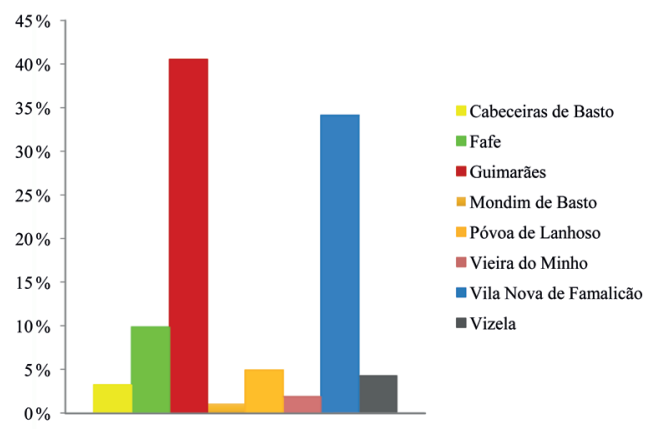

Fonte: BD Roadmapef. 
GRÁFICO 6. Distribuição das EFs pelo Tầmega e Sousa

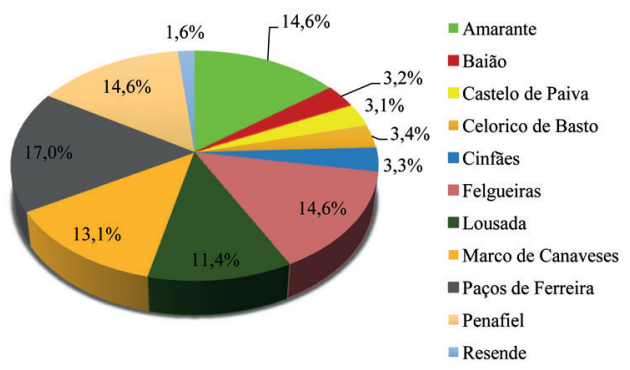

Fonte: BD Roadmapef.

A sub-região do Alto Minho (Gráfico 7) representa, no conjunto das oito NUTS III do Norte, apenas 5,7\% e cujo principal contributo decorre sobretudo dos municípios de Viana do Castelo e Ponte de Lima.

GRÁFICO 7. Distribuição das EFs pelo Alto Minho

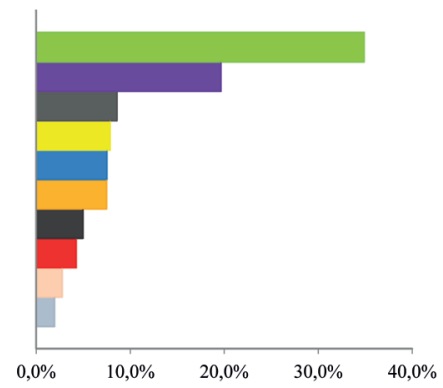

Viana do Castelo

- Ponte de Lima

valença

Caminha

- Arcos de Valdevez

Monção

- Ponte da Barca

- Vila Nova de Cerveira

m Paredes de Coura

Melgaço

Fonte: BD Roadmapef.

Por fim, as sub-regiões Douro, Terras de Trás-os Montes e Alto Tâmega são as que se encontram com menor expressão de empresas mapeadas. Do rendilhado de municípios do Douro (Gráfico 8) destaque para Vila Real, Lamego e Peso da Régua.
GRÁFICO 8. Distribuição das EFs pelo Douro

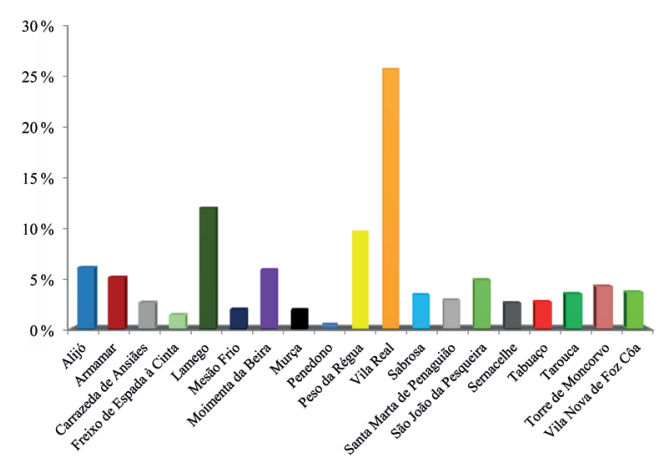

Fonte: BD Roadmapef.

Situação idêntica para as Terras de Trás-os-Montes (Gráfico 9) com particular destaque para Bragança, seguido por Mirandela e Macedo de Cavaleiros. Quanto ao Alto Tâmega (Gráfico 10) refira-se que Chaves regista quase metade de empresas familiares identificadas na nossa base de dados, seguida, com grande distância, por Valpaços e Vila Pouca de Aguiar.

\section{GRÁFICO 9. Distribuição das EFs pelas Terras de Trás-os-Montes}

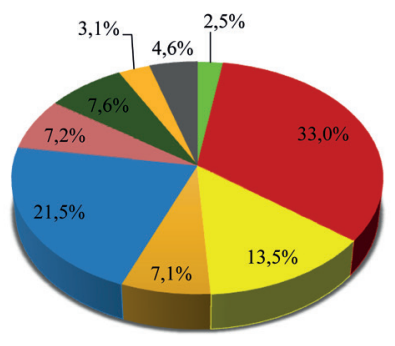

- Alfandega da Fé

- Bragança

Macedo de Cavaleiros - Miranda do Douro

- Mirandela

Mogadouro

- Vila Flor

Vimioso

vinhais

Fonte: BD Roadmapef. 


\section{GRÁFICO 10. Distribuição das EFs pelo Alto Tâmega}

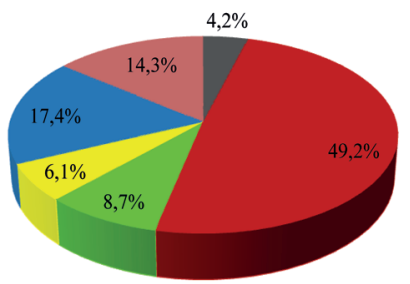

\section{Boticas}

n Chaves

- Montalegre

Ribeira de Pena

- Valpaços

- Vila Pouca de Aguiar

Fonte: BD Roadmapef.

A tendência de litoralização da atividade empresarial e, em especial nos municípios com maior densidade populacional, surge evidenciada no mapeamento das empresas familiares. Com efeito, o país confronta-se com uma dupla tendência de distribuição de grande concentração populacional no litoral do país, entre Braga e Setúbal, expressando um processo persistente de litoralização populacional, a par de um profundo despovoamento do interior de Portugal. Trata-se de uma distribuição estrutural desigual resultante da prevalência de fatores físicos, como, por exemplo, recursos do subsolo, clima, relevo, posição geográfica ${ }^{14}$; fatores humanos, designadamente de industrialização, terciarização, vias de comunicação, equipamentos sociais, entre outros; e fatores socio-históricos.

Este duplo processo provoca, no interior do país, uma desertificação humana,

agravamento do envelhecimento populacional, potenciando uma regressão económica, com o abandono dos campos e a diminuição do consumo. Por sua vez, a zona litoral do país conhece um crescimento descontrolado das áreas urbanas (especial suburbanas), com agravamento de situações de trânsito caótico, insegurança, rutura de equipamentos sociais nas áreas da saúde e educação, contribuindo, em grande medida, para uma deterioração da qualidade de vida para as populações que habitam nessas áreas. Compreende-se, por conseguinte, que a promoção da coesão territorial e social se constitua num dos eixos prioritários da atuação transversal nos domínios de investimento económico e político (educação, saúde e ação social) no quadro da Europa 2020 e do Acordo de Parceria Portugal.

\subsection{Qual a dimensão das EFs por número de trabalhadores?}

As $\mathrm{PME}^{15}$ constituem a base predominante da tipologia empresarial em Portugal e na Europa ${ }^{16}$. Segundo INE/ PORDATA, em 2016, estas representam 99,9\% do total da atividade económica, mantendo-se esse valor inalterável nos últimos 12 anos. Desta percentagem, são as micro empresas que contribuem com 95,4\%; e com percentagens residuais, as pequenas empresas (3,9\%) e médias $(0,6 \%)^{17}$.

\footnotetext{
14 Portugal Continental encontra-se ao mesmo nível que os países da Europa Ocidental e Central, ou seja, acima dos 100 habitantes por $\mathrm{km} 2$, sendo que as densidades mais baixas ocorrem no Leste e Norte da Europa, consequência de fatores de ordem física menos favoráveis, nomeadamente o clima mais rigoroso. Quanto à distribuição da população, esta acompanha a história do país, registando uma maior concentração de população no litoral do que no interior. Os contrastes regionais são notórios entre Grande Lisboa e Grande Porto, e densidades importantes em todo o litoral desde o norte (Minho e Lima) até ao Algarve, com única exceção do Alentejo litoral.

15 De acordo com a Recomendação da Comissão Europeia (2003/361/CE), a categoria agregadora de micro, pequenas e médias empresas é constituída por empresas que empregam menos de 250 pessoas e cujo volume de negócios anual não excede 50 milhões de euros ou cujo balanço total anual não excede 43 milhões de euros.

16 Nos 25 Estados-Membros da UE existem cerca de 23 milhões de PME que representam 99\% do total de empresas e empregam perto de 75 milhões de pessoas (COM, 2015).

17 Informação disponível em https://www.pordata.pt/ [Acesso a 22.05.2018].
} 
No contexto do mapeamento das empresas familiares da região Norte, a expressão das micro empresas que empregam até 9 trabalhadores segue a mesma tendência das empresas em geral. Com base na informação atual e disponível até ao momento, $10 \%$ das empresas familiares não registam nenhum trabalhador, sendo que $70,7 \%$ são micro empresas. Dado o peso relativo muito elevado das micro empresas no universo-alvo deste estudo e sabendo que as mesmas apresentam realidades e dinâmicas heterogéneas, optamos por subdividi-las em dois grupos: um grupo de empresas até três trabalhadores e um outro com 4 a 9 trabalhador. Muito significativa é a percentagem de pequenas empresas $(10 \mathrm{a}$
49 trabalhadores), com 16,3\%, mas também não despiciendo a presença de médias e grandes empresas familiares (Gráfico 11). Aliás, numa análise comparativa, entre as empresas da Base de Bados Roadmapef e as do Norte do país disponibilizada pelo INE ${ }^{18}$, regista-se uma diferença muito significativa quando classificadas pela dimensão do $n^{\circ}$ de trabalhadores: as pequenas e as médias e grandes empresas familiares são cerca de 4 a 5 vezes mais em número, em detrimento de micro-empresas ainda que seja visível o seu protagonismo nesta estrutura empresarial. Este mapeamento permite reforçar o argumento da heterogeneidade interna das empresas familiares.

GRÁFICO 11. EFs por número de trabalhadores $(\mathrm{N}=35.780)$

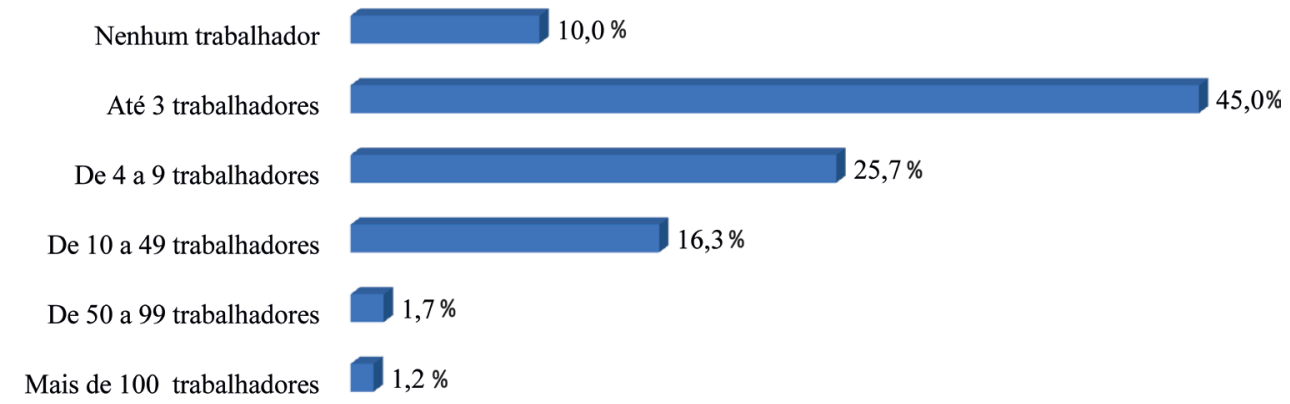

Fonte: BD Roadmapef

18 Consulte-se INE Indicadores Económicos e Patrimoniais das Empresas não Financeiros em Portugal, 2008-2016, 2018. 
Na distribuição dos trabalhadores por sexo, observa-se uma presença ligeiramente maior dos homens em função da dimensão da empresa familiar, quando comparado com os trabalhadores do sexo feminino (Gráficos 12 e 13). Ou seja, as empresas familiares de menor dimensão tendem a expressar um menor contributo do género feminino na força de trabalho, o que significa que, inversamente, se observa uma presença masculina proporcionalmente mais expressiva nas empresas familiares de maior dimensão.

Esta tendência poderá estar relacionada com os setores de atividade económica predominante em termos de dimensão como, por exemplo, as indústrias transformadoras e o setor da construção. Estes setores tendem a deter caraterísticas de médias e grandes empresas e revelam, simultaneamente, uma significativa segregação ocupacional por género, com os homens mais presentes neste tipo de atividade económica.

GRÁFICO 12. EFs por número de trabalhadores do sexo masculino ( $N=35.780$ )

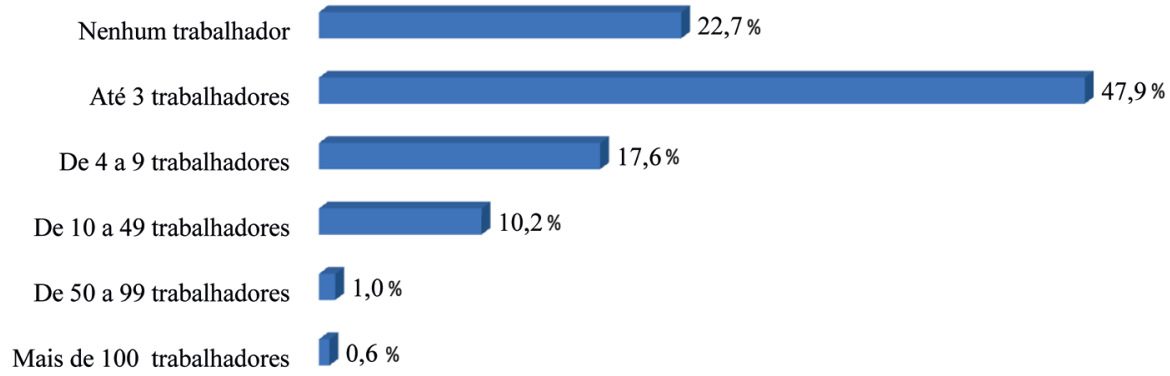

Fonte: BD Roadmapef.

GRÁFICO 13. EFs por número de trabalhadores do sexo feminino $(\mathrm{N}=35.780)$

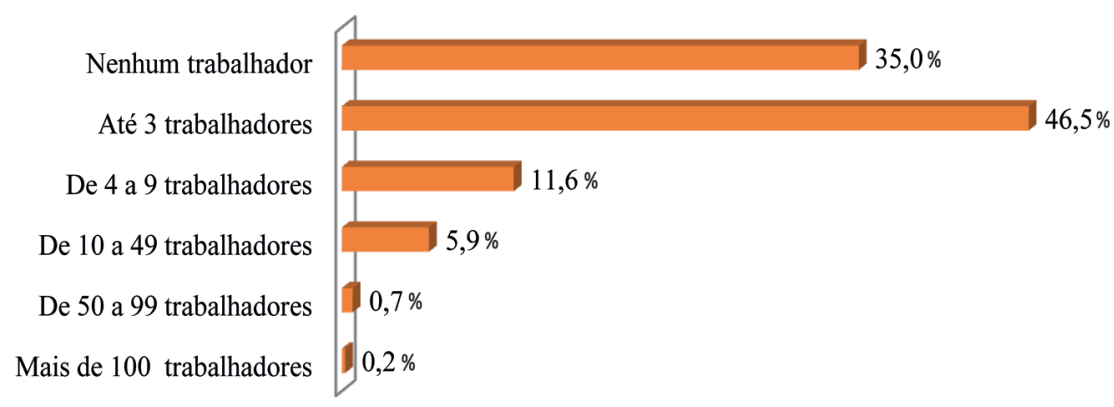

Fonte: BD Roadmapef 
Por sua vez, a feminização do mercado de trabalho registada nas últimas duas décadas em Portugal ilustra a entrada de mulheres em quase todos os setores de atividade, em especial, em empresas de maior dimensão (Figura 8). Aliás esta é uma das tendências mais significativas a se destacar na estrutura ocupacional quanto à questão da igualdade de género no mercado de trabalho em geral. Temática com diversos enfoques disciplinares, a crescente participação feminina no mercado de trabalho tem vindo a contribuir para uma alteração dos perfis e estrutura de empregos/ profissões, para além de mudanças de estilos de vida e padrões culturais com destaque para os países desenvolvidos e com relevo para os da União Europeia ${ }^{19}$. Um dos fatores que mais tem contribuído para esta transformação tem que ver com a elevação dos níveis de qualificação superior detida pelas mulheres.

\section{FIGURA 8. Feminização da força de trabalho das EFs}

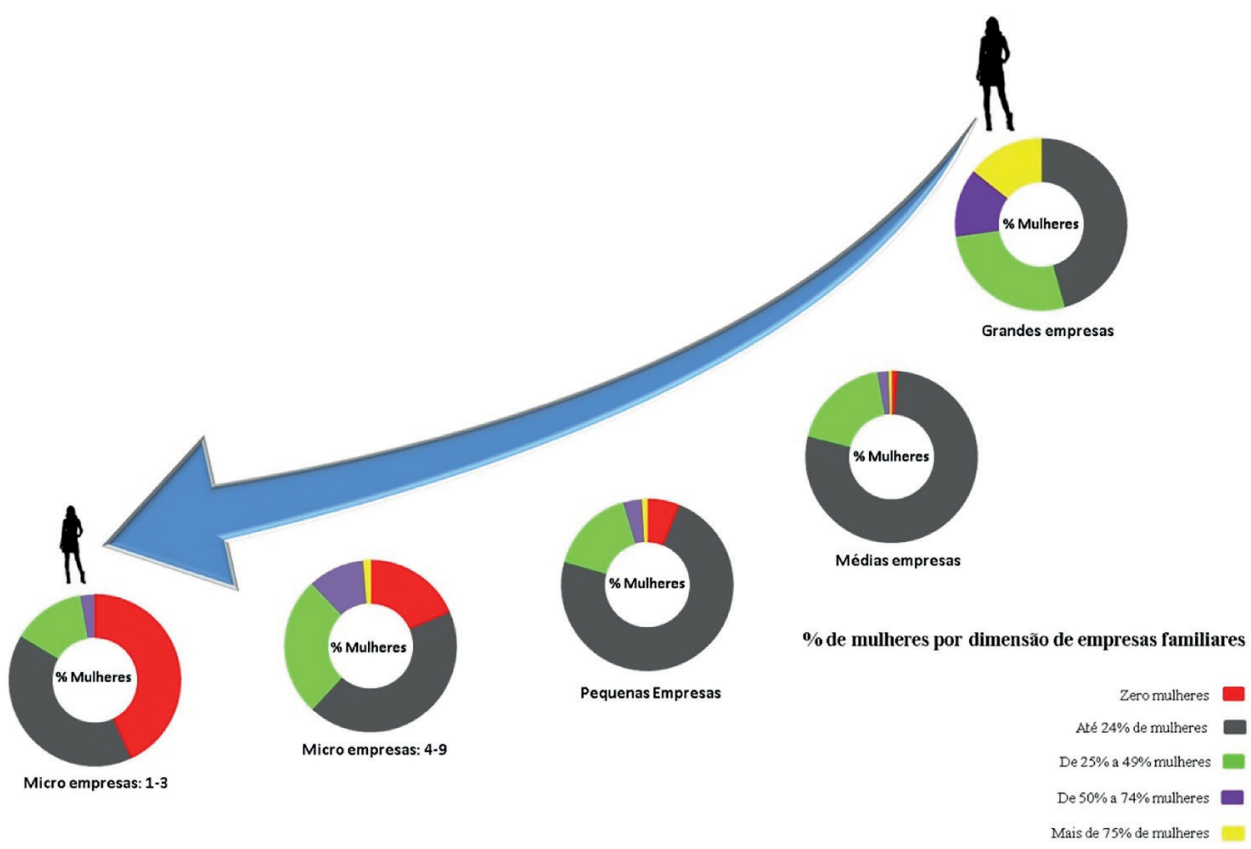

19 Que muito tem vindo a contribuir, em especial no plano das diretivas e recomendações para os países Membros, no sentido das mudanças legislativas para combater as desigualdades de género, dado o persistente gap salarial entre homens e mulheres e menores oportunidades de ascensão profissional e de ocupação de cargos de chefia por parte das mulheres. 


\subsection{Qual a antiguidade e regime jurídico das EFs?}

A resiliência das empresas, medida pelos anos de existência, constitui uma das dimensões importantes da capacidade económica de qualquer país. Mais, tende-se a associar à dinâmica empresarial a inovação e a criação de emprego. Destaque para a atividade empreendedora observável pelo registo anual de recém-novas empresas, em especial as que conseguem atingir a fase dos 3 anos e meio de vida, que traduz já a consolidação de um negócio $(G E M, 2013)^{20}$. Esta temporalidade remete-nos para a elevada vulnerabilidade das fases iniciais do ciclo de vida de um processo empreendedor ${ }^{21}$, explicando, em grande medida, a mortalidade precoce de muitos das empresas criadas.
No caso concreto da população portuguesa, reconhece-se nos últimos anos uma tendência de crescimento de novas empresas, registando-se no ano de 2015 um crescimento de $3 \%$ do número total de empresas (+ 34.252 empresas) face ao ano anterior, na sua maioria juridicamente de caráter individual (68\%).

Não obstante o elevado número de empresas que inicia atividade todos os anos, as novas empresas encerram a uma taxa significativa nos seus primeiros anos de vida ${ }^{22}$. Uma análise sobre a taxa de sobrevivência indica que uma significativa percentagem destas novas empresas tende a encerrar nos seus primeiros anos de vida, propensão identicamente visível na dinâmica empresarial dos demais países europeus (Gráfico 14).

\section{GRÁFICO 14. Taxa de sobrevivência das empresas por tempo de vida, na Europa em $2015^{23}$}

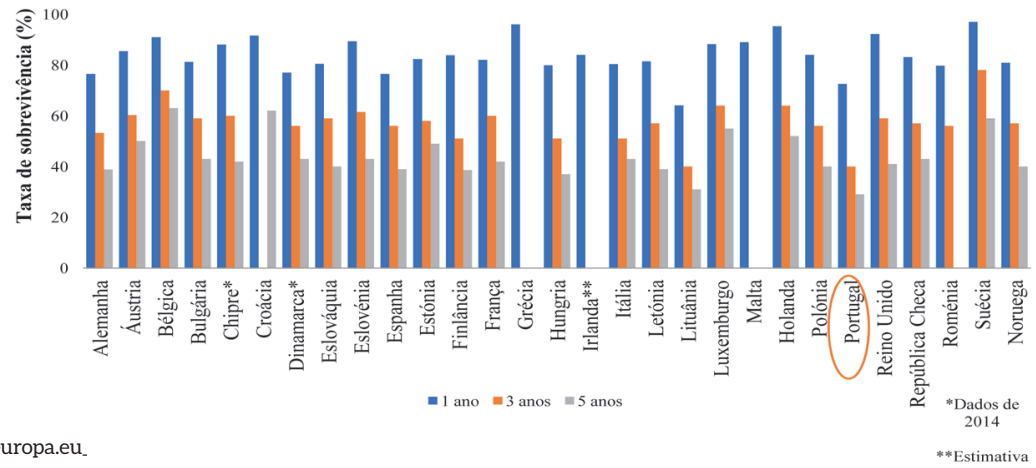

Fonte: www.ec.europa.eu

**Estimativa

\footnotetext{
20 Segundo o Global Entrepreneurship Monitor (GEM) o empreendedorismo é definido como "qualquer tentativa de criação de um novo negócio ou nova iniciativa, tal como emprego próprio, uma nova organização empresarial ou a expansão de um negócio existente, por parte de um indivíduo, de uma equipa de indivíduos, ou de negócios estabelecidos". Mais informação em www.gemconsortium.org.

21 Para o GEM, é possível identificar três fases: 1) empreendedores de negócios nascentes, com a mobilização de recursos para começar um negócio do qual esperam ser donos; 2) empreendedores de novos negócios, quando estes são donos e gerem um novo negócio que proporciona remuneração salarial por um período superior a 3 meses e inferior a 3,5 anos; 3) e empreendedores de negócios estabelecidos quando são donos e gerem um negócio já estabelecido e que está em funcionamento há mais de 3,5 anos (GEM, 2013).

22 De acordo com a literatura empírica sobre a sobrevivência de empresas, a saída de empresas é identificada como o encerramento da empresa. Assim, o momento da saída é identificado como o ano em que as empresas deixam de reportar informação à IES.
}

$23 \mathrm{http}: / /$ ec.europa.eu/eurostat/statistics-explained/index.php/Business_demography_statistics (Acesso a 15 de maio de 2018) 
Segundo Felix (2017: 37$)^{24}$, as taxas de sobrevivência de novas empresas portuguesas encontram-se em linha com a elevada mortalidade de novas empresas documentada na literatura empírica de organização industrial. Em Portugal, uma empresa nascida em 2015, a idade máxima atingida é de 8 anos e para uma empresa nascida em 2011 passa a ser de dois anos. Já quanto à criação de novas empresas, estas encerram com uma taxa próxima dos $50 \%$ antes de completarem sete anos de vida.

Pelo impacto que a sobrevivência de uma empresa tem em todas as partes interessadas - em especial nos sócios, empregados e comunidade envolvente -, merece uma análise mais detalhada deste indicador de perenidade (Gráficos 15 e 16).

\section{GRÁFICO 15. Taxa de sobrevivência das empresas}

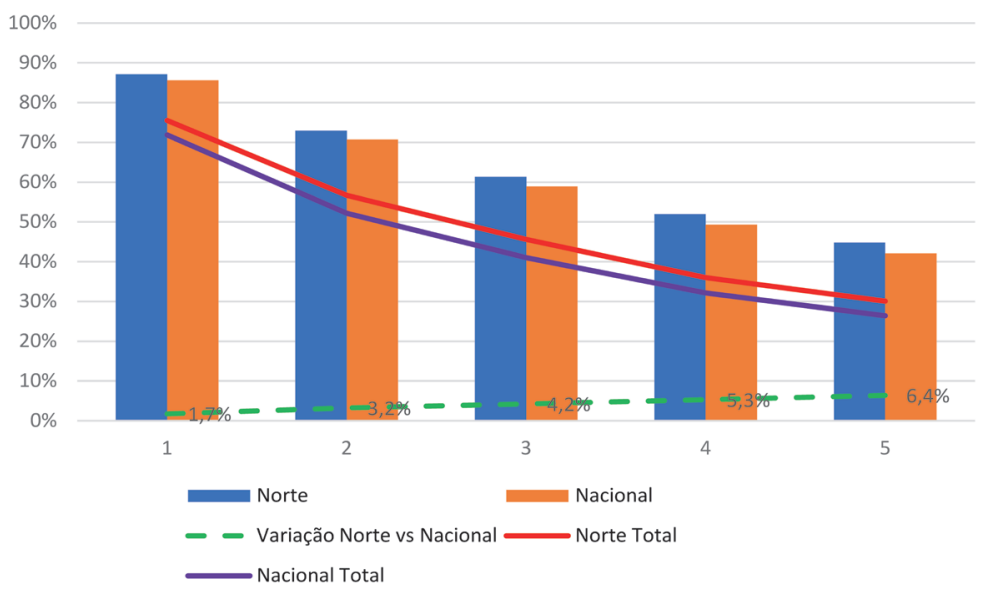

\begin{tabular}{|l|r|r|r|r|r|r|r|r|r|r|}
\hline $\begin{array}{c}\text { Taxas Médias de } \\
\text { Sobrevivência }\end{array}$ & \multicolumn{4}{|c|}{ Empresas que sobrevivem ao fim de: } & \multicolumn{3}{c|}{$\begin{array}{c}\text { Nascidas, com pelo menos } 1 \text { pessoa } \\
\text { remunerada, que sobrevivem ao fim de: }\end{array}$} \\
\hline Norte & 1 ano & 2 anos & 3 anos & 4 anos & 5 anos & 1 ano & 2 anos & 3 anos & 4 anos & 5 anos \\
\hline Nacional & $75,5 \%$ & $56,7 \%$ & $45,6 \%$ & $36,0 \%$ & $30,1 \%$ & $87,1 \%$ & $72,9 \%$ & $61,4 \%$ & $51,9 \%$ & $44,8 \%$ \\
\hline Diferença & $71,8 \%$ & $52,1 \%$ & $41,0 \%$ & $32,1 \%$ & $26,4 \%$ & $85,6 \%$ & $70,7 \%$ & $58,9 \%$ & $49,3 \%$ & $42,1 \%$ \\
\hline Variação Norte vs Nacional & $3,7 \%$ & $4,6 \%$ & $4,5 \%$ & $3,9 \%$ & $3,6 \%$ & $1,5 \%$ & $2,3 \%$ & $2,5 \%$ & $2,6 \%$ & $2,7 \%$ \\
\hline
\end{tabular}

Fonte: INE Indicadores Demográficos das Empresas não Financeiros em Portugal, 2008-2016

\footnotetext{
24 A autora partiu de uma análise extensiva da entrada e saída de empresas em Portugal, no período entre 2005 e 2012 . Dos resultados
} obtidos, conclui que as taxas de entrada são elevadas, enquanto as taxas de sobrevivência são baixas (Felix, 2017). 


\section{GRÁFICO 16. Sobrevivência de empresas com pelo menos uma pessoa remunerada}

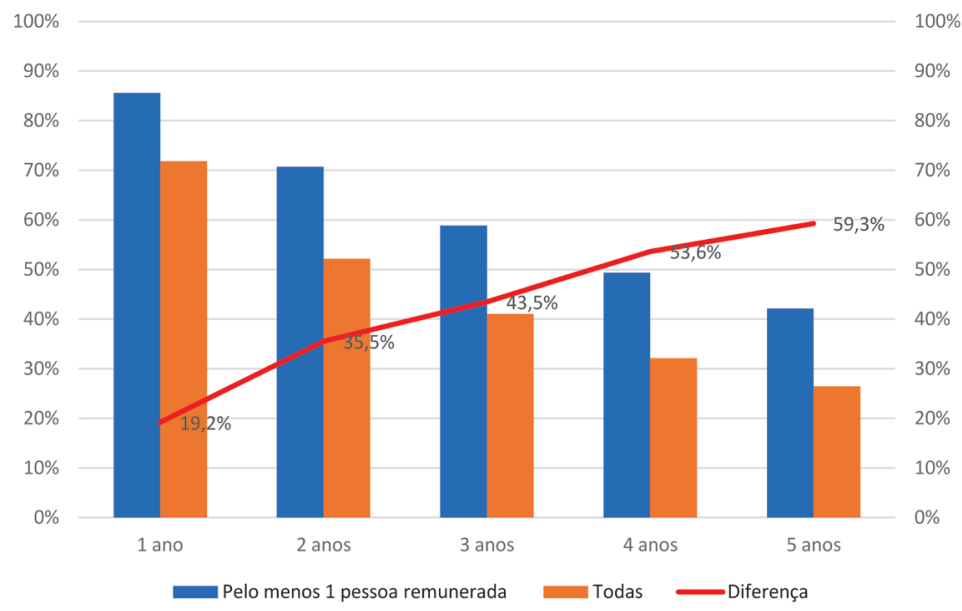

Recorrendo-se às médias das taxas de sobrevivência das empresas, no período de 1 a 5 anos desde o seu surgimento, e tendo presente se aquando do seu surgimento possuíam pelo menos uma pessoa remunerada, sobressai que:

as empresas do Norte possuem uma taxa de sobrevivência que, ao fim de 5 anos, é cerca de $13,7 \%$ superior à média nacional $(6,4 \%$ no caso das que possuíam pelo menos uma pessoa remunerada),

as empresas, que aquando do seu surgimento possuem pelo menos uma pessoa remunerada, possuem taxas de sobrevivência significativamente superiores (próximo dos $60 \%$ no final dos 5 primeiros anos).
Sabe-se que os primeiros anos de existências das empresas são os mais críticos no desenvolvimento do negócio, sua sustentabilidade e criação de emprego. Atendendo às especificidades das empresas de cariz familiar mapeadas da região Norte, é-nos possível registar valores expressivos de antiguidade das mesmas, considerando 20 anos e mais de existência: $32,2 \%$. É certo que $67,7 \%$ do total das empresas familiares têm apenas 20 anos, ainda que, entre 5 a 19 anos, o peso delas tenha uma expressão relativa significativa, representando quase $50 \%$ (Gráfico 17). Esta antiguidade das empresas familiares indicia que a maioria delas se encontra provavelmente na primeira geração do(a) fundado(a). 
GRÁFICO 17. EFs por antiguidade $(\mathrm{N}=41.375)$

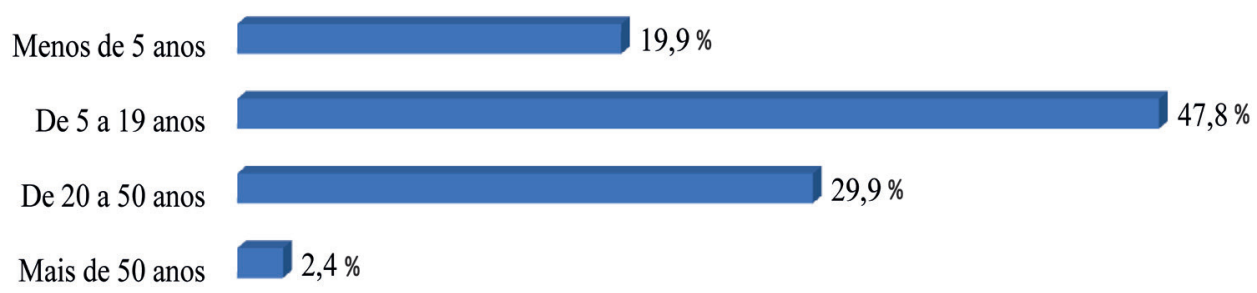

Fonte: BD Roadmapef

Ainda que se registe uma significativa heterogeneidade de novas empresas em função do setor de atividade económica, dimensão da empresa e conjuntura económica ${ }^{25}$, em especial com a crise internacional de 2008 e, em Portugal, com a ajuda financeira sob o Memorando da Troika (2011-2015), as empresas familiares apresentam uma maior resiliência e longevidade face ao cômputo geral das empresas.

Por sua vez, se consideramos os intervalos da dimensão das empresas familiares versus a sua antiguidade, de acordo com o Gráfico 18, o resultado mais notório consiste na correlação positiva observada entre empresas familiares mais recentes (até cinco anos) e a menor número de trabalhadores (considerando os intervalos de micro empresas usados neste estudo). Na verdade, a criação de novas empresas segue a tendência registada na literatura das organizações e do trabalho, ao se dar destaque à proliferação de empresas "magras" no contexto das novas configurações organizacionais.

Perante a flexibilidade e globalização de mercado e concorrência, o paradigma produtivo taylorista-fordista tende a ser substituído pelo modelo lean production (de inspiração japonesa), acompanhado por novos desenhos organizacionais assente no emagrecimento da empresa pela externalização/ outsourcing. Uma das consequências deste processo reside na destruição de postos de trabalho/ profissões e consequente aumento do desemprego estrutural (Marques, 2013, 2010). Como as empresas familiares de maior antiguidade são também aquelas que possuem um maior número de trabalhadores, a sua não sobrevivência refletirá um impacto muito significativo ao nível do emprego.

25 Tal como o comprova no seu estudo Felix (2017). 
GRÁFICO 18. EFs por dimensão e antiguidade

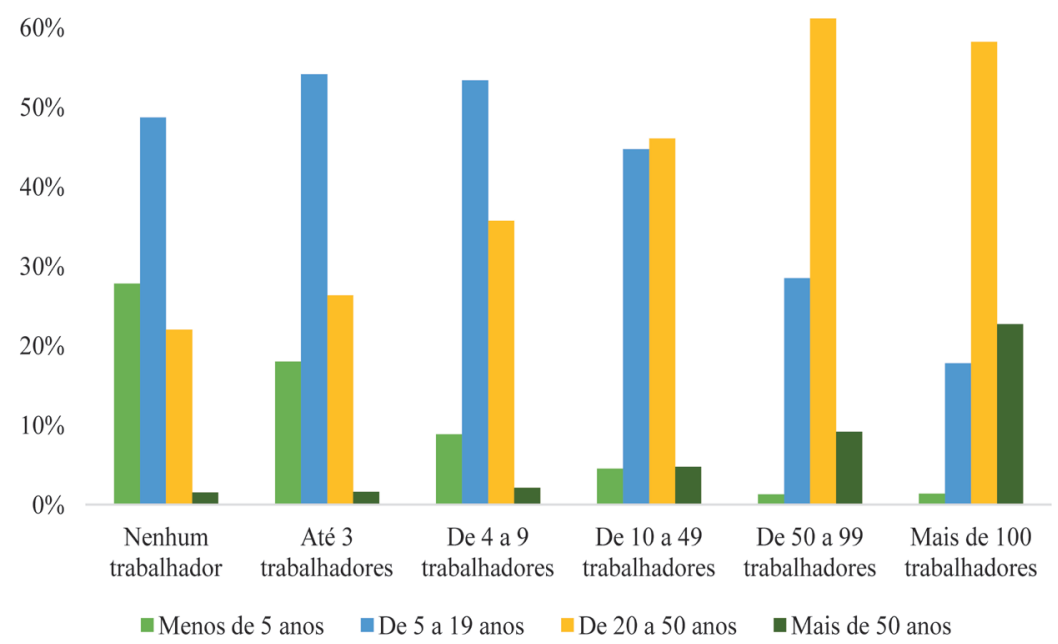

Fonte: BD Roadmapef.

A forma jurídica da empresa constitui um dos elementos formais indispensável ao ato de decisão de criação de um novo negócio empresarial, mas também de projeção quanto ao futuro desejável da mesma. Trata-se da identidade e do enquadramento legal aos quais a titularidade jurídica da empresa alicerça os seus compromissos e, no caso de uma empresa familiar, esses compromissos podem se estender também à família.

Assim, com base nos resultados obtidos do mapeamento, é possível registar a prevalência da sociedade por quotas como titularidade jurídica de quase a maioria das empresas familiares da região Norte, em linha com o que acontece para as empresas em geral (Gráfico 19). Aquela forma jurídica define o papel de cada um dos sócios em termos da sua responsabilidade limitada (Lda.), ou seja, os sócios são solidariamente responsáveis por todas as entradas convencionadas no contrato social, e só o património social responde pelas dívidas da sociedade. Já a sociedade anónima, que representa $7,3 \%$ das empresas familiares mapeadas, expressa maiores prescrições quanto ao número de sócios (à partida não inferior a cinco sócios) e o capital é dividido em ações, sendo que cada sócio limita a sua responsabilidade ao valor das ações que subscreveu.

GRÁFICO 19. EFs por natureza jurídica $(\mathrm{N}=41.451)$

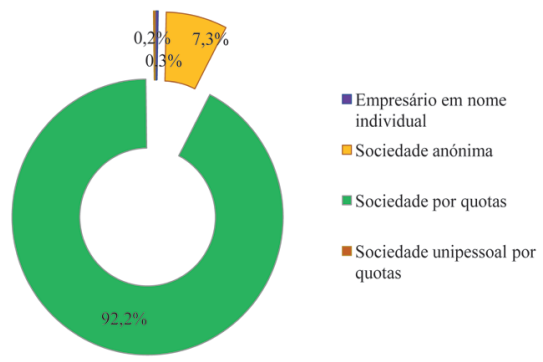

Fonte: BD Roadmapef. 
As outras formas jurídicas, nomeadamente empresário em nome individual e sociedade unipessoal por quotas são manifestamente residuais no conjunto das empresas que integram a Base de dados Roadmapef. Estas formas jurídicas reforçam a individualização da titularidade da empresa, porém há uma maior exposição ao risco económico na primeira situação face à segunda. Com efeito, ser empresário em nome individual não pressupõe a separação entre o património pessoal e o património afeto à atividade empresarial, pelo que este responde ilimitadamente perante os credores pelas dívidas contraídas no exercício da sua atividade. Deter uma sociedade unipessoal por quotas, pressupõe que a responsabilidade do sócio esteja limitada ao montante do capital social, respondendo apenas pelo património da sociedade.

\subsection{Em que atividades económicas as EFs são mais relevantes?}

As empresas familiares estão presentes em todos os setores de atividade, sendo nalguns deles líderes mundiais, o que revela que podem ser modernas e competitivas, mesmo com uma grande presença familiar na propriedade e/ ou gestão operacional.

Segundo o Banco de Portugal $(2018)^{26}$, a economia portuguesa tem revelado uma notável capacidade de ajustamento macroeconómico e uma reestruturação setorial assente numa dinâmica de internacionalização das empresas. Para este crescimento, refira-se a importância do turismo para o PIB e a retoma do setor da construção, em especial a partir de 2013.
Com base na descrição das secções de Classificação da Atividade Económica (CAE), as empresas familiares da região Norte encontram-se visivelmente espalhadas por diversos setores de atividade, ainda que, analisando o Gráfico 20, fique patente o peso relativo do comércio por grosso e a retalho (26,6\%); das indústrias transformadoras (17,3\%); e da construção (10\%).

Por sua vez, será importante não descurar os pesos relativos de empresas familiares nas atividades de consultoria, científica, técnicas e similares $(7,9 \%)$, nas atividades imobiliárias $(7,4 \%)$, nas atividades de saúde humana e apoio social (7,3\%), e no alojamento, restauração e similares (7,1\%). A agricultura, produção animal, caça, florestas e pesca (3,5\%) e transporte e armazenamento $(3,4 \%)$ tendem a estar também representadas, tal como outras atividades, ainda que os seus valores sejam mais residuais.

Ainda que a informação recolhida se encontre espartilhada pelas várias secções do CAE, é de destacar a dinâmica introduzida pelas várias atividades contíguas aos serviços, quer sejam em domínios relevantes do turismo por via do alojamento, restauração, comércio, transporte e imobiliária, entre outras, quer sejam em domínios relacionados com as TIC e atividades de consultoria científica e técnica, envolvendo mão-de-obra com perfis de qualificação tendencialmente de nível superior. Paralelamente, é de se assinalar a presença das empresas familiares no setor da indústria transformadora, remetendo para o papel central de geração de riqueza e criação de empresas, bem como no setor da construção que, como se sabe, constitui um setor económico com enorme poder de "alavancagem" de outras 26 Comunicado de maio 2018 (https://www.bportugal.pt/comunicado/comunicado-do-banco-de-portugal-sobre-o-boletim-economico-
de-maio-de-2018, Acesso a 24 de maio 2018). 
GRÁFICO 20. EFs por setores de atividade (CAE) $(\mathrm{N}=41.173)$

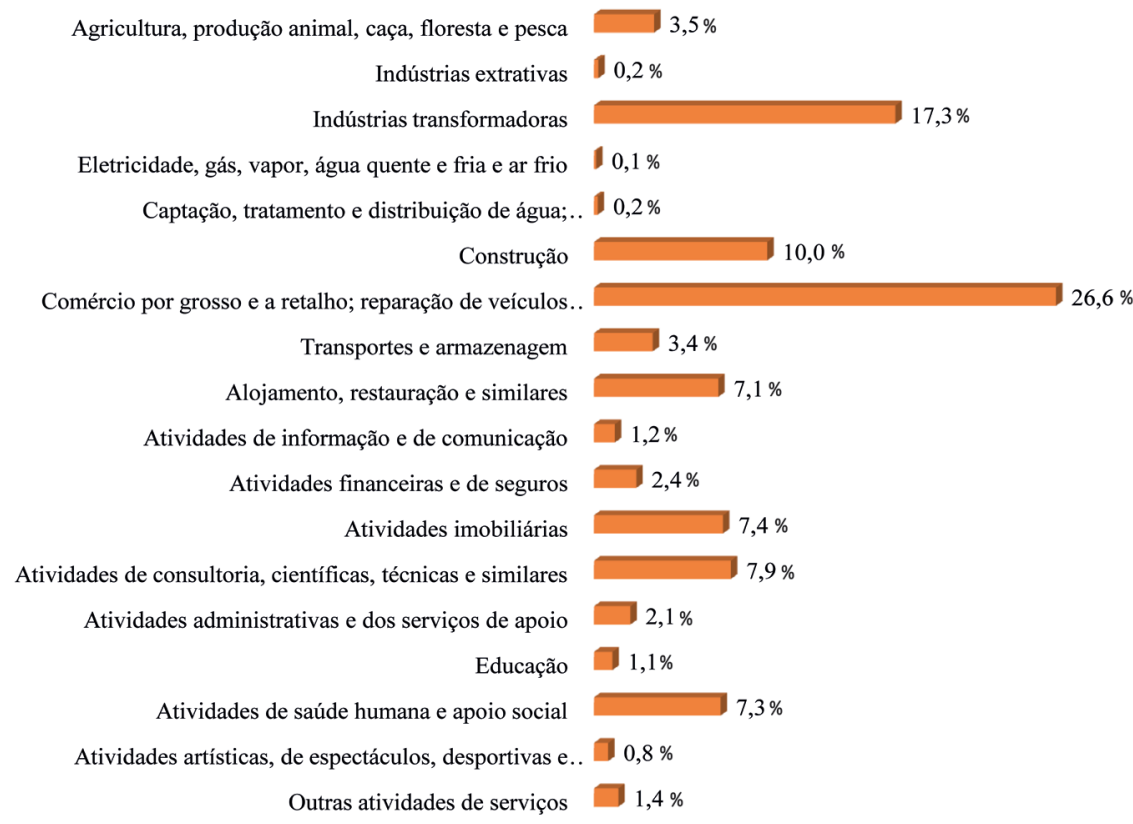

Fonte: BD Roadmapef.

atividades satélites. A distribuição das atividades económicas por NUTS III da região Norte espelha aquela tendência atrás descrita.

\subsection{Quanto faturam e qual o peso da exportação das EFs?}

O dinamismo da economia portuguesa depende também da capacidade de faturação das empresas e do potencial de internacionalização das mesmas, visível pelo crescimento das exportações.

Atrás referimos que a tipologia de PME predomina no contexto nacional e europeu, traduzido pelo número de trabalhadores. A este indicador importa agora associar o da faturação das empresas ${ }^{27}$ e a capacidade de liquidez financeira. Há evidência de que uma das principais

27 Para União Europeia, determinar se se é ou não uma PME implica considerar além dos indicadores da dimensão (trabalhadores, volume de negócios e balanço total) os recursos (por exemplo, pelo facto de ser detida por uma empresa de maiores dimensões, de ser associada ou parceira de uma empresa maior) (COM, 2015). Esta clarificação do entendimento de PME permite atender a eventuais distorções de mercado. 
preocupações ao nível da política europeia e nacional consiste em apoiar as PME no acesso ao financiamento, em especial no contexto da crise, com a disponibilização de fundos públicos e incentivos para ajudar à sua sustentabilidade.

Olhando para a realidade das empresas familiares do Norte, o volume de negócios declarado situa-se fundamentalmente nos intervalos inferiores a um milhão de euros, em especial, o que diz respeito a menos de $250.000 €(65,3 \%)$, reforçando o predomínio da presença esmagadora de micro e pequenas empresas (Gráfico 21).

Atendendo às especificidades das empresas familiares, a Comissão Europeia insta os seus Estados-membros a fornecerem ou a melhorarem as infraestruturas em termos de custos de produção, a fim de garantir a competitividade, a renovação, o crescimento e a sustentabilidade das empresas, em especial das micro empresas nos seus primeiros anos de vida. Mais, apesar de as empresas familiares terem geralmente um índice de património significativamente maior do que as empresas não familiares, no contexto da crise financeira recente, muitas das funções das empresas familiares encontram-se subfinanciadas, recomendando políticas de promoção a acesso fácil e aberto a fontes alternativas de financiamento, tais como cooperativas de crédito.

Da análise do Gráfico 22 e respetiva Figura 9, as empresas familiares do Norte apresentam maior volume de faturação à medida que se considera a sua idade em termos de longevidade. Com efeito, as empresas mais antigas, com idades superiores a mais de 50 anos tendem a apresentar volumes de negócio mais elevados, por oposição às empresas mais recentes. As que têm entre 20 a menos de 50 anos oscilam, ainda que representem uma proporção relativa muito significativa nos valores de faturação nos intervalos entre $10 \mathrm{M€e}$ $15 \mathrm{M} €$.

GRÁFICO 21. EFs por volume de negócios $(\mathrm{N}=35.780)$

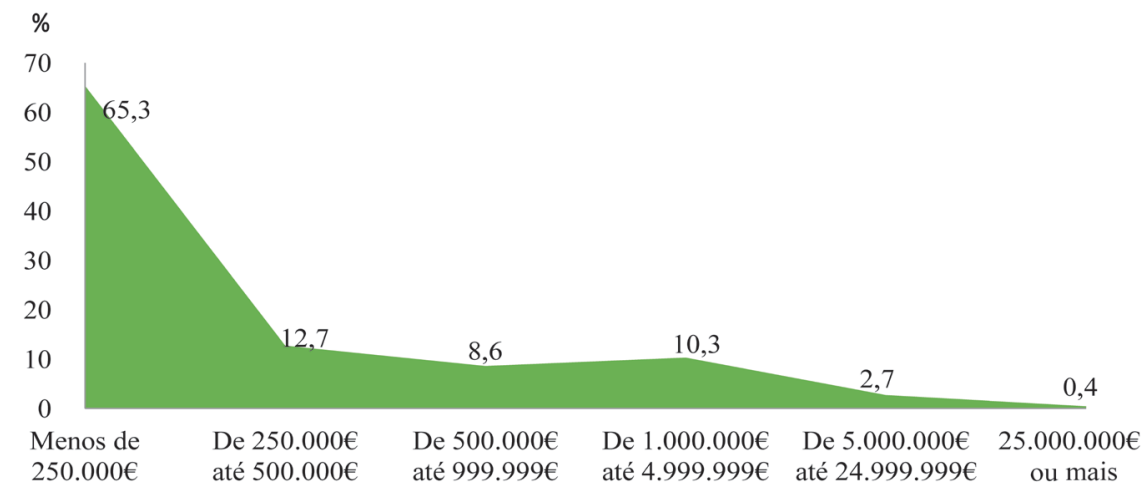

Fonte: BD Roadmapef. 
GRÁFICO 22. EFs por volume de negócios e antiguidade

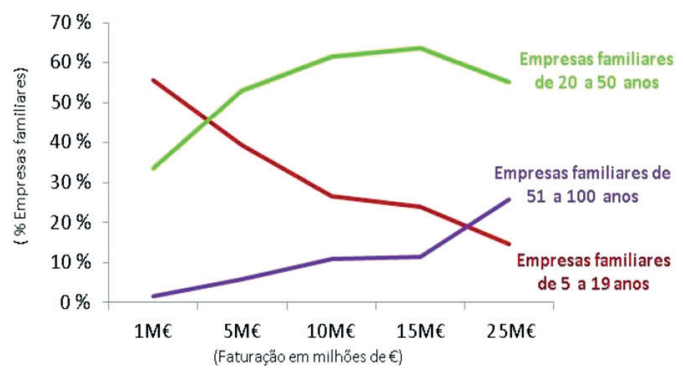

Fonte: BD Roadmapef.

FIGURA 9. EFs por volume de negócios e antiguidade

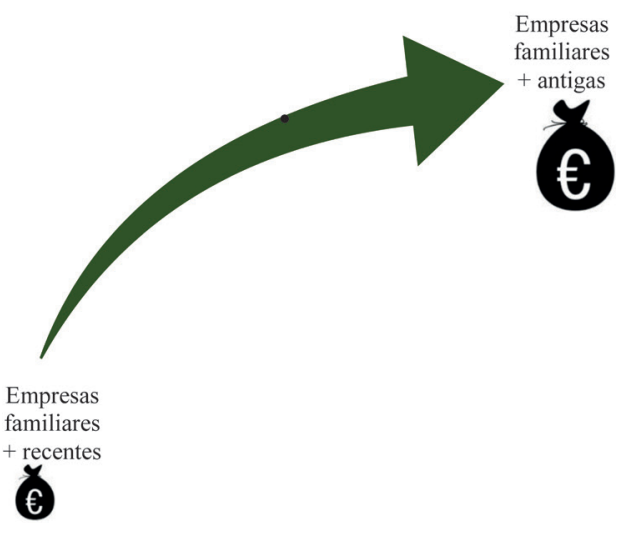

Reitera-se a evidência de que as empresas familiares mais antigas, ainda que sejam proporcionalmente em número inferior às empresas mais recentes, tendem a apresentar maior consolidação financeira, representando volumes de negócio superiores. Por sua vez, as empresas mais jovens assumem níveis mais reduzidos de faturação, o que pressupõe um maior esforço financeiro no equilíbrio interno ao nível das suas atividades principais e nas iniciativas de internacionalização e conquista de novos mercados.

Por isso, outra dimensão importante no crescimento e sustentabilidade de PME em geral reside na sua capacidade de internacionalização e competitividade face à concorrência no mercado global. Segundo o estudo mais recente do Observatório InSight (2018) ${ }^{28}$, internacionalizar significa quase exclusivamente exportar, ainda que haja algumas variações significativas entre empresas industriais, de produto e empresas prestadoras de serviços ${ }^{29}$. Das principais conclusões deste segundo inquérito aplicado a uma amostra de PME em 2017, refiram dois aspetos centrais: i) observa-se uma "realidade polarizada" se consideramos que para $25 \%$ das empresas, cujo core é a atividade internacional, esta representa mais de $80 \%$ do seu volume de negócio, ao passo que para cerca de $37 \%$ a atividade internacional se situa abaixo dos $30 \%$ do seu volume de negócios; ii) aposta na consolidação das condições para um crescimento sustentável em curso, em que $57 \%$ das empresas nacionais registaram um crescimento da sua atividade no exterior e 63\% preveem continuar a crescer em 2018.

Fica patente que a variável tempo é crucial para o processo de maturação da internacionalização e dos bons resultados daí decorrentes, mas também da implementação de condições adequadas, tais como, por exemplo: aumento da qualificação dos recursos humanos afetos à atividade

28 Plataforma de conhecimento com o objetivo de compreender a realidade de PME, analisando suas atividades de internacionalização e perspetivas de desenvolvimento futuro (Observatório Insight, 2018).

29 Facilitada por via de realização de feiras (e.g. promoção comercial, prospeção de mercado e angariação de clientes) e de plataformas digitais que permitem que os riscos financeiros sejam amenizados. 
internacional, por via do redimensionamento de equipas; otimização dos processos produtivos para manter a competitividade de produtos e serviços e aumento da capacidade produtiva instalada.

O desafio da internacionalização em mercados além-fronteiras assume uma relevância indiscutível no contexto das empresas familiares. Todavia, se atendermos ao seu comportamento no contexto da região Norte, $74,2 \%$ delas não registaram qualquer atividade de exportação, contra cerca de $26 \%$ que o fizeram. Para $15,7 \%$, o peso das exportações representa apenas $25 \%$ do total do seu volume de negócios; e só 4,7\% representam mais de $75 \%$ do total do volume de negócio (Gráfico 23).

Analisando apenas o contributo das empresas familiares em termos de exportação e cruzando com a antiguidade, é possível confirmar um perfil dicotómico em empresas com menos ou mais de cinco anos de existência (Gráfico 24): $41,1 \%$ exportam menos de $25 \%$ do volume de negócios enquanto 37,4\% exportam mais de $75 \%$.

GRÁFICO 23. EFs por peso das exportações $(\mathrm{N}=32.930)$

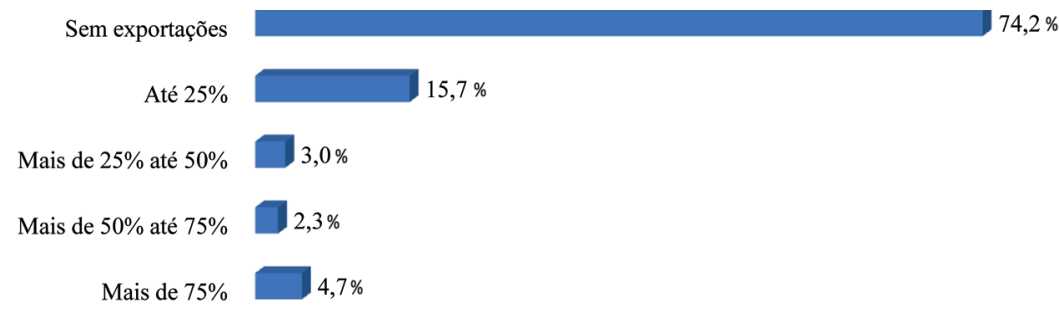

Fonte: BD Roadmapef.

GRÁFICO 24. EFs que exportam ( $N=8.492)$

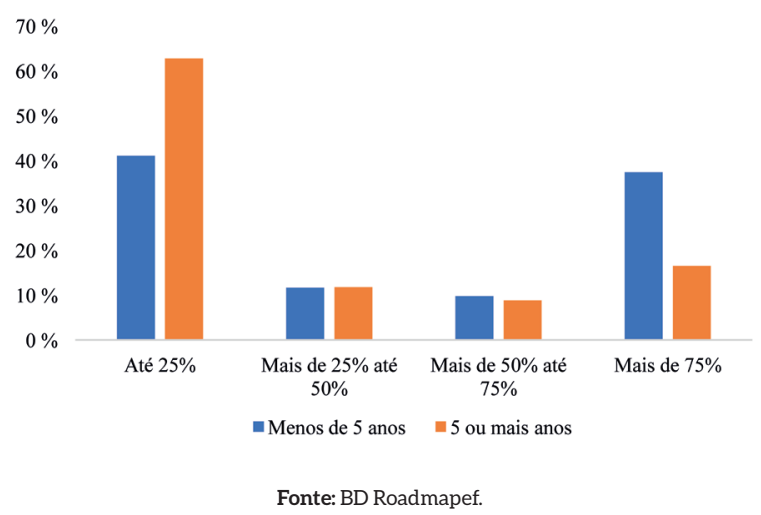


Estes resultados estão em linha com os obtidos no estudo supra referido sobre as PME em geral e analisando o comportamento das empresas mais recentes. No caso específico das empresas familiares, fica patente que um dos seus maiores desafios reside na implementação de políticas e estratégias que permitam ultrapassar a falta quer de experiência com a internacionalização, quer de conhecimento de oportunidades de captação de novos mercados.

\section{Retratos das EFs da região Norte}

No âmbito da ação de mapeamento das empresas familiares no projeto "Roadmap para Empresas Familiares Portuguesas" foi aplicado um questionário com o intuito de se recolher informação diversa, como, por exemplo, dimensão, antiguidade, internacionalização, inovação, recursos humanos e financeiros, planeamento estratégico e aspetos singulares diferenciadores deste tipo de empresas.

Apresentam-se de seguida os retratos de empresas familiares que responderam ao questionário (online e presencial). Ressalve-se, mais uma vez, que se trata de um estudo pioneiro em Portugal que conjuga propósitos de mapeamento, com produção de conhecimento sistematizado e aprofundado sobre esta tipologia empresarial.

\section{1. Breve apresentação das EFs participantes}

A amostra obtida pelas respostas das empresas familiares que participaram no questionário segue a distribuição pelas NUTS III da região Norte, antiguidade, forma jurídica e dimensão por número de trabalhadores (Tabela 5).
TABELA 5. Caraterísticas das EFs participantes

\begin{tabular}{|l|c|c|}
\hline NUTS III & $\mathbf{N} .^{\circ}$ & $\%$ \\
\hline Alto Minho & 67 & 5,8 \\
\hline Cávado & 189 & 16,5 \\
\hline Ave & 138 & 12,0 \\
\hline Área Metropolitana do Porto & 543 & 47,3 \\
\hline Alto Tâmega & 21 & 1,8 \\
\hline Tâmega e Sousa & 110 & 9,6 \\
\hline Douro & 53 & 4,6 \\
\hline Terras de Trás-os-Montes & 27 & 2,4 \\
\hline Total & $\mathbf{1 1 4 8}$ & \\
\hline
\end{tabular}

\begin{tabular}{|l|c|c|}
\hline Antiguidade & $\mathbf{N}^{\circ}$ & $\%$ \\
\hline Menos de 5 anos & 138 & 13,6 \\
\hline 5 a 19 anos & 410 & 40,4 \\
\hline 20 a 49 anos & 398 & 39,2 \\
\hline 50 a 100 anos & 67 & 6,5 \\
\hline Mais de 100 anos & 3 & 0,3 \\
\hline Toial & $\mathbf{1 0 2 2}$ & \\
\hline
\end{tabular}

\begin{tabular}{|l|c|c|}
\hline Forma jurídica & $\mathbf{N} .^{\circ}$ & $\%$ \\
\hline Sociedade por quotas & 815 & 71,0 \\
\hline Empresário em nome individual & 121 & 10,5 \\
\hline Sociedade anónima & 120 & 10,5 \\
\hline Sociedade unipessoal por quotas & 87 & 7,6 \\
\hline Outra & 5 & 0,4 \\
\hline Toid & $\mathbf{1 1 4 8}$ & \\
\hline
\end{tabular}

\begin{tabular}{|l|c|c|}
\hline $\begin{array}{l}\text { Dimensão por número de } \\
\text { trabalhadores }\end{array}$ & $\mathbf{N} .^{\circ}$ & $\%$ \\
\hline Até 3 trabalhadores & 326 & $28,4 \%$ \\
\hline 4 - 9 trabalhadores & 340 & $29,6 \%$ \\
\hline 10 - 49 trabalhadores & 327 & $28,5 \%$ \\
\hline 50 - 99 trabalhadores & 82 & $7,1 \%$ \\
\hline 100 e mais trabalhadores & 73 & $6,4 \%$ \\
\hline Total & $\mathbf{1 1 4 8}$ & \\
\hline
\end{tabular}

Fonte: Questionário EFs. 
As empresas familiares localizam-se sobretudo na Área Metropolitana do Porto, seguidas, com bastante diferencial percentual, nas sub-regiões do Cávado, do Ave e do Tâmega e Sousa. Importa registar que esta distribuição segue a tendência do mapeamento realizado para a região Norte (Gráfico 25).

\section{GRÁFICO 25. EFs participantes por NUTS III}

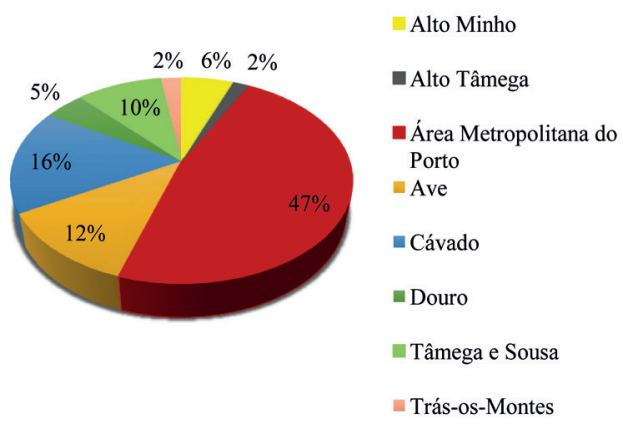

Fonte: Questionário EFs.

Para a teoria dos três círculos (Tagiuri \& Davis, 1982), as empresas familiares conhecem uma evolução no tempo, que passa do nascimento para a fase do crescimento da empresa e da família, até à sua implosão, da parte da empresa com alargamento de mercados, produtos/ serviços e uma estrutura de governação tendencialmente mais complexa, e da família, com o surgimento dos cônjuges e da 3. a geração, constituindo-se vários núcleos familiares. Atendendo aos resultados obtidos (Gráfico 26), mais de metade das empresas participantes têm até 20 anos de funcionamento, embora dos 20 aos 49 anos se registe uma percentagem muito significativa (41,3\%). Com mais de 50 anos, temos 6,7\% da amostra, incluindo apenas $0,3 \%$ para os que declararam ter mais de 100 anos. Ou seja, na nossa amostra destaca-se uma dicotomia entre as empresas mais jovens com menos de 20 anos, que se encontram na fase de crescimento da empresa e da família, e as com mais de 20 anos, remetendo para a consolidação e constituição de áreas de negócio tendencialmente mais complexos (incluindo a constituição de grupos de empresa) e multifamiliar ${ }^{30}$. As questões de profissionalização do negócio e expansão da atividade empresarial, por um lado, e a constituição de agregados familiares e seus descendentes, por outro, relacionam-se com os posicionamentos mais críticos face aos desafios destas empresas, como veremos mais à frente.

GRÁFICO 26. EFs participantes por antiguidade

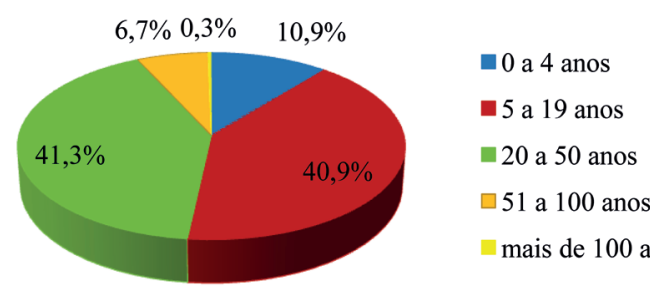

Fonte: Questionário EFs.

Na análise por dimensão da empresa familiar optou-se por manter a subdivisão de micro empresas até três trabalhadores e entre 4 a 9 trabalhadores para se captar a maior diversidade possível da realidade, em alinhamento com o racional seguido no mapeamento atrás realizado. Assim, tendo como referência o ano 2016, constata-se que predominam micro empresas, com $58 \%$, seguidas por pequenas empresas (entre

30 Esta questão é relevante no desenvolvimento da estrutura de governance quanto ao controlo dos negócios por uma família ou por várias famílias. Por limitações do questionário, não se abordou este tópico em específico. 
10 a 49 trabalhadores), com 29\% (Gráfico 27). As empresas com mais de 100 trabalhadores estão também representadas na amostra, sendo o seu peso relativo significativo (6\%), atendendo à percentagem inferior obtida no mapeamento para a região Norte.

\section{GRAFICO 27. EFs participantes por dimensão}

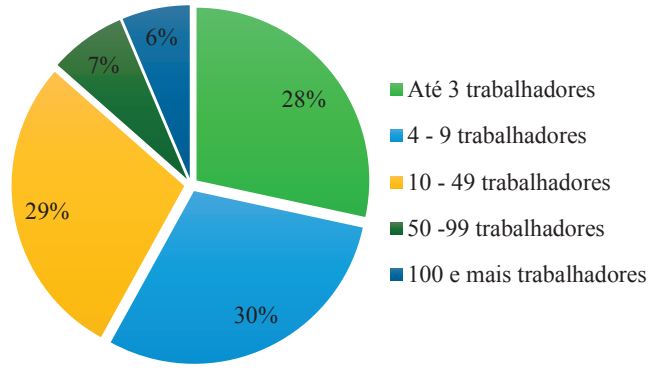

Fonte: Questionário EFs.

A forma jurídica mais presente na amostra é a da sociedade por quotas (71\%), seguida, com idêntica expressão percentual pelas sociedades anónimas e empresário em nome individual
(10,5\%) (Tabela 5). No cruzamento da dimensão da empresa pela forma jurídica, assinale-se o facto de as empresas de média e grande dimensão distribuírem-se por duas formas: $50,3 \%$ são sociedades por quotas e $49 \%$ são sociedades anónimas. Ainda assim, se atendermos à dimensão das empresas familiares, quase um terço delas $(29,9 \%)$ são empresas até três trabalhadores e assumidas por empresários em nome individual (Gráfico 28). Importa não esquecer que neste intervalo usado para definir a dimensão da empresa se incluem as que não possuem nenhum trabalhador, tal como se reportou atrás. Assumindo a figura de proprietário gerente (ainda que partilhando o capital social com o cônjuge), muitas vezes sem trabalhadores ao serviço, parece ser significativa a percentagem de sociedades que resultam de uma oportunidade de negócio ou necessidade de criar o próprio emprego. Veremos mais à frente que estas são as principais razões que estão na base da criação da empresa por parte do(a)s empresário(a)s respondentes, atuais fundadores da empresa e pertencentes à primeira geração.

GRÁFICO 28. EFs participantes por dimensão e forma jurídica

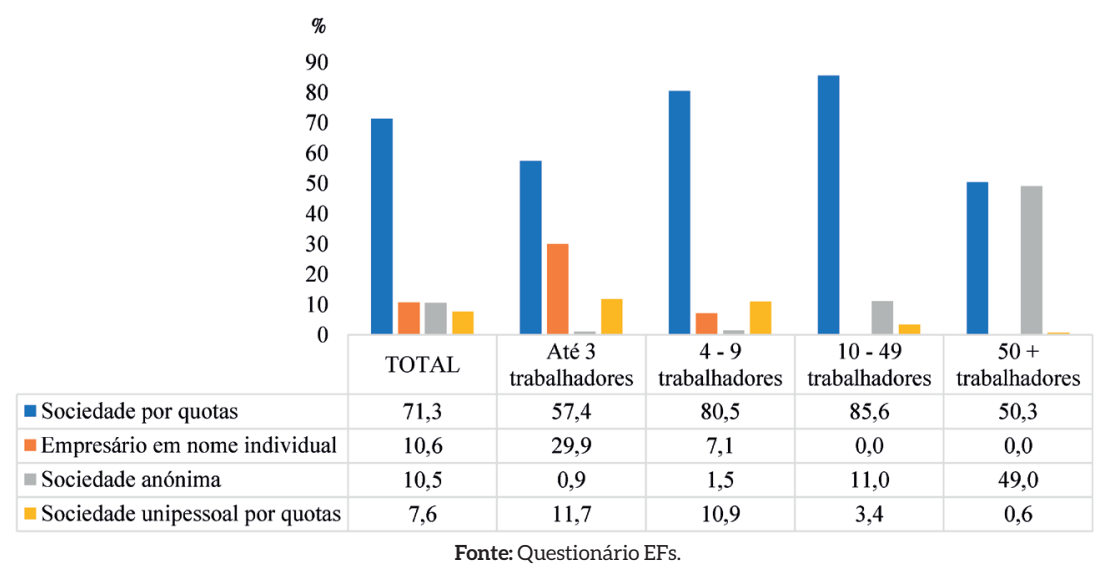


A atividade económica constitui outra das informações mais relevantes para a caraterização do perfil de especialização produtivo da região Norte. Antes de mais, importa registar a elevada percentagem em que não há qualquer tipo de informação sobre o CAE da empresa (46,9\%). Apesar de este "número" inscrever a atividade empresarial formalmente para efeitos de obrigações jurídico-legais, parece que tal não se apresenta como uma referência ou marcador "identitário" no quotidiano da vida empresarial. Aliás, não raras vezes, quando interpelado o(a) empresário(a) sobre o CAE em que o negócio se inscreve, a resposta tende a ser "não sei", "só confirmando", "o contabilista é que sabe", etc. $^{31}$. Todavia, quando se solicitou a descrição dos principais produtos ou serviços da empresa, quase todos responderam em conformidade ${ }^{32}$.

Os setores económicos de comércio por grosso e a retalho, indústria transformadora e atividades de consultoria científica, técnicas e similares assumem particular relevância, bem como os de alojamento e construção. Este retrato do padrão de especialização produtivo das empresas familiares encontra-se em linha com a informação mapeada para a região Norte (Gráfico 29). Ao se aprofundar a análise dos cinco setores de atividade com maior expressão na amostra, cruzando-os com a dimensão e antiguidade das empresas familiares (Gráficos 30 e 31), destacam-se os seguintes traços: i) há uma forte associação entre as indústrias transformadoras e as empresas de média e maior dimensão e as mais antigas no mercado; ii) o comércio por grosso e a retalho, incluindo a reparação de veículos automóveis e motociclos, prevalece quanto menor for a dimensão da empresa, ao passo que se regista um equilíbrio, com ligeiro acréscimo positivo, se se considerar sobretudo as empresas mais recentes; iii) quanto às atividades de consultoria científica e técnica, observa-se um maior impacto junto das empresas mais recentes e um relativo equilíbrio em empresas com menos de 20 anos, estando, igualmente, associadas a empresas com menor dimensão.

\section{GRÁFICO 29,}

\section{EFs participantes por CAE}

Fonte: Questionário EFs.

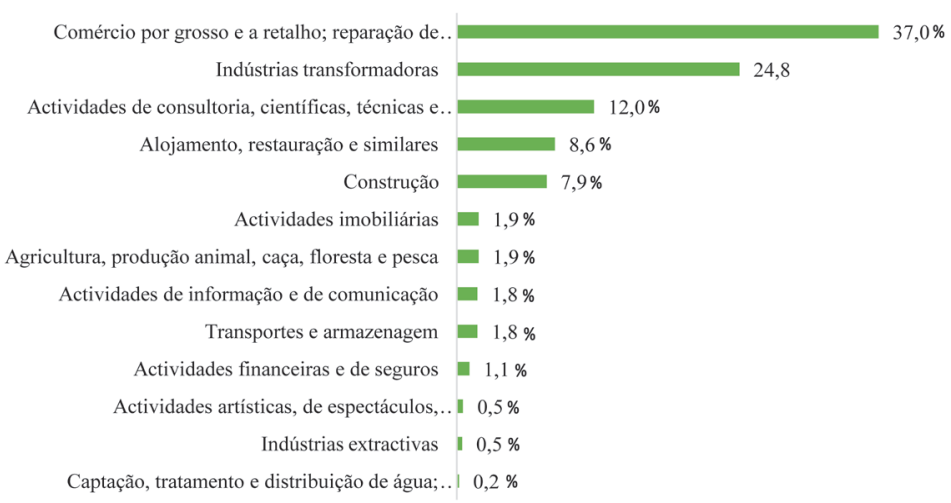

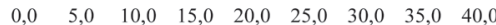

\footnotetext{
31 Respostas obtidas em contextos informais de interação em visitas realizadas às empresas familiares.

32 Tratando-se de uma pergunta aberta, a mesma exigiu que se procedesse a uma análise de conteúdo das respostas obtidas. Tal permitiu relacionar o CAE, ainda que não indicado, com a descrição dos principais produtos ou serviços. Este exercício encontra limites decorrentes da informação disponibilizada pelo respondente que, em certas circunstâncias, pode não se configurar totalmente compatível com o descritivo do CAE.
} 
GRÁFICO 30. Cinco atividades económicas mais expressivas por dimensão das EFs participantes (\%)

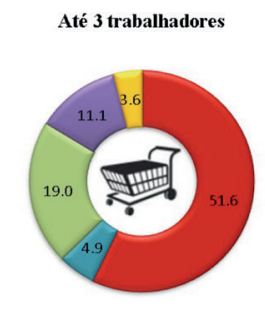

Indústria $\quad$ Construção

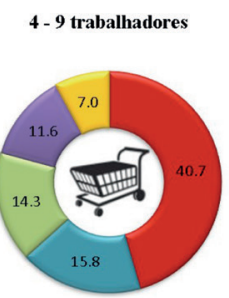

Alojamento e restauração
10 - 49 trabalhadores

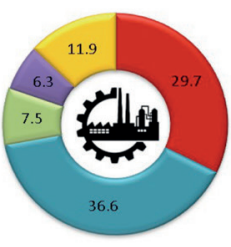

Comércio por grosso e a retalho
50 ou + trabalhadores

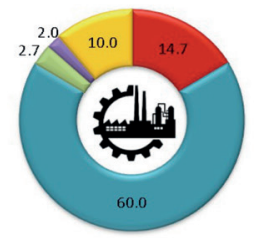

Actividades de consultoria, cientificas e técnicas

Fonte: Questionário EFs.

GRÁFICO 31. Cinco atividades económicas mais expressivas por antiguidade das EFs participantes (\%)

Menos de 5 anos

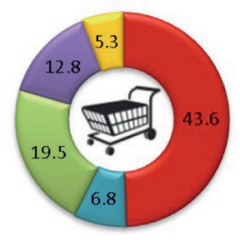

Indústria
$5-19$ anos

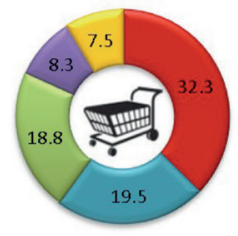

Alojamento e restauração
$20-49$ anos

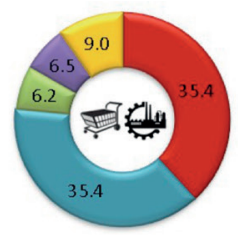

Comércio por grosso e a retalho
50 ou mais anos

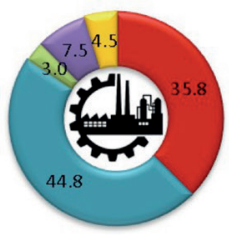

Actividades de consultoria, científicas e técnicas

Fonte: Questionário EFs.

Em síntese, quase metade das empresas familiares da amostra localiza-se na Área Metropolitana do Porto. São relativamente jovens, com menos de 20 anos de existência no mercado, ainda que quase um terço delas tenha entre 20 a 50 anos, pelo que é expectável que a figura do(a) atual fundador(a) se confunda com a de proprietário(a). São sobretudo micro e pequenas empresas, constituídas como sociedades por quotas, não obstante um terço delas assumir a figura de empresário em nome individual. A área de negócio focaliza-se, em especial, no comércio por grosso e a retalho, na indústria transformadora e nos serviços/ consultoria, incluindo o setor de turismo e informática. No setor da indústria transformadora as empresas familiares de maior dimensão e mais antigas são mais expressivas, ao passo que as mais recentes e tendencialmente mais pequenas se distribuem pelo leque setorial mais alargado de atividades económicas atrás referenciado. 


\subsection{Perfil do(a) empresário(a) familiar}

O perfil do(a) empresário(a) familiar da amostra é maioritariamente do sexo masculino, observando-se uma expressão mais significativa nas micro empresas entre 4 a 9 trabalhadores (72,9\%) e nas pequenas empresas $(68,2 \%)$ e um maior equilíbrio nas empresas até 3 trabalhadores e nas médias e grandes empresas (56,4\% e 60,0\%, respetivamente) (Gráfico 32).

Apesar do leque amplo de idades, os respondentes localizam-se nas faixas etárias dos 35 aos 49 anos (44,3\%), com 19,2\% com idades compreendidas entre os 20 e os 34 anos. A idade média global é de 45 anos, sendo 47 anos para os homens e 41 anos para as mulheres.

No que diz respeito às habilitações completas, $35,3 \%$ possuem licenciatura, enquanto $31,5 \%$ apresentam como habilitação mais elevada o ensino secundário e $20,8 \%$ o ensino básico. Com pós-graduação, ao nível do mestrado ou doutoramento, registam-se $9 \%$ dos participantes. Importa destacar, ainda assim, que as empresárias detêm maioritariamente habilitações de nível superior (licenciatura, mestrado e doutoramento), próximo dos $60 \%$, ao passo que mais de metade dos empresários (54,5\%) possuem habilitações equivalentes ao ensino básico e secundário. Nas empresas de menor dimensão, observa-se uma maior percentagem de respondentes com escolaridade mais elevada apenas ao nível do ensino secundário, enquanto nas empresas de maior dimensão se regista, proporcionalmente, uma maior percentagem de empresário(a) com maior escolaridade ao nível da licenciatura (51,0\% nas maiores empresas e 37,3\% na pequenas empresas) (Gráfico 33).

\section{GRÁFICO 32. Empresário(a)/ gestor(a) participante por sexo e dimensão}

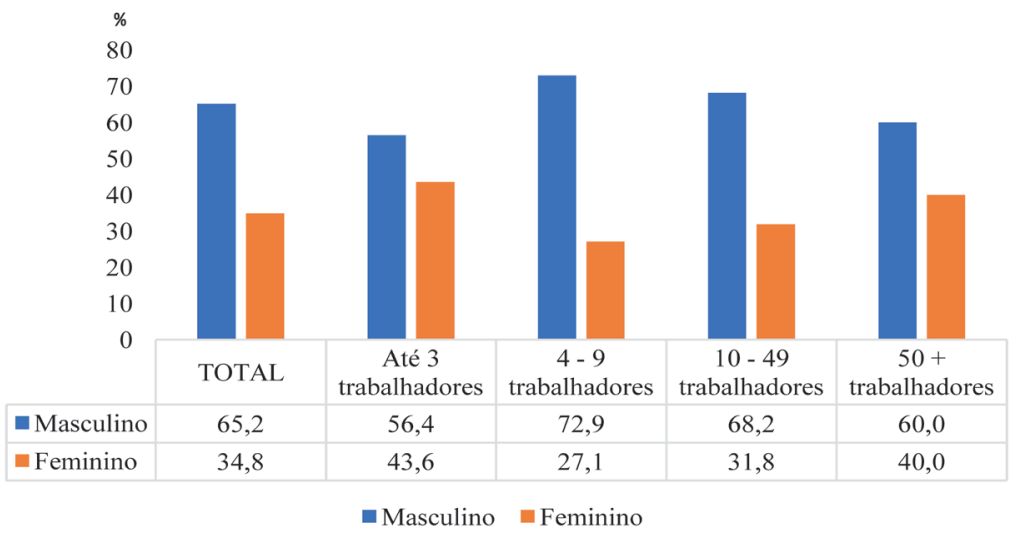

Fonte: Questionário EFs. 
GRÁFICO 33. Empresário(a)/gestor(a) participante por habilitações literárias completas e dimensão

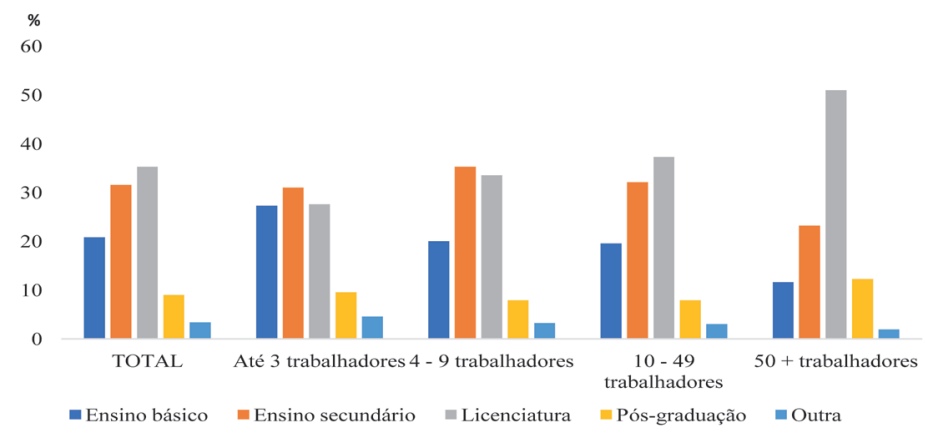

Fonte: Questionário EFs.

A progressiva qualificação dos portugueses tem vindo a se inscrever nos desígnios das políticas públicas nas últimas duas décadas, por via do cumprimento das metas da União Europeia. De forma consensual admite-se que Portugal registou uma profunda transição educativa, sobretudo nas gerações mais jovens. Com uma elevação do nível médio de qualificação geral, estas gerações de empresário(a)s testemunham o investimento recente em políticas educativas e iniciativas específicas de qualificação e reconhecimento de competências profissionais.

Ainda assim, segundo o estudo do Observatório das Desigualdades do ISCTE - Instituto Universitário de Lisboa, e da sua publicação mais recente (Cantante, 2018), mais de metade dos empregadores do setor privado $(54,6 \%)$ detém até o $9 .^{\circ}$ ano em termos de habilitações e 43,7\% da mão-de-obra empregada possuem apenas o ensino básico. Se consideramos o ensino secundário, há mais trabalhadores $(28,6 \%)$ do que empresários $(23,5 \%)$ que o detêm, sendo a diferença ainda maior quando nos reportamos ao ensino superior: $27,1 \%$ contra $20,1 \%$. Conclui o estudo sobre a já sinalizada persistência de défices estruturais ao nível da formação escolar dos portugueses, em especial da classe empresarial, o que explicará, por sua vez, a reprodução de um padrão de especialização produtivo assente em baixo valor em termos de inovação e diferenciação do produto/ serviço, condições indispensáveis para fazer frente à internacionalização da economia portuguesa.

Mais significativo parece ser o esforço persistente de qualificação da geração de empresário(a)s familiares, quando comparado com a média das qualificações em geral para os empresários ${ }^{33}$.Tal parece ser uma tendência que se verifica tanto nas empresas mais recentes e intermédias como nas mais antigas (Gráfico 34). É de realçar, igualmente, o perfil de qualificação de nível superior

\footnotetext{
33 Importava também perceber se o(a)s trabalhadores, bem como as empresárias/ gestoras das empresas familiares tendem a apresentar um nível de qualificação geral mais elevado quando comparadas com as empresas não familiares. Trata-se de uma temática relevante, dado que um dos desafios sinalizados pelo estudo do Grupo de Peritos da União Europeia (2009) reside na maior dificuldade em atraírem e reterem mão-de-obra (qualificada). Por limitações inerentes ao estudo, este tópico não foi desenvolvido, recomendando-se que o mesmo possa vir a ser alvo de atenção privilegiada em estudos posteriores.
} 
das jovens empresárias que terão certamente um papel de destaque na renovação do padrão de especialização produtivo, bem como na (expectável) transformação do estilo de liderança e gestão estratégica a médio e a longo prazo das empresas familiares.

As empresas mais antigas expressam um nível de qualificação mais alto, o que de certa forma reflete o reconhecimento e esforço que os empresários mais velhos colocam na formação dos seus descendentes: se as novas gerações estiverem mais bem preparadas, possuem maior capacidade para atuarem de forma profissional e, consequentemente, manterem ou elevarem a competitividade da empresa.

Com efeito, os nossos resultados, e, em especial, as entrevistas realizadas, parecem testemunhar o reforço das qualificações dos elementos da família empresária que terá reflexos, como veremos mais à frente, nos posicionamentos sobre a profissionalização da empresa familiar. Esta profissionalização não implica necessariamente a entrada de executivos externos à empresa, sobretudo membros não familiares, já que o(a)s atuais empresário(a)s declararam possuir as competências necessárias ao exercício das atividades em questão.

Quanto ao cargo ocupado na empresa familiar, as respostas recolhidas pelo questionário foram proporcionadas, na sua maioria, por gerentes ou administradores da empresa (77,2\%), sendo esta opção mais patente nas empresas de menor dimensão (nas empresas até 3 trabalhadores foram 87,1\%). Em contrapartida, nas empresas de média e maior dimensão as respostas foram dadas por $53,5 \%$ de gerentes ou administradores e por 36,8\% com funções diretivas (Gráfico 35), o que é de certa forma expectável dado o natural incremento do número de quadros diretivos e a sua representatividade relativamente aos gerentes ou administradores.

Em termos de antiguidade na empresa por parte

GRÁFICO 34. Empresário(a)/gestor(a) participante por habilitações literárias completas e antiguidade

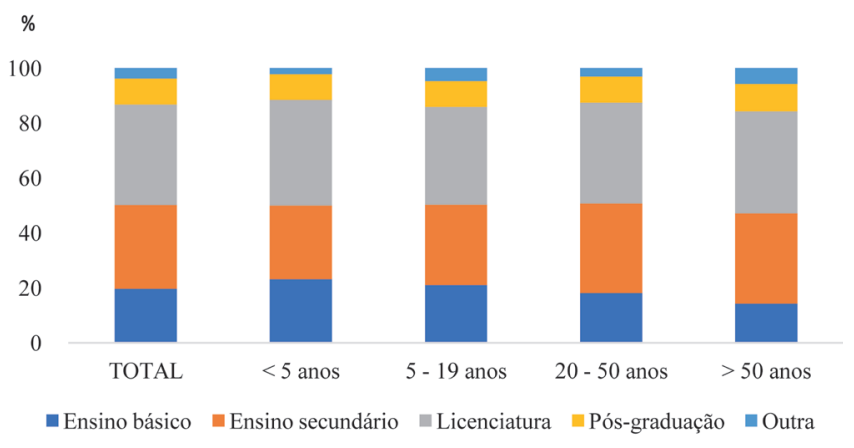

Fonte: Questionário EFs. 
GRÁFICO 35. Posição na empresa do(a) empresário(a)/gestor(a) participante por dimensão

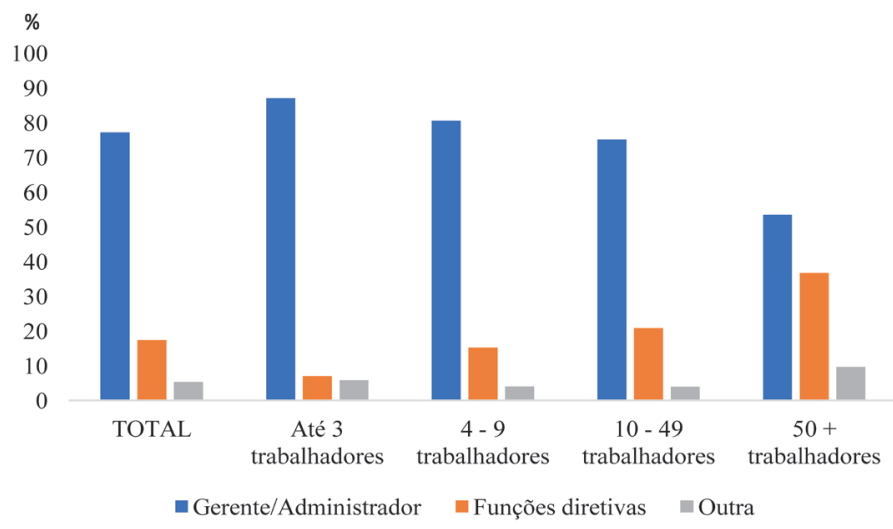

Fonte: Questionário EFs.

do(a) empresário(a)/ gestor(a), sem surpresa a proporção relativa mais elevada reporta-se aos que se encontram à frente dos destinos da mesma entre 10 a 24 anos (42,6\%), tal como os que declararam estar há mais de 25 anos $(20,8 \%)^{34}$. Não obstante, importa, igualmente, destacar os que se encontram há menos de cinco anos $(19,5 \%)$ e 5 a 10 anos (17\%), revelando uma tendência de "rejuvenescimento" pela entrada, em especial, das segundas gerações. Estas tendem a ser mais qualificadas do ponto de vista da formação superior adquirida, para além da experiência detida em atividades profissionais anteriores similares. Exploraremos este aspeto mais à frente.

Sabe-se que um dos problemas específicos das empresas familiares reside no facto de se congregarem, quase sempre na mesma pessoa - que é, regra geral o fundador -, os papéis de proprietário, gestor, trabalhador e familiar
(Costa, Rio \& Rio, 2011). Tal resulta da teoria dos "três círculos", que identifica a "família", o "negócio" e o "património", apresentada na década de oitenta por Tagiuri \& Davis (1982). No desenvolvimento mais recente desta teoria (Gersick, Davis, Hampton \& Lansberg, 1997) fica patente a diversidade de posicionamentos específicos naqueles três círculos, como os que resultam da interseção dos mesmos.

A partir da visualização da Figura 10, sinalizam-se 7 posições: (1) membros da família que não têm capital nem trabalham na empresa; (2) detentores de participações sociais que não são membros da família e não trabalham na empresa; (3) empregados que não são membros da família; (4) membros da família que têm participações no capital da empresa mas que não trabalham nela; (5) detentores de participações sociais que não são membros da família

34 Tal explica-se, em grande medida, pelo facto de o respondente ao questionário ser o fundador da empresa. 
mas que trabalham na empresa; (6) membros da família que trabalham na empresa mas não têm participações no capital da empresa; e (7) membros da família que têm participações no capital da empresa e trabalham nela. Por conseguinte, são várias as consequências decorrentes desta multiplicidade de posicionamentos, que correspondem também a diferentes expectativas e exigências, ao nível da estrutura de governação da empresa, liderança, planeamento estratégico e sucessão, entre outros fatores.

FIGURA 10. Teoria dos três círculos da EF

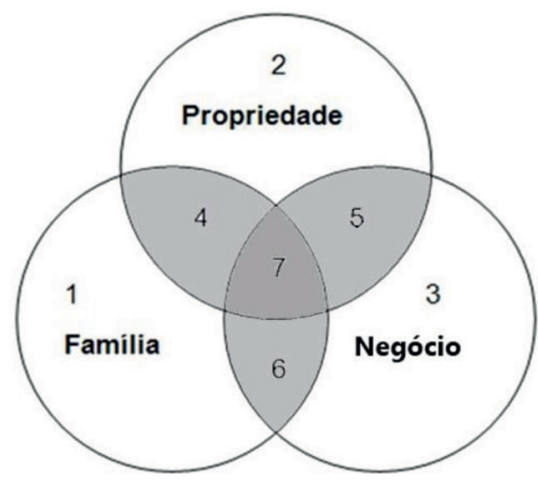

Fonte: Gersick, Davis, Hampton \& Lansberg (1997: 6).

Em síntese, o perfil do participante das empresas familiares aponta-nos para um empresário predominantemente masculino, com idade média localizada nos 47 anos, e habilitações literárias igual ou superior ao ensino secundário. As empresárias, por sua vez, possuem níveis de escolaridade superiores, quando comparados com os seus homólogos e têm uma idade média inferior (41 anos). Ambos tendem a ocupar maioritariamente posições de gerente/ proprietário, ainda que de forma mais expressiva para os homens do que as mulheres e encontram-se há mais tempo à frente da empresa (Figura 11).

\section{FIGURA 11. Perfil do(a) empresário(a) da EF}

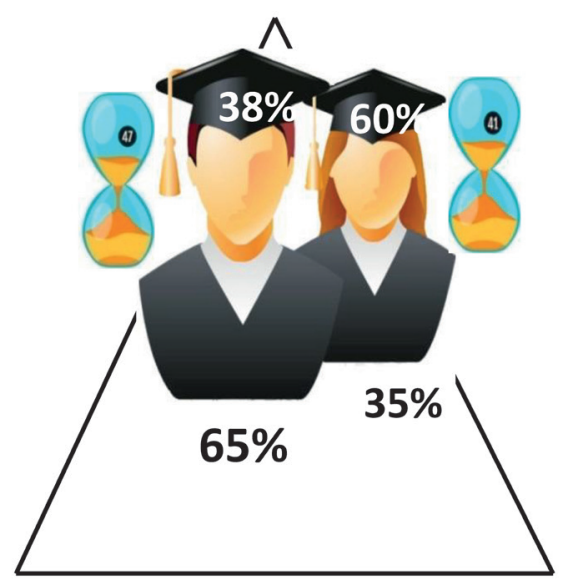

\subsection{Recursos financeiros $\mathbf{e}$ internacionalização}

Em Portugal, em linha com os demais países parceiros, as empresas familiares são um pilar da economia, contribuindo para a riqueza produzida em contexto nacional. Todavia, ao se analisar a atividade económica das empresas da amostra, estas tendem a indicar volumes de negócio relativamente limitados, o que terá consequências ao nível da sua capacidade de expansão em termos de financiamento e internacionalização.

Com efeito, verifica-se que 40,2\% de empresas familiares registaram, tendo como referência 31/12/2016, um volume total de negócios (vendas de produtos, vendas de mercadorias e prestações de serviços) inferior a 250 mil euros, embora $30,7 \%$ tenham ultrapassado um milhão 
de euros e 12,4\% tenham ultrapassado 5 milhões de euros (apenas 2,7\% ficaram acima dos 25 milhões). Na sua larga maioria (86,8\%), as micro empresas até 3 trabalhadores registaram um volume total de negócios inferior a 250 mil euros. Já no caso de empresas de 4 a 9 trabalhadores, 48,2\% não alcançaram os 250 mil euros, embora $31,2 \%$ registassem um volume de negócios entre 250 e 500 mil euros.

Por sua vez, o principal volume de negócios das pequenas empresas ficou entre um e 5 milhões de euros (42,8\%), com 11,9\% das empresas a ultrapassarem os 5 milhões de euros. Finalmente, nas médias e grandes empresas o principal registo no volume de negócios situou-se entre os 5 e os 25 milhões de euros (49\%), com 14,8\% destas empresas a ultrapassarem os 25 milhões de euros (Gráfico 36).

Em geral, a empresa familiar é tradicionalmente caraterizada por baixos níveis de propensão ao risco, optando por recorrer a capitais próprios e, assim, manter os seus níveis de endividamento de longo prazo reduzidos. Este tipo de comportamento também permite às empresas defenderem-se de uma possível perda de controlo da sua gestão/ liderança. Importa equacionar também o facto de muitas empresas familiares recorrerem a capitais próprios porque não conseguem aceder a outro tipo de formas de financiamento.

Os resultados revelam que o autofinanciamento $(59,8 \%)$ e o recurso à banca $(46,3 \%)$ são as principais fontes de financiamento das empresas familiares, embora 21,6\% tenham de recorrer a fundos familiares e $7,4 \%$ à venda de ativos. No caso de micro empresas, sobretudo até 3 trabalhadores, 66,9\% têm de recorrer ao autofinanciamento, enquanto as médias e grandes empresas e as pequenas empresas são aquelas que têm como principal fonte de financiamento o recurso à banca (71\% e 62,4\%, respetivamente). As

\section{GRÁFICO 36. Volume total de negócios das EFs por dimensão (31/12/2016)}

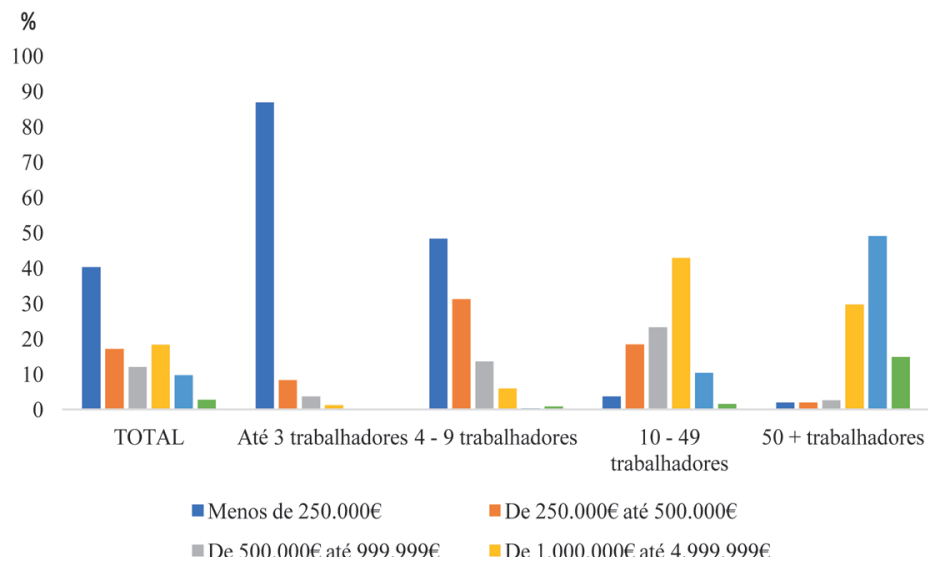

Fonte: Questionário EFs. 
empresas de maior dimensão recorrem menos a fundos familiares (7,1\%) (Gráfico 37). Regista-se, igualmente, uma tendência, ainda que não muito pronunciada, para que as empresas mais recentes recorram proporcionalmente mais ao autofinanciamento e a fundos familiares, ao passo que as empresas com mais anos de existência declaram recorrer mais à banca (Gráfico 38).

O recurso ao autofinanciamento pode ser

\section{GRÁFICO 37. Principais fontes de financiamento por dimensão}

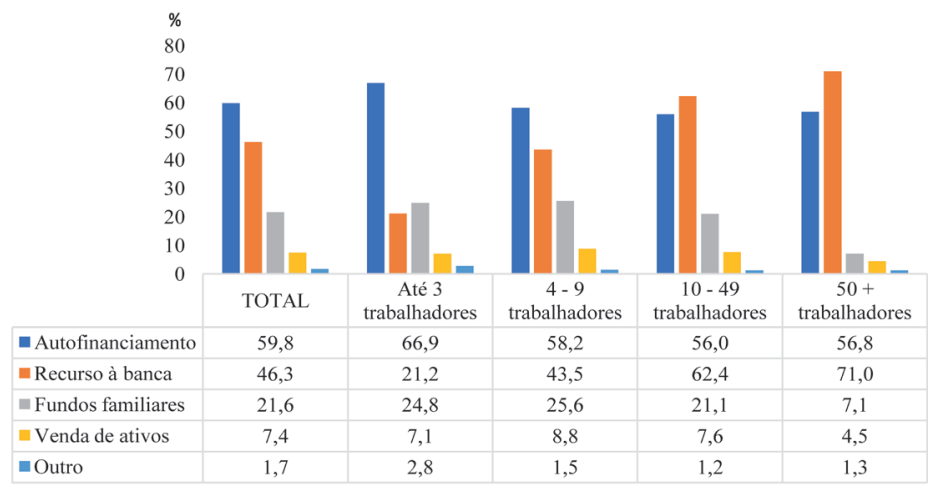

Fonte: Questionário EFs.

GRÁFICO 38. Principais fontes de financiamento por antiguidade

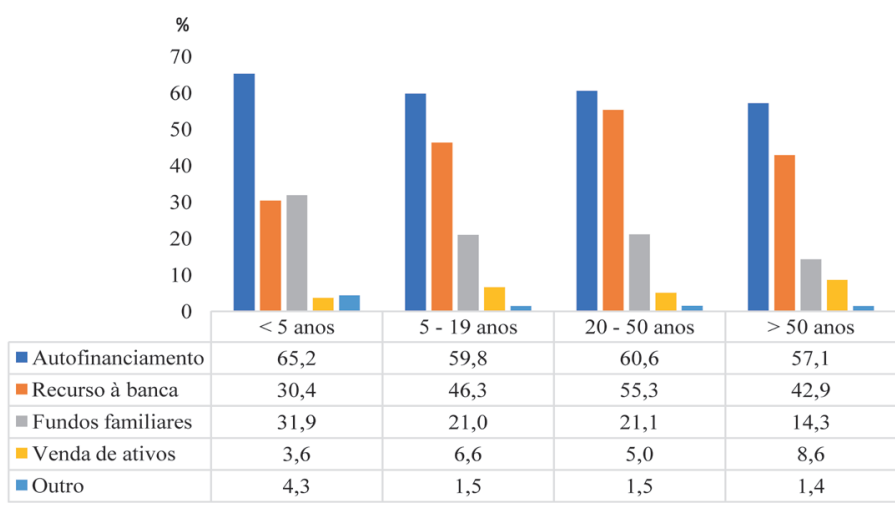

Fonte: Questionário EFs. 
limitativo para a empresa, reduzindo a sua capacidade de investir e crescer. Mas este problema torna-se ainda mais grave à medida que a empresa vai integrando mais gerações. Isto porque, por um lado, uma parte dos familiares pode desvincular-se da gestão da empresa, exigindo recompensas em forma de maiores dividendos e, por outro, existe um aumento progressivo dos membros da família a integrar a empresa. Daí resultar uma inevitável pressão sobre a liquidez da empresa familiar, o que reduz a capacidade da mesma se autofinanciar (Figura 12).

Fica patente que uma das especificidades das

FIGURA 12. Fontes de financiamento por dimensão de EFs

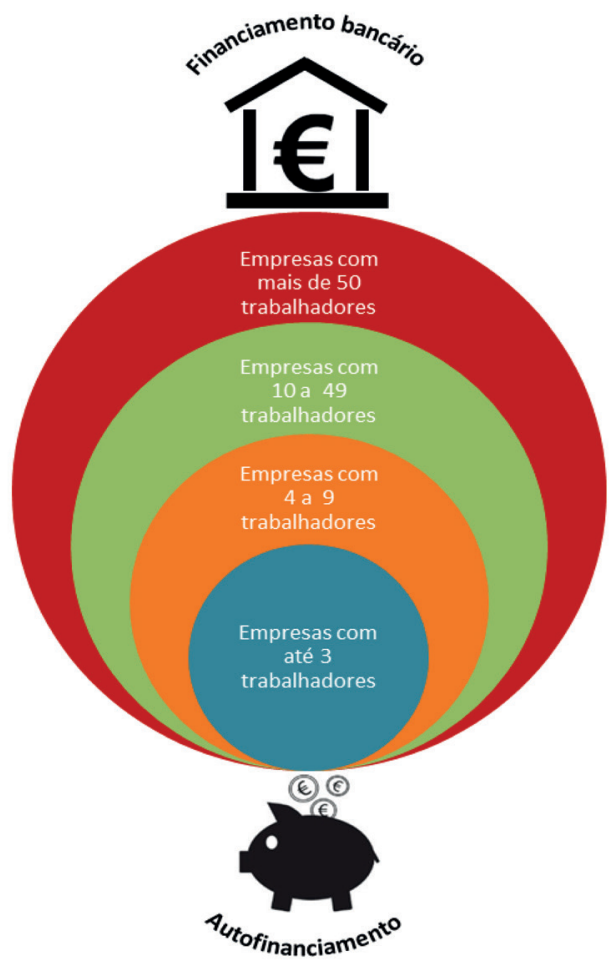

empresas familiares, em especial as de reduzida dimensão e nos primeiros anos de existência, reside na importância do recurso a fundos familiares para suportar/implementar um negócio ou esforço empreendedor que de outra forma podia não ser possível (muitas vezes funcionam como credores de último recurso).

Aproveitar capacidades, conhecimentos e experiências disponíveis no seio da família, transferindo-as para um projeto empreendedor, nomeadamente através de autofinanciamento ou fundos familiares, confere caraterísticas únicas e vantagens competitivas por parte das empresas familiares (Habbershon \& Pistrui, 2002; Habbershon \& Williams, 1999). Não obstante, se o papel da família pode ser crucial no esforço empreendedor e de crescimento das empresas, nem sempre a estratégia da gestão está alinhada com a da família, podendo esta criar obstáculos ao financiamento da empresa. Por exemplo, optar por estratégias de abertura do capital (via mercado de capitais) ou por celebrar outro tipo de parcerias estratégicas (por exemplo, joint ventures), para potenciar mudanças na empresa, podem não ser aceites pela família e/ou proprietário, limitando o acesso a essas formas de financiamento. Aliás, a literatura aponta para a resistência das empresas familiares, designadamente o seu comportamento introvertido, inflexível e pouco aberto em assumirem riscos associados ao empreendedorismo (Bettinelli, Fayolle \& Randerson, 2014; Hall, Melin \& Nordqvist, 2001).

Complementarmente aos recursos financeiros de que dispõem as empresas familiares, importa analisar o esforço de internacionalização por via de captação de novos mercados. Sabe-se que o processo de internacionalização se apresenta como um desafio difícil para as empresas familiares. Estas tendem a privilegiar uma atuação 
sobretudo a nível nacional (para mercados locais ou domésticos), embora nos anos mais recentes se tenha verificado um esforço significativo na sua internacionalização, sobretudo pela captação de novos mercados além-fronteiras. A literatura de suporte (Graves \& Thomas, 2008, 2004; Fernández \& Nieto, 2005; Gallo \& GarcíaPont, 1996) tem evidenciado, por um lado, a importância de as empresas familiares conquistarem novos mercados e gerarem produtos novos e diferenciadores para a sua sustentabilidade, e, por outro, as dificuldades que enfrentam, sobretudo, as de pequena dimensão. Estas resultam em especial dos recursos financeiros mais limitados, traduzidos em grande medida pelo volume de negócios e das fontes de financiamento disponíveis, como atrás se evidenciou, mas também pela menor preparação em termos de competências de gestão na internacionalização dos negócios.

A análise das respostas do questionário sobre o mercado principal dos produtos e serviços e peso das exportações, permite identificar um conjunto de traços que reforça o perfil de internacionalização das empresas familiares e as suas dificuldades principais, considerando a heterogeneidade interna por dimensão e antiguidade das mesmas.

Os produtos ou serviços das empresas familiares estão orientadas para todos os tipos de mercado, seja o mercado local/regional (35,4\%), seja apenas o mercado nacional (29,2\%), ou mercado nacional combinado com o internacional (35,5\%). Contudo, o tipo de mercado para o qual as empresas estão orientadas está, em larga medida, associado à dimensão da empresa. As empresas de maior dimensão estão orientadas simultaneamente para o mercado nacional e internacional (76,1\%), enquanto as empresas até 3 trabalhadores estão mais orientadas para o mercado local/regional (55,8\%). De referir, ainda, que a extensão ao mercado internacional se regista para $43,7 \%$ das pequenas empresas (Gráfico 39).

Cruzar esta informação com a antiguidade da

\section{GRÁFICO 39. Mercado principal por dimensão}

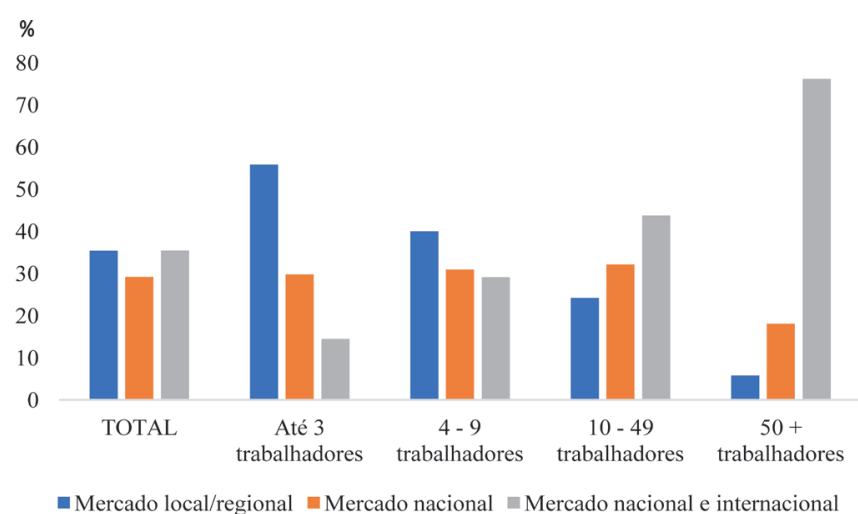

Fonte: Questionário EFs. 
empresa familiar revela que são sobretudo as empresas mais antigas (com mais de 20 anos e, em especial, com mais de 50 anos) que declararam exportar para mercados internacionais, incluindo o nacional. Confirma-se, assim, a importância de uma relativa consolidação do negócio para suportar o esfoço de internacionalização da atividade empresarial (Gráfico 40 e Figura 13).
Entre as empresas também orientadas para o mercado internacional, o peso das exportações no volume total de negócios ultrapassa os $75 \%$ em $24,6 \%$ das empresas, embora 42,3\% não ultrapassem os $25 \%$. Entre as empresas que não ultrapassam os $25 \%$ do peso de exportação, destaca-se as empresas familiares até 3 trabalhadores (59,6\%) e as que têm 4 a 9 trabalhadores (54,5\%). Em contrapartida, 15,3\% das

GRÁFICO 40. Mercado principal por antiguidade

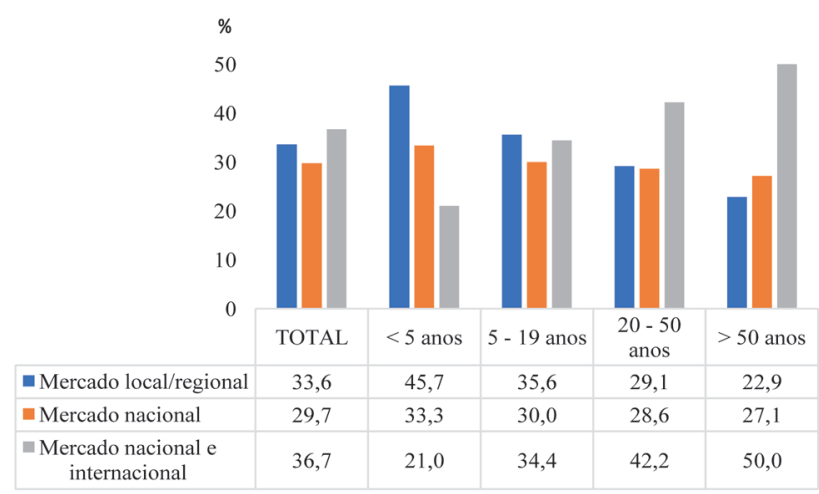

Fonte: Questionário EFs.

FIGURA 13. Internacionalização e dimensão das EFs.

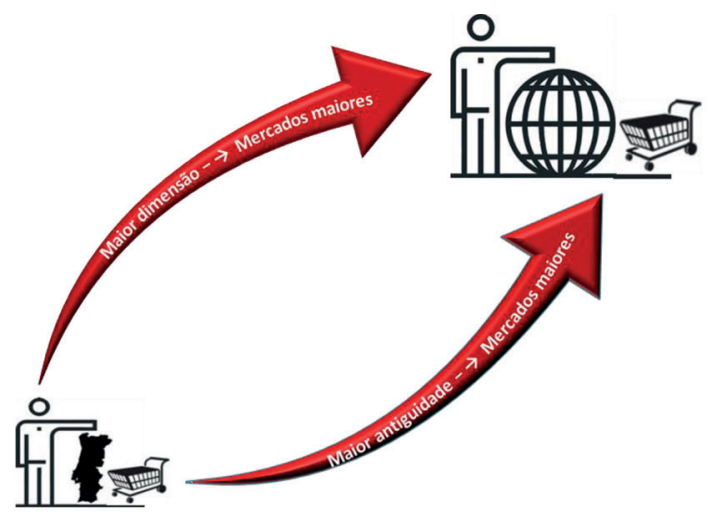


médias e grandes empresas têm exportações no volume total de negócios que ultrapassam os $75 \%$. (Gráfico 41 ).

Também a este nível, tal como referido atrás, são as empresas familiares mais recentes (com menos de cinco anos) que apresentam percentagem relativa mais significativa quanto ao peso de exportações ultrapassarem os $75 \%$ no volume total de negócios. Esta informação vai ao encontro do verificado aquando do nosso mapeamento das empresas familiares para a região Norte (Gráfico 42).

Os principais mercados de exportação são sobretudo os países dos Estados-membros da União Europeia, seguido de África, atestando as oportunidades proporcionadas pela integração de Portugal no Mercado Único e a proximidade

GRÁFICO 4 1 . Peso das exportações no volume total de negócios por dimensão

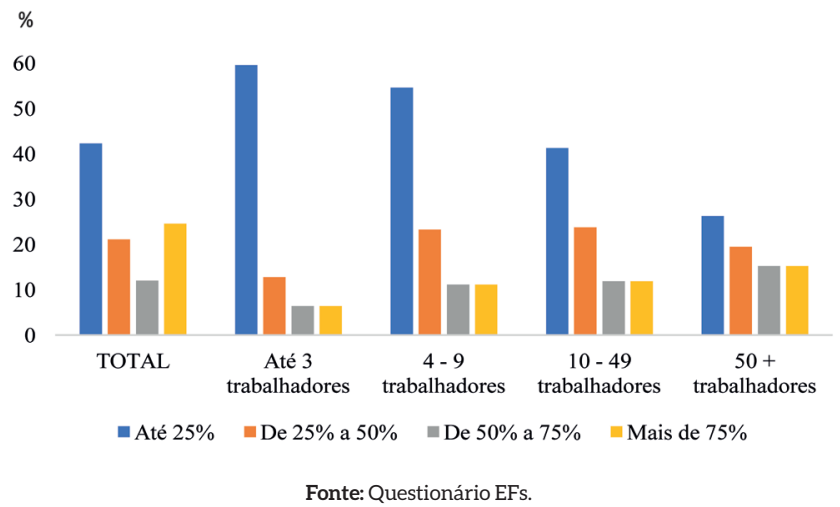

GRÁFICO 42. Peso das exportações no volume total de negócios por antiguidade

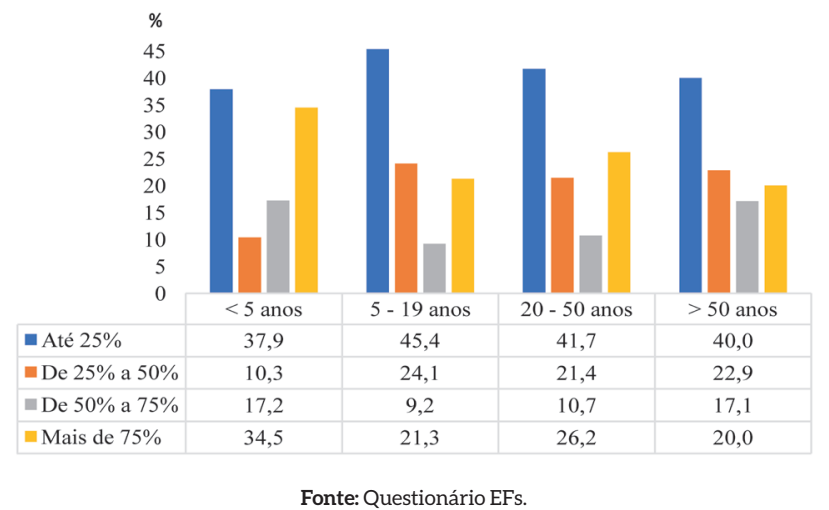


histórica e linguística com o continente africano, respetivamente (Gráfico 43).

Analisando a evolução ocorrida no volume efetivo das exportações no último ano (2016), verifica-se que em $50,4 \%$ das empresas foi positiva, tendo-se mantido nos mesmo níveis para 36,9\% das empresas e sido negativa em $12,8 \%$ das empresas (Gráfico 44). Esta informação é relevante se tivermos em conta o contexto recente de crise financeira e económica em Portugal, dando origem ao Memorando da Troika (2011- 2015).

Confirma-se, igualmente, que mais de metade das médias e grandes empresas registaram um aumento no volume de exportações no último ano, por contraponto com as pequenas empresas que assinalaram uma diminuição nas suas exportações. A antiguidade das empresas familiares não revela diferenciação significativa na evolução da atividade de exportação por consideração com o ano de 2016.
Em síntese, a capacidade de internacionalizar, em especial para as empresas familiares, sobretudo as de menor dimensão, pode ser limitada pela escassez de recursos financeiros, conhecimento sobre potenciais mercados e experiência com a internacionalização. Todavia, é pelo esforço de internacionalização que as empresas familiares poderão melhor se posicionar no mercado global, com alargamento dos seus mercados além-fronteiras, aumentando o seu volume de negócios.

Perante esta dificuldade, importa que a Comissão Europeia e os Estados-membros promovam medidas de apoio, designadamente na disponibilização de infraestruturas eficientes em termos de custos e disseminação de informação no portal de Internacionalização de PME. Esta é uma dimensão de crucial importância para garantir competitividade, renovação, crescimento e sustentabilidade das empresas, com particular atenção para micro e pequenas empresas e nos seus primeiros anos da sua vida empresarial.

GRÁFICO 43. Mercados principais de exportação $(\mathbf{N}=407)$

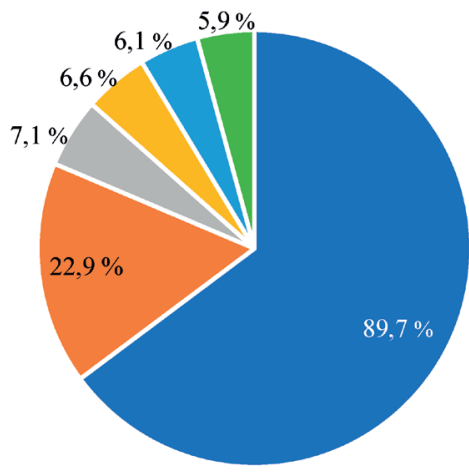

União Europeia $=$ África $"$ Ásia $=$ América Latina $=$ América do Norte " Outro

Fonte: Questionário EFs. 


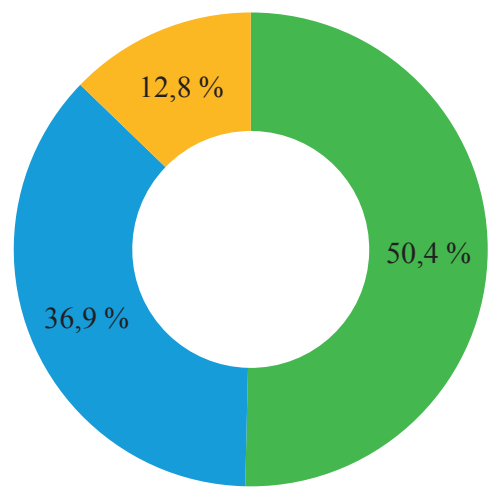

Aumentou Manteve-se idêntico Diminuiu

Fonte: Questionário EFs.

\subsection{Inovação, qualidade e preservação ambiental}

A inovação constitui-se num fator determinante do sucesso a longo prazo para qualquer tipo de empresa. Não é consensual que as empresas familiares dinamizem mais a inovação do que as não familiares. Há estudos (Chrisman et al., 2010; Chrisman, Sharma \& Taggar, 2007; Naldi et al., 2007; Sharma \& Manikutty, 2005) que defendem que as empresas familiares tendem a ser mais conservadoras e avessas ao risco, assumindo um comportamento estratégico de resistência à mudança. Estas preferem utilizar recursos internos em detrimento de processos de colaboração externa e, consequentemente, tendem a ser apresentadas como tradicionais e resistentes à mudança. Em concreto para alguns autores, como Munari, Oriani \& Sobrero (2010) e Block (2012), ser empresa familiar influencia negativamente a propensão para a inovação.
Todavia, em sentido contrário, outros autores (Kim et al., 2008; Llach \& Nordqvist, 2010) projetam um impacto positivo das estruturas familiares na inovação. As caraterísticas diferenciadoras destas empresas, tais como a lealdade e a confiança, permitem sustentar relacionamentos de longo prazo e o acesso privilegiado a uma rede de parceiros que apoiam o processo de inovação. Essa é uma das linhas de argumentação de Werner, Schröder \& Chlosta (2018) ao sugerirem que a perspetiva de longo prazo das empresas familiares afeta positivamente a inovação, pela capacidade de preservação de conhecimento e competências da força de trabalho ao longo das flutuações conjunturais.

Com efeito, a este respeito e numa perspetiva internacional, segundo o European Family Business Barometer (KPMG, 2016: 15), as empresas que possuem planos estratégicos e que preveem efetuar investimentos financeiros nos próximos 
anos, referem que os mesmos serão direcionados para o negócio principal (78\%), inovação e tecnologia (58\%), pessoas, recrutamento e formação (47\%) e internacionalização (40\%). Assim, sendo a inovação um fator importante da gestão estratégica ao contribuir para o sucesso da empresa, torna-se essencial compreender melhor como estas empresas inovam e saber se estão, ou não, próximas de entidades, como, por exemplo, associações empresariais, universidades e centros de I\&D. Ao se analisar a inovação nas empresas importa ter em conta as caraterísticas estruturais da empresa, tais como dimensão e tipo de atividade, mas também os recursos que empregam em termos de I\&D, e as alianças que promovem com centros de investigação e universidades para apoiar nesse processo.
Antes de mais, da nossa amostra, apenas 11,2\% delas declaram possuir um departamento/núcleo de investigação e desenvolvimento (I\&D) e essa existência está diretamente relacionada com a dimensão da empresa: $34,8 \%$ das empresas de maior dimensão têm departamento/núcleo de I\&D, contra apenas $13,8 \%$ em pequenas empresas e 9\% em micro empresas (Gráfico 45 e Figura 14).

Em consonância com esta débil relação com a inovação por dimensão, compreende-se que sejam as empresas mais consolidadas no mercado com mais anos de existência que refiram possuir um departamento/ núcleo de I\&D na estrutura da sua organização. Em todo o caso, são valores manifestamente residuais considerando a nossa amostra.

\section{GRÁFICO 45. Departamento/núcleo de I\&D por dimensão da EF}

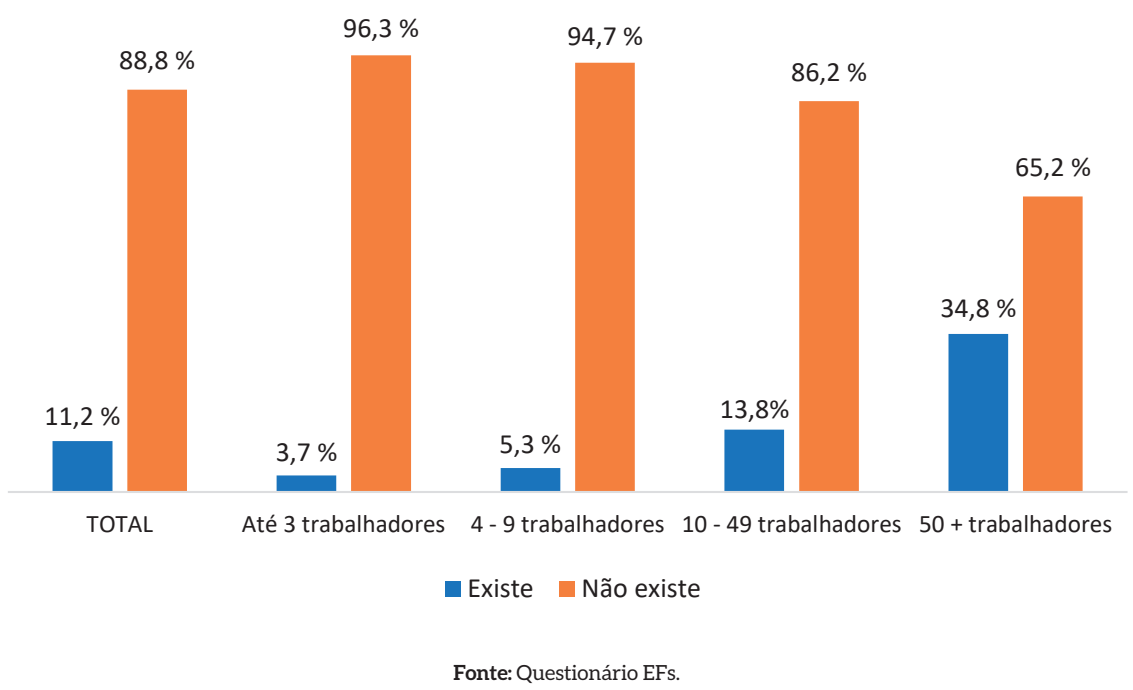


Por conseguinte, quando interpeladas sobre se estiveram envolvidas num processo de inovação nos últimos três anos, as respostas obtidas reiteram uma posição mais conservadora alicerçada numa aversão ao risco, como atrás referido. Apenas 16,3\% responderam afirmativamente e, também neste caso, destacam-se as médias e grandes empresas (34,2\%), seguindo-se as pequenas empresas (19,3\%) (Gráfico 46). O mesmo se passa considerando a antiguidade das empresas familiares: as com mais de 50 anos declararam estarem relativamente mais envolvidas em processos de inovação quando comparadas com as mais recentes.

FIGURA 14. Departamento I\&D e inovação por dimensão das EFs

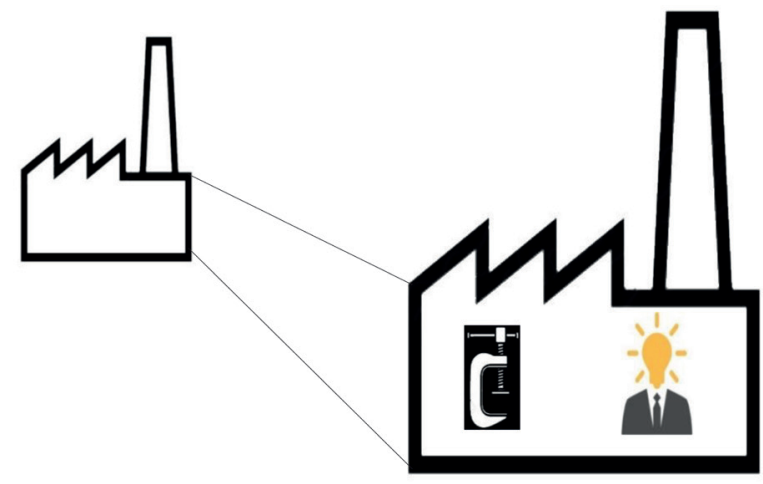

GRÁFICO 46. Envolvimento num processo de inovação, nos últimos 3 anos

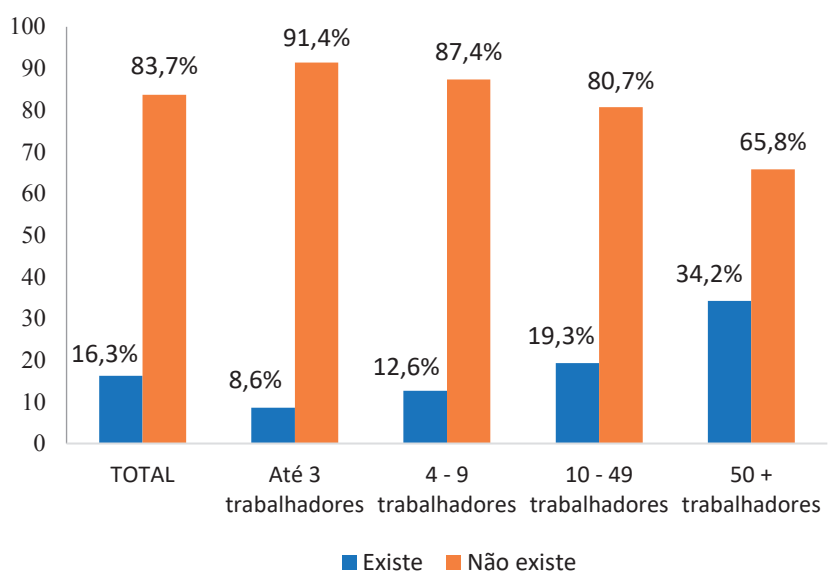

Fonte: Questionário EFs. 
A relevância da inovação nas sociedades familiares aparece refletida no estudo Next generation family businesses (Deloitte University EMEA CVBA, 2017), realizado junto de empresas familiares sedeadas na região EMEA (Europe, Meadle East and Africa), onde mais de $80 \%$ dos participantes referem que a cultura das suas empresas encoraja a inovação e a geração de novas ideias e cerca de $86 \%$ consideram a inovação uma oportunidade e uma parte importante dos seus planos estratégicos.

Por sua vez, o resultado do esforço de inovação pode refletir-se em melhorias processuais e ganhos de eficiência na cadeia de criação de valor e, em termos de resultados da inovação, através, por exemplo, da introdução de novos produtos e desenvolvimentos na propriedade intelectual (por exemplo, patentes e copyrights).

Entre as empresas que lançaram ou estiveram envolvidas num processo de inovação nos últimos 3 anos, apenas $22,5 \%$ procederam ao registo de propriedade intelectual, destacando-se mais uma vez as médias e grandes empresas, seguidas das pequenas ( $28,3 \%$ e $27 \%$, respetivamente) (Gráfico 47).

GRÁFICO 47. Registo de propriedade intelectual por dimensão

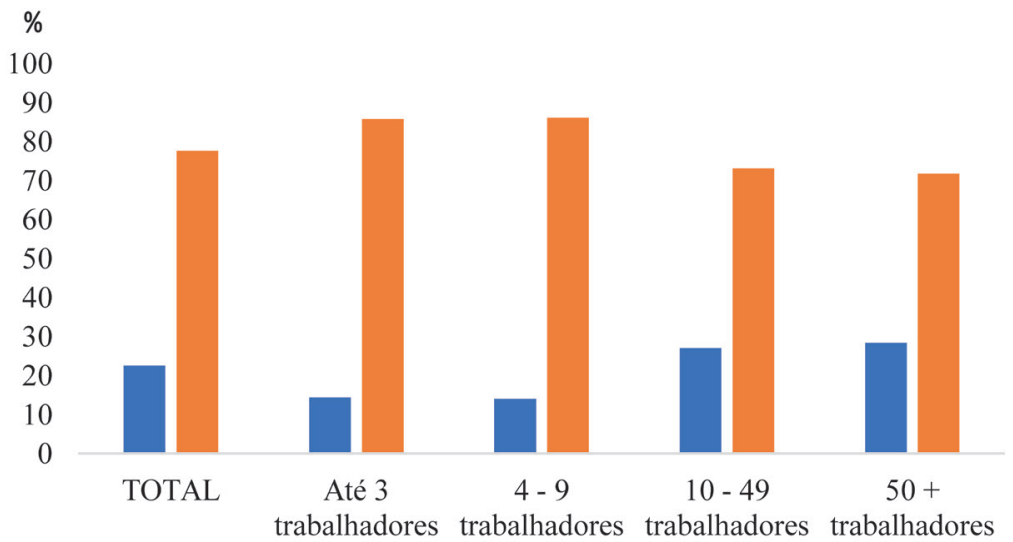

Fonte: Questionário EFs. 
A propriedade intelectual traduziu-se, fundamentalmente, em patentes $(54,8 \%)$, mas também em desenhos ou modelos (16,7\%), em direitos de autor (14,3\%), em modelos de utilidade (7,1\%) e outro tipo de registos (26,2\%). A análise por dimensão da empresa revela, curiosamente, que as micro empresas, com menos cinco anos, apostam quase de forma exclusiva nas patentes e com particular expressão em termos relativos, quando comparadas com as empresas de maior dimensão. Estas últimas tendem a diversificar as modalidades do registo da propriedade intelectual (Gráficos 48 e 49).

\section{GRÁFICO 48. Em que se traduziu a propriedade intelectual por dimensão?}

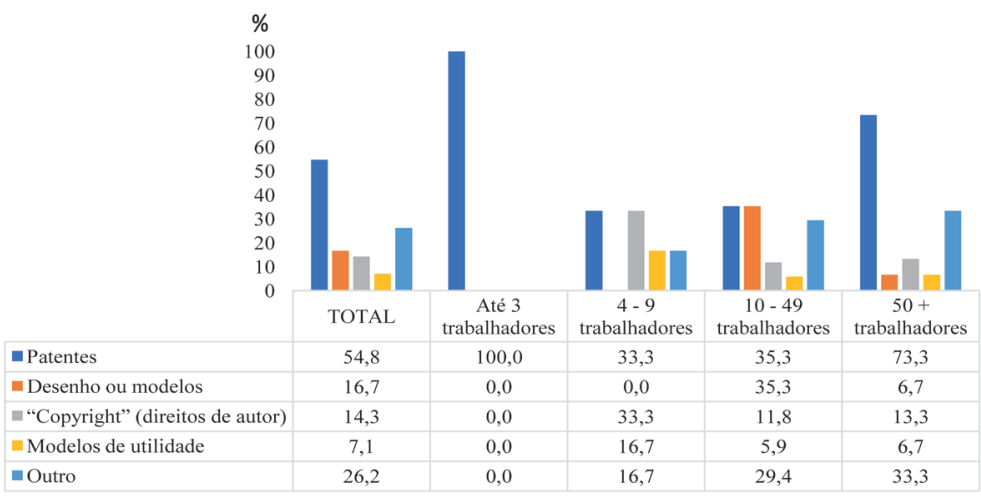

Fonte: Questionário EFs.

GRÁFICO 49. Em que se traduziu a propriedade intelectual por antiguidade?

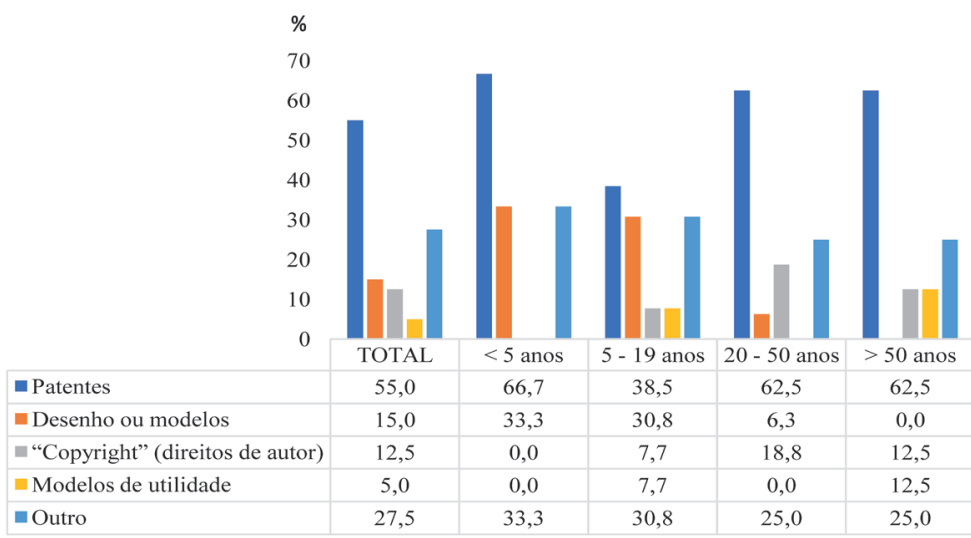

Fonte: Questionário EFs. 
Todo o processo de certificação de qualidade envolve, necessariamente, mudanças na empresa. Essas mudanças passam não só pelas alterações ao nível de processos e estruturas, mas também nos comportamentos. As empresas familiares, por serem consideradas pouco abertas e resistentes à mudança, poderão apresentar-se mais relutantes a introduzirem estes processos, mas, por outro lado, as pressões de mercado podem levá-las a implementar essa gestão da qualidade.

Dado o interesse crescente das empresas em assegurar uma produção de alta qualidade para se diferenciarem positivamente no mercado têm surgido vários sistemas suportados em normas de gestão. Uma das normas mais conhecidas e utilizadas é a NP EN ISO 9001: $2015^{35}$, cujo principal intuito é ser usada pelas empresas como um guia de implementação de um Sistema de Gestão da Qualidade reconhecido.

$\mathrm{Na}$ amostra de empresas familiares observa-se que apenas $27,4 \%$ possuem certificação de qualidade, sendo uma caraterística das empresas de maior dimensão visto que mais de metade delas possuem esta certificação (63,2\%), a qual alcança os $37 \%$ nas pequenas empresas. Como expectável, regista-se um maior envolvimento das empresas mais antigas nos processos de certificação da qualidade (Gráficos 50 e 51).

\section{GRÁFICO 50. Certificação de qualidade por dimensão}

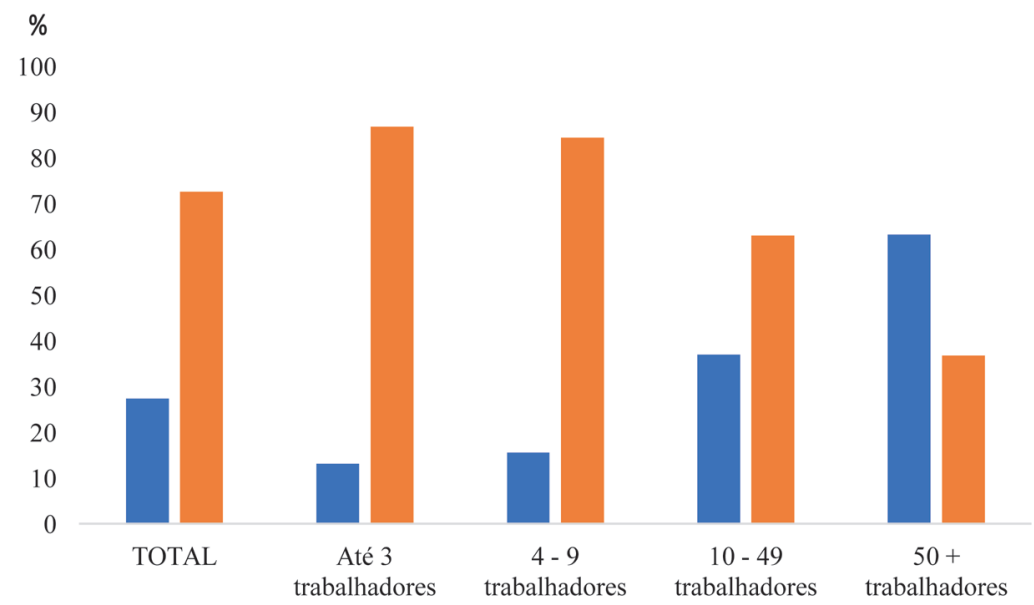

Fonte: Questionário EFs.

35 Para mais informação consulte o sítio do Instituto Português da Qualidade (http://www1.ipq.pt/pt/ipq/qualidade/sgq/Paginas/SGQ aspx). 


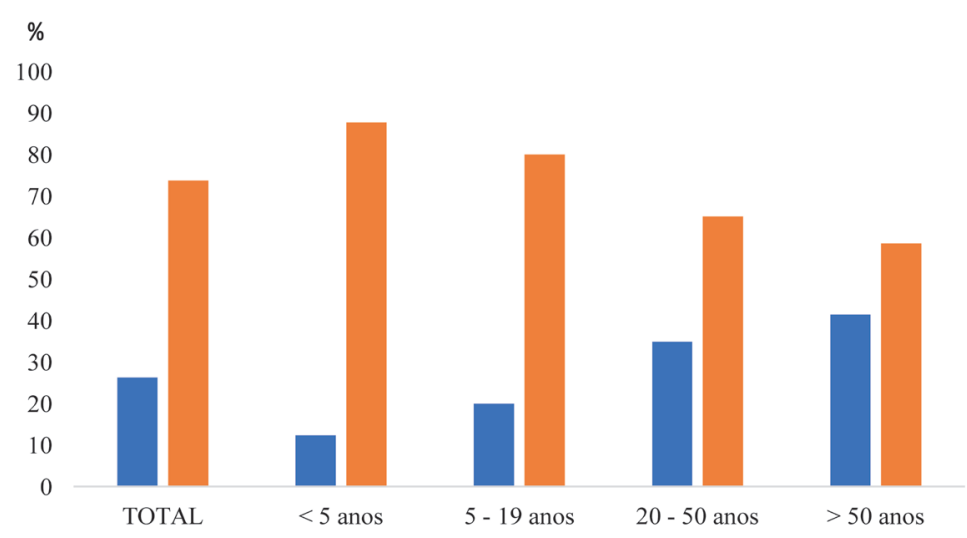

Fonte: Questionário EFs.

Refira-se, ainda, que algumas empresas familiares declararam possuir outras certificações como, por exemplo, "PME- Excelência", "PMELíder", "Higiene/ Segurança no trabalho", bem como certificações específicas relacionadas com a área de negócio em que se encontram envolvidas.

O desenvolvimento sustentável e a responsabilidade ambiental são temas que preocupam as sociedades e desafiam as economias a integrá-los na sua filosofia e orientação estratégia para o negócio. Como já referido, as empresas familiares tendem a adotar uma orientação de longo prazo com vista a poderem passar para as gerações seguintes o legado de um negócio rentável. Estas empresas tendem a estabelecer laços fortes com os seus stakeholders e são mais relutantes na adoção de comportamentos que possam ser prejudiciais para o bem-estar social. Nesse sentido, as empresas familiares tendem a desenvolver estratégias empresariais que defendem o meio ambiente e também contribuem para a sustentabilidade da empresa a longo prazo.

Avaliando algumas políticas de preservação ambiental que possam estar ou não a ser seguidas, a análise seguinte evidencia que as políticas de preservação ambiental em causa são profusamente seguidas pelas empresas, sendo relativamente independentes quer da dimensão, quer da antiguidade da empresa. Estas são: políticas de reciclagem do material (94,2\%), tratamento de resíduos (92,4\%) e dos recursos que consomem (89,8\%), preservação ambiental na produção e distribuição dos produtos/serviços (83,8\%) (Gráfico 52).

Em síntese, tendo em conta os últimos anos, poucas são as empresas familiares que se encontraram envolvidas em processos de inovação e as que o fizeram, os resultados dessa inovação traduziram-se diretamente na introdução de novos produtos e/ ou serviços, pelo registo de patentes 


\section{GRÁFICO 52. Políticas de preservação ambiental seguidas pela empresa familiar}

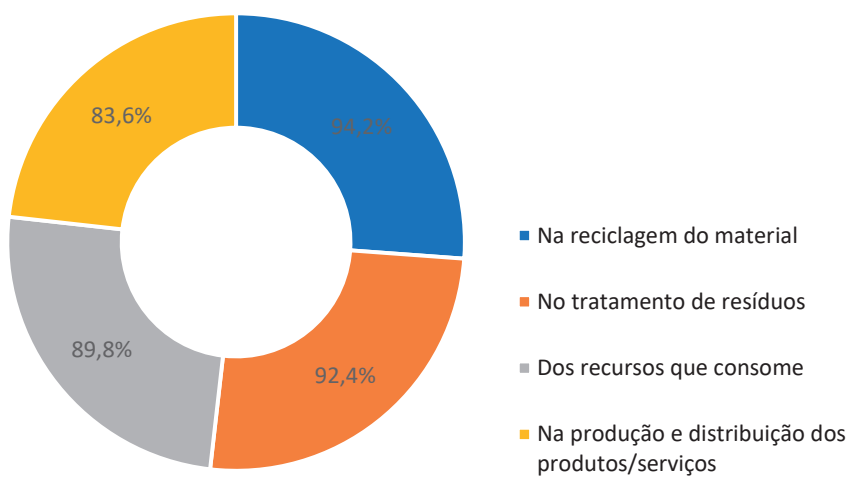

Fonte: Questionário EFs.

ou, de forma indireta, pela melhoria dos processos na criação de valor. Do perfil das empresas, importa registar o maior protagonismo por parte de empresas de maior dimensão, bem como as que se encontram mais consolidadas no mercado em termos de antiguidade. De realçar que em empresas com menos de cinco anos envolvidas na inovação, estas têm investido exclusivamente no registo das patentes.

Por sua vez, apesar da importância que na atualidade a certificação da qualidade tem, os resultados são reveladores de uma posição ainda frágil a este nível. Menos de 30\% das empresas familiares têm sistemas de gestão de qualidade suportados em normas e integradas na sua cultura organizacional como valores essenciais da empresa. Igualmente, as empresas familiares têm vindo a adotar sistemas de reciclagem e tratamento de resíduos, integrando-os largamente nas suas políticas de preservação ambiental. Estas constituem-se cada vez mais num fator de valorização que o consumidor faz do produto final que poderá ser explorado numa perspetiva mais altruísta ou de marketing social, mas também essencial para garantir uma eficiente utilização dos recursos e assim contribuir, de forma mais direta, para a rentabilidade da empresa.

\subsection{Recursos humanos, formação e avaliação}

Para Morgan (1986: 139), a cultura da organização ${ }^{36}$ constitui um sistema de valores fundamentais de códigos e representações, que estão na base da tomada de decisão, na definição de objetivos e que orientam os comportamentos

36 Trata-se de um conceito multidimensional, pelo que a complexidade temática interpela para uma discussão mais alargada que ultrapassa os propósitos deste estudo. 
quotidianos dos trabalhadores. Por isso, importa convocar este conceito à luz dos valores, símbolos, histórias, cerimónias, rituais e padrões de comportamento "tribal" que decoram e dão sentido a uma organização, muito em especial quando se trata de uma empresa familiar profundamente imbuída do "carisma", "rosto" e "espírito empreendedor" do(a) fundador(a) da mesma.

Mas também são os recursos humanos que configuram a cultura organizacional enquanto fator de diferenciação entre empresas com sucesso. As empresas familiares tendem a ter melhor ambiente de trabalho e maior harmonia, fruto da existência de elevados níveis de confiança. Os valores da lealdade, compromisso e confiança são valores partilhados e comuns às empresas familiares que, aliado ao forte investimento e envolvimento na formação dos trabalhadores, conduzem ao forte poder de atração que estas empresas podem ter no mercado de trabalho. É certo que também podem ter um efeito adverso. Ou seja, se prevalecer uma cultura e ambiente organizacional assente em práticas de nepotismo ou paternalismo, acompanhado por estratégias de recrutamento e gestão de carreiras assente em critérios informais (sobretudo afetivos e de laços de parentesco e capital social), estas empresas podem ter dificuldades em atrair e fixar profissionais competentes (UE, 2009).

Atendendo à descrição do número de trabalhadores ao serviço (contando com os gestores), por referência a 2016, importa registar dois factos: 1) percentagens relativas de empresas que declararam ter só trabalhadores mulheres (11,6\%) ou só trabalhadores homens (8,9\%), evidenciando uma feminização ou masculinização do perfil das empresas em causa; e 2) proporção relativa de mulheres e homens em função da dimensão das empresas (Gráfico 53).

GRÁFICO 53. N$^{\circ}$ de trabalhadores ao serviço mulheres e homens (contando com os gestores), em 2016

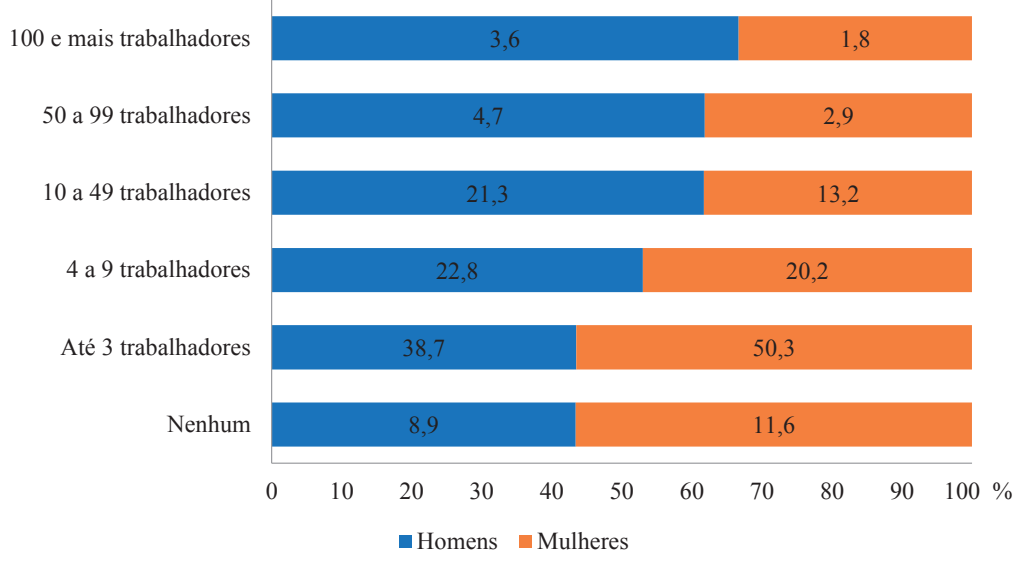

Fonte: Questionário EFs. 
Na análise da evolução da criação de emprego nos últimos três anos, apenas 9,3\% das empresas diminuíram o número de trabalhadores, enquanto 47,8\% estabilizaram e 42,9\% aumentaram. As evoluções mais positivas no número de trabalhadores ocorreram nas empresas de maiores dimensões, $67,7 \%, 63 \%$ nas pequenas empresas e 40,3\% nas empresas de 4 a 9 trabalhadores (Gráfico 54). As empresas que registaram evoluções positivas no número de trabalhadores foram, proporcionalmente mais as que existem entre 20 a 50 anos (46,5\%) e entre 9 e 19 anos $(45,4 \%)$ (Gráfico 55) ${ }^{37}$.

Reportando-se, agora, apenas ao último ano, o recrutamento de novos trabalhadores ocorreu em $56,6 \%$ dos casos, tendo estes recrutamentos sido registados principalmente entre as pequenas (86,5\%) e médias e grandes $(92,9 \%)$ empresas, como seria expectável. (Gráfico 56).

GRÁFICO 54. Evolução do número de trabalhadores nos últimos três anos, por dimensão

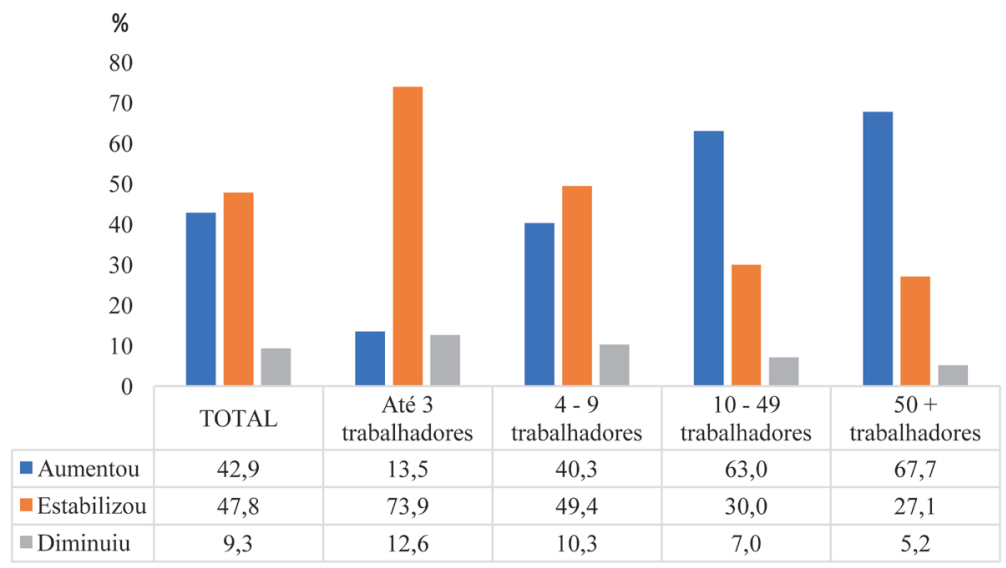

Fonte: Questionário EFs.

37 Ainda que para ano distinto, refira-se que para as empresas do Norte e com referência a 2013, o número de empregados aumentou cerca de 9,5\% (Pessoas ao Serviço, INE Indicadores Demográficos das Empresas não Financeiros em Portugal, 2008-2016). 


\section{GRÁFICO 55. Evolução do número de trabalhadores nos últimos três anos, por antiguidade}

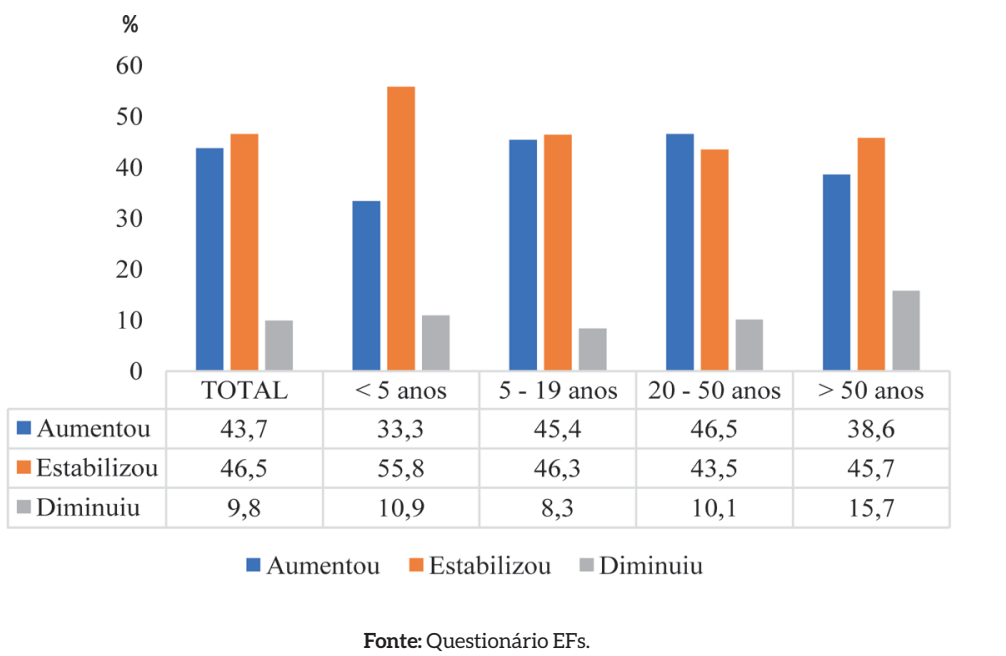

GRÁFICO 56. Recrutamento de novos trabalhadores na empresa no último ano, por dimensão

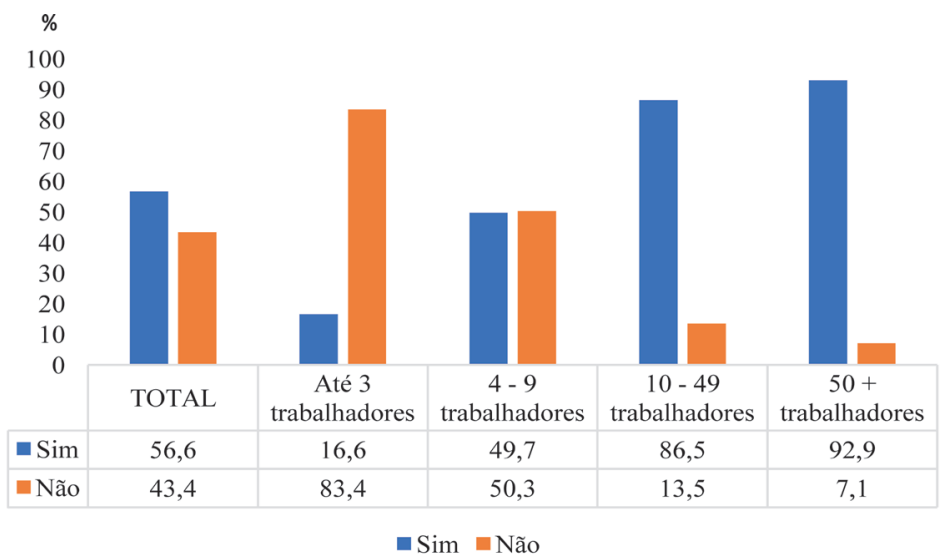

Fonte: Questionário EFs. 
A capacidade de criação de emprego por parte das empresas familiares tem sido devidamente sinalizada como um dos fatores que relevam a sua importância. Refira-se, a este propósito, o estudo da Edelman Trust Barometer (2017), que apresenta dois dados muito expressivos: menos de 1 em cada 3 dos participantes veem a empresa familiar como geradora de empregos, quando cerca de 50\% a 80\% dos empregos são criados pelas sociedades familiares, o que denota uma excelente oportunidade de melhoria da comunicação das empresas relativamente a este relevante indicador.

Em Portugal, perante o contexto de crise financeira e económica entre 2011 e 2015, sob o Memorando da Troika, ressalve-se a importância destas empresas na estabilização da sua mão de obra (em muitos casos, com fortes custos internos à gestão da mesma), mas, mais importante, na criação de emprego numa conjuntura adversa.
Entre os novos trabalhadores recrutados no último ano, as empresas procuraram sobretudo trabalhadores com experiência profissional, independentemente da idade (50,3\%). Todavia, também foram procurados jovens, independentemente de terem ou não experiência (32,9\%), jovens com qualificações técnico-profissionais ajustadas ao negócio da empresa (30,8\%) e ainda jovens com qualificações académicas superiores $(20,6 \%)$ (Gráfico 57). A experiência profissional dos trabalhadores é privilegiada por todas as empresas, mas sobretudo pelas micro empresas e empresas de maior dimensão. Trabalhadores com idades mais jovens também são procurados pela generalidade das empresas, embora com maior ênfase nas empresas de maior dimensão. Entre estes, é interessante notar o menor relevo que é dado aos jovens qualificados, tanto corresponda a uma qualificação académica superior, como a uma qualificação técnico-profissional ajustada ao negócio.

\section{GRÁFICO 57. Tipo de trabalhador procurado pela empresa}

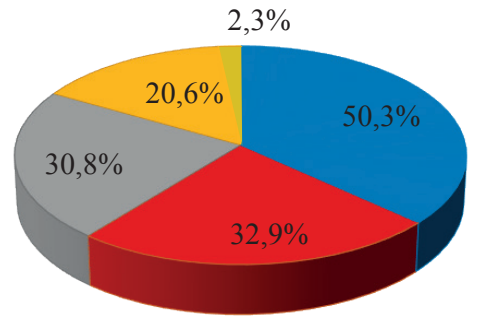

\author{
Trabalhadores com \\ experiência \\ profissional \\ - Jovens, com ou sem \\ experiência
$\square$ Jovens com qualificações técnico- profissionais
Jovens com qualificações
Outro \\ académicas superiores
}


Pautadas pela existência de laços de confiança mútua entre proprietários e empregados, um outro traço caraterístico destas empresas passa pela quase ausência de dispositivos formalizados de avaliação de desempenho dos recursos humanos. A lealdade e a dedicação tendem a sobrepor-se ao nível de qualificação ou à produtividade dos trabalhadores. Apenas 22,8\% das empresas possuem um plano formal de avaliação de desempenho dos trabalhadores que se encontra associado à dimensão da empresa: quanto maior é a empresa mais provável é existir o referido plano, o qual existe em 39,4\% das médias e grandes empresas (Gráfico 58).
Entre as empresas que possuem um plano formal de avaliação de desempenho, este assenta fundamentalmente em critérios como, produtividade (58,8\%), pontualidade/assiduidade $(53,1 \%)$ e cumprimento dos objetivos definidos para a função/cargo (51,9\%). Em contrapartida, no polo oposto, entre os critérios que são menos privilegiados, encontram-se a partilha dos valores e cultura da empresa (15,3\%), o desenvolvimento de novas competências $(17,6 \%)$ e a disponibilidade para realizar horas extraordinárias (21,8\%) (Gráfico 59).

Embora a ordem com que se privilegiam estes

\section{GRÁFICO 58. Plano formal de avaliação de desempenho dos trabalhadores por dimensão}

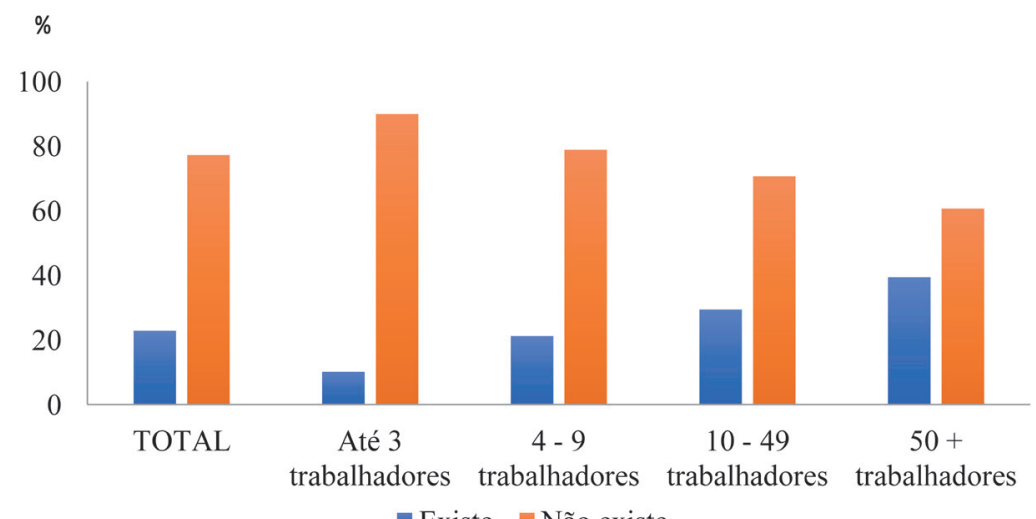

घ Existe $\quad$ Não existe

Fonte: Questionário EFs. 
GRÁFICO 59. Critérios privilegiados na avaliação de desempenho por dimensão

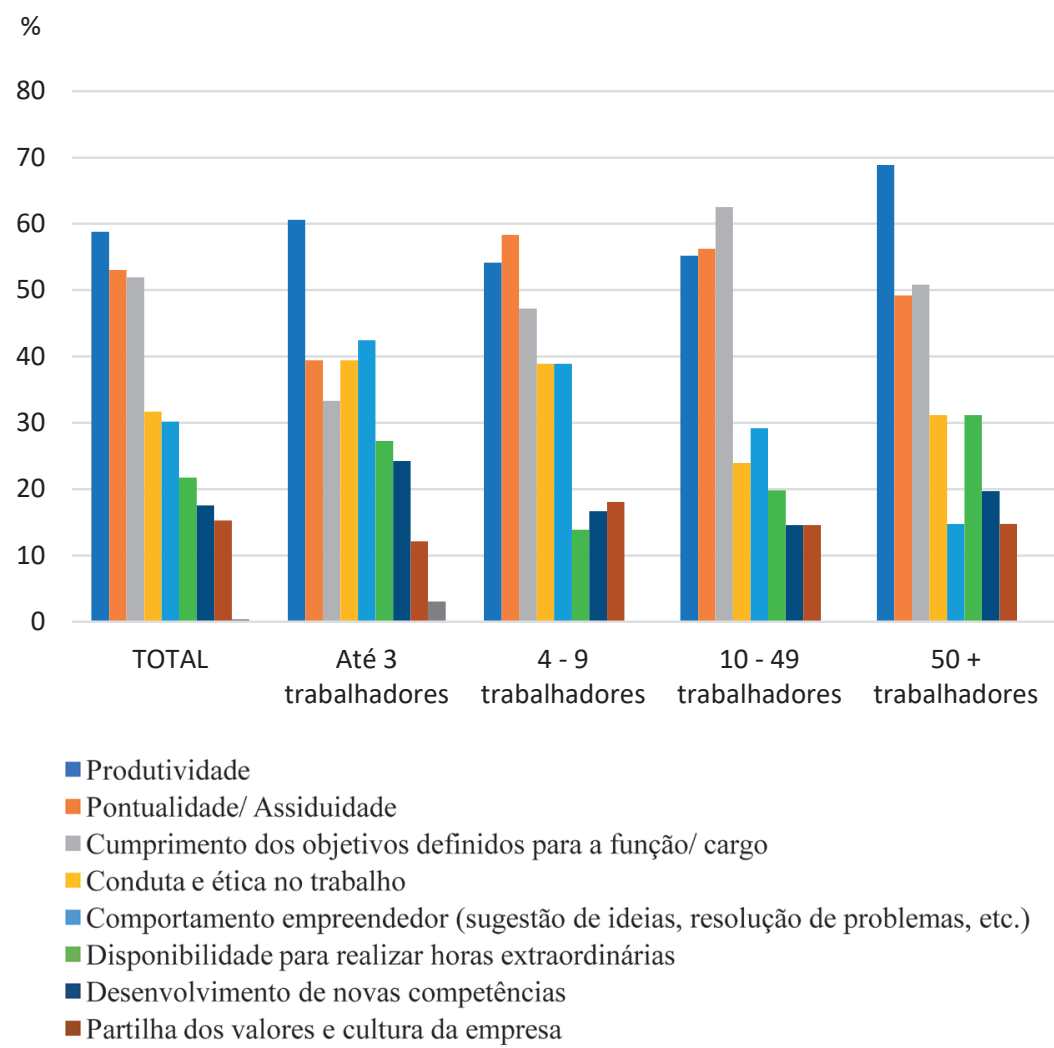

Fonte: Questionário EFs.

critérios na avaliação de desempenho varie em função da dimensão da empresa, destaca-se a coincidência da produtividade como critério principal nas empresas até 3 trabalhadores $(60,6 \%)$ e nas médias e grande empresas (68,9\%), enquanto nas empresas entre 4 a 9 trabalhadores o critério mais privilegiado seja a pontualidade/assiduidade (58,3\%) e nas pequenas empresas o cumprimento dos objetivos definidos para a função/cargo (62,5\%). Entre os três principais critérios na avaliação do desempenho, saliente-se a importância do comportamento empreendedor, a sugestão de ideias, a resolução de problemas, entre outros (42,4\%), em detrimento do cumprimento dos objetivos definidos para a função/cargo (33,3\%).

Nem todas as empresas que possuem um plano formal de avaliação de desempenho dos trabalhadores aplicam as consequências decorrentes dessa avaliação, pois apenas 70,6\% respondem afirmativamente (Gráfico 60). A aplicação de consequências decorrentes da avaliação de desempenho é mais frequente nas pequenas empresas $(80,2 \%)$ e menos frequente nas empresas até três trabalhadores $(57,6 \%)$. 


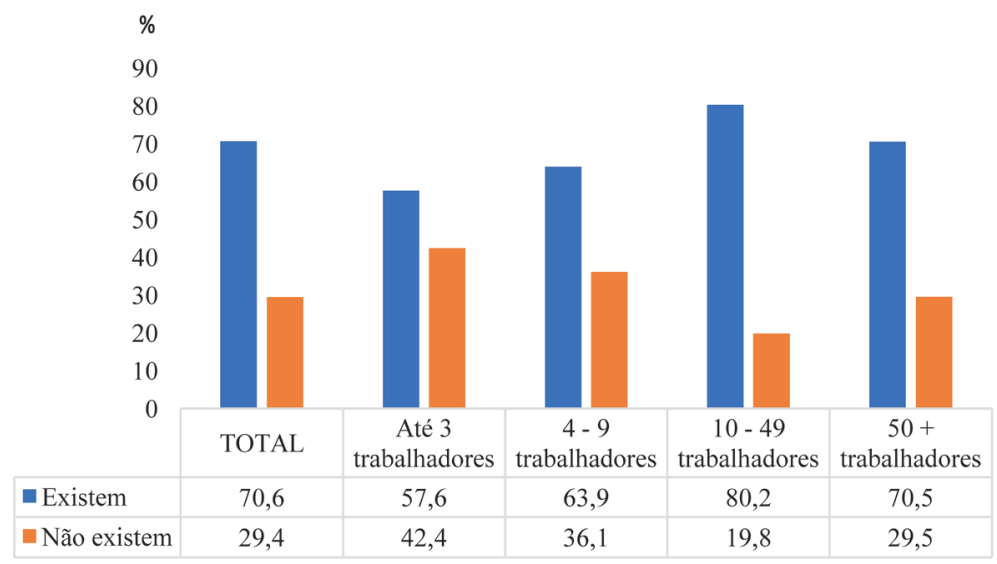

Fonte: Questionário EFs.

Entre as empresas que aplicam as consequências decorrentes da avaliação de desempenho (Gráfico 61), destacam-se a atribuição de prémios de produtividade (66,5\%) e o aumento/promoção salarial (47,6\%). Outras consequências são o apoio à formação contínua interna ou externa à empresa $(30,8 \%)$ e a progressão na carreira $(25,4 \%)$, embora seja pouco frequente proporcionar o acesso a benefícios sociais, como seguros de vida (7\%). No caso das médias e grandes empresas destaca-se a progressão na carreira (34,9\%) como uma das três principais consequências decorrentes da avaliação de desempenho, enquanto no caso das empresas até 3 trabalhadores o acesso a benefícios sociais $(21,1 \%)$ ser também uma consequência considerada.
As empresas familiares, em especial as de primeira geração, como veremos mais à frente, são caraterizadas por elevados níveis de informalidade na tomada de decisão (na maioria das vezes muito centrada no fundador). A gestão dos recursos humanos não é exceção e é habitual verificar que neste tipo de empresas as políticas de avaliação de desempenho e os sistemas de remuneração com base em critérios objetivos são raros. Apesar da vertente familiar que carateriza estas organizações, importa que a empresa familiar se profissionalize no sentido de adotar também critérios imparciais para medição do desempenho dos trabalhadores, sendo englobados nessa avaliação também os membros da família. 
GRÁFICO 61. Tipo de consequências decorrentes da avaliação de desempenho por dimensão

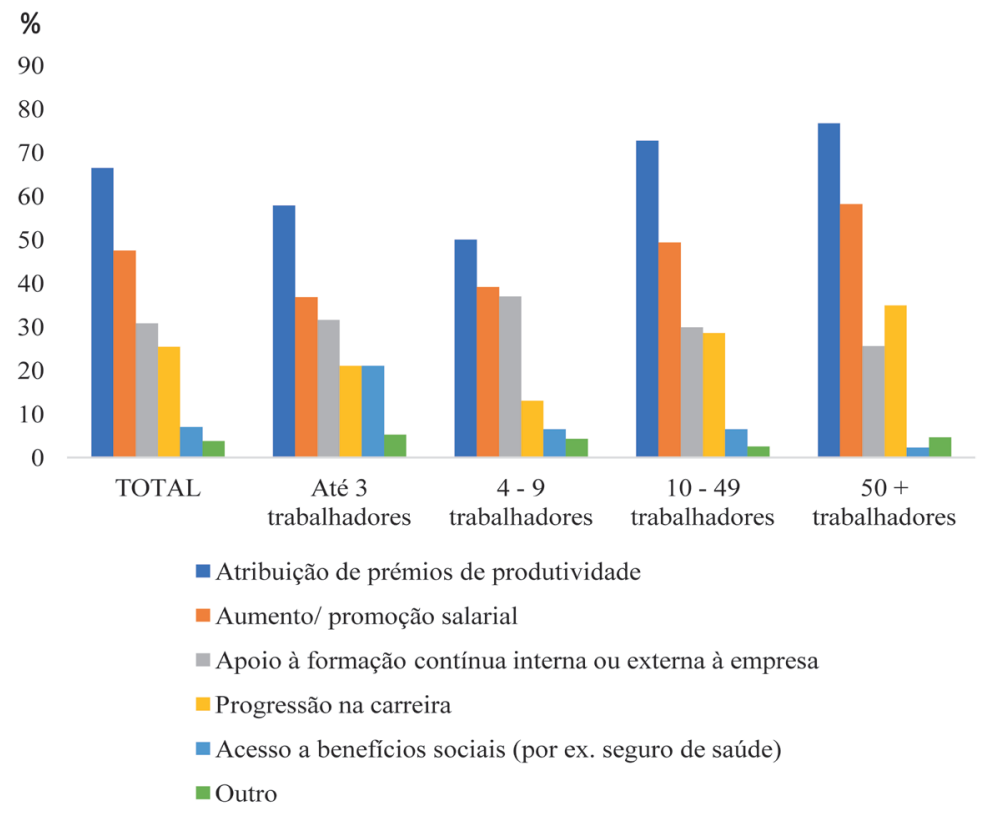

Fonte: Questionário EFs.

\subsection{Governação e profissionalização da Empresa Familiar}

A estrutura de governance das empresas familiares pode ser uma forma de conseguir alavancar a vantagem competitiva face à concorrência, salvaguardando-a de eventuais conflitos e protegendo a harmonia no seio familiar. Este equilíbrio é cada vez mais importante, pois protege a família e assegura a continuidade da empresa. Isto implica definir a separação entre as duas dimensões, com a introdução de processos formais que determinem com clareza como a família irá se relacionar com a empresa, como também definir quando, e em que medida, a família é informada sobre o que se passa no âmbito da empresa familiar. Não existem mecanismos de governance que sejam universais e aplicáveis de forma idêntica a todas as empresas familiares. Com o crescimento da empresa (e da família), importa ajustar os mesmos para assegurar uma adequação ao seu crescimento sustentável. Neste processo, importa considerar o papel do(a) fundador(a), a estrutura de governação, a preparação da "nova" geração e os mecanismos de sucesso da empresa familiar.

\subsubsection{Papel do(a) fundador(a)}

$\mathrm{O}$ (a) fundador(a) da empresa familiar é o vértice entre a família e o sistema de gestão, e tem um papel central em ambos (Sundaramurthy \& 
Kreiner, 2008; Litz, 2008; Tagiuri \& Davis, 1982). Este imprime a sua marca desde o início da empresa familiar através da definição da missão, do contexto das operações da empresa, da escolha dos membros e do funcionamento da organização como um todo. Compete-lhe definir a organização empresarial e resolver problemas de integração interna e de adaptação externa.

Numa fase inicial da empresa familiar, o(a) fundador(a) tem uma posição única e privilegiada na criação da identidade cultural base da organização impondo os seus valores e crenças. A socialização e o legado familiar, a trajetória escolar e profissional, além dos traços de personalidade e "espírito empreendedor" marcam a visão do(a) fundador(a) e a missão da empresa familiar, funcionamento e cultura da organização. Consequentemente, o seu protagonismo é crucial na determinação da configuração e determinação da organização, sua continuidade e sustentabilidade.

É de relevar o papel preponderante do(a) fundador(a) que, apesar de remontar ao início da vida da empresa, tende a manter-se presente através da sua intervenção ativa e do papel preponderante na gestão da mesma. Na amostra das empresas familiares participantes do estudo analisou-se em que geração a empresa se encontra e qual o número de gerações ativas na gestão ou trabalho.

Os resultados indicam a presença maioritária da primeira geração $(60,9 \%)$ à frente ainda nas funções da empresa, não obstante quase um terço $(29,4 \%)$ fazer parte já da $2^{\text {a }}$ geração em funções. Os valores relativos à terceira e quarta geração são bastante menores, sendo, respetivamente, $7,8 \%$ e 1,4\%. Todavia, a geração mais antiga em funções na empresa está indissociavelmente ligada à respetiva dimensão, pois entre as empresas até três trabalhadores a representatividade da primeira geração sobe para $77,9 \%$, a qual decresce progressivamente com o aumento da dimensão da empresa, enquanto a percentagem de empresas com a segunda geração em funções cresce com o aumento da dimensão da empresa. Por seu lado, as empresas com a terceira ou quarta geração em funções são principalmente as de maior dimensão (13,6\% destas referem-se à quarta geração). Como se verifica a existência de uma relação entre a antiguidade e a dimensão da empresa, era expectável observar gerações mais antigas nas empresas de maior dimensão e idade (Gráfico 62).

Nas empresas familiares portuguesas estão em plena atividade, seja em trabalho ou na gestão, uma ou duas gerações $(51,0 \%$ e $46,1 \%$, respetivamente). Contudo, mais uma vez, as diferenças sobressaem em função da dimensão da empresa. Se, por um lado, encontramos $74,8 \%$ das empresas até três trabalhadores com apenas uma geração ativa, também verificamos que $65,8 \%$ das maiores empresas têm duas gerações ativas, o mesmo acontecendo em $59,3 \%$ das pequenas empresas. Refira-se, ainda, que 7,1\% das maiores empresas têm três gerações em plena atividade. O mesmo se passa se consideramos os anos de existência da empresa, evidenciando a coexistência de duas ou mais gerações nas empresas com maior antiguidade (Gráfico 63). 
GRÁFICO 62. Geração mais antiga em funções por dimensão

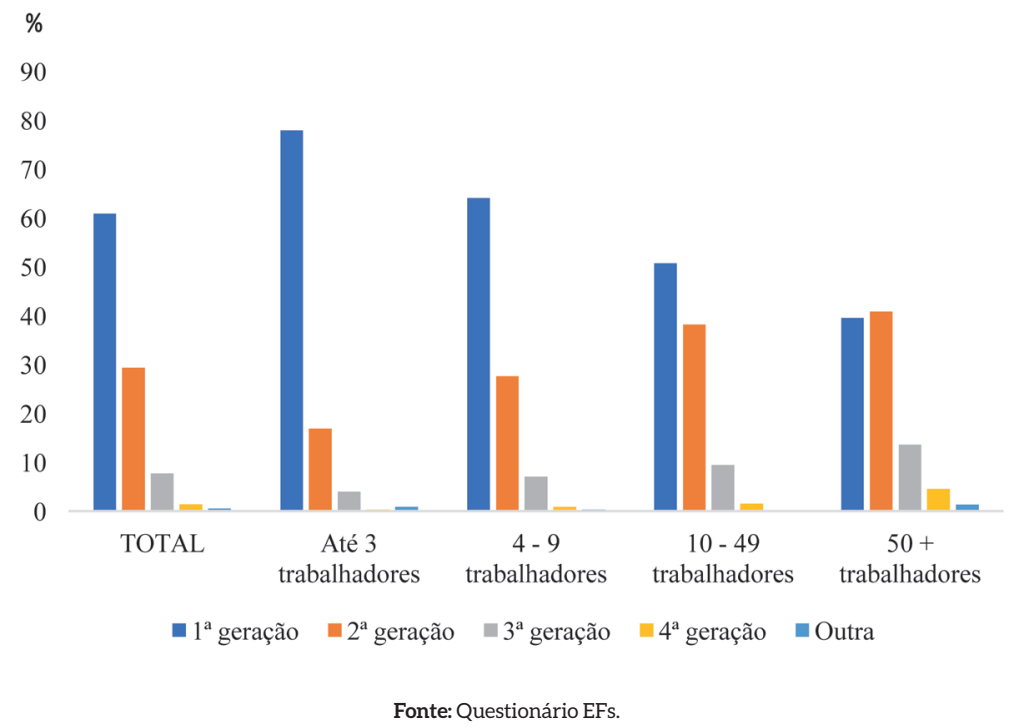

GRÁFICO 63. Gerações ativas (trabalho ou gestão) por dimensão

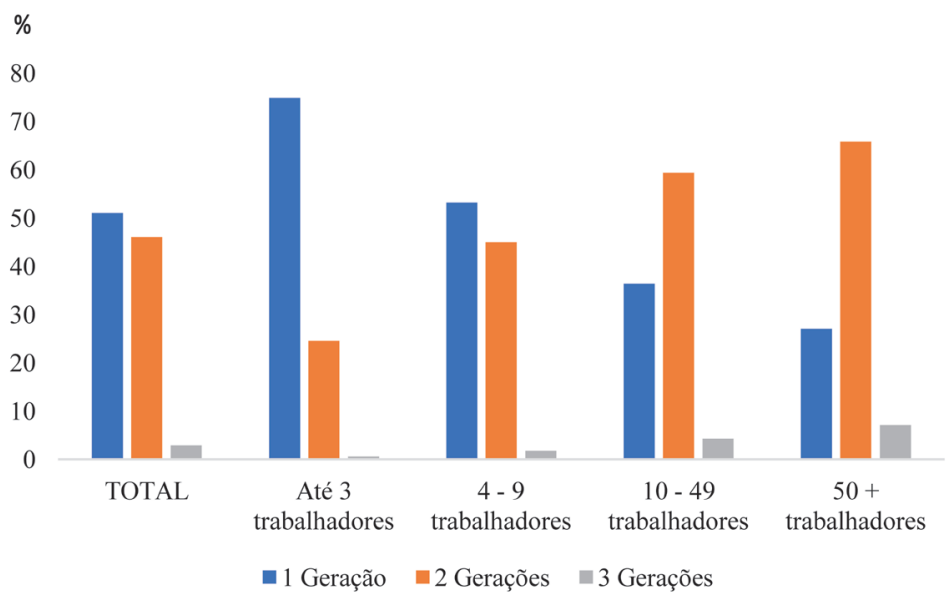

Fonte: Questionário EFs. 
Ao se analisar o perfil de quem foi o(a) fundador(a) da empresa, reforça-se a importância do "rosto" da empresa familiar se manter à frente dos seus destinos (Gráfico 64). Com efeito, o atual responsável da empresa foi o respetivo fundador em $61,9 \%$ das empresas, seguido do pai ou mãe $(25,6 \%)$.

Fica patente que a permanência das empresas ao longo das gerações constitui um dos principais desafios e especificidades desta tipologia empresarial. Os nossos resultados apresentam uma tendência mais crítica a este nível, reforçando o argumento já avançada da importância do planeamento estratégico, designadamente a preparação da sucessão empresarial.

Com efeito, os estudos internacionais e nacionais apontam para estimativas muito baixas de sobrevivência destas empresas à terceira ou mais gerações, como tivemos já oportunidade de o referir. Igualmente, no estudo coordenado pela AEP sobre o "Livro Branco da Sucessão" (2011), as percentagens rondavam os $20 \%$. Por sua vez, se atendermos à estrutura empresarial portuguesa não familiar, observa-se, em geral, a dificuldade de formação de "dinastias industriais" (Lisboa, 2002), no sentido em que estas tendem a não resistir a mais de três décadas. É certo que esta análise se circunscreve ao setor da indústria transformadora que, como se sabe, para o seu arranque e crescimento, pressupõe avultados investimentos de capital para ancorar toda uma organização taylorista/ fordista de produção em série. Com as reestruturações tecnológicas e organizacionais recentes, desde a flexibilização produtiva à subcontratação/ outsourcing, difundem-se modelos de organização próximos de empresas "magras" como resposta ao mercado competitivo internacional. Tal tem vindo a se

\section{GRÁFICO 64. Fundador(a) da empresa}

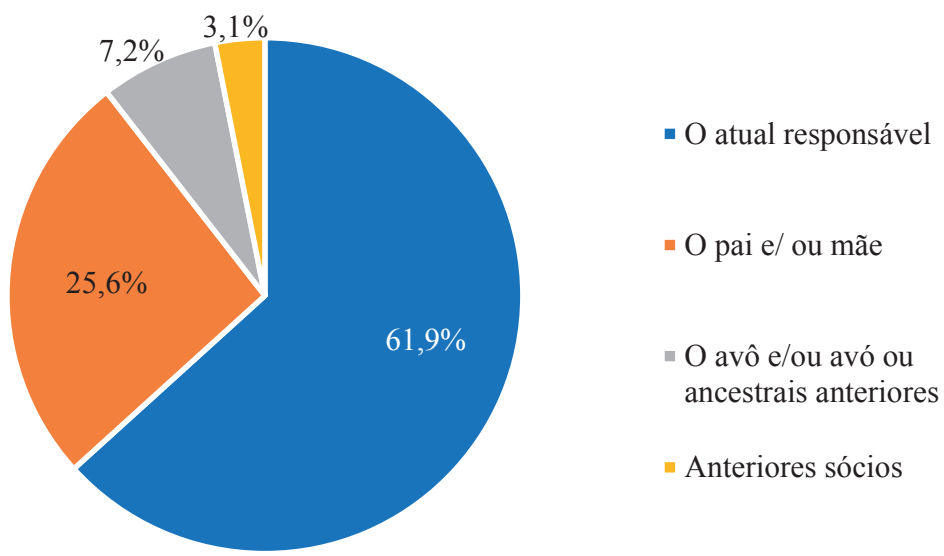

Fonte: Questionário EFs. 
constituir, de certa forma, num incentivo ao aparecimento de muito mais empresas, ainda que a sua vulnerabilidade seja potencialmente mais acentuada e as e condições contratuais mais precárias, face a um passado próximo.

Entre as empresas cujo respetivo fundador(a) foi o atual responsável, primeira geração, procurou saber-se qual a razão que teria estado na origem da sua criação (Gráfico 65). Embora algumas das razões tivessem estado associadas a uma alternativa para sustentar a família e ao desenvolvimento da localidade/região, sobressaem como principais razões a oportunidade de negócio $(47,2 \%)$ e a necessidade de criar o próprio emprego (37,8\%). Interessante também é perceber que na "outra" razão, aquela tendência de autonomização e criação do projeto empresarial surge reforçada, quer pela experiência e gosto acumulado na área de negócio ("empreendedorismo”, "arriscar um negócio próprio", "gosto pela área", "conhecimento técnico na área", "concretização de um sonho", "não ter mais patrões", etc.), quer pela "continuidade do negócio de família" ou inclusão de "familiar recém-licenciado no projeto", quer, ainda, como estratégia de complemento de recursos financeiros ou de ocupação do tempo na reforma ("ocupação do tempo na aposentação", "preparar uma reforma ativa e complemento aos rendimentos existentes", "aliviar o stress", etc.).

Metade das empresas até três trabalhadores $(50,4 \%)$ aponta a criação do próprio emprego como primeira razão, aparecendo a oportunidade de negócio como segunda razão (32,4\%). Já nas restantes empresas, a oportunidade de negócio como razão cresce com a dimensão da empresa (46,3\% nas micro empresas, $61 \%$ nas pequenas empresas e 64,4\% nas maiores empresas). Em

\section{GRÁFICO 65. Razão da criação da empresa pelo(a) fundador(a) por dimensão}

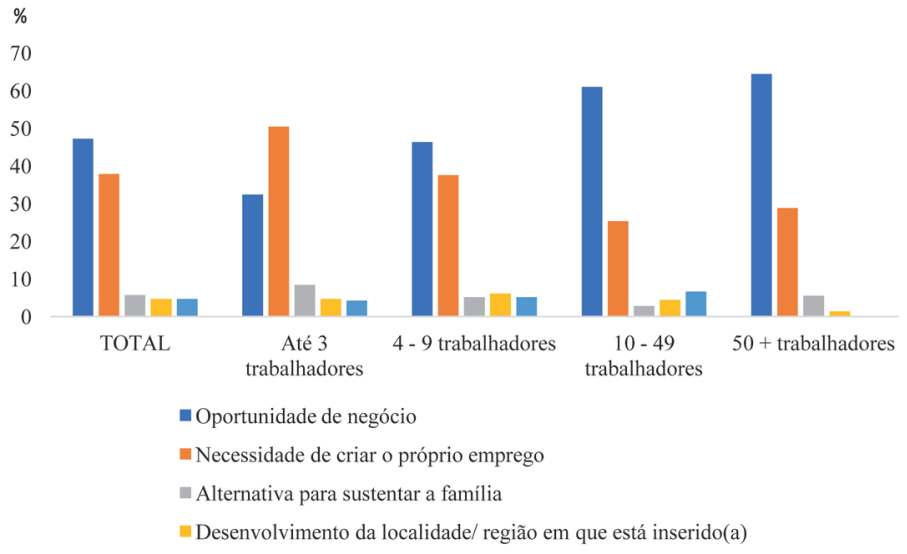

Fonte: Questionário EFs 
sentido inverso, a necessidade de criar o próprio negócio diminui com a dimensão da empresa (37,5\%, 25,3\% e 28,8\%, respetivamente).

Já entre as empresas de segunda ou mais gerações, procurou saber-se o que esteve na origem da opção de entrar na empresa (Gráfico 66). Entre as possibilidades sugeridas, $43,8 \%$ referem que essa opção foi assumida de forma completamente autónoma, 37,1\% adiantam que se tratou de algo incutido desde sempre no seio da família, enquanto para 18,3\% resultou de uma situação inesperada.

Ainda assim são distintivas as razões em função da dimensão da empresa: nas médias e grandes empresas, embora o facto de ter sido incutido desde sempre no seio da família seja um fator preponderante (48,6\%), 44,4\% assumiram essa opção de forma completamente autónoma; já nas pequenas empresas a opção de cariz autónoma foi a principal razão (51,5\%), ao passo que, em $34,1 \%$ dos casos, essa opção foi incutida pela família. Nas empresas de menor dimensão regista-se um maior equilíbrio entre estas três razões.

Na verdade, a estrutura motivacional dos sucessores que entram na empresa familiar fundamenta-se na concretização de um projeto de autonomização profissional e económica e na exposição a um processo de socialização precoce em idades jovens que favorece a sucessão e permite ancorar a compreensão mútua entre os membros da família e o(a) fundador(a).

Fica patente uma dimensão mais empreendedora e intrínseca ao fundador(a) que se materializa na vontade de autonomização por via de um negócio, mas também o papel central de socialização em contexto familiar e respetivo capital

\section{GRÁFICO 66. Razão para entrar na empresa pela segunda e mais gerações por dimensão}

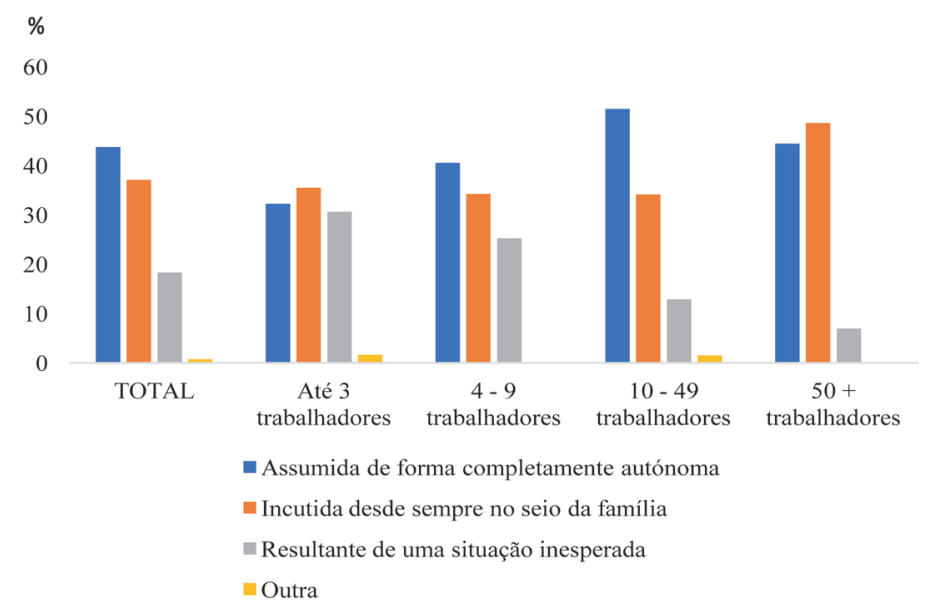

Fonte: Questionário EFs. 
social associado (Couto, 2013; Guerreiro, 1996, 1992; Bourdieu, 2010, 1979). Esta autonomização profissional seja pela criação do seu próprio emprego, seja pela menor disponibilidade para aceitar a dependência hierárquica em termos organizacionais, aproxima o papel do fundador e seus sucessores ao empreendedorismo. A predisposição empreendedora passa pela mobilização de capacidades, experiências e recursos internos à família, já sinalizada na literatura (Rodrigues, 2017; Habbershon \& Pistrui, 2002; Habbershon \& Williams, 1999), e permite reforçar a importância das famílias empresárias na dinamização da economia, considerando-as um motor relevante na inovação, criação de emprego e desenvolvimento da comunidade em que se encontram inseridas.

\subsubsection{Estrutura de governação}

Sabe-se que nas fases iniciais de um negócio familiar tudo (ou quase) é centrado no(a) fundador(a), sem que na maioria das situações seja acompanhado por sistemas formais de gestão. Normalmente a tomada de decisão é centrada nele(a) e como a titularidade e a gestão estão concentrados num número muito reduzido de pessoas da família as decisões tendem a ser finais. A vantagem é claramente a rapidez e a forma informal, como as decisões são tomadas. No entanto, com o crescimento da empresa ao nível dos negócios e da estrutura acionista, é cada vez mais importante haver mecanismos de governance que possam reger o processo de tomada de decisão.

Para compreender o envolvimento da família no negócio, importa atender a um conjunto de indicadores a seguir analisados. Antes de mais, o capital social das empresas familiares é detido maioritariamente por membros familiares (94,3\%), independentemente da dimensão e antiguidade da empresa (Gráfico 67).

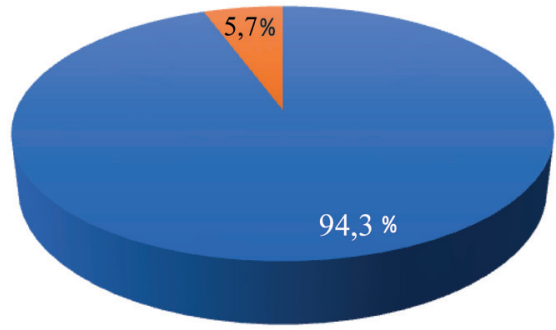

- Sim não

Fonte: Questionário EFs. 
Os graus de parentesco predominantes com o atual responsável pela empresa tendem a se distribuir entre os membros ascendentes (avô/ avó e pai/ mãe) (30\%), descendentes (filho/a e neto/a) (29\%). Numa linha horizontal de parentesco, ressalve-se a presença de relações entre irmão/ã e fundador/a (22\%) e entre cônjuge (17\%). São em número reduzido as relações com afinidade, nomeadamente de genros/ noras, cunhado/ cunhadas, primo/as) (Gráfico 68).
A distribuição da quota do capital social é diversa e segue de perto as relações de sangue, visível no Gráfico 69. Não surpreende por isso que $100 \%$ do capital seja detido pelos membros da família e as proporções de $50 \%$ até $100 \%$ sejam igualmente relevantes. Menos de $50 \%$ do capital detido pela família surge em $20 \%$ dos casos, o que sugere uma relativa abertura do capital social a membros externos à família.

GRÁFICO 68. Grau de parentesco de membros da família com o/a atual responsável

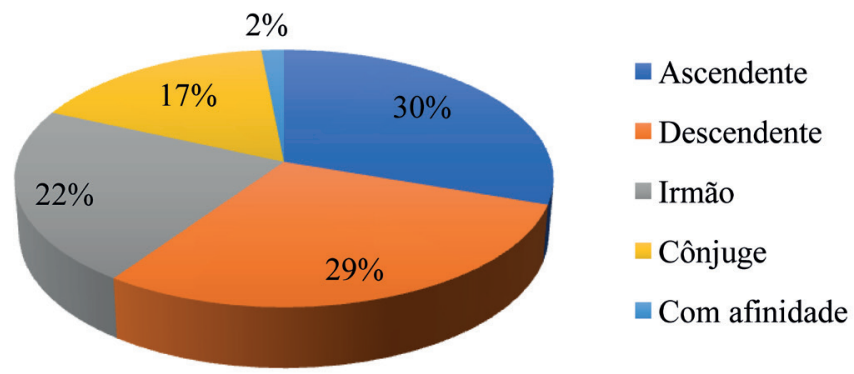

Fonte: Questionário EFs.

GRÁFICO 69. Distribuição da quota (\% aproximada) detida pelos membros da família

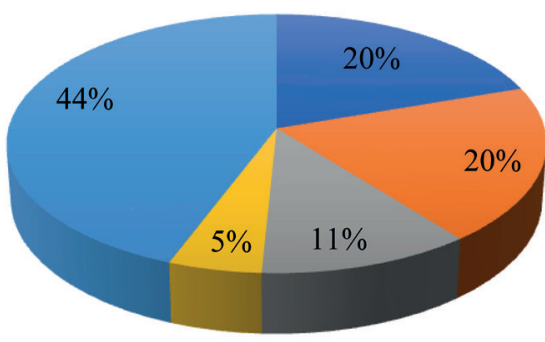

\author{
- Menos de $50 \%$ \\ Exatamente $50 \%$ \\ De $50 \%$ (exclusive) a \\ 90\% (exclusive) \\ De $90 \%$ (inclusive) a \\ $100 \%$ (exclusive) \\ Exatamente $100 \%$
}

Fonte: Questionário EFs. 
À medida que o negócio familiar se expande e se transmite para as gerações seguintes verifica-se a existência de conflitos familiares, devido sobretudo ao distinto foco principal da liderança familiar por geração: enquanto uma empresa familiar de primeira geração é caraterizada por uma constante preocupação do fundador com a manutenção do controlo da família no negócio, a liderança de 2. geração expõe, por sua vez, uma valorização de processos de profissionalização da empresa, equacionando uma maior abertura ao capital social externo, embora em proporções pequenas.
A composição da administração/ gerência por descendentes e por familiares por afinidade (por exemplo, cunhados, genros e noras) e por não familiares reforça o predomínio maioritário de elementos familiares de sangue, sobretudo em funções executivas. Ainda assim, registe-se $22 \%$ de empresas familiares declaram não possuir nenhum trabalhador familiar na sua estrutura de governação (Figura 15). Em lugares de não executivos assinale-se a ausência de familiares descendentes diretos em $72 \%$ das empresas.
$4 \%$

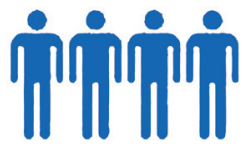

4 ou mais membros
$29 \%$

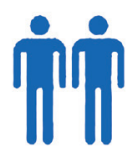

2 membros
$22 \%$

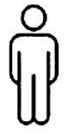

Nenhum membro da família

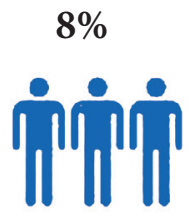

3 membros

\section{$37 \%$}

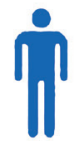

1 membro 
Já quanto à presença de familiares por afinidade, estes não se encontram nas empresas em estudo em $85 \%$ dos casos e em $90 \%$, em funções executivas e não executivas, respetivamente. A ausência de membros não familiares ultrapassa $90 \%$, indiciando o comportamento de reserva, já descrito na literatura. Além disso, privilegiam sobretudo relações de parentesco via laços de sangue na estrutura de governo da mesma.

Ao se atender à questão de género, em 2016, não se regista qualquer membro familiar do sexo feminino na gerência (49\%). Em $43 \%$ dos casos contemplam um elemento do sexo feminino, para além de se registarem algumas situações em que podem ter duas ou mais mulheres (Gráfico 70). Nas funções diretivas, acentua-se a tendência para que nenhum elemento familiar esteja presente (72\%), apesar de se registar $23 \%$ dos casos a presença de uma mulher (Gráfico 71). Esta informação é, em si muito significativa, tendo em conta a maior dificuldade de se atenuar a segregação vertical, ou seja, o acesso a lugares de topo nas empresas em geral por parte das mulheres (Casaca, 2012; Ferreira, 2010).

No contexto internacional, refira-se que a diversidade de vontades quanto a uma sucessão da liderança no feminino, conforme salienta um estudo realizado pela Ernest Young e a Kennesaw State University (2104), onde se questionava se a empresa previa vir a ter como próximo CEO/ Sucessor uma mulher ${ }^{38}$. Numa escala de 1 a 7 , as respostas alcançaram valores de 5 na Espanha e

GRÁFICO 70. Número de mulheres na gerência, em 2016

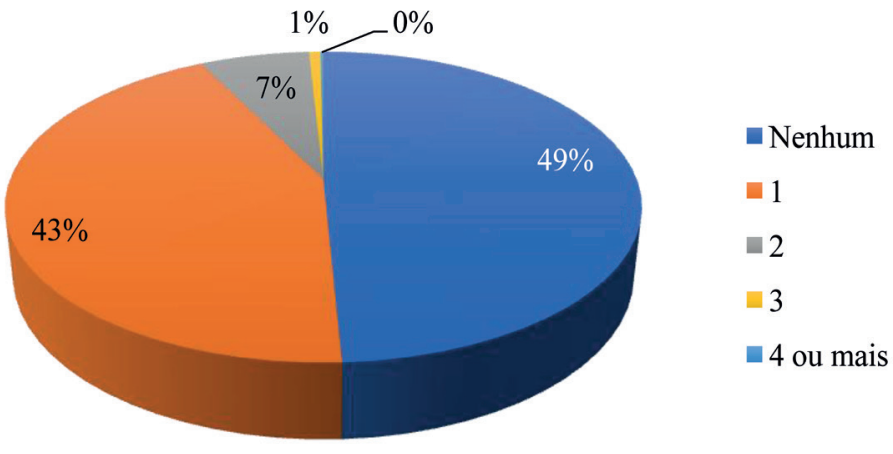

Fonte: Questionário EFs.

38 Trata-se de um relatório baseado em 525 empresas, representando 25 das maiores empresas familiares de 21 dos maiores mercados globais, realizado em 2014. 


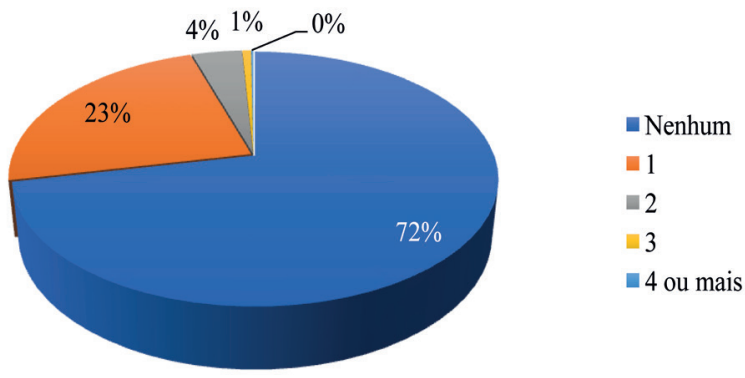

Fonte: Questionário EFs.

Alemanha, 4,5 na Turquia, acima de 3,5 na Holanda, Suíça, Índia e Indonésia e os valores mais baixos ( 3 ou menos) em países como a Coreia do Sul, Canadá, Bélgica, Japão, México e Brasil.

Parece haver nas empresas familiares maior permeabilidade na integração das mulheres, sobretudo tratando-se de descendentes diretos (filhas e netas) e considerando as segundas gerações em coexistência (ou não) com o(a) fundador(a). Tal também se compreende considerando a distribuição das quotas relativas ao capital social da empresa pelos membros da família. Nesse sentido, a maior presença das mulheres na gerência pode estar sobretudo associada ao seu papel de proprietária/ acionista e não tanto relacionado com o desempenho efetivo de funções de gestão ou direção.

Estes valores estão muito para além dos obtidos num estudo da Russell-Reynolds Associates (2014), efetuado junto de 106 empresas não cotadas da Alemanha, Espanha, França e Itália, que, quando questionadas sobre os respetivos conselhos de administração incluía mulheres, referiram a sua presença somente em $10 \%, 17 \%$, $25 \%$ e $15 \%$, respetivamente.
Esta é mais uma das especificidades das empresas familiares quanto à ocupação de distintos papéis e, consequentemente, possíveis zonas de conflitualidade ou "armadilhas" (Costa, Rio \& Rio, 2011) quando se confundem propriedade com gestão, laços de afeto com relações contratuais, relações de sangue com posições hierárquicas na organização, entre outros aspetos.

\subsubsection{Preparação da "nova" geração}

O European Family Business Barometer (KPMG, 2017) antevê que, nos próximos cinco anos, se irá assistir, a nível europeu, à maior transferência de poder e riqueza intergeracional dos tempos modernos. No entanto, a questão da sucessão continua a ser, simultaneamente, um dos pontos críticos e desafios de qualquer empresa familiar, sobretudo pela não preparação do(a) sucessor(a).

Na verdade, este é um tema que não foi ainda devidamente explorado. $O$ processo de sucessão é descrito como um ajustamento mútuo entre o papel do fundador e o da próxima geração. É um percurso evolutivo, com múltiplos períodos, caraterizado por um aumento gradual do 
envolvimento do sucessor e acompanhado por uma diminuição do envolvimento do fundador, que, numa fase final, culmina na transferência de poder entre o fundador e o sucessor (Jayantilal, 2016).

Da nossa amostra torna-se claro que as empresas familiares de Norte do Portugal não são exceção. A existência de expetativas de a empresa vir a realizar uma mudança na gestão, especificamente a sucessão da liderança, entre os próximos 3 a 5 anos, apenas está presente em $22 \%$ dos casos (Gráfico 72). Esta possibilidade é bastante mais reduzida nas empresas até três trabalhadores (14,1\%), nas pequenas empresas (25,7\%) e nas empresas de maior dimensão (27,1\%). Relacionado com a antiguidade das empresas, essa expetativa está mais presente sobretudo nas que possuem entre 20 a 50 anos e mais de 50 anos (Gráfico 73).

Assumindo-se como referência de surgimento de uma geração os 25 anos, estes valores acabam por expressar uma taxa natural de ocorrência de integração de uma nova geração na empresa.

Entre as empresas que admitem uma sucessão da liderança, nos próximos 3 a 5 anos, a principal mudança passará pela entrada da geração mais nova na gestão (74\%), embora se considere em $16 \%$ dos casos a entrada de gestores externos à família (Gráfico 74). Na opção "Outra", foram referidas situações mais específicas, tais como,

GRÁFICO 72. Expetativas de a empresa vir a realizar uma mudança na gestão (sucessão da liderança), nos próximos 3 a 5 anos, por dimensão

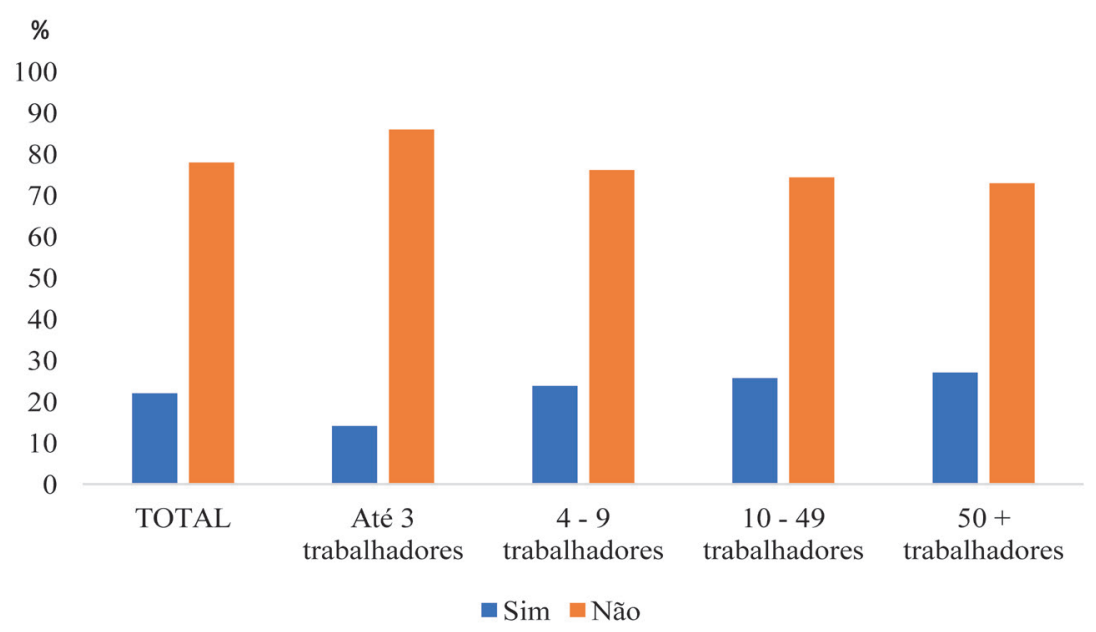

Fonte: Questionário EFs. 
GRÁFICO 73. Expetativas de a empresa vir a realizar uma mudança na gestão (sucessão da liderança), nos próximos 3 a 5 anos, por antiguidade

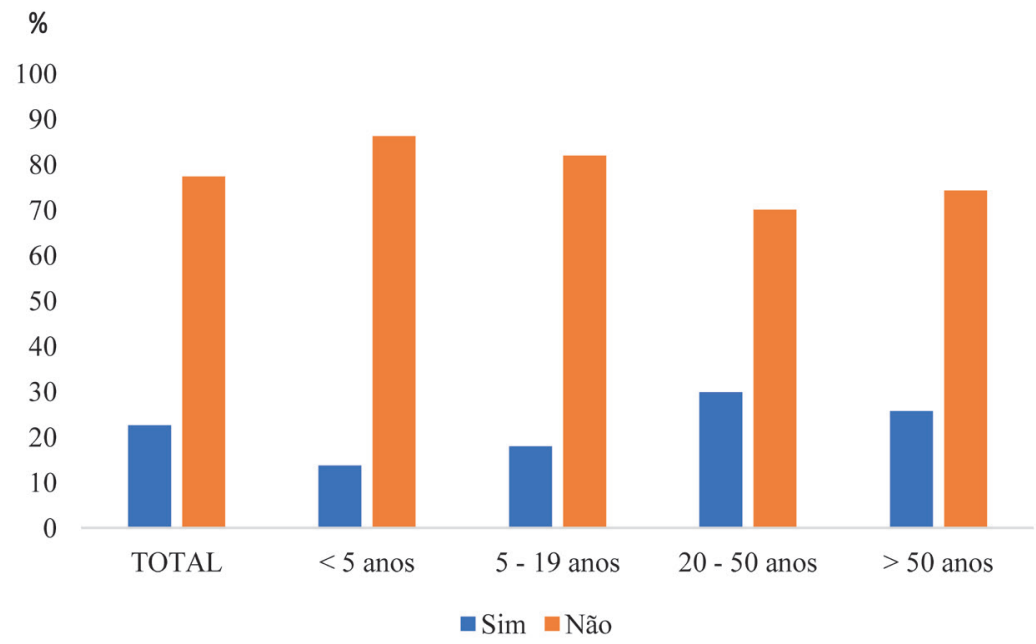

Fonte: Questionário EFs.

GRÁFICO 74. Principal mudança na gestão (sucessão da liderança)

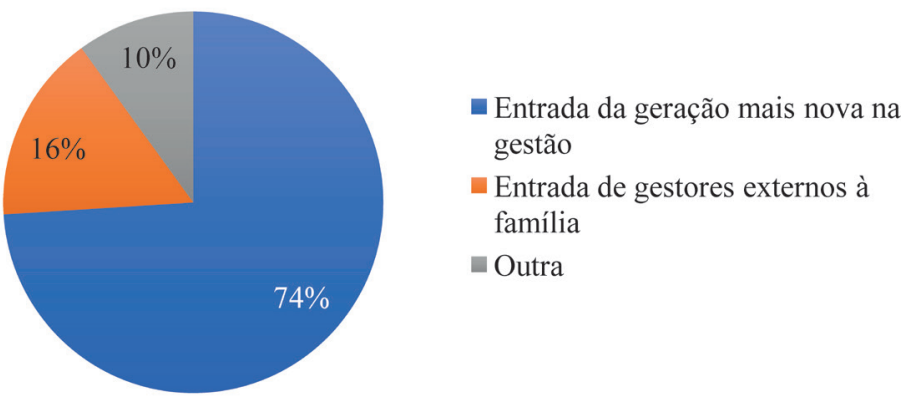

Fonte: Questionário EFs. 
por exemplo: "saída da geração mais antiga", "venda da empresa/ fechar a empresa", "reestruturação financeira e de gestão", "criação de uma nova empresa" e "entrada de investidores internacionais". Tanto em função da dimensão como da antiguidade da empresa, regista-se idêntico perfil de resposta.

No que concerne à existência de expetativas de a empresa vir a realizar uma mudança na estrutura acionista, especificamente na sucessão da propriedade, entre os próximos 3 a 5 anos, não se regista uma grande variação comparativamente com a sucessão da liderança, embora reduzindo-se para $16 \%$ as empresas que o admitem (Gráfico 75). Esta variação reflete uma tendência de dilação e passagem da propriedade por fases, muitas das vezes suportada num sentimento de maior segurança financeira e manutenção de parte do poder (o do acionista) pela geração sucedida.
Todavia, entre as empresas que consideram uma sucessão da propriedade, nos próximos 3 a 5 anos, a mudança passará pela transferência da propriedade entre familiares $(65,2 \%)$, sendo menos provável a abertura do capital social a membros não familiares (17,1\%) ou a venda da empresa (16,6\%) (Gráfico 76). Registe-se que as maiores empresas são aquelas em que referem que a principal mudança na estrutura acionista poderá passar pela transferência da propriedade entre familiares (85,7\%), enquanto as micro empresas se apresentam mais recetivas à abertura do capital social a não familiares. Também, em relação a este último aspeto, são sobretudo as empresas com menos de cinco anos que se apresentam mais abertas (37,5\%) (Gráfico 77). Uma das explicações poderá advir ainda da fase de crescimento do negócio e da necessidade de projetarem vários cenários para a sua continuidade. As que já estão há mais décadas em funcionamento revelam, a este nível, uma tendência para não abrir "mão" do seu negócio a membros não familiares.

\section{GRÁFICO 75. Expetativas de a empresa vir a realizar} uma mudança na estrutura acionista (sucessão da propriedade), nos próximos 3 a 5 anos

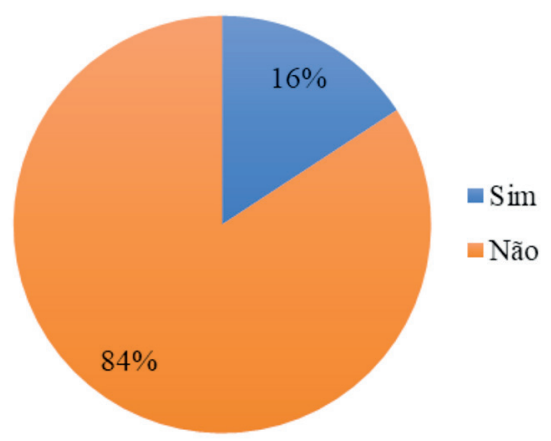

Fonte: Questionário EFs. 


\section{GRÁFICO 76. Principal mudança na estrutura acionista \\ (sucessão da propriedade), por dimensão}

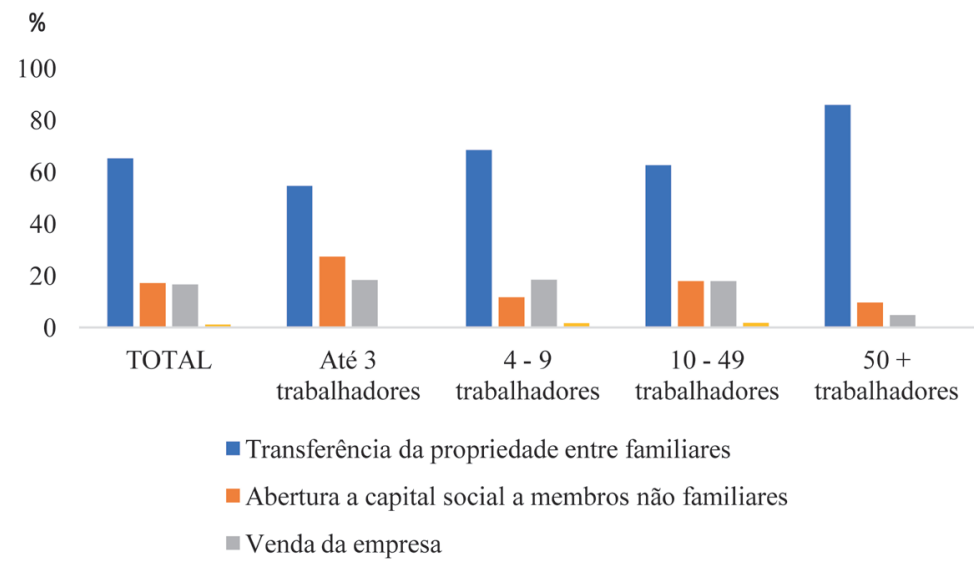

Fonte: Questionário EFs.

GRÁFICO 77. Principal mudança na estrutura acionista

(sucessão da propriedade), por antiguidade

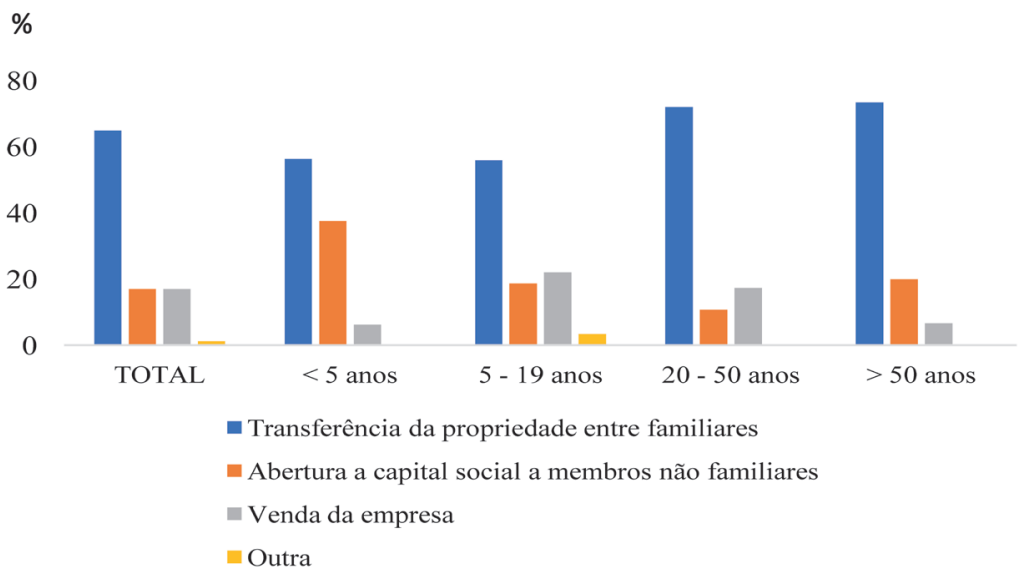

Fonte: Questionário EFs. 
O legado familiar e a forte ligação pessoal fundamentam o desejo de continuidade na transição do controlo executivo. A preferência na escolha do sucessor varia de família para família de acordo com tradições, orientação familiar, competência e preparação do sucessor, bem como de aspetos culturais e emocionais. Regra geral, nas empresas familiares determinadas a manter o seu controlo, a escolha da sucessão é limitada ao seio da família. Essa é uma informação corroborada pelos dados da nossa amostra em que, para a generalidade das empresas familiares, o sucessor da liderança da empresa deve ser procurado no seio da família (74,3\%). Admitindo que o sucessor da liderança seja procurado fora da família, repartem-se as opiniões entre procurar fora $(10,2 \%)$ ou dentro $(8,9 \%)$ do atual quadro de colaboradores/trabalhadores.

O êxito da sucessão pode potenciar o crescimento competitivo da empresa familiar uma vez que se perpetua o conhecimento idiossincrático nos membros da família. Este conhecimento interno permite a criação e exploração de recursos específicos da empresa familiar e sustentam a vantagem competitiva da empresa.

Ora, o processo de sucessão é em si complexo e engloba vários passos, entre eles, a preparação do sucessor para o seu papel de líder, a integração do sucessor (formato e momento da sua entrada) e, finalmente, a transferência de poder para o sucessor. A fase de incubação inicia-se quando o sucessor contacta com a empresa durante o seu crescimento. É comum nas empresas familiares existir proximidade, desde muito pequeno, do sucessor com o contexto familiar empresarial, o que facilita a aquisição de conhecimento tácito durante todo o processo de sucessão. Em encontros familiares, promove-se o espírito de empreendedorismo familiar e gera-se maior curiosidade no sucessor pelo desafio da empresa familiar.
As empresas familiares distinguem-se também pelas atitudes dos gestores-proprietários relativamente ao negócio, sendo que alguns preferem um maior envolvimento da família no seio da empresa. É habitual o processo de socialização na empresa das gerações mais novas começar muito cedo, sob a orientação e coordenação do fundador, de modo a potenciar o processo de sucessão.

Todavia, nem sempre o fundador se prepara para a sucessão e respetivo "desligamento" da empresa. Muitas vezes, a sucessão é adiada indefinidamente e desvalorizada devido à forte ligação entre o fundador e a empresa, fazendo com que a saída da empresa e a morte sejam encaradas como a mesma situação. Consequentemente, a reflexão sobre a sucessão exige que o fundador aceite a sua mortalidade, sendo essa uma tarefa árdua. Além disso, a importância que o fundador atribui à empresa vai mais além do que meramente resultados financeiros, englobando aspetos intangíveis, tais como o status, a sua imagem e poder, que o fundador teme tanto perder após deixar a sua posição. Esta postura explica porque muitos dos sucessores nas empresas familiares assumem a liderança perante motivos inesperados e não fruto de um processo planeado.

O estudo da Russell Reynolds Associates (2014), já referenciado, obteve, como resposta média dos quatro países participantes, qual deveria ser o tempo necessário para preparar o CEO da empresa: menos de 1 anos 40\%, 1 a 2 anos 33\% e mais de 2 anos $27 \%$. Dada a importância e o tempo necessário é relevante que os atuais líderes da empresa definam um planeamento que considere uma seleção de potenciais candidatos, a sua preparação, a seleção de um (ou mais se for para um conselho de administração), a sua nomeação e depois a efetiva passagem do testemunho. 


\subsubsection{Fatores de sucesso (e críticos) da empresa familiar}

As empresas familiares foram desafiadas a referir a importância que um conjunto de indicadores poderia ter para o sucesso das suas empresas (Gráfico 78). Foram selecionados 10 indicadores, aos quais deveria ser atribuída a respetiva importância numa escala de 1 = Nada importante até 5 = Extramente importante (passando por 2 = Pouco importante, 3 = Importante e 4 = Muito importante).

Em termos médios, sete dos indicadores registam níveis de importância em torno da categoria muito Importante (valor 4), destacando-se entre estes a preparação e treino do sucessor antes do efetivo início de funções $(4,13)$, a separação entre os interesses da família e os do negócio $(4,10)$ - dois fatores exclusivos das empresas familiares - e a existência de um planeamento estratégico a médio e longo prazo $(4,06)$ - fator comum a qualquer sociedade. Em contrapartida, os aspetos menos importantes apontados pelas empresas familiares, abaixo da simples importância (valor 3), aparece como pouco importante a abertura de capital social a membros familiares $(1,99)$ e ter gestores profissionais externos na direção da empresa $(2,67)$. Embora com níveis de importância ligeiramente diferentes em alguns dos aspetos, estes não são distintivos para as empresas de diferentes dimensões.

Avaliando a efetiva importância dos 10 indicadores, em termos de frequências, tomando

GRÁFICO 78. Nível de importância (valor médio) dos aspetos para o sucesso da empresa familiar.

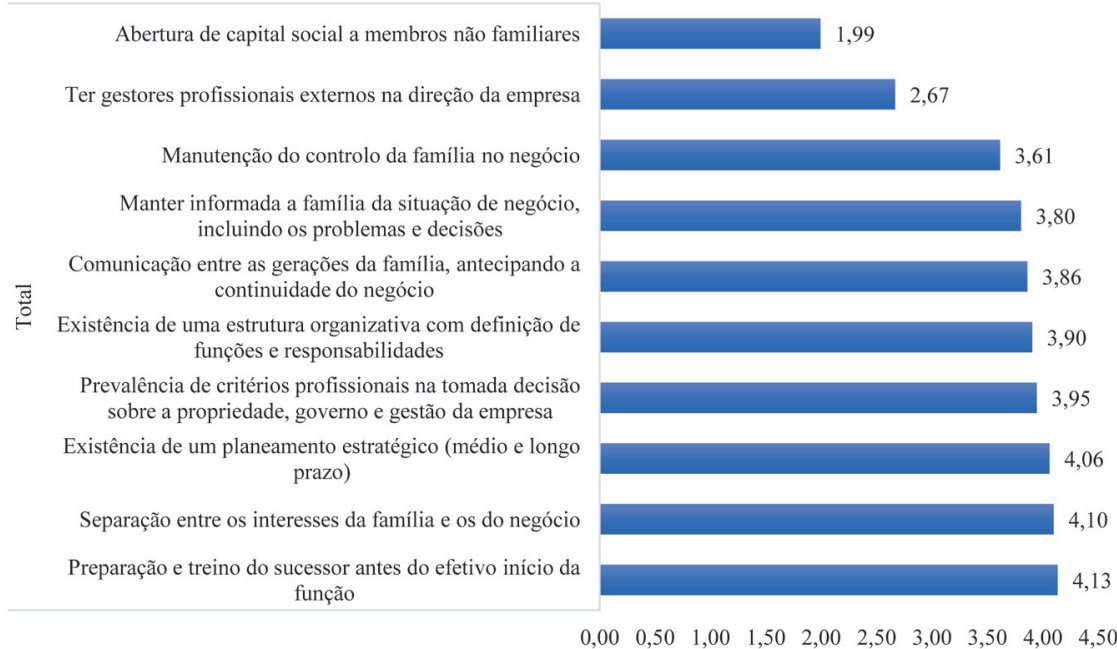

Fonte: Questionário EFs. 
em consideração as categorias que expressam importância (ou seja 3 = Importante, 4 = Muito importante e 5 = Extramente importante) e as sem importância (ou seja 1 = Nada importante e 2 = Pouco Importante), para além da categoria "Sem opinião", observam-se algumas alterações na ordenação dos aspetos sinalizados para o sucesso das empresas familiares. Diferenciando esta análise por dimensão da empresa, os resultados são muito similares, o mesmo se passando tendo em conta a sua antiguidade.

Claramente as percentagens são significativas para todos os itens à exceção da abertura de capital social a membros familiares (20\%) e da existência de gestores profissionais externos na direção da empresa (41,6\%), que assumem percentagens mais significativas quanto à sua menor valorização pelos respondentes (Gráfico 79).

De forma esquemática, evidenciam-se três fatores que mais contribuem, em termos relativos, para o sucesso de uma empresa familiar, configurando o nosso "TOP 3+ SUCESSO" (Figura 16). Estes são: TOP $1+$ Separação dos interesses da família e os do negócios; TOP 2+ Existência de um planeamento estratégico a médio e longo prazo; e TOP 3+ Preparaçãoe treino do sucessor antes do início efetivo de funções.

É certo que os seguintes aspetos também assume importância relevante, designadamente: i) manter informada a família da situação de negócio,

\section{GRÁFICO 79. Aspetos com e sem importância para o sucesso das EFs}

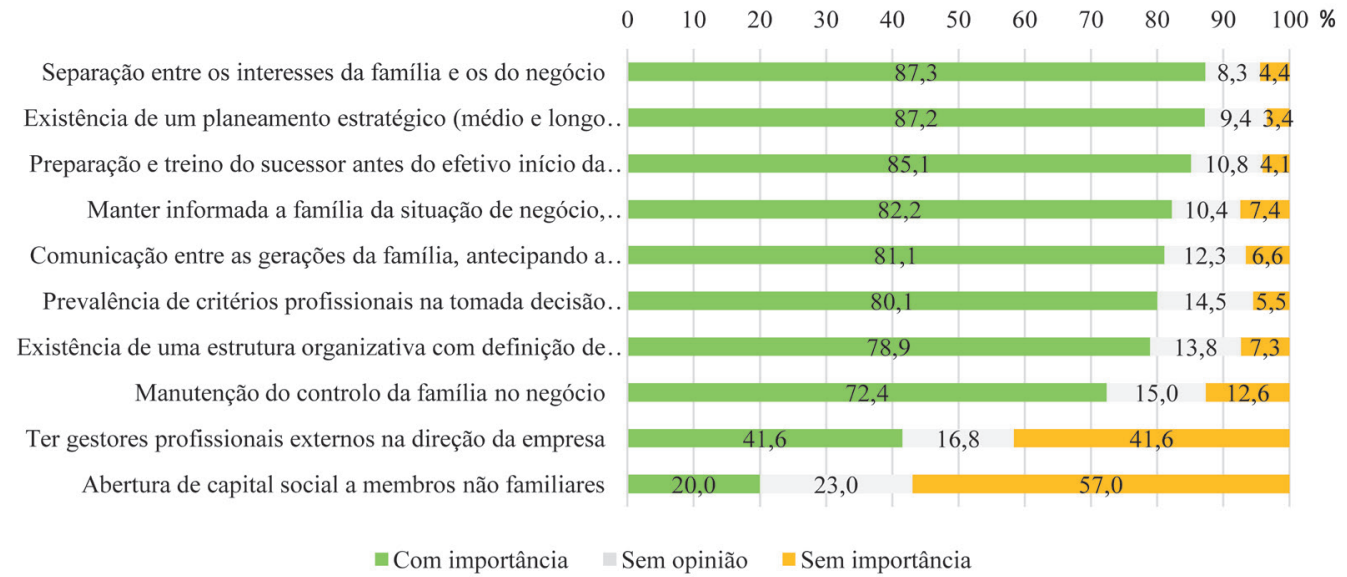

Fonte: Questionário EFs. 
incluindo os problemas e decisões; ii) comunicação entre as gerações da família, antecipando a continuidade do negócio; iii) prevalência de critérios profissionais na tomada decisão sobre a propriedade, governo e gestão da empresa; iv) Existência de uma estrutura organizativa com definição de funções e responsabilidades. Todos estes itens reforçam a importância daqueles três supra referidos.

\section{FIGURA 16. TOP 3+ Sucesso das EFs}

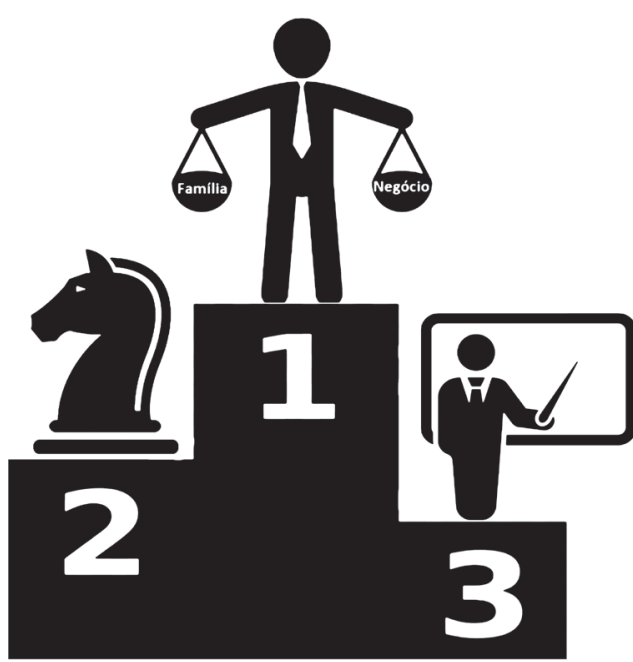

Para a sustentabilidade e profissionalização das empresas familiares importa assegurar a separação entre os interesses da família e os do negócio. Tal implica desenvolver uma estrutura de governance que permita organizar processos e procedimentos que estão na base da tomada de decisão, incluindo a preparação do sucessor. Tal pressupõe a adoção de estratégias de gestão e liderança mais objetivas e rigorosas, que sejam menos propensas à influência de fatores emocionais e, sobretudo, de laços afetivos e familiares.
Quando se confundem os papéis de proprietário, gestor, trabalhador e familiar, como referido atrás, as alianças estratégicas deixam de ser possíveis, dando lugar a polos de conflitualidade e frustração de expectativas a partir dos diversos posicionamentos na interação entre propriedade, negócio e família.

No sentido de promover uma boa governance das empresas familiares, destaque-se o papel específico quer da Constituição Familiar, quer das Instituições Familiares. A Constituição Familiar também referida como Plano Estratégico Familiar ou Protocolo Familiar é, numa forma mais visível e pragmática, uma declaração de princípios que rege os relacionamentos entre família, gestão e propriedade da empresa, com o objetivo de assegurar a continuidade intergeracional na gestão e controlo da empresa e, numa vertente mais abrangente e realista, o Protocolo Familiar é um processo de obtenção de um acordo consensual entre os membros da família empresária, do qual um dos outputs é um documento. Só por si, o Protocolo Familiar é um código de conduta sem imposição legal e sem uma estrutura formal e uniforme; contudo, uma grande parte das vontades alcançadas pode ser alvo de vinculatividade via recurso a instrumentos jurídicos como o pacto social, acordos parassociais, testamentos, doações e regulamentos ou procedimentos internos à empresa (Costa, 2017). Independentemente do reflexo jurídico, surgem também elementos cruciais do relacionamento empresa/família, que fazem parte deste código de conduta, tais como: valores e missão da família, regras de separação entre a riqueza da família e da empresa, regras para recrutamento, promoções e pagamento dos membros da família, código de ética, mecanismos de resolução de conflitos, entre outros. 
Por sua vez, as Instituições Familiares promovem também a manutenção da harmonia familiar e a continuidade da empresa. Dependendo da dimensão, da complexidade do negócio e do estágio da vida da empresa, a empresa familiar possui instituições como a Assembleia Familiar e o Conselho de Família. Na Assembleia Familiar discutem-se assuntos de índole familiar e empresarial. No início da empresa familiar, estas reuniões são encontros informais onde o fundador apresenta a sua estratégia e reúne propostas para novos investimentos. Com o crescimento da empresa, esta assembleia torna-se um fórum de discussão formal de questões relacionadas com valores da família e da empresa, recrutamento familiar e sua remuneração, entre outras. Esta assembleia é liderada por elemento sénior da família que também faz parte das reuniões executivas da empresa. O Conselho de Família é eleito pela Assembleia Familiar e tem um poder executivo na deliberação sobre assuntos familiares da empresa familiar.

É cada vez mais evidente que o processo de decisão nas empresas familiares é influenciado pela visão empresarial da família. Dada a sua singularidade, estas empresas procuram alcançar, para além de objetivos económicos, objetivos não-económicos que consequentemente condicionam a sua estratégia e os seus resultados. Estes objetivos não económicos estão próximos da dimensão da família e consistem em promover empregos para os membros da família e garantir a estabilidade do seio familiar. Assim sendo, as decisões das empresas familiares são muitas vezes caracterizadas por fatores emocionais, quando a empresa familiar sobrepõe os interesses da família aos interesses empresariais.

Poder-se-á sinalizar, igualmente em termos relativos, dois principais fatores críticos do sucesso da empresa familiar que se prendem fundamentalmente com: 1) Abertura de capital social a membros não familiares; 2) e Ter gestores profissionais externos na direção da empresa. A Manutenção do controlo da família no negócio, ainda que apresente uma proporção maioritária que assinala a sua importância para o sucesso da empresa familiar, regista um valor manifestamente inferior face aos outros itens escolhidos pelos respondentes da nossa amostra (Figura 17).

FIGURA 17. Reserva da EF a membros não familiares

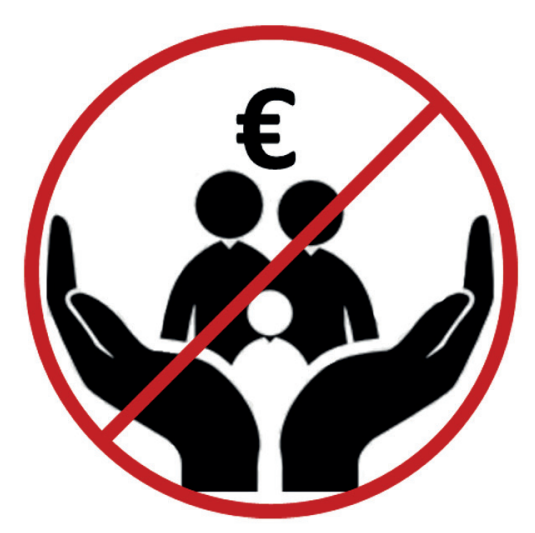

Fica patente a posição de reserva e fechamento da empresa quanto à possibilidade de entrada de membros não familiares na estrutura de propriedade e governo, bem como o desejo de manter o controlo da família no negócio. Apesar de nas empresas familiares, regra geral, a gestão e o controlo da empresa se confundam, é essencial esclarecer que a empresa familiar poderá continuar no seio da família, mas não sendo o poder executivo atribuído a nenhum membro da família. De facto, esta é uma das vias para que estas se possam profissionalizar, através do recrutamento de competências externas à família. 
É amplamente discutida a necessidade de distinguir entre a faceta de acionista e de gestor. Para as empresas familiares isto pode representar um grande desafio, uma vez que a família está habituada a ter o controlo total da estratégia da empresa e o dia-a-dia das operações e irá, agora, necessitar de aprender a ter uma atitude menos interventiva.

Contudo, cada vez mais empresas familiares começam a escolher este caminho de modo a assegurar a sua continuidade e conseguir manter o legado para as gerações vindouras através da propriedade e não da gestão. A sucessão da propriedade pode representar alterações na estrutura acionista (com mudanças da propriedade entre familiares e entre não familiares). Por isso, é essencial que as empresas desenvolvam processos de profissionalização para serem bem-sucedidas. Para além do recrutamento externo de competências, o estabelecimento de estruturas de governance bem definidas assume um lugar estratégico na sustentabilidade das empresas familiares.

\subsection{Desafios e vulnerabilidades das EFs}

Apesar de se ter sinalizado atrás a existência de empresas familiares com estratégias de crescimento, diversificação, internacionalização e inovação, estas enfrentam uma conjuntura altamente competitiva no contexto da globalização dos mercados. Tal caracteriza-se pela mudança constante quer nos modelos de gestão, quer nos gostos e preferências dos clientes, associado a maiores exigências ao nível da qualidade e rigor nos processos de produção. Com efeito, o mundo empresarial está cada vez mais concorrencial, o que aliado aos riscos políticos emergentes (e.g. Catalunha, Brexit) tem criado pressão sobre as empresas.
Neste contexto, as empresas familiares necessitam de planeamento estratégico. Precisam de estar atentas às alterações do mercado no sentido de conseguirem adaptar e adequar a sua oferta de produtos e serviços para melhor satisfazerem os consumidores. Ou seja, precisam de perceber as macrotendências de forma abrangente, desde alterações dos gostos e preferências até ao impacto dos avanços tecnológicos, para que possam oferecer um leque de serviços com valor acrescentado e diferenciador.

A intensidade concorrencial tem-se traduzido numa maior pressão sobre os preços que, aliado à subida dos custos de produção (por exemplo, custo de energia, subida do salário mínimo, etc.), conduziu a pressões ao nível da rentabilidade das empresas. Do balanço dos pontos fortes e principais preocupações, os nossos resultados apontam claramente para os principais aspetos já sinalizados neste relatório.

Quanto aos principais pontos fortes das empresas familiares, os respondentes foram desafiados a procederem a uma comparação com os respetivos concorrentes, selecionando um máximo de 5 possibilidades entre 13 disponíveis. Da leitura do Gráfico 80 todas as empresas mencionaram como principal ponto forte a valorização do atendimento ao cliente (72,7\%). Imediatamente a seguir, globalmente, foram considerados outros pontos fortes, como: preços competitivos (54,3\%), diversidade de produtos (47,6\%), decisões rápidas e de forma flexível (44,0\%), marca forte ou presença no mercado $(39,8 \%)$ e capacitação profissional dos trabalhadores (32,2\%).

Em contrapartida, os indicadores menos apontados como pontos fortes foram: a ligação a centros de I\&D tecnológicos e de conhecimento (3\%), marketing com impacto junto dos mercados (6,4\%), atração e fixação de trabalhadores com 
GRÁFICO 80. Principais pontos fortes das EFs. em relação aos concorrentes

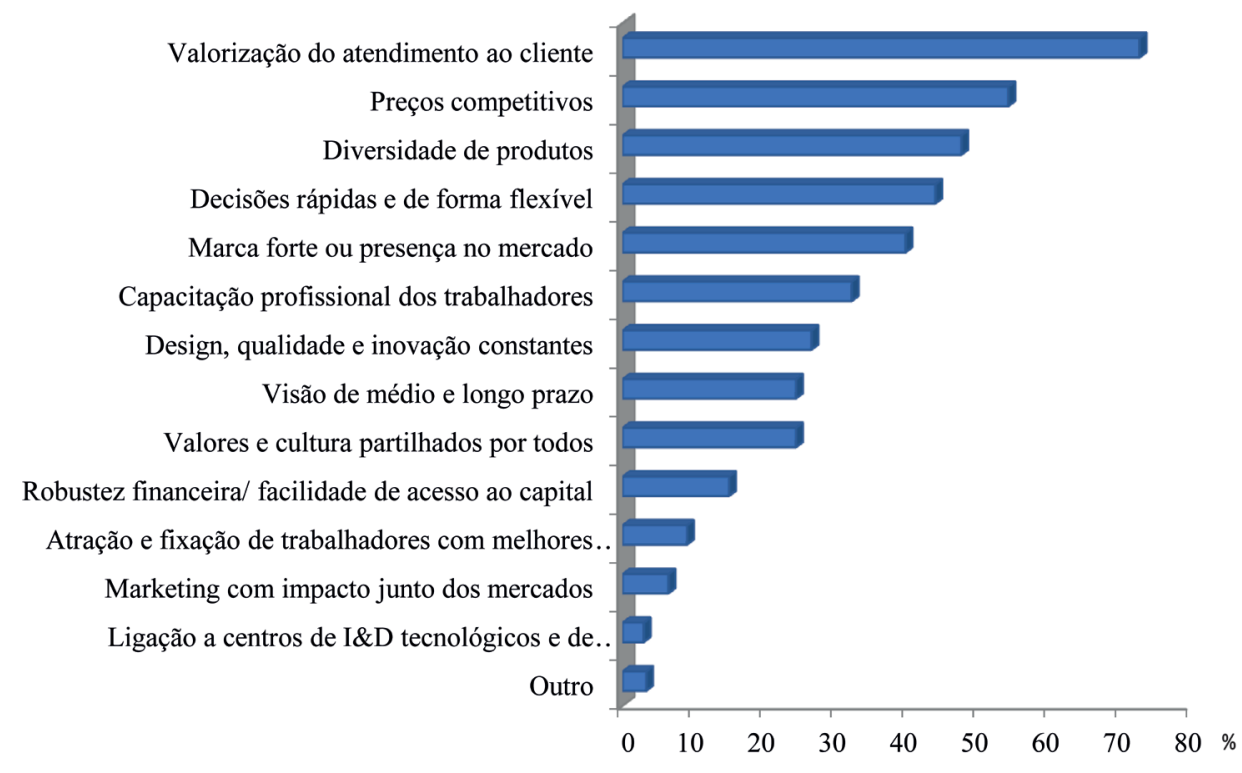

Fonte: Questionário EFs.

melhores competências $(9,1 \%)$ e robustez financeira ou facilidade de acesso ao capital (15\%).

Em relação aos indicadores apontados, e considerando sobretudo a dimensão da empresa importa acrescentar as variações observadas no Gráfico 81. Nas micro empresas, as decisões rápidas e de forma flexível $(47,1 \%)$ são apontadas como ponto forte antes da diversidade de produtos (43,8\%), nas pequenas empresas, a marca forte ou presença no mercado $(52,6 \%)$ evidencia-se como o segundo ponto forte, e, nas maiores empresas, a marca forte ou presença no mercado $(60,6 \%) \mathrm{ul}-$ trapassa a valorização do atendimento ao cliente (58,7\%), passando também o design, qualidade e inovação constantes (46,5\%) para terceiro ponto forte, na comparação com os concorrentes. Por sua vez, nas maiores empresas, a robustez financeira ou facilidade de acesso ao capital (29,7\%) assume importância como ponto forte.

Em seguida, as empresas familiares foram desafiadas a procederem a uma comparação com os respetivos concorrentes quanto às principais preocupações com a empresa, selecionando um máximo de 5 possibilidades entre 14 disponíveis (Gráfico 82). À cabeça das principais preocupações com a empresa familiar é referido o peso da carga tributária $(60,6 \%)$, seguindo-se a incerteza do ambiente económico e financeiro $(53,4 \%)$, a retração das vendas (45,4\%) e a redução do lucro (40,6\%).

No polo oposto, entre os aspetos não identificados como principais preocupações, na 


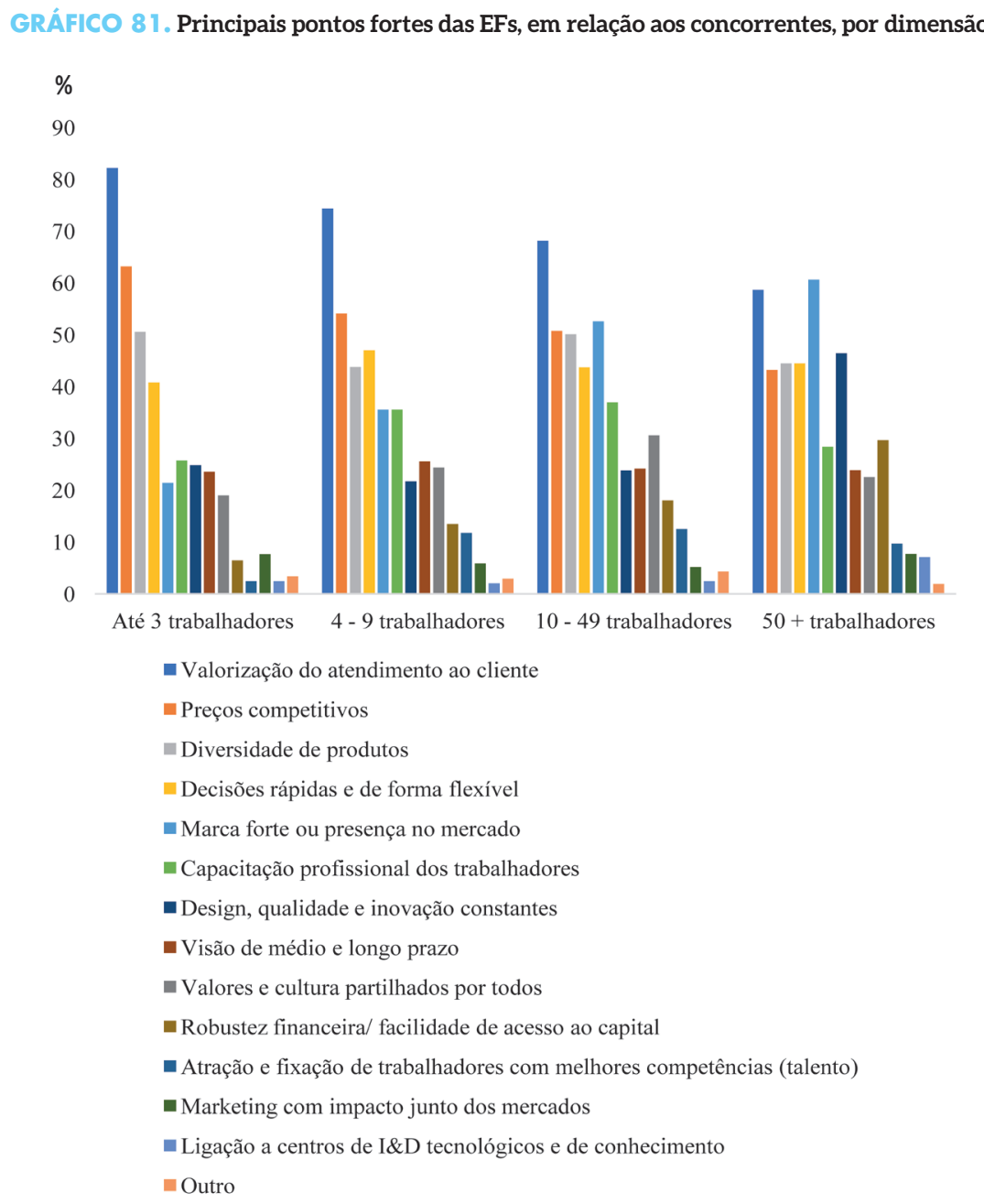

Fonte: Questionário EFs.

comparação com os concorrentes, aparece a transferência da propriedade para um ou mais membros da próxima geração $(6,4 \%)$, a gestão de familiares na empresa (8,1\%), a gestão de conflitos (8,3\%) e a profissionalização da gestão da empresa (9,5\%). Ora, tais preocupações assumem particular relevância dado que representam elementos considerados incluídos nos principais fatores que levam ao desaparecimento das empresas familiares. 


\section{GRÁFICO 82. Principais preocupações das EFs, em relação aos concorrentes}

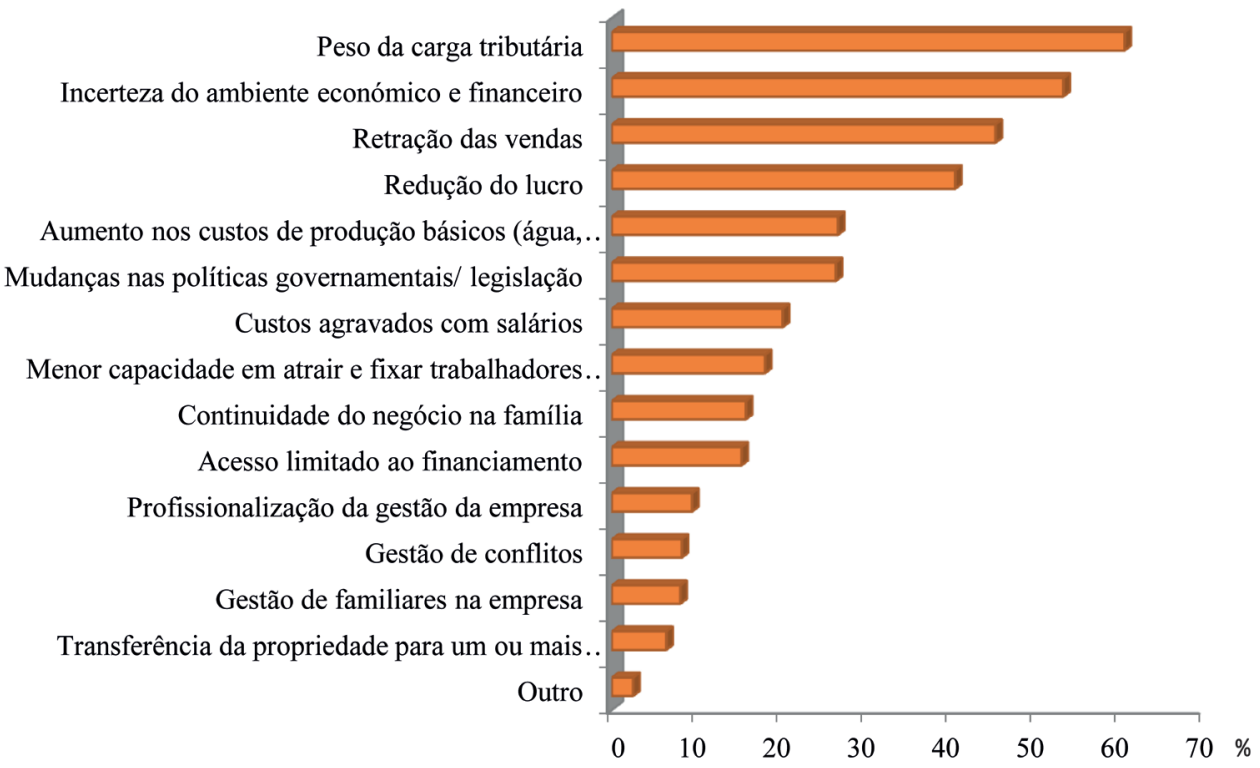

Fonte: Questionário EFs.

Analisando as diferenças entre as preocupações com a empresa familiar, em função da dimensão da empresa, confirma-se que as quatro principais preocupações são as mesmas, quer se trate de micro empresas ou pequenas empresas, o mesmo acontecendo com os aspetos não referenciados como principais preocupações. Já no caso das maiores empresas, a principal preocupação é a incerteza do ambiente económico e financeiro (52,9\%) em detrimento do peso da carga tributária $(49,0 \%)$, adquirindo ainda alguma relevância a preocupação com os custos agravados com salários (34,8\%) (Gráfico 83). 


\section{GRÁFICO 83. Principais preocupações das EFs em relação aos concorrentes, por dimensão}

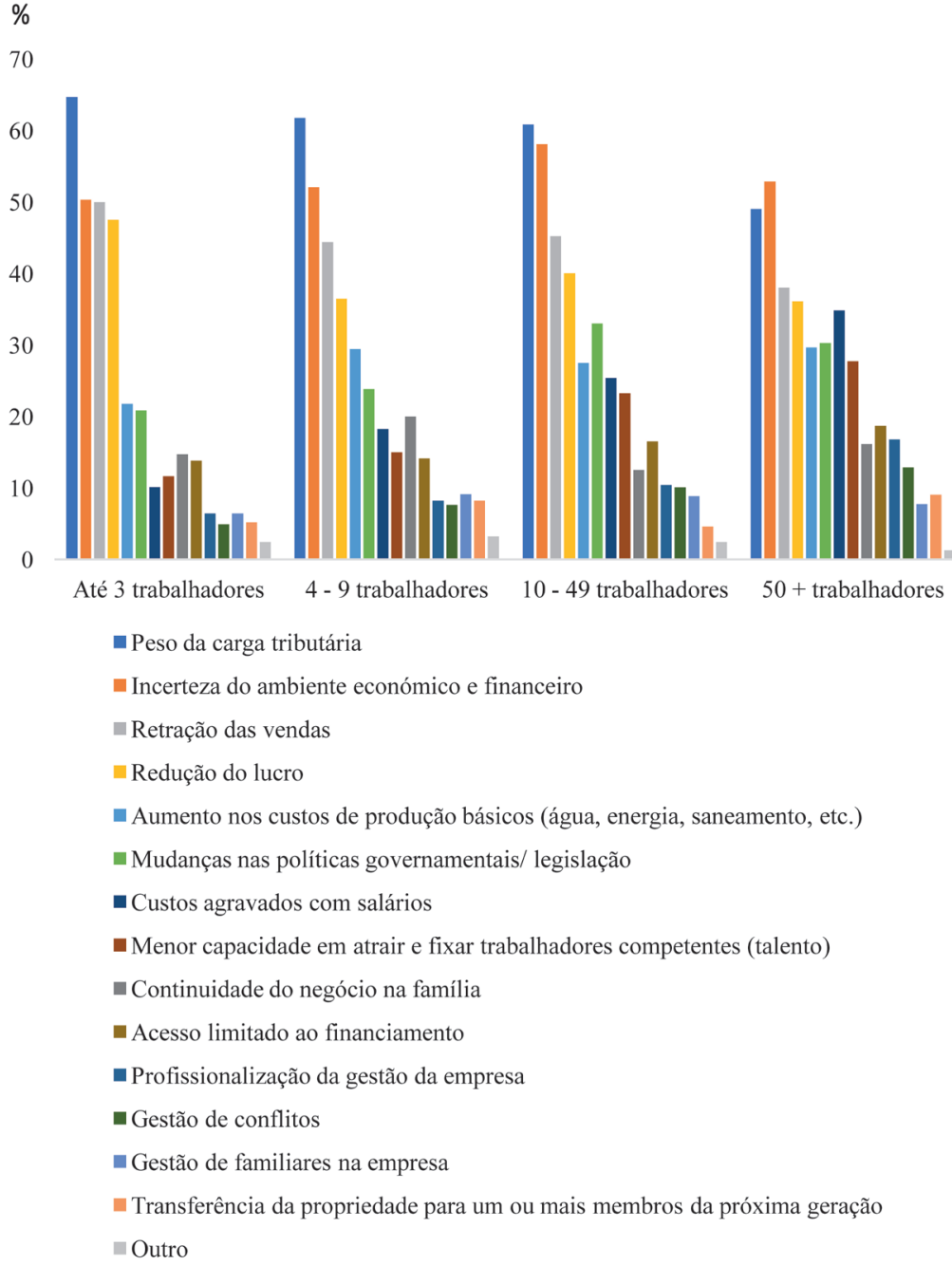

4 - 9 trabalhadores

10 - 49 trabalhadores

$50+$ trabalhadores

- Peso da carga tributária

- Incerteza do ambiente económico e financeiro

- Retração das vendas

- Redução do lucro

- Aumento nos custos de produção básicos (água, energia, saneamento, etc.)

- Mudanças nas políticas governamentais/ legislação

- Custos agravados com salários

- Menor capacidade em atrair e fixar trabalhadores competentes (talento)

- Continuidade do negócio na família

- Acesso limitado ao financiamento

- Profissionalização da gestão da empresa

- Gestão de conflitos

- Gestão de familiares na empresa

- Transferência da propriedade para um ou mais membros da próxima geração

- Outro

Fonte: Questionário EFs. 


\section{Testemunhos e singularidades de empresário(a)s}

Em primeira pessoa, apresenta-se um conjunto de testemunhos de empresário(a)s de empresas familiares que aceitaram partilhar memórias, experiências e projetos empresariais e sua relação com a família. A autoapresentação, a partir de palavras-chave mais relevantes, permitem, ainda que de forma breve, conferir "rostos" às empresas familiares, salvaguardando-se o anonimato e a confidencialidade da informação recolhida. A esta escolha presidiu a intencionalidade de se aprofundar alguns dos aspetos mais relevantes destacados neste estudo por via do mapeamento e dos retratos traçados das empresas familiares da região Norte.

\subsection{O "rosto" das EFs}

Das 23 entrevistas realizadas, são relevantes as seguintes palavras-chave para a autoapresentação de cada um do(a)s entrevistado(a)s, em resultado do tratamento do conteúdo dos seus discursos (Figura 18).

FIGURA 18. Palavras-chave de autoapresentação do(a)s entrevistado(a)s

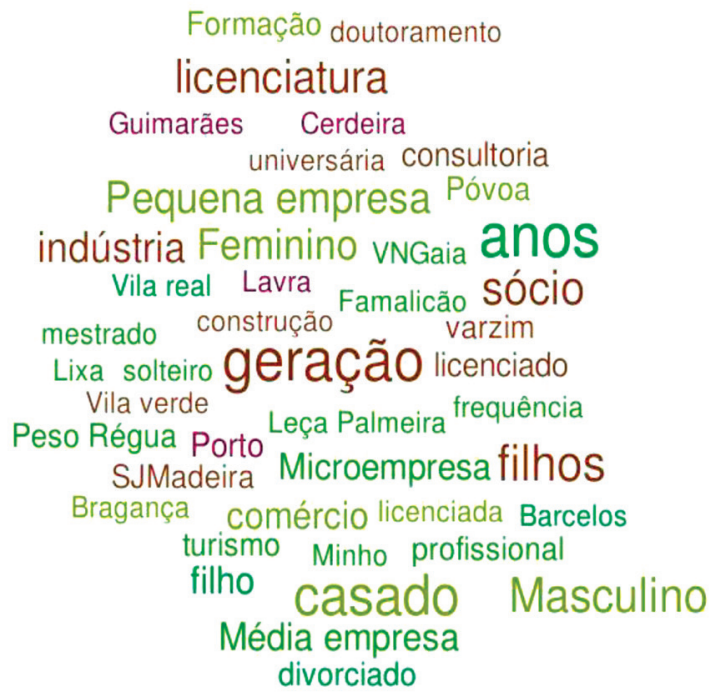

Fonte: Entrevistas a Empresário(a)s 
São visíveis termos mais expressivos como "geração", "casado", "masculino", "feminino", "anos", "licenciatura" e "pequena empresa". Estes conferem robustez ao retrato já apresentado do perfil das empresas familiares que responderam ao questionário. Remetem-nos, também, para localizações geográficas no âmbito das NUTS III da região Norte, estando presente áreas diversificadas de negócio desde a indústria ao comércio, consultoria científica-técnica, turismo e construção.

Dos 23 entrevistado(a)s, dois terços são do sexo masculino, têm idades compreendidas entre os 30 e os 60 anos (mais expressivo o intervalo etário dos 40 aos 50 anos), e a esmagadora maioria detém o ensino superior (licenciatura, incluindo mestrado e doutoramento). São empresário(a)s fundadores(as) ou de $2^{\text {a }}$ geração, ainda que alguns sejam já de $3^{\mathrm{a}}$ ou mais gerações, que assumem predominantemente o estatuto de sócio gerente ou CEO e estão à frente dos destinos da empresa tendencialmente há mais de 20 anos. Acresce a esta informação, o estatuto civil e a importância do agregado familiar. Quase todos são casados, com o registo de situações de divórcio ou estatuto de solteiro. $O$ agregado familiar tende a ser constituído sobretudo por dois a três elementos, o que nos remete para a importância do cônjuge e de filhos na dinâmica da relação da família com a empresa.

\subsection{Passado, presente e futuro das EFs}

Articulado a um registo biográfico da empresa, expõe-se analiticamente os seguintes eixos temporais: 1) o passado da EF: história do(a) fundador(a), processo de sucessão, razões de criação e principais meios de financiamento, principais momentos/ alterações que a empresa enfrentou; 2) o presente: modelo de governação da empresa, estratégias para a manutenção da empresa familiar nas "mãos" da família, profissionalização da gestão e dos recursos humanos, investimento em inovação e estabelecimento de parcerias de I\&D e a preparação (caso tal se aplique) da sucessão da liderança, gestão/ propriedade; 3) o futuro: balanço e mudanças da empresa projetadas para 3 a 5 anos, posição face à desmaterialização e investimento em formação específica para futuros trabalhadores e o desenho de principais políticas que permitam conferir visibilidade/ alavancar a atividade desta tipologia empresarial ${ }^{39}$.

Em termos globais, as palavras mais frequentes que emergem do discurso foram, em grande destaque, "empresa", seguida por "pessoas, "família" e "trabalho. Fica bem patente a relação de interdependência entre o trabalho e a família, por um lado, e a importância das relações estabelecidas com pessoas da família e não família.

O recorte e a seleção dos temas mais frequentes, por sua vez, remetem para maior destaque atribuído ao eixo de profissionalização e inovação (30\% dos excertos codificados), à história da empresa (19\% das codificações), ao perfil do gestor e à governação da empresa $(15 \text { e } 14 \%)^{40}$. A sucessão da empresa, as questões de género e as perspetivas de futuro são os temas com menor peso nas codificações (valores abaixo dos $9 \%)^{41}$.

\footnotetext{
39 Muitos destes temas já foram abordados nas secções precedentes deste relatório, pelo que não serão alvo de aprofundamento específico nesta seção.

40 A partir da matriz concetual, a análise englobou um total de 2440 codificações dos 23 documentos.

41 1 A conceção do guião foi orientada para a os diferentes perfis de entrevistado(a)s, contendo diversas temáticas que não serão objeto de tratamento do presente relatório.
} 


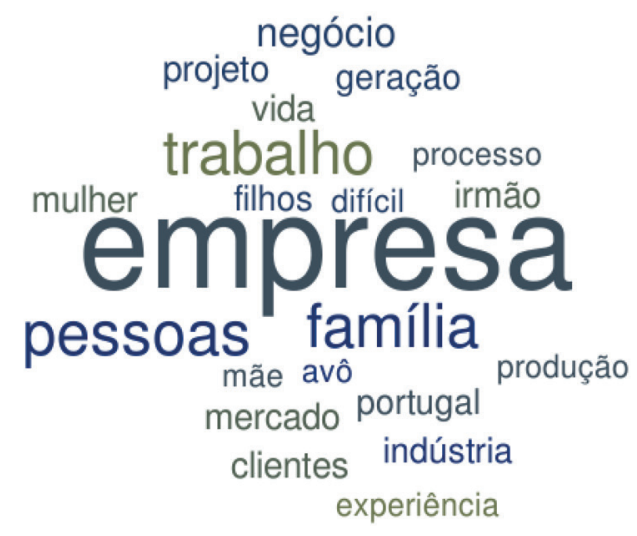

Fonte: Entrevistas a Empresário(a)s.

Aprofundando a informação recolhida, pode-se identificar os temas que mereceram maior destaque na análise das 23 entrevistas. Dentro do tema "profissionalização e inovação", refiram-se os exemplos de internacionalização e inovação; competências dos colaboradores mais valorizados pelos gestores; a evolução dos recursos humanos e as condições de trabalho; e políticas públicas. Sobre a "história da empresa", os temas com maior preponderância remetem para o próprio fundador e as várias atividades que a empresa desempenha ou desempenhou. No que respeita ao "perfil do gestor", é de salientar as dimensões associadas à sua formação académica e profissional e à primazia da herança familiar. O tema "governação da empresa" é discutido, sobretudo, ao nível das questões associadas ao próprio modelo de governação e processos de tomada de decisão. As "perspetivas de futuro" remetem para a projeção entre 3 a 5 anos da própria empresa e as respetivas mudanças que se antecipam concretizar. As "questões de género" focam, particularmente, as potencialidades associadas ao sexo feminino e suas competências diferenciadas em comparação com o sexo masculino. Por fim, a "sucessão na empresa" é discutida, principalmente, numa lógica de manutenção da empresa na família e os próprios mecanismos que a possibilitam. Cada um destes temas per si permite desenvolvimentos aprofundados sobre desafios e dilemas específicos às empresas familiares na atualidade, em linha com o que acontece internacionalmente.

Nesta secção destacaremos algumas posições singulares e discursos que sustentam os aspetos mais 
relevantes destacados neste estudo por via do mapeamento e dos retratos de empresas familiares. Mais uma vez, não se pretende ser exaustivo, mas tão só ilustrar dinâmicas em curso mais expressivas da vida das empresas familiares a partir dos objetivos do presente estudo.

\section{Internacionalização e inovação}

Referimos que o processo de internacionalização é encarado como um desafio difícil para as empresas familiares. A sua capacidade de internacionalização - em particular as de menor dimensão - pode ser limitada pela escassez dos recursos financeiros e de insuficiente know-how de gestão. Por sua vez, sabe-se que as atitudes e os comportamentos estão relacionados com as gerações à frente da empresa. As empresas familiares mais antigas, sobretudo as do setor da indústria, comandadas pela terceira (ou subsequente) geração, têm um maior interesse e empenho no processo de internacionalização, encontrando-se consolidadas no mercado global.

"Nós trabalhamos 95\% para fora, para exportação, só temos um cliente em Portugal, em Lisboa, uma cliente em Lisboa." (E13_F_3 ${ }^{a}$ Geração_Indústria)

"Em termos de quota do mercado, 70\% são estrangeiros, isto especialmente americanos, canadianos, franceses." (E4_M_1 ${ }^{\mathrm{a}}$ Geração_Turismo)

"Hoje há uma preocupação muito grande com a exportação, nós exportamos desde os anos 80 ; nós exportamos $95 \%$ do que nós fazemos, chegamos a exportar $97 \%$ do que fazemos." (E19_F_5a Geração_Indústria)
Já as gerações tendencialmente mais jovens podem ser facilitadoras deste processo de internacionalização pelas novas ideias e formas de ver e pensar o mundo, fruto em grande parte da experiência (muitas vezes mais cosmopolita) e preparação académica.

"Estamos a falar de exportar tecnologia de Portugal para fora para o setor vitivinícola e não sermos só nós a receber, mas a levar para

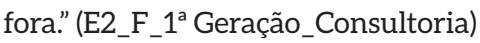

"Pesquisei muito antes de fazermos isto, visitei algumas cidades e alguns países à espera de ver. O google hoje diz tudo, eu não conheço, não há em lado nenhum do mundo uma coisa igual a esta, há situações similares em que realmente há restauração." (E22_M_3 ${ }^{\mathrm{a}}$ Geração_Comércio)

"Eu acho que é importante o nosso contributo porque nós tivemos outra visão que a minha mãe e os meus tios não tiveram e eu acho que nós podemos contribuir, não só por sermos licenciados (...), mas sim pela experiência que nós podemos ter trazido de outras empresas onde nós estivemos." (E13_F_3 $3^{a}$ Geração_Indústria)

No entanto, não existe uma uniformidade de posições. Muitas vezes as gerações mais novas que entram na empresa são mais orientadas para a conformidade dos valores já existentes e tendem a promover a continuidade, em detrimento da mudança estratégica necessária para a dinamização de um projeto de internacionalização. Ainda assim, fica patente em alguns dos discursos a intenção de desenvolver prospeção futura e de abertura para outros mercados em contexto nacional e, principalmente, internacional. 
"A nossa base é realmente o Norte e muito Guimarães e zona dos têxteis lar, depois temos alguma coisa Penafiel (...). Mas achamos que podemos trabalhar ainda mais em mercados diferenciados e temos feito aí uma consulta e há empresas que realmente fazem nichos de mercado muito interessantes e que nós podemos ser fornecedores e que nem compram em Portugal (...)." (E11_F_22a Geração_Indústria)

"A empresa foi crescendo, continuávamos a trabalhar no balcão, para encomendas ao balcão, mas também para armazenistas e distribuidores a nível nacional. Tínhamos alguns clientes na altura que nos compravam a produção daquilo que era feito. (...) Verificarmos que temos quase 100 anos de história e cada vez mais o consumidor procura junto das empresas as histórias das empresas." (E23_M_3 ${ }^{a}$ Geração_Comércio)

"No ano passado, abrimos uma loja, também foi uma decisão assim um bocado não pensada, que foi abrir uma loja própria. Os nossos clientes normais, na parte que é industrial, nós vendemos aos fabricantes ou móveis, ou carpintarias, ou serralharias, na parte decoração, tintas, mesmo que seja para o exterior, etc., nós normalmente vendemos ao retalho, para as lojas (...)." (E7_M_2a Geração_Indústria)

\section{Diferenciação, inovação e economia digital}

Na atualidade, a conjuntura económica apresenta-se altamente competitiva. Importa que as empresas familiares sejam capazes de acompanhar a mudança constante quer nas preferências e gostos dos clientes, quer na gestão e produção. As maiores exigências de qualidade e rigor nos processos de produção são cruciais na sustentabilidade das empresas, mas também na capacidade de estas se assumirem pela diferença em termos de criação de um nicho de mercado.

O desafio da maior exposição das empresas familiares à economia digital (KMG, 2017; UE, 2009) parece encontrar aqui já um terreno de prática e exemplo. Com efeito, alguns discursos reforçam o facto de terem aderido à economia digital no contexto da designada Rev. 4.0, retirando daí as vantagens que lhe são associadas não só em termos de marketing digital e vendas online, por exemplo, como mesmo ao nível dos processos produtivos. Outros testemunhos recolhidos reiteram a não "substituibilidade" da interação humana, do nome e da reputação das empresas familiares, apesar da difusão das TIC.

"O luxo tem que ser exclusivo! (...) tem de haver produtos de luxo que são luxo para toda a gente, (porque) ninguém gosta de usar uma joia e sair à rua e toda a gente usar uma joia semelhante. (...) A informação que partilhamos para o público não é informação técnica, é informação que as pessoas gostam de ouvir, as histórias, o enquadramento, ir buscar a história das princesas e dos reis e das coroas é isso que nos faz sonhar! Nós temos que pôr as pessoas a sonhar!" (E23_M_3 ${ }^{a}$ Geração_Comércio)

"Agora o que nós fazemos em termos digital... em indústria 4.0 - não estou a falar da parte das vendas online - notamos que hoje em dia houve uma evolução muito grande em termos de máquinas e indústria. Vendemos, por exemplo, robots para a indústria têxtil, que fazem aquelas toalhas ou panos de cozinha, em que os próprios robots já cortam o pano, já fazem a costura, põem as etiquetas e esses robots substituem umas 30-40 costureiras. 
(...) Mas a nível de fábrica e a nível de indústria houve uma evolução tão rápida como a do nível digital (...) hoje em dia ...substitui-se a mão-de -obra por máquinas." (E17_M_3 ${ }^{a}$ Geração_Comércio)

"Esta tal indústria 4.0 em que as coisas comunicam umas com as outras, de certa forma há mecanismos que nós já temos! Claro que nos preocupa e podemos tirar mais-valias com isso, mas também vai exigir algum investimento da nossa parte para nós estarmos adaptados. Mas nós sempre fomos muito à frente... nós já tínhamos um sistema de gestão documental implementado na empresa, portanto falava-se das normas de 9001 e fomos dos primeiros a tê-la." (E3_F_3 ${ }^{a}$ Geração_Turismo)

"Porque esta história do imaterial e do digital percebe-se, mas eu acredito ainda muito no 'lado a lado' e eu acho que, se, por um lado, eu percebo o digital e temos de o respeitar, por outro, temos de trabalhar com uma coisa que eu acho que vai ter muito valor no futuro que é com o lado do contacto, o lado da relação humana, das relações que se criam (....)" (E2_F_1 ${ }^{a}$ Geração_Consultoria)

Os legados históricos familiares, a par das especificidades do setor económico, tendem a prevalecer na estratégia de inovação e dar corpo a todo um projeto que acompanha a evolução ao nível da diversificação e flexibilidade do processo de produtivo.

"Porquê temos vindo a ser inovadores? Bom, primeiro eu acho que a grande batalha desta empresa foi conseguir manter a porta aberta, isto foi a primeira, não lhe chamaria uma inovação mas uma resiliência muito grande, fomos sempre combatendo com os punhos cerrados e a boca e os dentes fechados para ter capacidade de luta! (...) Quem viaja e tem os olhos abertos e é suficientemente curioso para ver as coisas boas tende, de alguma forma, a imita-las e copia-las para nós, e o que é que eu comecei a ver, os modelos de gestão... determinadas matérias ... no nosso setor da fundição. O setor da fundição é um setor metalúrgico de base, muito tradicional, muito conservador, embora exista uma contradição já que somos maioritariamente todos exportadores: este setor exporta $75 \%$ do que faz e exporta para setores de ponta. Mas se formos a ver as fábricas, pelo menos as mais antigas, estamos a falar de tecnologias de 20, 30, 40 anos com poucos upgrades, ou com upgrades quase de correção! Somos um setor em que o investimento em capital é muito intensivo e a rotação do ativo é muito baixa, porque a atratividade de fazer investimentos nesse setor é muito baixa. (...) A fundição técnica onde nós estamos faz peças muito especiais ou muito técnicas, peças de muita responsabilidade. Primeiro, nós estamos no setor de energia nuclear, fazemos peças para a energia nuclear; estamos na indústria do ferro rodoviário em classe um, ou seja, peças da maior responsabilidade, travões, suspensões, motorização e engates; estamos na área das barragens; estamos na área da indústria alimentar, portanto, estamos numa área muito de técnica. (...) O nosso ADN é ser (...) flexível, não querendo fazer produto próprio, ... é sempre a partir de um caderno de encargos de alguém e perceber quais são as lacunas que a cadeia de valor possa ter ou aquele serviço que o cliente precisa que alguém faça e que é normalmente complementado pela nossa peça!" (E12_M_2a Geração_Indústria) 


\section{Autofinanciamento e controlo patrimonial}

É comum haver uma interligação tão forte entre o património pessoal dos proprietários e o da empresa, que um pode confundir-se com o outro. Este comportamento de colocar à disposição da empresa a sua riqueza pessoal e familiar justifica, muitas vezes, a maior aversão ao risco que as empresas familiares podem registar. Muitos testemunhos reforçam a importância do "capital familiar" no financiamento e controlo patrimonial. Desde as instalações da própria empresa, ao terreno em que se localiza, até às fases subsequentes de investimento de capital para fazer face às adversidades cíclicas do negócio, o autofinanciamento revela-se crucial na vida das empresas familiares.

"O facto de termos o terreno claro que facilitou imenso, ter um sítio para colocar a empresa é muito mais fácil do que ter de estar a comprar um terreno, fazer o investimento. Nós começamos do zero, o que herdamos foram terrenos, não herdamos valores monetários. (...) Nós sempre centramos a empresa numa perspetiva de crescimento e não de retirar dividendos da empresa para fins próprios. Todo o nosso investimento de vida é o património que temos atualmente." (E1_F_2 ${ }^{\mathrm{a}}$ Geração_Comércio)

"Os terrenos inicialmente eram da família, depois ele [tio] comprou este terreno, criou aqui um projeto, fez o projeto, desenvolveu isto tudo, construiu ele próprio a parte de desenvolvimento de terraplanagem com os empregados antigos e muitos dos empregados antigos que ainda hoje mantemos ajudaram a construir este edifício, esta fábrica com o apoio do meu pai e dos meus tios." (E12_M_2a Geração_Indústria)
"Há que investir os capitais próprios e neste momento, acho que faz sentido investir num edifício, investir em stock, investir em condições para que, no fundo, estas empresas que eu represento, terem elas também melhores condições para se fazerem representar em Portugal." (E2_F_1ª Geração_Consultoria)

O recurso à banca também constitui uma prática, ainda que seja em situações relativamente pontuais. Em geral, as empresas familiares são bem vistas, na perspetiva de quem concede empréstimos, dada a importância e o enfoque de longo prazo e continuidade da empresa. A visão da empresa familiar como legado para as próximas gerações, confere-lhes maior fiabilidade no cumprimento de (possíveis) endividamentos. E essa maior segurança na atribuição do crédito é cimentada pela relação estreita existente entre o património empresarial e a riqueza pessoal.

"Sim, na altura o financiamento foi mesmo bancário na altura e com um inconveniente ...de que na altura havia juros a 30\% e eu não fazia a mínima ideia do que era isso. Só comecei a sentir isso mais tarde, porque comecei a ver que a capacidade de nós vendermos, de termos lucros para pagar esse tipo de despesas não eram assim tão fácil (...) Depois, veio a aprendizagem de nunca estar com um único banco a trabalhar, haver, digamos, aqui um tratamento mais especial com uns, aqueles nos favorecem e com aqueles com quem nós trabalhamos mais, mas também não descuidar dos outros porque muitas vezes são esses mesmos que nos dão mais apoio (....)." (E10_M_1 ${ }^{a}$ Geração_Consultoria) 


\section{Visão e missão do(a) fundador(a): ○ "espírito empreendedor"}

Numa fase inicial da empresa familiar, o fundador tem uma posição única e privilegiada na criação da identidade cultural base da organização, impondo os seus valores e crenças. Estes são formados pela sua própria personalidade e história cultural, e daí que espelhe a educação do fundador, a sua infância, a sua experiência de vida, a sua família e os antecessores. Os testemunhos são muito diversos e de uma riqueza imensa que espelham a dimensão empreendedora, o risco e a ousadia do fundador no arranque e na manutenção da empresa familiar. Por sua vez, o papel do(a) fundador(a) no desenvolvimento local e comunitário assume relevância na história da empresa.

"Eu não, mas lembro-me, e marcou toda a família a forma de ser e estar dele [fundador], e digo isto porque há muita gente que tem uma simpatia, ainda hoje passado 18 anos! Toda a gente se lembra do $\left.{ }^{[* *}\right]$ e com nostalgia e com um prazer especial! (...) Conviver com ele no dia-a-dia, eu acho que é o que se pode dizer de um homem do antigo regime, com todos os prós e contras dessa altura." (E22_M_3 ${ }^{\mathrm{a}}$ Geração_Comércio)

"Os meus avós eram de uma aldeia [***], que é muito conhecida por ser também uma terra de negociantes. Portanto, os meus bisavôs ... já negociavam, tinham comércio aberto, entretanto, o meu avô e a minha avó casaram e não havia mais espaço na altura - estamos a falar em 1930 - , uma aldeia ou uma cidade ou uma vila, onde ainda não houvesse negócio estabelecido, porque havia uma regra em que em cada aldeia só poderia haver um comércio aberto naquele setor. Depois, o meu avô paterno faleceu cedo e o meu pai, sendo o mais novo de 7 irmãos, eram 7, 4 deles foram para o Brasil e 3 ficaram cá, teve que se agarrar, a minha avó tinha que continuar o negócio, não poderia sobreviver de outra forma! O meu pai estudou na UTAD em Vila Real, foi dos primeiros alunos do antigo Instituto Politécnico de Vila Real (...). " (E3_F_3 ${ }^{a}$ Geração_Turismo)

"Compra a fábrica e põe aquilo em funcionamento e mandar um filho para Vila do Conde para aprender a reativar a fábrica porque ela tinha encerrado efetivamente a laboração." (E21_M_4a Geração_Indústria)

"O meu pai meteu-se nesta aventura depois de se reformar, ele era guarda-fiscal e na altura 55 anos, salvo erro, ainda tinha vigor de tal maneira que meteu-se nesta aventura que foi de facto empreendedora apesar de a ideia de negócio ser fácil, simples, mas recordo-me que nós, o meu pai apresentou o projeto, na altura à Direção Geral de Turismo, claro não existia nenhum parque de campismo classificado oficial ou legalizado na época (...)." (E8_M_2a Geração_Turismo)

“(..) razões puramente pessoais, de vivência feliz de uma infância extremamente feliz que tive aqui que me levara a fazer este investimento aqui e a dar origem à casa [**]." (E4_M_1ª Geração_Turismo)

“(...) de maneira que lancei em Inglaterra as primeiras latas de abertura fácil e a seguir no mercado português com a marca [ ${ }^{* * *}$ e a partir daí foi o mundo todo que foi atrás de nós!" (E16_M_5a Geração_Indústria)

"Garra, eu acho que é preciso ter garra e, também, acreditar e ter assim uma pontinha de sorte. Só se constrói um império com muita 
dedicação, que parte das pessoas, das sortes e de perceber aonde é que nós podemos caminhar, eu acho que é um bocado por aí" (E13_F_3a Geração_Indústria)

A interação, o relacionamento, o compromisso e o envolvimento do(a) fundador(a) e das primeiras gerações com as gerações vindouras são fatores que influenciam a sucessão. Nalgumas situações, tendem a ser recetivos às novas ideias e produtos, revelando que nem sempre o conservadorismo ou a maior resistência à mudança atribuída ao(à) fundador(a) é a regra.

"Fora digamos destas transições geracionais, um marco importante também foi o início da produção, quando começamos a produzir vintage, isto agora é mais uma questão mais de detalhe, muito dedicado ao universo do vinho, não tanto empresarial, mas durante muitos anos o meu bisavô sempre foi crítico a produzir nos vintages. O vintage é uma das categorias superiores do vinho do porto e achava que os vintage eram quase um monopólio das casas inglesas e achava se calhar, tinha a ver com uma certa confiança na empresa para produzir vintage e depois de muita insistência do meu pai e do meu tio ele lá cedeu e o primeiro vintage nasceu em 1960 (...)." (E6_M_4a Geração_Comércio)

"O meu tio era uma pessoa fantástica com um comportamento muito vincado, nas coisas boas mas também nas coisas menos boas, eu não lhe vou chamar más porque seria uma maldade á história e ao trabalho que ele desenvolveu, era uma pessoa com uma personalidade muito forte, nas coisas más era complicado de lidar, nas coisas boas era uma pessoa com uma capacidade de trabalho e de visão fora do vulgar para o período que atravessávamos nessa altura, para a formação base que o senhor $\left.{ }^{[* *}\right]$ tinha a $4^{\text {a }}$ classe, assim como os meus pais e a maior parte dos familiares que queriam criar negócios e empresas. De facto, era uma pessoa que estava um bocadinho á frente das pessoas do tempo dele (...)." (E12_M_2a Geração_Indústria).

“(...) o meu sogro foi uma pessoa que teve uma posição muito importante na sociedade portuguesa nomeadamente como presidente da Associação Comercial e de Comércio e Indústria do Porto, 12 anos e, portanto, lá está, outra característica que ele tinha, portanto, não era só a empresa, mas a preocupação sempre do desenvolvimento do país, a aposta na qualidade que eu comecei por falar, que há 67 anos não era fácil. Hoje é uma base, ou se tem qualidade, ou então não vamos lá!" (E14_M_4a Geração_Comércio)

\section{"Honrar a família": orgulho, lealdade, compromisso e confiança}

Umas das dimensões mais relevantes para quem se encontra à frente da atual empresa é "honrar a família". Assumir o legado dos avós, pais, tios, entre outros familiares, com orgulho, lealdade, compromisso e confiança constitui um traço comum das experiências de vida deste(a)s entrevistado(a)s. Continuar a história do negócio da família surge como um imperativo visível na esmagadora maioria dos discursos, ainda que tal implique "disponibilidade total" ou "privação de fins-de-semana" ou "dar 100\% ao negócio".

"A questão da empresa familiar acho que é um orgulho, a sério, porque eu entro aqui e sinto isso mesmo, gosto do cheiro a pele, do cheiro a cola! (...) Acho que acima de tudo além dos problemas, das coisas que são 
inerentes a uma empresa que não seja familiar ou seja familiar - uma empresa tem problemas desde que abre a porta até sair -, é que realmente nós sempre fomos, e o meu avô aí sempre foi um campeão, sempre nos uniu sempre estivemos muito juntos independentemente de tudo. Há problemas, temos de falar... e aí está a prova, 61 anos de existência! Temos que melhorar sim, para progredirmos e para estarmos mais competitivos, mas acima de tudo para estarmos unidos." (E13_F_3 ${ }^{a}$ Geração_Indústria)

"No fundo acho que o balanço é positivo, não me arrependo em nada de tomar a decisão (...) Acho que a decisão sempre foi de ficar cá. No fundo, a decisão foi uma questão de orgulho de família, de fazer questão de seguir a ideia inicial da minha avó, de respeitar a tradição, de valorizar a família, no fundo sempre foi isso!" (E3_F_3a Geração_Turismo)

"Eu já recebi uma proposta muito boa para deixar a empresa e monetariamente compensava-me muito mais, mas eu acho que a vida é muito curta para eu ter a minha família de costas viradas para mim e não aceitei, porque o dinheiro não pode ser tudo! Eu dou valor à família! Não quer dizer que vá ser sempre assim, nem quer dizer que os meus irmãos pensem da mesma maneira que eu, embora eu ache que sim. A minha posição perante a vida é esta, amanhã vamos ver!"

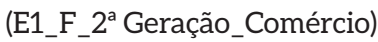

"Outra coisa que também acho muito importante, não só na relação interna digamos entre nós os quatro ou entre nós os seis mas é entre a família e a empresa que é tentar! Eu costumo dizer sempre que a empresa não é nossa, nós temos a sorte de trabalhar nela, alguém nos 'entregou a empresa', agora num sentido um bocado figurado e nós temos a sorte de facto de trabalhar aqui durante vinte, trinta, quarenta, o que for! É uma responsabilidade pegar na empresa e eventualmente deixá-la à geração seguinte melhor ainda do que quando a recebemos." (E6_M_4a Geração_Comércio)

"Gostávamos muito enquanto eramos pequeninos de vir para cá ao domingo. Aqui ainda não existia e deixávamos desenhos nas secretárias das pessoas todas" (E18_F_3 ${ }^{a}$ Geração_Construção)

"Eu atrevo-me a dizer que a família é o sítio em si, é o valor que está aqui, isto faz parte, é um património cultural." (E8_M_2 ${ }^{\text {a }}$ Geração_Turismo)

"Eu vim cá parar, eu cresci aqui, eu lembro-me da empresa quando era na parte de trás da casa do meu bisavô com $200 \mathrm{~m}^{2}$ depois quando mudamos para a Boavista, que ficava por trás da casa de saúde da Boavista $2000 \mathrm{~m}^{2}$, portanto, cresci aqui, formas para bolos com formatos diferentes isto para mim é básico! Toda a vida foi assim e é engraçado às vezes ver a reação das pessoas aos formatos e eu: 'para ti isto não existe desde sempre?' Para mim existe desde sempre." (E9_F_5a Geração_Indústria)

“(...) porque honramos o nome, honramos uma história, há uma memória e há uma cultura e há depois dessas partes todas, há um conjunto de pessoas e famílias que conseguimos manter um percurso de 20 anos em que as coisas nem sempre foram estáveis, nem sempre fáceis! Nunca falhamos os salários às pessoas, temos vindo a qualificar as pessoas e as condições de trabalho. Hoje se calhar somos reconhecidos também por isso, portanto, tudo isto é muito gratificante." (E11_F_2 ${ }^{a}$ Geração_Indústria) 


\section{Qualificar os membros familiares}

O European Family Business Barometer (KPMG, 2017) realça a capacidade de atrair, selecionar e reter as pessoas certas, denominada war for talent, como sendo a principal preocupação das empresas familiares. Quando no ambiente familiar surge um conjunto de membros da família que procura fazer parte da empresa, a força e a coesão da família tendem a influenciar as decisões da empresa. Da análise de alguns testemunhos, é possível registar posições diversas: umas mais orientadas para a qualificação académica e competência profissional; outras mais permeáveis à experiência e proximidade dos laços de parentesco. Independentemente do setor de atividade ou dimensão, regista-se um esforço muito significativo para a profissionalização da estrutura de governação da empresa por via dos membros familiares.

"A única pessoa que tem formação sou eu! Sou licenciada em Matemática, tenho uma pós-graduação em Educação e mestrado em Gestão na Universidade do Minho." (E1_F_2 ${ }^{a}$ Geração_Comércio)

"Eu tirei enologia. No final do curso temos uma cadeira de marketing, pela qual eu fiquei completamente apaixonada e, portanto, procurei logo trabalho em áreas relacionadas com o marketing." (E2_F_1 ${ }^{a}$ Geração_Consutoria)

"Eu estou mais na parte administrativa e financeira e também na parte do turismo. Toda essa responsabilidade passa por mim, claro que sempre com o apoio dele e com a opinião dele [pai]. E depois, entretanto, surgiu um master em Braga na católica em Gestão e Administração de Turismo. No fundo, o que eu acho que retirei de mais valia foi os contactos que fiz. Ainda hoje tenho ótimas relações! Se não tivesse frequentado o mestrado ou o doutoramento não tinha esses contactos e os conhecimentos que aprendi foram muitos, mais na parte das aulas e depois dos seminários." (E3_F_3 3a Geração_Turismo)

"E surgiram as máquinas de venda automática, depois surgiu a loja de café, mas fui buscar esse know-how com o sonho de ter a minha própria empresa, aproveitando o conhecimento e o capital que recebi durante 19 anos." (E4_M_1 ${ }^{\text {a }}$ Geração_Turismo)

"Acabei por fazer doutoramento e acho que isso trouxe algum upgrade no reconhecimento que as pessoas fazem da empresa que a procuram para fazer este tipo específico de trabalho, não é? Alguma confiança em termos profissionais associado à empresa." (E5_F_1 ${ }^{a}$ Geração_Consultoria)

"Estudei cá no Porto. Foi engraçado, porque eu estudei Serviço Social no Instituto Superior de Serviço Social. É a minha formação de base, depois fiz aqui, na Faculdade de Economia, uma pós-graduação na área da gestão, mas essa é a minha formação de base!" (E18_ F_2a Geração_Construção)

“(...) este meu perfil de liderança de assumir tudo, porque foi isso que eu fiz durante 30 anos, o meu pai era vivo mas eu assumi a empresa: 'não eu faço, eu quero saber, não se preocupe, eu trato!'. Isto sempre foi assim porque fazia parte do meu ADN! (...) há uns anos eu fiz um workshop no Porto com a Católica acerca do Marketing de Luxo" (E23_M_3a Geração_Comércio) 
"Quando me despedi pensei: 'o quê que eu vou fazer agora?' Falei com a minha mãe e disse "mãe, eu sei que é mais uma" porque ela não gosta que estejamos aqui todos, pronto, nesse aspeto ela sente um bocado de insegurança. Mas ela respondeu-me: 'lá estás tu, se a fábrica não corre tão bem, estamos todos aqui...', mas eu respondi: 'oh mãe!' e ela lá dizia "pensa bem, achas que estás a tomar a decisão certa!'(...)" (E13_F_3a Geração_Indústria)

Até então, muitos sucessores entravam na empresa familiar após completar níveis baixos de educação, assistindo-se à sua progressão na empresa. A presença desde tenra idade no quotidiano do negócio da família terá sido a estratégia latente para que muitos dos sucessores assumissem a empresa. Todavia, o investimento na qualificação académica e profissional constitui uma tendência indiscutível junto das gerações mais recentes. Esta mudança de perfil sociodemográfico do empresariado constitui um dos sinais mais importantes de dinamização do potencial de inovação e transformação do padrão de especialização produtivo.

\section{(In)formalidade das decisões e planeamento}

Para a sustentabilidade e profissionalização das empresas familiares importa assegurar a separação entre os interesses da família e os do negócio. Porém, a informalidade das decisões e do planeamento caracteriza o modelo de governação assumido maioritariamente pelas empresas familiares. Por força da influência da família sobre as decisões empresariais, as empresas familiares são mais permeáveis à informalidade das decisões, à inexistência de circuitos de comunicação estruturados, bem como de planeamento estratégico a médio e longo prazo.

Os discursos analisados permitem perceber que o processo de decisão nas empresas familiares é influenciado pela visão da família. Muitas das decisões são suportadas por fatores emocionais, de cariz intangível ancorados em laços familiares e afetivos, do que por interesses estritamente empresariais.

“(...) As empresas pequenas e, particularmente as familiares, não obedecem muitas vezes a uma estrutura formal de termos um plano estratégico que não está escrito. Esta fábrica está aqui em autogestão! Só quando o meu irmão cá vem que coordena, põe, deixa os trabalhos e isto e aquilo e quando não está pode correr bem ou pode correr mal (...). Agora já cá está a minha cunhada que vai ajudar!" (E7_M_2a Geração_Indústria)

"Quando estamos a falar mais da parte da fábrica, o meu irmão e eu, mas também sempre um bocadinho cada um de nós, dá a sua opinião, portanto, não há um circuito formal! Estamos a tentar criá-lo para também precaver algumas situações, mas formalmente não existe nada definido." (E3-F_3a Geração_Turismo)

"Há decisões que o pai pode tomar sozinho e não toma sem nos falar. Ele gosta sempre de acolher as opiniões. No dia-a-dia, coisas básicas ele não nos diz nada, mas quando é uma decisão sobre uma obra ou trabalho, um investimento, ele gosta de nos falar, perguntar o que nós achamos. Portanto, isto quase sempre funciona nos dois sentidos!" (E18_ F_2a Geração_Construção) 
"Mas de uma maneira muito informal, muito direta, digamos não há muitas reuniões, nem muitas atas, é muito flexível e tomamos decisões muito rapidamente." (E17_M_3 ${ }^{\text {a }}$ Geração_Comércio)

"Reunimos! Não lhe vou dizer que é assim estruturado e com dia marcado. É efetivamente consoante a necessidade e com aquilo que vai aparecendo; fazemos aqui não fazemos em casa, trabalhamos aqui e vamos partilhando. Se eu decido que gostava de fazer uma feira eu digo-lhe: 'olha estava a pensar fazer esta feira neste local, o que achas? Devo ir, não devo ir?' Partilhamos (...) conversamos." (E9_F_5 Geração_Indústria)

"É feita num modo muito anárquico! Nas decisões estratégicas é, neste momento, um bocado navegar à vista para lhe ser sincero! É tentar ir percebendo quais são as necessidades do mercado, tentando perspetivar outras culturas e tentar ir satisfazendo-as" (E15_M_3a Geração_Indústria)

A flexibilidade associada às relações informais no sentido da rapidez da tomada de decisão, a par da confiança que têm nos familiares que integram a direção, são aspetos muito valorizados nestas empresas. A importância do "rosto" por detrás do negócio reforça o caracter distintivo do mesmo.

"Nós tentamos sempre que esteja cá um de nós, não tem a ver com desconfiança, tem a ver com o facto de que possa estar alguém que possa dar a cara quando vem alguém e precisa de algum esclarecimento adicional e mesmo para os funcionários perceberem que está sempre aqui alguém responsável." (E1_F_2a Geração_Comércio)
“(..) Tive 15 anos de hierarquia, mas sinceramente para mim, independentemente de ser mãe, ela aqui dentro é patroa! (...) Não faço nada sem o aval da minha mãe, nem dos meus tios, porque realmente são eles os patrões e nós somos da terceira geração, mas eles ainda cá estão e a gente tem de dar conhecimento às hierarquias. Mas não é aquela coisa difícil de falar! É fácil!" (E13_F_3 ${ }^{a}$ Geração_Indústria)

A prevalência de critérios profissionais na tomada decisão sobre a propriedade, governo e gestão da empresa e a existência de uma estrutura organizativa com definição de funções e responsabilidades é central na vida de qualquer empresa. Tal implica desenvolver uma estrutura de governance que permita organizar processos e procedimentos que estão na base da tomada de decisão no sentido de a tornar menos propensa à influência de fatores emocionais e mais rigorosa e objetiva. Há alguns testemunhos que ilustram os esforços de formalização de procedimentos, reuniões e órgãos de governo da empresa.

"Normalmente temos por hábito reunir com uma regularidade, com uma regularidade pouco regular, ou seja, não temos uma regra tipo uma vez por mês, não temos nada disso e se calhar devíamos, porque se calhar muitas vezes quando chegamos às reuniões já temos uma pilha de coisas para falar! Mas temos por hábito reunir. (...) Regras escritas ou, não, são coisas de muito bom senso e que são boas práticas! Há simplesmente coisas que, ao longo do tempo, nós fomo-nos apercebendo que se calhar as pessoas tinham perceção errada de que nós efetivamente estávamos a ser beneficiados." (E6_M_4 ${ }^{a}$ Geração_Comércio) 
"Eu acho que [as regras] têm de estar pelo menos protocoladas e claras, porque a família pode entender, por exemplo, que em cargos da direção só estão elementos da família, nada contra. Isto deve estar claro para todos os elementos da empresa!" (E2_F_1 ${ }^{\text {a }}$ Geração_Consultoria)

“(...) depois criamos um conselho de gestão onde estão dois elementos externos, o meu filho e a minha filha que reportam à administração. É evidente que fizemos um conselho de gestão, aliás o conselho de gestão seguimos o exemplo de uma representada alemã com quem trabalhamos há 40 anos que tem uma fórmula semelhante e nós seguimos em boa hora porque é um bom exemplo!" (E14_M_3a Geração_Comércio)

\section{Manutenção do negócio nas "mãos" da família}

Mais importante na vida destas empresas reside na postura de reserva quanto à entrada de membros não familiares na gestão da empresa. O reconhecimento e o valor atribuídos ao negócio de família surgem mais uma vez reforçados nas suas narrativas, destacando a importância da manutenção do negócio nas "mãos" da família.

"Eu acho que por mim e meu irmão, mas também o meu pai partilham desta opinião. Já tivemos uma proposta para aquisição da [***], várias propostas até, duas principalmente! Mas isso nunca se pôs; a empresa é de cariz familiar e pretendemos mantê-la". (E3_F_3 3a Geração_Turismo)

"Não estamos dispostos obviamente a ceder posição de acionista ou de gestor ou de administradora a ninguém fora da família." (E19_M_1ª Geração_Indústria)

"Não acho que um gestor externo ia fazer muito mais do que fazemos! Claro que traria com certeza algum lado bom, mas tendo em conta que esta empresa é gerida muito criteriosamente e tem tantas possibilidades a vários níveis não me parece que traga aqui nada de novo (...)." (E18_F_2 Geração_Construção)

"A questão familiar desde logo foi muito vincada! Recordo o dia com particular importância porque o meu pai me deu um abraço, por ajudar o meu tio, por participar no projeto, por me preparar para o futuro e quando contei à minha mãe que ia trabalhar com o irmão mais velho dela ela chorou mais ou menos durante três dias!" (E12_M_2 ${ }^{\mathrm{a}}$ Geração_Indústria)

A ausência de membros não familiares ultrapassa os $90 \%$, indiciando claramente o quanto estas empresas se apresentam reservadas e fechadas à sua entrada. Além disso, privilegiam sobretudo relações de parentesco por via de laços de sangue na estrutura de governo da mesma. Nesse sentido, são situações pontuais as que reportam alguns dos testemunhos recolhidos quanto à possibilidade de admitirem ter "gestores externos" e, em especial, em admitirem, no limite, procurar outro projeto/ área de negócio ou vender a empresa.

"Mas se calhar admito que devia estar melhor protocolado, se eu me afastasse da empresa e se tivesse aqui um CEO profissional se calhar a empresa tinha a ganhar em muitas coisas." (E7_M_2a Geração_Indústria)

"Não tenho perspetiva nenhuma de seguir isto na família! Daí eu procurar outro tipo 
de projeto porque se for por uma questão de geração de sucessão não vai acontecer. Só tenho este filho não vou ter mais, por isso, não vai acontecer de certeza, nem com nenhum sobrinho, nada disso! Nem nenhum deles está virado para esta área. Tenho também uma sobrinha arquiteta, mas é arquitetura não tem a ver diretamente com esta área. Esta é uma empresa que vai morrer naturalmente, há que criar outra." (E5_F_1 ${ }^{\text {a }}$ Geração_Consultoria)

"Pode ser [ter de vender], eu gostava que isto continuasse até porque oportunisticamente seria uma solução muito mais confortável para mim! Chegar a um ponto em que seja necessário dissolver uma empresa não é agradável! É uma situação muito complexa ter que o fazer a nível financeiro e a nível pessoal, é uma situação sempre muito dolorosa penso eu!" (E15_M_3a Geração_Indústria)

\section{Naturalização e adiamento da sucessão familiar}

O processo de sucessão é descrito como um ajustamento mútuo entre o papel do(a) fundador(a) e o da próxima geração e um percurso evolutivo, tal como atrás descrevemos.

À medida que os membros da família vão aumentando e apesar de haver um maior número de opções para a escolha do sucessor executivo, pode existir um maior número de membros da família que não desejem trabalhar na empresa familiar, ainda que perspetivem retirar benefícios dela. Estas atitudes podem gerar, por um lado, tensão no seio da família e nos membros que trabalham na empresa versus os que não trabalham e, por outro, podem exacerbar conflitos existentes. Daí que seja vital estabelecer regras de conduta que definam como a família interage na gestão, através da definição de estruturas de governance de modo a promover a continuidade da empresa familiar e a protegê-la de eventuais conflitos e discórdias.

Apesar da sucessão executiva ser um dos maiores desafios que a empresa familiar enfrenta, este é um tema que não foi ainda devidamente enfrentado por estas empresas. Dos testemunhos recolhidos a questão da sucessão não se coloca para já, e a ser equacionada a mesma é perspetivada em termos de se assegurar a sua passagem natural pelos descendentes diretos ou indiretos.
"Não [pensei na sucessão]! Tenho dois filhos e, portanto, eles também gostam muito deste espaço. A sucessão naturalmente será deles, será deles, mas vamos fazer um ponto de si- tuação ao fim de dois anos, vamos aguardar!" (E4_M_1 ${ }^{a}$ geração_Turismo)

"Ainda é cedo, porque o meu irmão tem duas filhas, eu tenho um rapaz, sendo que esta empresa está no nome só de um deles, muito provavelmente não irá mudar! Vai depender da vontade das filhas, ele ainda vai ao terceiro, ainda vai à procura do rapaz (...)." (E1_F_2 Geração_ Comércio)

"Para já [os filhos] ainda estão a estudar e são pequeninos apesar de o mais velho já nos fazer alguns apoios ao fim de semana. Já foi fazer connosco algumas incidências em termos de algumas máquinas e ajudar-nos. No fundo para lhes incutir também a responsabilidade e de ganhar o seu próprio dinheirinho para as coisinhas dele, ter a parte com remuneração, também acaba por ser aliciante para eles." (E20_F_1 ${ }^{a}$ Geração_Consultoria)

"Gostava que isto fosse para um filho ou para 
um sobrinho que pudesse ter algum tipo de sucessão. Era em todos os aspetos mais confortável!" (E15_M_3a Geração_Indústria)

As narrativas analisadas enfatizam o adiamento na formalização da sucessão, sendo residuais aquelas em que o(a) entrevistado(a) assume que já pensou num protocolo familiar em que se definem as regras ou procedimentos a seguir na preparação da sucessão da liderança/ gestão da empresa.

"Já pensamos! Numa altura tivemos uma reunião com a Associação de Empresas Familiares, (...) e na altura ainda se pensou fazer o protocolo familiar, tivemos a caminhar para isso (...) Eu acho que é importante o protocolo familiar porque é preciso acautelar algumas situações que podem acontecer!" (E3_F_3 ${ }^{a}$ Geração_Turismo)

"Mais uma vez por ordem natural das coisas é normal que daqui a uns anos que o capital fique mais disperso porque as pessoas vão ter mais filhos, ou ir para fora, não sei... mas se calhar basta em vinte anos, trinta anos e a estrutura do capital vai ser muito diferente do que é hoje. Uma das coisas que se tem falado, embora não se tenha ainda operacionalizado nada, é justamente arranjar um conjunto de regras e aí sim, escrita e formalizadas, relativas à família em que defina várias coisas. Por exemplo, em que circunstâncias um membro da família pode trabalhar na empresa; em que circunstâncias um acionista que, por algum motivo, quer vender a sua quota, ou parte da sua quota, o faz; se há preferência dos outros membros e se há preferência em que condições; a idade da reforma das pessoas que trabalham cá... É algo que nós temos vindo a falar e acho que era importante!" (E6_M_4 ${ }^{a}$ Geração_Comércio)

\begin{abstract}
"Uma coisa que eu aprendi (...) numas formações que houve sobre a sucessão foi aí que comecei a questionar-me sobre o futuro, a divisão da empresa, os acionistas... depois há aquela coisa das empresas que costumam morrer na terceira geração! Comecei a pensar, porque depois são filhos e depois já começam os primos e nós temos uma quinta geração diferente. Portanto, passou de um pai para o filho e depois há aqui a entrada da terceira, quarta geração, mas de maneira diferente (...) A questão dos filhos e do envolvimento dos filhos acho que tem que ser pensado e tem que ser preparado" (E9_F_5 ${ }^{\text {a }}$ Geração_Indústria)
\end{abstract}

A acontecer a sucessão, não isenta de conflitos, a sua preparação foi decisiva, tal como se pode verificar na passagem do seguinte testemunho.

"Em 2001, o meu pai e o meu tio perceberam que esta empresa para ter continuidade dependiam de nós e que o capital que eles tinha aqui investido se o vendessem nunca o conseguiam vender pelo valor, um valor interessante para eles! Então, eles entenderam que se nos fizessem a doação ou nos dessem a oportunidade de dar continuidade eles podiam ter um rendimento fixo, constante até à sua morte. $E$ foi isso que aconteceu, houve acordos, houve reuniões e eles perceberam que nós [eu e a minha irmã] seriamos os continuadores. Foi, mas foi preparada por ele por nossa decisão, nós dissemos, nós queremos garantias, não quero estar a trabalhar aqui a 10 ou 20 anos ou ao nosso falecimento nós andarmos aqui todos à bofetada, vamos então definir no dia em que isso acontecer como é que vai acontecer, que garantias é que vocês nos vão dar? (...) É um documento ... há uma parte que era por doação e uma parte era usufruto e o usufruto podia ser a 
qualquer momento reclamado (...). Houve conflitos como é óbvio, houve divergências de opinião, houve momentos que parecia que isto não ia dar em nada. Andou-se para a frente, andou-se para trás, mas deu certo! Acho que há mérito, neste caso, do meu pai e do meu tio por aceitarem mas também há mérito nosso porque nós lhe demos garantias de que eles iam ficar ligados, seguros!" (E23_M_3a Geração_Comércio)

\section{Liderar no feminino}

O papel crucial que as empresas familiares desempenham e a importância que têm na economia é inquestionável. Além do potencial de inovação de que são expressão pela elevação do nível de qualificação dos seus líderes, com expressão superior à média dos gestores das empresas não familiares como vimos, acresce a significativa importância do lugar das mulheres no topo da hierarquia. Seja porque são proprietárias/ acionistas, seja porque assumem cargos de direção, as empresas familiares são palco de transformações relevantes. Estas são visíveis nas mudanças dos padrões de segregação ocupacional, com mulheres empresárias, por exemplo, em setores tradicionais, como a metalúrgica, mas também na segregação vertical, a mais expressiva no contexto deste estudo.

Ocupar lugares de topo na efetividade de funções tem vindo a ser relevante ao nível de $2^{\mathrm{a}} \mathrm{e}$ $3^{a}$ gerações das empresas familiares. A escolha desta liderança no "feminino" pode ser alicerçada pelo facto de os descendentes serem apenas mulheres, mas também no perfil demonstrado pela mulher. Além disso, importa ter presente que muitas gestoras/ proprietárias tendem a apresentar níveis de qualificação escolares mais ajustados a áreas específicas do negócio.
"O meu pai disse: 'Oh filhota eu estava aqui a pensar se tu querias ir trabalhar para a fábrica?' Eu fiquei assim a olhar para ele, para a fábrica? É que eu não estou a ver as tuas irmãs! Se não fores tu, não estou a ver qual delas se adapta à realidade." (E9_F_5 ${ }^{\mathrm{a}}$ Geração Indústria)

"Nós aqui temos homens e mulheres na empresa, no fundo, mais na direção da empresa, se calhar beneficiando nalguns aspetos no facto de eu ser mulher, ter outro tipo de sensibilidades que se calhar os homens não têm! (...) Sim, continua ainda a ser um mundo muito masculino! Mas eu defendo que nós devemos ter a nossa personalidade, nunca refleti muito sobre a questão de o facto de eu ser mulher limita ou ajuda... Nalgumas situações, obviamente quando vamos a uma feira o facto de ser uma senhora, pode até numa fase inicial chamar mais o possível cliente, o eventual cliente, mas depois o resto tem de corresponder senão a coisa depois ficará por ali." (E3_F_3 ${ }^{a}$ Geração_Turismo)

"A experiência é positiva! Para além de ser uma mulher que está numa empresa - e tenho tido algumas propostas de trabalho fora - faço parte de algumas associações precisamente por ser uma mulher que estou ligada à gestão de uma empresa. Isso de certa forma abre algumas portas e ao nível do reconhecimento. É bom ver que as pessoas reconhecem e viram como a empresa evoluiu nestes poucos anos que tem." (E1_F_2a Geração_Comércio)

"Eu não sei se na altura não fui levada tão a sério por ser mulher, perante homens também estrangeiros, mais velhos não sei até que ponto (...) Eu estou agora a recordar-me 
do último desafio grande para ficar aqui com uma representação importante e a determinada altura eu tinha dois senhores e um deles ria-se na minha cara, a pensar ela não esta bem da cabeça, com o que ela vem aqui propor-nos! Porque a determinada altura eles queriam uma parceria exclusiva e eu dizia que não, porque não tinha que abdicar de outras parcerias que tinha para ter (...) Na hora de pôr as minhas cartas em cima da mesa e de convencer e de argumentar isso [ser mulher] para mim até me dá mais força! Já estamos num mundo em que se as coisas forem feitas com profissionalismo negócios são negócios independentemente de ser homem ou mulher!' (E2_F_1ª Geração_Consultoria)

"Nós temos uma mulher à frente na direção que é a $\left.{ }^{* * *}\right]$... alguém tem de tomar a decisão, aliás ela tem autonomia suficiente para trabalhar! (E21_M_4ª Geração_Indústria)

"É factual que as mulheres têm tido menos oportunidades que os homens, têm salários mais baixos que os homens! Isso é evidente que tem acontecido, mas eu pessoalmente gosto de olhar para as pessoas, ou seja, saber se é um profissional, quer seja masculino ou feminino! Se desempenhar o seu papel bem feito terá as suas oportunidades e terá o seu espaço (...)" (E6_M_4ª Geração_Comércio)

\section{Conciliação (difícil) da vida familiar com a empresa}

As famílias têm influência vital nas empresas familiares. A cultura da empresa familiar é, regra geral, o resultado dos valores e ambição incutida pela família, da sua história e das relações e comportamentos sociais entre membros da família. As interações entre os vários membros da família conduzem à internalização de certos comportamentos, normas e valores no seio da empresa.

É certo que a conciliação da vida familiar com as exigências a tempo inteiro do exercício da liderança da empresa não se encontra imune aos custos associados à qualidade de vida familiar, ao tempo livre para a vida privada e lazer. Se, por um lado, há o registo de uma identificação com o negócio de família, o prazer e o orgulho associados à sua reputação e ao legado do fundador, como vimos, há também a consciência da necessidade de dedicação a tempo inteiro ao negócio e as consequências daí decorrentes na vida do cônjuge e filhos.

"Claramente, muito menos tampo, não há horários e, portanto, as coisas são bastante mais complexas nesse aspeto (...). Isto é quase como o sacerdócio é quase como entrar para o mosteiro! (E15_M_3a Geração_Indústria)

"No fundo acho que o negócio em si absorve muito das relações familiares. Pode ser mau, pode ser bom, há momentos para tudo, portanto, há momentos em que uma pessoa pensa que se calhar passou a vida a trabalhar, mas também outros momentos que nos dá um gozo terrível. Portanto, há momentos para tudo." (E3_3ª Geração_Turismo)

"Enquanto mulheres, misturamos o lado família e depois o ser mães e gerir tudo isto, acho que há vantagens e desvantagens, acho que há faturas a pagar se nós não soubermos de facto fazer as coisas no seu devido momento! No meu caso em particular, tendo dois filhos pequenos às vezes o difícil é conseguir conciliar, mas há as ajudas e depois 
há a próprio obrigação de desacelerar, de dizer não! Calma que amanhã também é dia! (E2_M_1 ${ }^{a}$ Geração_Consultoria)

"Na parte da minha família, digamos da minha mulher e dos meus filhos eu acho que eles sofrem um bocadinho, sobretudo porque eu viajo bastante, não só porque me envolvo muito na empresa e vivo muito na empresa (...) porque quando eu vou viajar ela tem que ficar sozinha com os miúdos e para os meus filhos também é difícil (...) sentem bastante essas ausências." (E6_M_4 ${ }^{a}$ Geração_Comércio)

“(...) às vezes os miúdos ao domingo estão aqui com o pai e a minha mulher vai gerindo as coisas delas e vem cá ter e vem buscá-los. Ainda ontem estivemos aqui porque tivemos aqui uma situação familiar e os meus filhos disseram: 'Oh pai se quiseres ficar aí mais um bocadinho para acabares o trabalho nós vamos para casa'. Portanto, vale a pena porque existe este conceito de acordo familiar, de casa, de que todos temos de trabalhar. Neste momento sou eu que faço essa gestão do trabalho mas nem sempre consigo conciliar a importância que dou ao trabalho com a importância que deixo de dar à família." (E12_M_2a Geração_Indústria)

"Há uma coisa que ele diz que é: 'a mamã trabalha muito!', porque aqui quando temos uma função destas e estamos a frente de uma empresa as horas não se conta! (...) Às vezes a família é um bocadinho prejudicada pelo tempo que eu estou cá, porque eu estou cá muitas horas, o meu irmão está cá muitas horas. E depois há sempre um telefonema, há sempre algo que vem, os colaboradores vêm ao final de tarde, final de tarde e querem falar connosco eu não vou virar as costas!
Temos de estar disponíveis aqui, portanto, eu podia entrar mais tarde, podia, mas também não consigo porque muitos querem falar connosco de manhã quando saem para as obras. Eu normalmente chego cedo e saio tarde, tento compensar a família de alguma forma, quando estou com eles estou mesmo." (E18_F_2 ${ }^{a}$ Geração_Construção)

\section{Descentralizar, desburocratizar e legislar}

Reconhece-se o papel de relevo das empresas familiares na economia local, nacional e internacional, na criação de riqueza e emprego, e na sustentabilidade e desenvolvimento das comunidades locais em que se inserem. Todavia, em termos de visibilidade institucional, esta tipologia empresarial tende a não ser destacada na agenda política, em especial, pela tradicional postura de reserva e de discrição das empresas familiares em geral, e pela singularidade dos desafios e características que assumem, em particular. Decorrente da integração e interação da esfera familiar com a esfera da empresa, assinale-se, por exemplo, as seguintes especificidades das empresas familiares: dificuldades de internacionalização e incorporação da inovação; preparação da sucessão; planeamento estratégico e liderança; e gestão de conflitos da interseção empresa e família e pressão para o seu equilíbrio. Não obstante, o conjunto de recursos e as competências idiossincráticas que coexistem nestas empresas podem traduzir-se numa vantagem competitiva. Acresce ainda que a visão de longo-prazo, a cultura organizacional e a reduzida exposição ao risco contribuem também para a sua vantagem competitiva e representam elementos fundamentais para o seu sucesso. Neste contexto, importa conferir maior visibilidade quer às especificidades e preocupações, quer aos 
desafios que enfrentam, interpelando a atenção dos decisores políticos das áreas que tutelam para esta temática.

Descentralizar, desburocratizar e legislar são termos que perpassam pelo discurso do(a)s entrevistado(a)s. A simplificação dos processos associados à atividade económica em si, a facilitação ao nível da internacionalização do negócio, o enquadramento legal adequado aos projetos, são algumas das recomendações sinalizadas.

"O meu primo tem uma expressão que é uma piada que é: 'Para o Estado é uma chatice haver empresas! É uma chatice e a verdade é que eu inicialmente não concordava com ele, mas eu cada vez mais concordo com ele, porque parece que nós somos um problema no meu disto tudo, um empecilho (...) porque os problemas que se criam, as burocracias que as pessoas são obrigadas a fazer! Para já é típico de alguém que nunca trabalhou uma empresa (...)." (E6_M_4a Geração_Comércio)

"Há todo um processo burocrático e poder ser mais ágil no sentido de candidaturas a apoios, mas depois no terreno as pessoas não têm essa resposta! Realmente há uma melhoria que tem de ser feita, uma articulação melhor por parte do governo, com maior dotação financeira porque há o retorno em termos do turismo, mesmo para a própria economia em que o governo é parte integrante dessa gestão há retorno!" (E4_M_1 ${ }^{a}$ Geração_Turismo)

"Em primeiro lugar acho que é preciso descentralizar, mesmo, não ser só palavra! Descentralizar, desburocratizar, tornar as coisas muito mais ágeis, mais leves, mais rápidas. Depois acho que tem que acompanhar isso uma mudança de mentalidade muito grande e dizer, ali também há gente que faz as coisas, não é só no litoral, não é só nas grandes cidades! Depois, ter legislação para que permitisse avançar com o projeto, ou seja, as câmaras, as entidades não sabiam como é que haviam de fazer (...)" (E5_F_1'a Geração_Consultoria)

"Sugeria que as pessoas se sentassem um bocadinho com quem de direito, que saíssem um bocadinho de Lisboa (...) que fossem um bocadinho aos locais, que vissem a realidade, que falassem, que nos ouvissem, antes de tomar uma decisão e pôr um orçamento de Estado aprovado." (E11_F_2a Geração_Indústria)

"Isto foi uma grande luta porque o licenciamento da Câmara, vizinhos... há sempre queixas com uma indústria debaixo de prédios, não é?" (E19_M_1ª Geração_Indústria).

"Aí sim se calhar o Estado podia ter um papel mais diplomata, de abertura de algumas fronteiras ou então limitar o próprio acesso ao nosso mercado, porque se nós queremos ir para outros lados temos as portas todas fechadas. E nós abrimos tudo não é? Deixamos entrar o que quiserem." (E3_3 ${ }^{a}$ Geração_Turismo)

"A empresa é cumpridora, com antiguidade com quase meio século e o Estado nem pega! Agora consegue ver facilmente num computador, olha estes nasceram no ano tal estamos no ano tal, nunca houve incumprimentos, vamos beneficia-los! (...) O nosso intuito é pagar criteriosamente, religiosamente, ao Estado e o Estado nunca nos reconheceu nada (...)" (E18_F_2a Geração_Construção)

"Se alguma coisa houvesse a fazer em relação às empresas familiares eu 
diria eventualmente o tratamento fiscal na sucessão de quotas (...)." (E7_M_2 ${ }^{a}$ Geração_Indústria)

Não obstante, perpassam também o reconhecimento do avanço político, económico e social do país nas últimas décadas e, sobretudo, a mudança em curso ao nível da abertura do país ao turismo e à cultura. Associada a esta revalorização, alguns testemunhos reforçam a importância dos decisores apoiarem as empresas em si, independentemente de serem ou não empresas familiares, disponibilizando condições e infraestruturas adequadas.

"Eu acho que não deve ser diferenciadas, não vejo motivo! Acho que hoje em dia a política devia de olhar mais para as empresas e acaricia-las porque são elas que criam riqueza, criam emprego e etc. mas diferenciar por ser familiar ou não, acho que não é por ai! (E17_M_3a Geração_Comércio)

"Eu penso que a cerâmica portuguesa é um produto que pode ter futuro! Nós continuamos a ter pastas, porque a cerâmica não se produz, a cerâmica existe, a cerâmica é uma exploração mineral que demora milhões de anos a ser formada. Neste momento, tenho conhecimento que algumas empresas de exploração de pastas estão a exportar pasta diretamente para outros países nomeadamente Itália e Turquia, por exemplo. Temos pastas de muito boa qualidade, deveria haver um estudo sério sobre que jazidas de pasta existem porque é uma riqueza muito, muito grande para a indústria da cerâmica e outras indústrias que se constroem em cima!
(E15_M-3 $3^{\mathrm{a}}$ Geração_Indústria)

"É uma questão cultural! Enquanto nós consumidores, cada um dos portugueses tem mais tendência a valorizar mais o que é de fora do que os nossos próprios produtos! Se mudássemos os nosso hábitos e fossemos um bocadinho mais como os espanhóis - serem muito mais nacionalistas - isto poderia contribuir para nós tivéssemos uma economia muito melhor a todos os níveis! (...) O Estado pode até estar a querer simplificar processos para desburocratizar, agora a culpa não é do Estado, a culpa é nossa, dos que não trabalham para que o país possa crescer. Os decisores políticos têm de dar atenção aquilo para que é digno de ter a atenção, têm que resolver os problemas é para isso que eles são pagos, vamos cá ver uma coisa, imaginemos isto, uma empresa não é uma boa empresa só porque é familiar ou só porque é uma mega

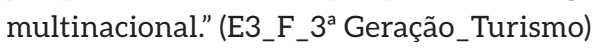

"Eu acho que problema não se põe só no Estado, nos governantes, mas põe-se muito mais nas pessoas, nas famílias! (...) Os desafios de hoje são mais exigentes e são mais rápidos do que eram no passado e hoje tudo acontece muito rápido e é preciso que as pessoas se preparem para continuar nos negócios independentemente da função que têm no capital da empresa." (E12_M_2 ${ }^{\text {a }}$ Geração_Indústria) 


\section{CONCLUSÃO}

Em Portugal, as Empresas Familiares (EFs) são um pilar da economia em termos de criação de riqueza e de emprego. Estas são a base predominante do tecido empresarial do país, sendo inegável a representatividade desta forma empresarial na região Norte. Com o mapeamento, os retratos e os testemunhos recolhidos neste estudo, pretende-se conferir visibilidade e dimensão económica e social às EFs, podendo servir de base para a formulação de políticas e programas de apoio por parte dos diversos decisores políticos.

Dos resultados obtidos, destaque-se o importante dinamismo das EFs da região Norte na sua capacidade de criação de emprego. Em Portugal, perante o contexto de crise financeira e económica entre 2011 e 2015, sob o Memorando da Troika, ressalve-se a importância destas empresas na estabilização da sua mão de obra (em muitos casos, com fortes custos internos à gestão da mesma), mas, mais importante, na criação de emprego numa conjuntura adversa. As empresas procuram sobretudo trabalhadores com experiência profissional, mas também jovens com qualificações técnico-profissionais ajustadas ao negócio da empresa e ainda jovens com qualificações académicas superiores.

A qualificação da geração atual à frente dos negócios da família constitui, igualmente, um dos traços mais significativos e distintivos destas empresas familiares, quando comparadas com as empresas em geral. A progressiva qualificação dos portugueses tem vindo a se inscrever nos desígnios das políticas públicas, por via do cumprimento das metas da União Europeia.
De forma consensual admite-se que Portugal registou uma profunda transição educativa nas últimas duas décadas. Com uma elevação do nível médio de qualificação geral, estas gerações de empresário(a)s testemunham o investimento recente em políticas educativas e iniciativas específicas de qualificação e reconhecimento de competências profissionais.

Em geral, a empresa familiar é tradicionalmente caraterizada por baixos níveis de propensão ao risco, optando por recorrer a capitais próprios e, assim, manter os seus níveis de endividamento de longo prazo reduzidos. Este tipo de comportamento permite às empresas defenderem-se de uma possível perda de controlo da sua gestão/ liderança. Importa equacionar também o facto de muitas empresas familiares recorrerem a capitais próprios porque não conseguem aceder a outro tipo de formas de financiamento. Dos nossos resultados, fica evidente que a performance empresarial das empresas familiares tende a ser influenciada não somente pela sua dimensão, como também pela sua antiguidade. Por um lado, quanto maior a dimensão da empresa familiar menos se recorre ao autofinanciamento e aos fundos familiares, como se regista um aumento do peso das exportações no volume total de negócios, da capacidade de I\&D, assim como a certificação da qualidade e o envolvimento em processos de inovação. O mesmo tende a se verificar à medida que a sua gestão regista uma renovação de gerações.

Por sua vez, os recursos financeiros, as áreas de negócio privilegiadas, as estratégias de internacionalização e inovação constituem alavancas 
cada vez mais importantes para a vantagem competitiva junto das EFs. O desafio da internacionalização em mercados além-fronteiras assume uma relevância indiscutível no contexto das empresas familiares. Todavia, assinale-se esta vertente como dimensão mais crítica, em especial para as empresas familiares de menor dimensão. A escassez de recursos financeiros e o conhecimento sobre potenciais mercados tendem a constranger a sua capacidade de internacionalização. Todavia, é pelo esforço de internacionalização que as empresas familiares poderão melhor se posicionar no mercado global, com alargamento dos seus mercados além-fronteiras de modo a aumentar o seu volume de negócios. Fica patente que a variável tempo é crucial para o processo de maturação da internacionalização e dos bons resultados daí decorrentes, mas também da implementação de condições adequadas, tais como, por exemplo: aumento da qualificação dos recursos humanos, o redimensionamento de equipas; a otimização dos processos produtivos para manter a competitividade de produtos e serviços e o aumento da capacidade produtiva instalada.

O desafio da inovação interpela-nos também na discussão dos resultados obtidos. Não é consensual que as empresas familiares dinamizem mais a inovação do que as não familiares: uns defendem que as empresas familiares tendem a ser mais conservadoras e avessas ao risco, assumindo um comportamento estratégico de resistência à mudança; outros autores defendem que a lealdade e a confiança das empresas familiares permitem sustentar relacionamentos de longo prazo e o acesso privilegiado a uma rede de parceiros que apoia o processo de inovação. Segundo os nossos resultados, são relativamente poucas as empresas familiares que se encontraram envolvidas em processos de inovação nos últimos três anos, e as que que o fizeram, essa inovação traduz-se diretamente na introdução de novos produtos e/ ou serviços, pelo registo de patentes ou, de forma indireta, pela melhoria dos processos na criação de valor. Do perfil das empresas estudadadas, importa registar o maior protagonismo por parte de empresas de maior dimensão, bem como as que se encontram mais consolidadas no mercado em termos de antiguidade. De realçar ainda que as empresas com menos de cinco anos envolvidas na inovação têm investido exclusivamente no registo das patentes.

Apesar da importância da certificação da qualidade, os nossos resultados revelam uma posição ainda frágil a este nível. Menos de $30 \%$ das EFs têm sistemas de gestão de qualidade suportados em normas e integradas na sua cultura organizacional como valores essenciais da empresa. Predomina o registo da informalidade dos processos de decisão e na maioria das vezes centrados na figura do(a) fundador(a). Não obstante, registe-se que as EFs têm vindo a adotar sistemas de reciclagem e tratamento de resíduos, integrando-os largamente nas suas políticas de preservação ambiental. Estas constituem-se cada vez mais num fator de valorização que o consumidor faz do produto final que poderá ser explorado numa perspetiva mais altruísta ou de marketing social, mas também essencial para garantir uma eficiente utilização dos recursos e, assim, contribuir, de forma mais direta, para a rentabilidade da empresa.

Reconhece-se a singularidade desta tipologia empresarial decorrente da integração e interação da esfera familiar com a esfera da empresa, que lhe confere características e desafios únicos como, por exemplo, preparação da sucessão, planeamento estratégico e liderança, gestão do conflito empresa e família. A dimensão intangível das EFs, com destaque para o capital social, 
relacional e simbólico, traduz-se na mobilização de recursos, humanos e financeiros, que condicionam a sua estratégia e resultados. Este conjunto de recursos e competências idiossincráticas (efeito familiness) pode traduzir-se numa vantagem competitiva. Acresce ainda que a visão de longo-prazo, a cultura organizacional e a reduzida exposição ao risco contribuem também para a sua vantagem competitiva e representam elementos fundamentais para o sucesso das empresas familiares.

Com efeito, fica patente que a permanência das empresas ao longo das gerações constitui um dos principais desafios e especificidades desta tipologia empresarial. Os nossos resultados apresentam uma tendência mais crítica a este nível, reforçando o argumento já avançado da importância do planeamento estratégico, designadamente a preparação da sucessão empresarial e a implementação de mecanismos de governance. O legado familiar e a forte ligação pessoal fundamentam o desejo de continuidade na transição do controlo executivo do(a) fundador(a).
Perante estes desafios e especificidades das EFs, importa que Portugal, em articulação com Comissão Europeia, promovam medidas de apoio pela disponibilização de infraestruturas eficientes em termos de custos e disseminação de informação no portal de Internacionalização de PME. A atualização de informação específica sobre EFs potenciará a capacidade de atração e fixação de empresas e talentos, bem como permite suportar programas e propostas de políticas públicas orientadas para a transformação do padrão de especialização produtivo nacional no sentido de promover condições para as EFs, tornando a economia portuguesa mais competitiva no quadro da globalização crescente.

Por tudo isto, fica o desafio de se alargar este estudo a outras regiões do país, dotando Portugal de uma base de dados nacional de empresas familiares que, em articulação com especialistas, agentes económicos e entidades oficiais competentes (e.g., INE, IES, IAPMEI), possam contribuir para a classificação e tratamentos de informação das EFs. 

Bettinelli, C.; Fayolle, A. \& Randerson, K. (2014). Family Entrepreneurship: A Developing Field. Foundations and Trends in Entrepreneurship, 10 (3), 161-236.

Block, J.H. (2012). R\&D investments in family and founder firms: An agency perspective. Journal of Business Venturing, 27(2), 248-265.

Botero, I.C., Cruz, C., De Massis, A., \& Nordqvist, M. (2015). Family business research in the European context. European Journal of International Management, 9(2), 139-159. DOI: 10.1504/EJIM.2015.067858

Bourdieu, P. [2010 (1979)]. A Distinção. Uma Crítica Social da Faculdade do Juízo. Lisboa: Edições 70.

Bourdieu, P. (1979). Les trois états du capital culturel. Actes de la Recherche en Sciences Sociales, 30 (30), 3-6.

Bryman, A., Cramer, D. (2003). Análise de Dados em Ciências Sociais. Celta: Oeiras.

Cantante, F. (2018). O Mercado de Trabalho em Portugal e nos Países Europeus: Estatísticas 2018. Lisboa: Observatório das Desigualdades (URL: https://observatoriodasdesigualdade.files.wordpress. com/2018/04/o-mercado-de-trabalho-em-portugal-e-nos-pac3adses-europeus.pdf, Acesso a 21.05.2018)

Casaca, S.F. (org.) (2012). Mudanças Laborais e Relações de Género. Coimbra: Almedina.

Comissão Europeia (2015). A nova definição de PME. Guia do utilizador e modelo de declaração. Luxemburgo: Serviço das Publicações da União Europeia (URL: http://europa.eu, Acesso a 21.05.2018)
Comissão Europeia (2008). Think Small First. Um Small Business Act para a Europa, COM(2008) 394.

Costa, A.N. (2017). Manual de Boas Práticas da Empresa Familiar. Projeto Inovafeira. DOI: 10.6084/ m9.figshare. 5545141

Costa, A.N., Rio, F.N. \& Rio, J.N. (2011). 50 Perguntas Essenciais sobre Empresas Familiares. Porto: Vida Económica.

Couto, A.I. (2013). As Pequenas e Médias Empresas e os seus Empresários: Diversidade de Contexto e de Percursos de Empreendedorismo em Portugal, Dissertação de Doutoramento em Sociologia, Lisboa, ICSTE-IUL.

Creswell, J.W. \& Clark, V.L.P. (2017). Designing and conducting mixed methods research. Los Angeles, CA: Sage Publications.

Chrisman, J.J., et al. (2010). Intellectual Foundations of Current Research in Family Business: An Identification and Review of 25 Influential Articles. Family Business Review, 23(1) 9-26

Chrisman, J.J. \& Sharma, P. \& Taggar, S. (2007). Family Influences on Firms: An Introduction. Journal of Business Research, 60. 1005-1011. 10.1016/j. jbusres.2007.02.016.

Deloitte University EMEA CVBA (2017). Next generation family businesses. Leading a family business in a disruptive environment (URL: https://www2.deloitte.com/content/dam/Deloitte/ua/Documents/ strategy/Next-generation-family-business.pdf, Acesso a 04-06-2018). 
Edelman Trust Barometer (2017). Special Report: Family Business. (URL: https://www.edelman. com/trust2017/family-business-trust, Acesso 06-03-2018).

Ernst and Young (2014). Women in leadership. The family business advantage. Special report based on a global survey of the world's largest family businesses. Ernst and Young and Kennesaw State University (URL: https://www.ey.com/Publication/vwLUAssets/ey-women-in-leadership-the-family-business-advantage/\$File/ey-women-in-leadership-the-family-business-advantage.pdf, Acesso a 07-05-2018).

KPMG (2017). European Family Business Barometer, (Sixth Edition). (URL: https://home.kpmg.com/xx/ en/home/insights/2017/11/european-family-business-barometer-confidence-in-unity-sixth-edition. html, Acesso a 23-05-2018).

KPMG (2016). European Family Business Barometer, (Fifth Edition). (URL: https://home.kpmg.com/br/ pt/home/insights/2016/10/european-family-business-barometer-2016.html, Acesso a 23-05-2018).

\section{European Commission (2009). Final report of} the expert group. Overview of the family-business-relevant issues: research, networks, policy measures and existing studies. (URL: http://ec.europa.eu/DocsRoom /documents/10388, Acesso a 04-05-2018),

Felix, S. (2017). Criação e sobrevivência de empresas em Portugal. Banco de Portugal, (URL:https://www. bportugal.pt/sites/default/files/anexos/papers/ ree201702_p.pdf, Acesso a 23-05-2018).

Fernández, Z. \& Nieto, M.J. (2005). Internationalization strategy of small and medium-sized family businesses: Some influential factors. Family Business Review, 18 (1), 77-89.
Ferreira, V. (org.) (2010). A Igualdade de Mulheres e Homens no Trabalho e no Emprego em Portugal: Políticas e Circunstâncias. Lisboa: CITE.

Gallo, M.A. \& GarcíaPont, C. (1996). Important factors in family business internationalization. Family Business Review, 9 (1), 45-59.

GEM (2013), GEM PORTUGAL 2013|2004-2013: Uma Década de Empreendedorismo em Portugal. ISCTE-IUL; SPI (URL: https://www.gemconsortium.org/country-profile/100, Acesso a 23-05-2018).

Gersick, K., et al. (1997). Generation to Generation. Life Cycles of the Family Business. Boston, Massachusetts: Harvard Business School Press.

Graves, C. \& Thomas, J. (2004). Internationalisation of the family business: A longitudinal perspective. International Journal of Globalisation and Small Business, 1(1), 7-27

Graves, C. \& Thomas, J. (2008). Determinants of the internationalization pathways of family firms: An examination of family influence. Family Business Review, 21 (2), 151-167.

Guerreiro, M.D. (1996). Famílias na actividade empresarial. PME em Portugal. Oeiras: Celta Editora.

Guerreiro, M.D. (1992). Trajectórias sociais e relações familiares. Empresários de PME. Sociologia - Problemas e Práticas, 11:63-77.

Habbershon, T.G., Williams, M.L. (1999). A Resource-Based Framework for Assessing the Strategic Advantage of Family Firms. Family Business Review, 12 (1), 1-26.

Habbershon, T.G. \& Pistrui, J. (2002). Enterprising families domain: Family-Influenced ownership 
groups in pursuit of transgenerational wealth

Family Business Review, 15(3), 223-237.

Hall, A., Melin, L. \& Nordqvist, M. (2001). Entrepreneurship as radical change in the family business: Exploring the role of cultural patterns. Family Business Review, 14(3), 193-208.

IFERA (2003). Family businesses dominate. Family Business Review, 16(4), 235-240.

Jayantilal, S. (2016). Game Theory and Family Firm Succession, Universidade de Extremadura, Tese de Doutoramento, (URL: http://dehesa.unex.es/xmlui/ handle/10662/4117, Acesso 30-04-2018).

Kim, H., Kim, H. \& Lee, P.M. (2008). Ownership structure and the relationship between financial slack and R\&D investments: Evidence from Korean firms. Organization Science, 19(3), 404-418.

Llach, J. \& Nordqvist, M. (2010). Innovation in family and non-family businesses: A resource perspective. International Journal of Entrepreneurial Venturing, 2(3), 381-399.

Leandro, E. (2001). Sociologia da família nas sociedades contemporâneas. Lisboa: Universidade Aberta.

Lisboa, M. (2002). A indústria portuguesa e os seus dirigentes: crescimento na segunda metade do século $\mathrm{XX}$ e potencial de inovação das funções capitalista, empresarial e de gestão. Lisboa: Educa.

Litz, R.A. (2008). Two sides of a one-sided phenomenon: Conceptualizing the family business and business family as a Mobius Strip. Family Business Review, 21(3), 217-236.

Marques, A.P. (2013). Reestruturação produtiva e recomposições do trabalho e emprego: um périplo pelas "novas" formas de desigualdade social. Ciênc. saúde coletiva, vol.18, n.6, pp. 1545-1554. ISSN 1413-8123.

Marques, A.P. (2010). 'Sacralização' do mercado de trabalho. Jovens diplomados sob o signo da precariedade. Revista Configurações, $\mathrm{n}^{\circ} 7$, CICS, Universidade do Minho, 65-89.

Morgan, G. (1996). Imagens da organização. São Paulo: Atlas.

Munari, F., Oriani, R. \& Sobrero, M. (2010). The effects of owner identity and external governance systems on R\&D investments: A study of Western European firms. Research Policy, 39(8), 1093-1104.

Naldi, L., et al. (2007). Entrepreneurial orientation, risk taking, and performance in family firms. Family Business Review, 20(1), 33-47.

Observatório InSight (2018). Segundo inquérito InSight Um olhar sobre a internacionalização das $P M E$. Câmara do Comércio e Indústria Portuguesa e E-Monitor (URL: http://www.ccip.pt/images/documentos/InSight2018.pdf, Acesso a 24-05-2018).

Pestana, M., Gageiro, J. (1998). Análise de dados para ciências sociais - A complementaridade do SPSS. Lisboa: Edições Sílabo.

Rodrigues, J. (2017). Família empresária e competências empreendedoras. Fórum Sociológico, Online, N. 29 (II Série, 2016), 53-63 (URL: http://journals. openedition.org/sociologico/1497; DOI: 10.4000/ sociologico.1497, Acesso a 16-06-2018).

Rosa, M.J.V.; Paulo, C. (2010). Portugal: os números. Lisboa: Fundação Francisco Manuel dos Santos.

Russell-Reynolds Associates (2014). Prácticas de Gobierno Corporativo en la Empresa Familiar en Europa, IESE, Cátedra Empresa Familiar (URL: https:// 
Bibliografica - Roadmap para Empresas Familiares Portuguesas

www.iese.edu/es/files/15\%2001\%2009\%20def\%20 practicas\%20gobierno1_tcm5-114093.pdf, Acesso 16-06-2018).

Sharma, P. \& Manikutty, S. (2005). Strategic divestments in family firms: role of family structure and community culture. Entrepreneurship Theory and Practice, 29 (3), 293-311.

Sundaramurthy, C. \& Kreiner, G.E. (2008). Governing by managing identity boundaries: The case of family businesses. Entrepreneurship Theory and Practice, 32 (3), 415-436.

Tagiuri, R. \& Davis, J. (1982). Bivalent attributes of the family business. Working Paper, Cambridge, Massachusetts, Harvard Business School (Reprinted 1996, Family Business Review, IX (2), 199-208).
Tagiuri, R. \& Davis, J. (1992). On the goals of successful family companies. Family Business Review, 5(1), 43-62.

Tesch, R. (2013). Qualitative research: Analysis types and software. London: Routledge.

Torres, A.C. (2002). Casamento em Portugal. Uma Análise Sociológica. Oeiras: Celta Editora.

Wall, K. (2005). Famílias em Portugal. Percursos, interacções, redes sociais. Lisboa: Imprensa das Ciências Sociais.

Werner, A., Schröder, C.S. \& Chlosta, S. (2018). Driving factors of innovation in family and non-family SMEs. Small Business Economics, 50(3), 201-218. 

